Prepared in cooperation with the CITY OF OKLAHOMA CITY

\title{
Statistical Analysis of Stream Water- Quality Data and Sampling Network Design near Oklahoma City, Central Oklahoma, 1977-1999
}

Water-Resources Investigations Report 02-4111

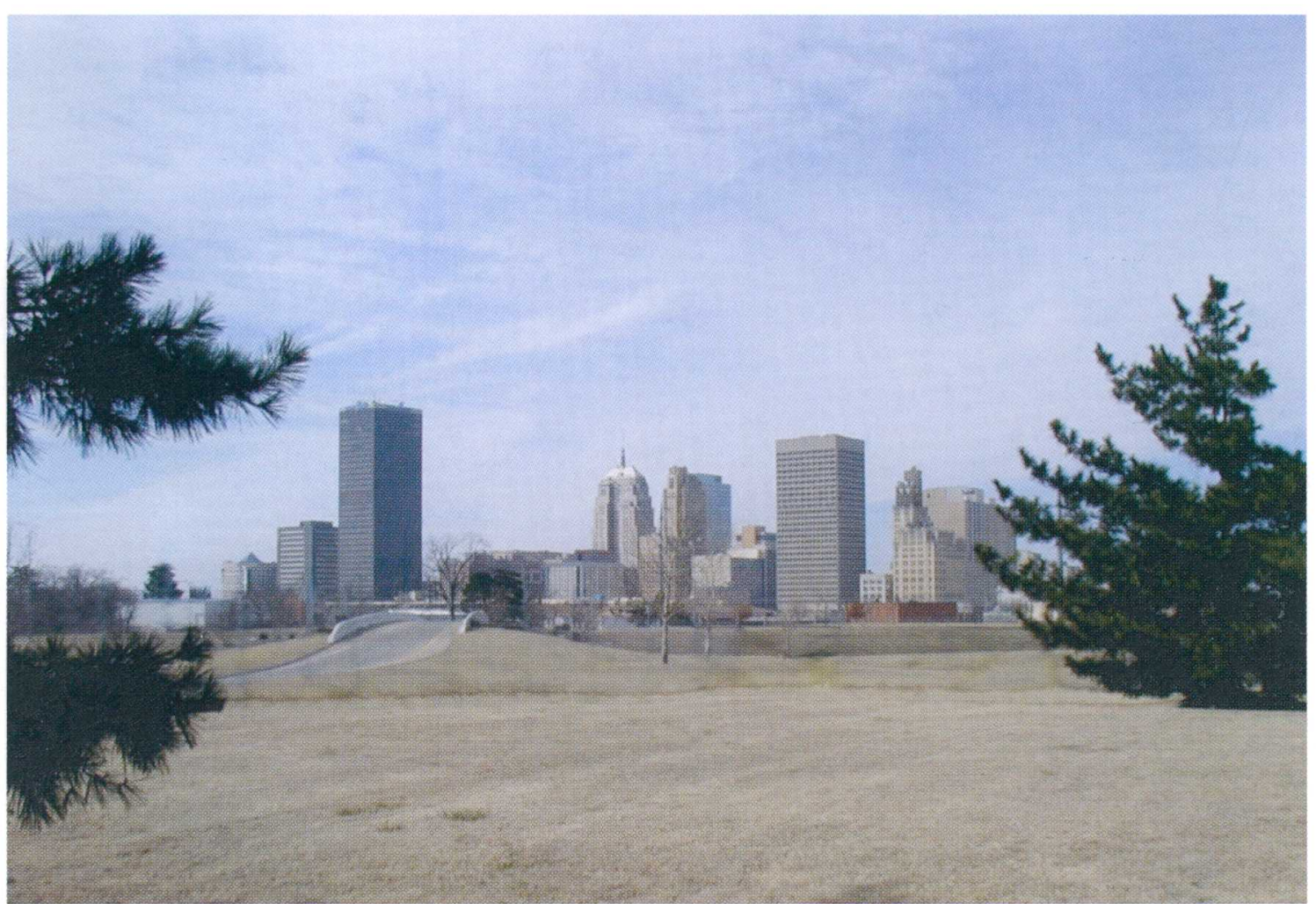


On cover: Photograph of Oklahoma City skyline taken by William J. Andrews 


\section{Statistical Analysis of Stream Water- Quality Data and Sampling Network Design near Oklahoma City, Central Oklahoma, 1977-1999}

By Mark E. Brigham, Gregory A. Payne, William J. Andrews, and Marvin M. Abbott

Water-Resources Investigations Report 02-4111

Prepared in cooperation with the CITY OF OKLAHOMA CITY 


\section{U.S. Department of the Interior \\ GALE A. NORTON, Secretary}

\section{U.S. Geological Survey}

CHARLES G. GROAT, Director

The use of firm, trade, and brand names in this report is for identification purposes only and does not constitute endorsement by the U.S. Geological Survey.

UNITED STATES GOVERNMENT PRINTING OFFICE: OKLAHOMA CITY 2002

For additional information write to:

District Chief

U.S. Geological Survey

Water-Resources Division

202 NW 66 St., Bldg. 7

Oklahoma City, OK 73116
Copies of this report can be purchased from:

U.S. Geological Survey

Information Services

Box 25286

Federal Center

Denver, CO 80225

Additional information about water resources in Oklahoma is available on the World Wide Web at http://ok.water.usgs.gov 


\section{CONTENTS}

Abstract

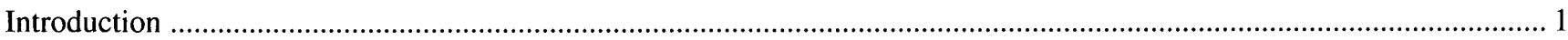

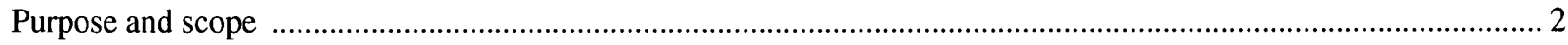

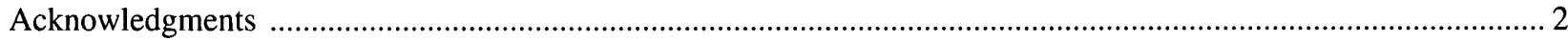

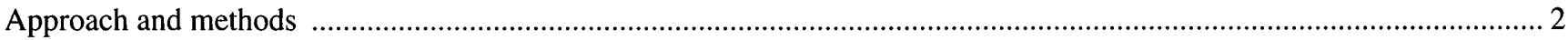

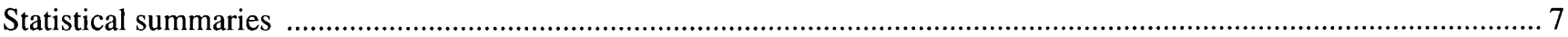

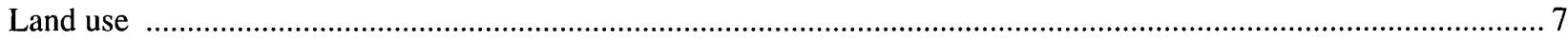

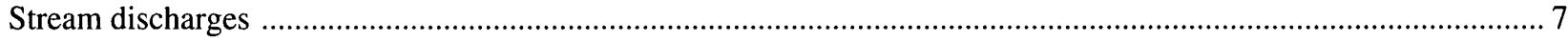

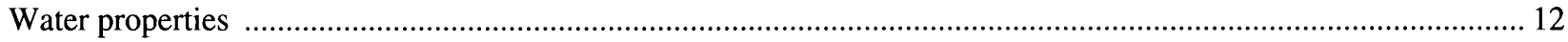

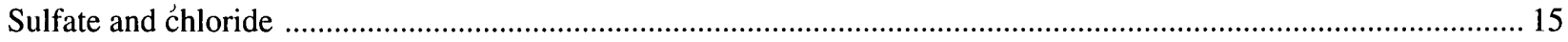

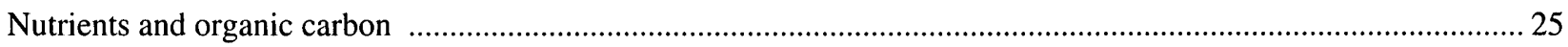

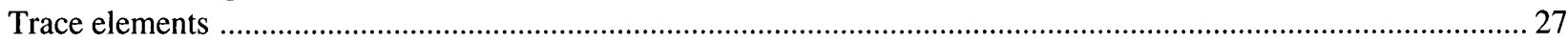

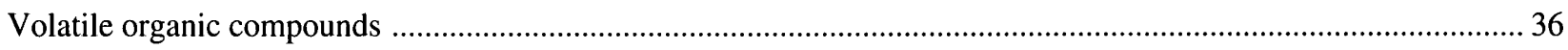

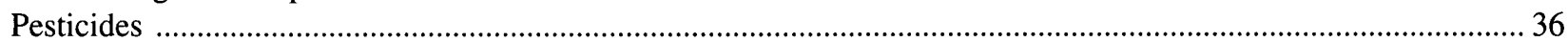

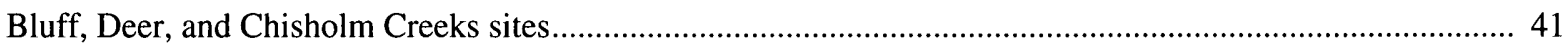

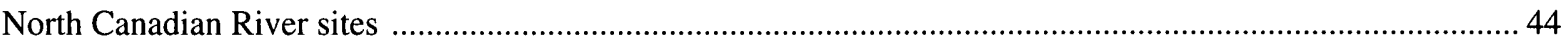

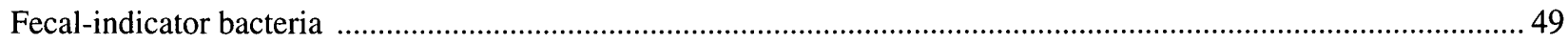

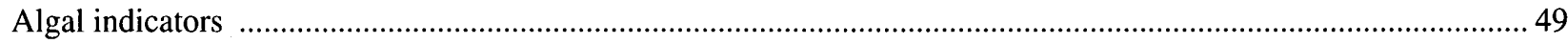

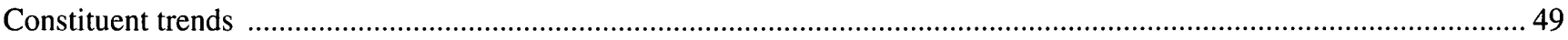

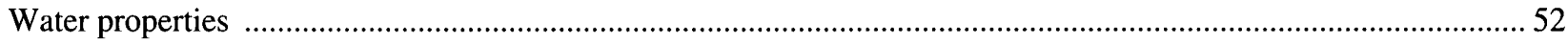

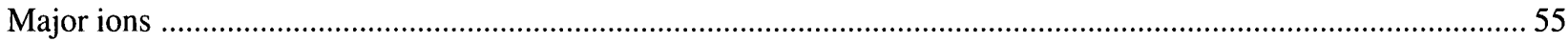

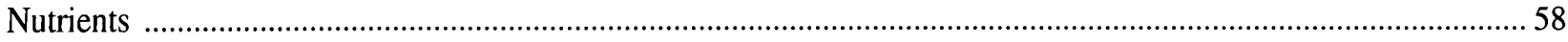

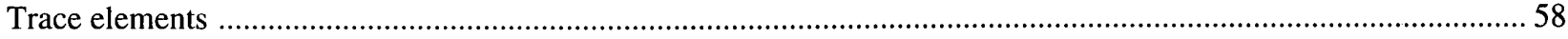

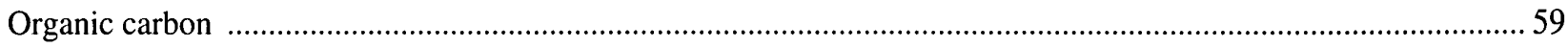

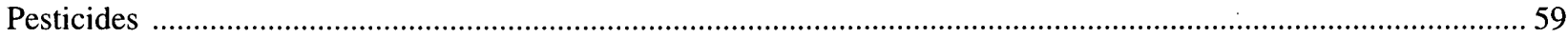

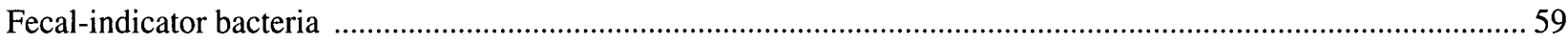

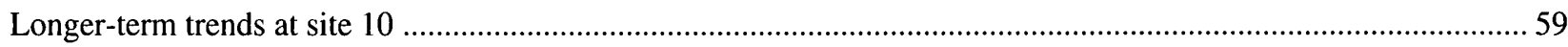

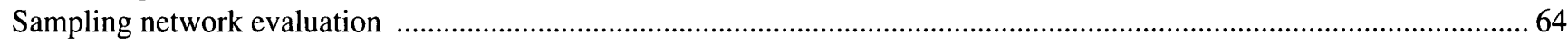

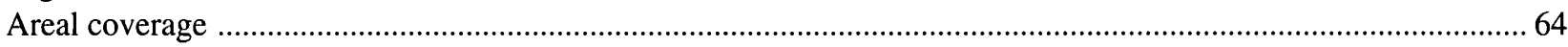

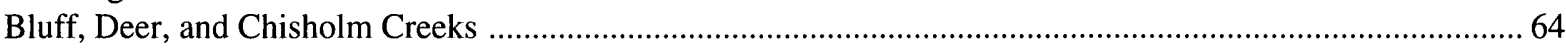

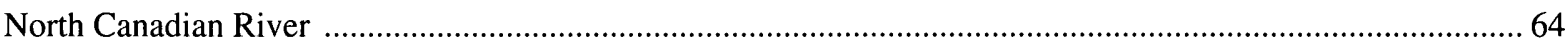

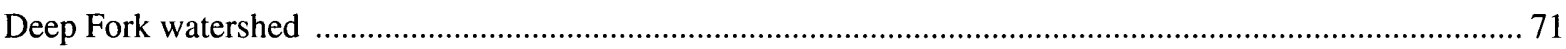

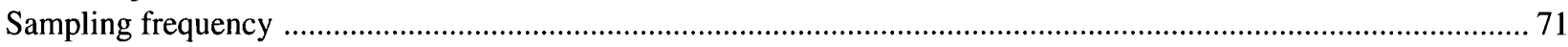

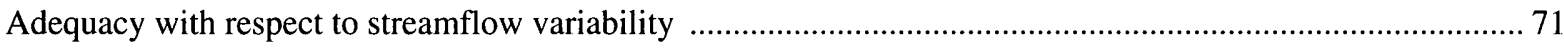

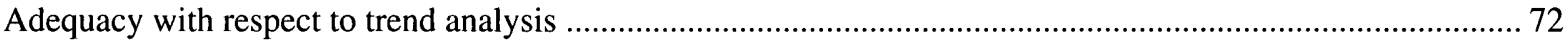

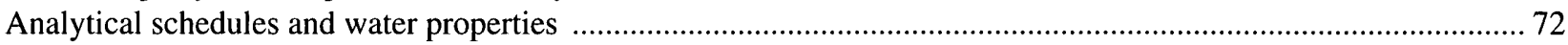

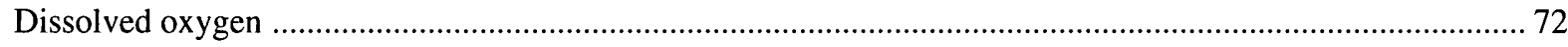

pH

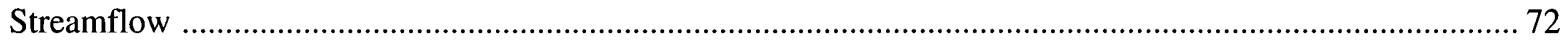

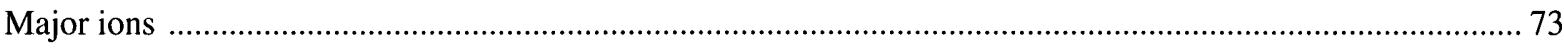

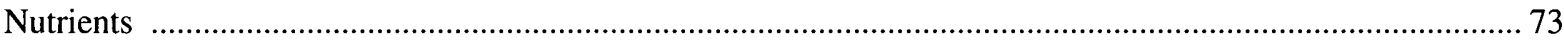

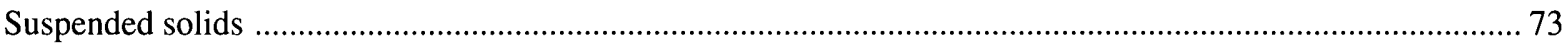

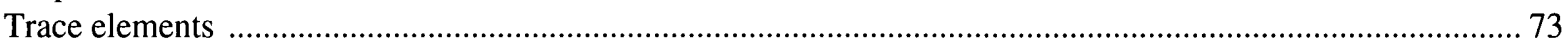

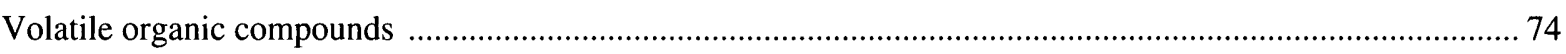

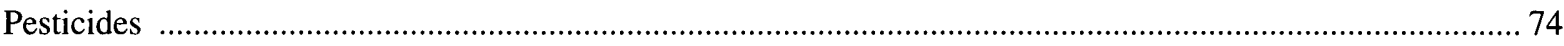

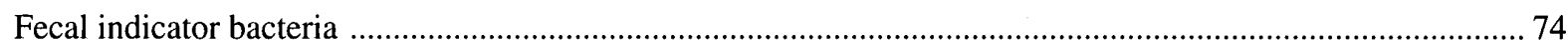

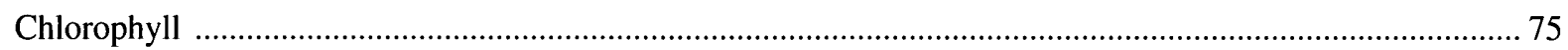

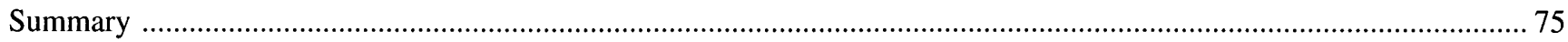

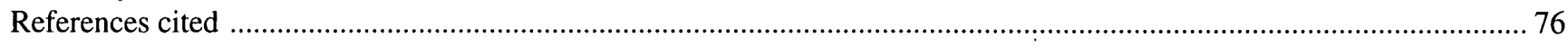

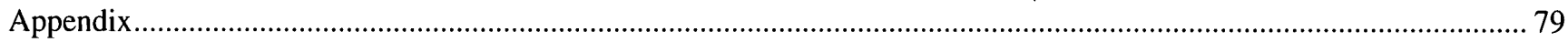

1. Summary statistics of water-quality data from sites on Bluff, Deer, and Chisholm Creeks in central 
Oklahoma, 1993-99

2. Summary statistics of water-quality data from sites on the North Canadian River in central

Oklahoma, 1988-99.

3. Regressions of water-quality data with stream discharge, time, and season for sites on the North

Canadian River in central Oklahoma, 1988-99.

\section{ILLUSTRATIONS}

Figures 1-2. Maps showing:

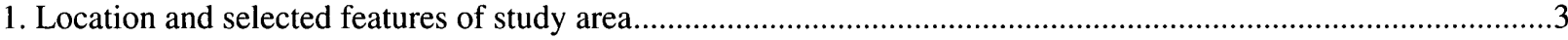

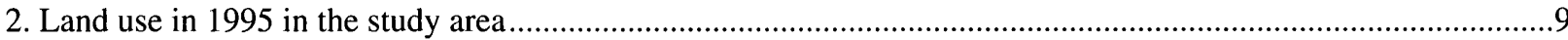

Figures 3-49. Graphs showing:

3. Mean monthly streamflows at stations on the North Canadian River near Oklahoma City, October 1988-September 1999

4. a) Flow exceedance for continuous and instantaneous data at selected sites on the North Canadian

River, and b) instantaneous discharge measured quarterly at selected sites on Bluff, Deer, and

Chisholm Creeks (1993-99) and measured quarterly, monthly, and daily on the North Canadian

River (1988-99).

5. Specific conductance for selected sites on Bluff, Deer, and Chisholm Creeks (1993-99) and the

North Canadian River (1988-99) .............................................................................................................

6. Dissolved solids concentration for selected sites on the North Canadian River, 1988-99 ................................14

7. Dissolved oxygen concentrations for selected sites on Bluff, Deer, and Chisholm Creeks (1993-99)

and the North Canadian River (1988-99)

8. Continuous dissolved oxygen concentrations measured at North Canadian River near Harrah

(site 10), August 2000

9. Dissolved oxygen concentrations, in percent of saturation, for selected sites on Bluff, Deer, and

Chisholm Creeks (1993-99) and the North Canadian River (1988-99) ..........................................................18

10. Carbon dioxide concentration for selected sites on the North Canadian River, 1988-99.................................19

11. Five-day biochemical oxygen demand for selected sites on the North Canadian River, 1988-99 .....................20

12. Turbidity for selected sites on the North Canadian River, 1988-99 …..........................................................21

13. Turbidity and discharge measured at North Canadian River near Harrah (site 10), 1988-99 ...........................22

14. Sulfate concentration for selected sites on the North Canadian River, 1988-99 .............................................23

15. Chloride concentration for selected sites on the North Canadian River, 1988-99 …........................................24

16. Nitrite-nitrogen concentration for selected sites on the North Canadian River, 1988-99 ................................26

17. Nitrite plus nitrate-nitrogen concentration for selected sites on the North Canadian

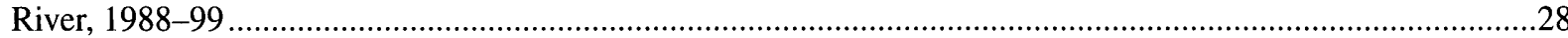

18. Ammonia-nitrogen concentration for selected sites on the North Canadian River, 1988-99..........................29

19. Organic nitrogen concentration for selected sites on the North Canadian River, 1988-99 ..............................30

20. Organic plus ammonia-nitrogen concentration for selected sites on the North Canadian

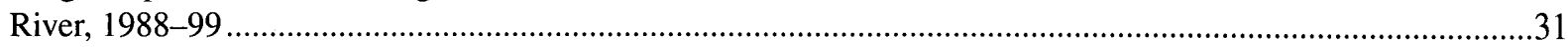

21. Sum of dissolved nitrogen compound concentration for selected sites on the North Canadian

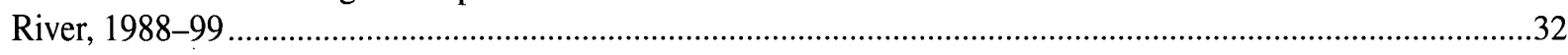

22. Dissolved phosphorus concentrations for selected sites on the North Canadian River, 1988-99....

23. Orthophosphate-phosphorus concentration for selected sites on the North Canadian

River, 1988-99.

24. Dissolved organic carbon concentration for selected sites on the North Canadian River, 1988-99......

25. Manganese concentration for selected sites on the North Canadian River, 1988-99 .......................................37

26. Annual use of the 10 most commonly applied pesticides for cropland in Logan, Canadian, and Oklahoma Counties, Oklahoma, in 1989

27. Frequency of detection of pesticides for selected sites on Bluff, Deer, and Chisholm

Creeks, 1993-99 
28. Frequency of detection of pesticides for selected sites on the North Canadian River, 1988-99

29. Chlorpyrifos concentration for selected sites on Bluff, Deer, and Chisholm Creeks (1993-99),

and the North Canadian River (988-99).

30. Diazinon concentration for selected sites on Bluff, Deer, and Chisholm Creeks (1993-99) and the North Canadian River (1988-99).

31. 2,4-D concentration for selected sites on the North Canadian River, 1988-99

32. Atrazine concentration for selected sites on the North Canadian River, 1988-99

33. Lindane concentration for selected sites on the North Canadian River, 1988-99.

34. Fecal coliform bacteria count for selected sites on the North Canadian River, 1988-99

35. Chlorophyll- $a$ in relation to temperature and time and Carlson's Trophic Index for chlorophyll- $a$ in relation to time for North Canadian River near Harrah (site 10), 1988-96.

36. Specific conductance in relation to stream discharge for North Canadian River near Harrah (site 10, 1988-99

37. Dissolved oxygen concentration in relation to stream discharge for North Canadian River near

Harrah (site 10), 1988-99.

38. Sulfate concentration in relation to instantaneous stream discharge and time for North Canadian

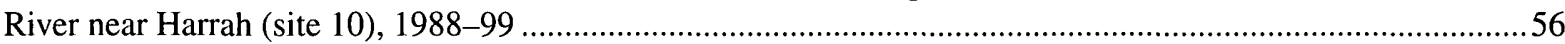

39. Chloride concentration in relation to time for selected sites on the North Canadian

River, 1988--99

40. Dieldrin concentration in relation to time for North Canadian River near Harrah, Oklahoma (site 10), 1988-99

41. Lindane concentration in relation to time for North Canadian River near Harrah,

Oklahoma (site 10), 1988-99

42. Fecal coliform bacteria count in relation to stream discharge for selected sites on the North

Canadian River, 1988-99

43. Specific conductance in relation to time for North Canadian River near Harrah, Oklahoma (site 10), 1977-99.63

44. Biochemical oxygen demand in relation to time for North Canadian River near Harrah, Oklahoma (site 10), 1977--99

45. Carbon dioxide concentration in relation to time for North Canadian River near Harrah,

Oklahoma (site 10), 1977-99

46. Chloride concentration in relation to time for North Canadian River near Harrah, Oklahoma (site 10), 1977-99

47. Ammonia-nitrogen concentration in relation to time for North Canadian River near Harrah,

Oklahoma (site 10), 1979-99

48. Orthophosphate-phosphorus concentration in relation to time for North Canadian River near

Harrah, Oklahoma (site 10), 1979-99.

49. Fecal coliform bacteria count in relation to time for North Canadian River near Harrah, Oklahoma

(site 10), 1977-99.

\section{TABLES}

1. Properties measured continuously at sites on the North Canadian River since 1988 4

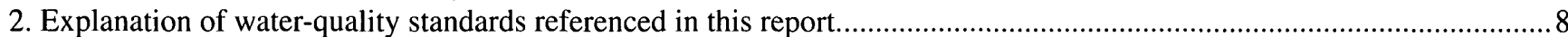

3. Drainage areas and flow characteristics for the sites on the North Canadian River.......................................................12

4. Number of samples collected and median concentrations of nutrients in the Mississippi River and its tributaries and undeveloped basins in the United States

5. Trends in mean monthly streamflow at sites on the North Canadian River near Oklahoma City,

Oklahoma, 1988-99 


\section{CONVERSION FACTORS AND VERTICAL DATUM}

\begin{tabular}{rll}
\hline Multiply & By & To obtain \\
\hline \multicolumn{3}{c}{ Length } \\
\hline foot (ft) & 0.3048 & meter \\
mile (mi) & 1.609 & kilometer \\
\hline \multicolumn{3}{c}{ Area } \\
\hline square mile ( $\left.\mathrm{mi}^{2}\right)$ & 2.590 & square kilometer \\
\hline gallon (gal) & Volume \\
\hline & 3.785 & liter \\
\hline & Flow rate \\
\hline foot per day (ft/d) & 0.3048 & meter per day \\
\hline
\end{tabular}

Temperature in degrees Celsius $\left({ }^{\circ} \mathrm{C}\right)$ may be converted to degrees Fahrenheit $\left({ }^{\circ} \mathrm{F}\right)$ as follows:

${ }^{\circ} \mathrm{F}=1.8^{\circ} \mathrm{C}+32$

Temperature in degrees Fahrenheit $\left({ }^{\circ} \mathrm{F}\right)$ may be converted to degrees Celsius $\left({ }^{\circ} \mathrm{C}\right)$ as follows:

$$
{ }^{\circ} \mathrm{C}=\left({ }^{\circ} \mathrm{F}-32\right) / 1.8
$$

Sea level: In this report, "sea level" refers to the National Geodetic Vertical Datum of 1929 (NGVD of 1929)-a geodetic datum derived from a general adjustment of the first-order level nets of both the United States and Canada, formerly called Sea Level Datum of 1929.

Specific conductance is given in microsiemens per centimeter at 25 degrees Celsius $\left(\mu \mathrm{S} / \mathrm{cm}\right.$ at $\left.25^{\circ} \mathrm{C}\right)$.

Concentrations of chemical constituents in water are given either in milligrams per liter (mg/L) or micrograms per liter $(\mu \mathrm{g} / \mathrm{L})$.

Water Year: October 1 to September 30, with the year denoted by the year starting on January 1 . 


\title{
Statistical Analysis of Stream Water-Quality Data and Sampling Network Design near Oklahoma City, Central Oklahoma, 1977-1999
}

\author{
By M.E. Brigham, G.A. Payne, W.J. Andrews, and M.M. Abbott
}

\section{ABSTRACT}

Water-quality data collected from 1993-99 at five sites on Bluff, Deer, and Chisholm Creeks and from 1988-99 at five sites in the North Canadian River indicated that there were significant differences in constituent values among sites for water properties, major ions, trace elements, nutrients, turbidity, pesticides, and bacteria. Concentrations of dissolved solids and sulfate generally decreased as streams flowed through the Oklahoma City urban area. Concentrations of organic carbon, nitrogen and phosphorus compounds, lindane, and 2,4-D, and frequencies of detection of pesticides increased in the North Canadian River as it flowed through the urban area. Volatile organic compounds were not detected in samples collected quarterly from 1988-90 at sites on the North Canadian River. Concentrations of some compounds, including dissolved oxygen, sulfate, chloride, ammonia, manganese, diazinon, dieldrin, and fecal . coliform bacteria periodically exceeded Federal or state water-quality standards at some sites.

Regression analyses were used to identify trends in constituent concentrations related to streamflow, season, and time. Trends for some constituents were indicated at all sites, but most trends were sitespecific. Seasonal trends were evident for several constituents: suspended solids, organic nitrogen, and biochemical oxygen demand were greatest during summer. Dissolved oxygen, ammonia, and nitrite plus nitrate-nitrogen were greatest during winter. Concentrations of dissolved oxygen, fluoride, sulfate, total suspended solids, iron, and manganese generally increased with time. Concentrations of chloride, nitrite plus nitrate-nitrogen, dissolved phosphorus, dissolved orthophosphate, biochemical oxygen demand, dieldrin, and lindane decreased with time. There was relatively little change in land use from the late 1970s to the mid-1990s due to relatively modest rates of population growth in the study area during that period. Most changes in water quality in these streams and rivers may be due to changes in chemical use and wastewater treatment practices.

The sampling network was evaluated with respect to areal coverage, sampling frequency, and analytical schedules. Areal coverage could be expanded to include one additional watershed that is not part of the current network. A new sampling site on the North Canadian River might be useful because of expanding urbanization west of the city, but sampling at some other sites could be discontinued or reduced based on comparisons of data between the sites. Additional real-time or periodic monitoring for dissolved oxygen may be useful to prevent anoxic conditions in pools behind new low-water dams. The sampling schedules, both monthly and quarterly; are adequate to evaluate trends, but additional sampling during flow extremes may be needed to quantify loads and evaluate water-quality during flow extremes. Emerging water-quality issues may require sampling for volatile organic compounds, sulfide, total phosphorus, chlorophyll- $a$, Esherichia coli, and enterococci, as well as use of more sensitive laboratory analytical methods for determination of cadmium, mercury, lead, and silver.

\section{INTRODUCTION}

The U.S. Geological Survey, in cooperation with the City of Oklahoma City, has periodically sampled water at five sites on Bluff, Deer, and Chisholm Creeks since 1993 for selected water properties and pesticides to determine the occurrence of selected pesticides in water flowing from an urban basin in the city toward the Cimarron River (located 
about 6 miles north of the study area shown on fig. 1). Five sites on the North Canadian River have been periodically sampled since 1977 for water properties, major ions, nutrients, pesticides, and bacteria to determine the quality of water used as the primary drinking-water supply for the city and some surrounding communities and to determine the effects of city wastewater discharges and urban land uses on water quality downstream.

This work is being done by USGS to provide information to better define and manage the quality of the Nation's water resources. Aspects of that goal addressed by this sampling program include: providing quantitative understanding of the sources of nutrients entering streams, determining the effects of land use practices on surface and ground-water quality, contributing understanding of relations between water quality and health of stream ecosystems, providing information useful in setting Total Maximum Daily Load requirements of the Clean Water Act, and increasing the availability of waterquality information, including real-time data, for rivers near the Nation's largest cities, as described in Hirsch (2000).

\section{Purpose and Scope}

This report summarizes water-quality data collected in cooperation with the City of Oklahoma City by the U.S. Geological Survey (USGS) from Bluff, Deer, and Chisholm Creeks from 1993-99 and from the North Canadian River from 1988-99 and evaluates the sampling program. Trends in selected constituents in the North Canadian River since 1977 also are described. This report presents: (1) statistical summaries of selected constituent concentrations, (2) descriptions of similarities and differences in constituent concentrations between sites, (3) descriptions of the occurrence of pesticides in surface water and pesticide use on cropland in the area, (4) comparisons to Federal and State water-quality standards, (5) descriptions of trends with time of constituent concentrations and streamflow, (6) descriptions of land uses and possible sources of contaminants in the basins above the sites, and (8) an evaluation of the sampling network.

This report contains summary statistical tables and graphs of water-quality data collected at sites on Bluff, Deer, and Chisholm Creeks from 1993-99 and from the North Canadian River from 1988-99 (Appendices 1 and 2). Trend analyses of water-quality from sites on the North Canadian River were made using multivariate regression equations which account for streamflow and seasonality. Correctness of fits of models were tested to determine if the regression models are "good," "fair," or "poor." Last, an evaluation was made of the suitability of the current stations, sampling plans, and sampled analytes.

Continuous monitors have recorded specific conductance, temperature, and dissolved oxygen concentration since the late 1980s at selected sites on the North Canadian River (table 1), but those data are not summarized in detail in this report due to concerns about serial correlation affecting trend analyses.

\section{Acknowledgments}

The authors thank Dave Lorenz, U.S. Geological Survey, for statistical advice, and for assistance with interpretation of seasonal coefficients in regression models included in this report. Carol Becker, U.S. Geological Survey, provided data regarding pesticide use in the study area.

\section{APPROACH AND METHODS}

Streamflow and water-quality data were retrieved from the U.S. Geological Survey National Water Information System for Oklahoma. Data were screened to remove stream cross-sectional data, such as cross-sectional measurements of field parameters, leaving analyses of 1,426 water samples collected at the sites. Sample coding indicated that 1,195 of those samples were collected by the U.S. Geological Survey (231 did not have sampling agency specified); 1,183 of the samples were analyzed by the U.S. Geological Survey National Water Quality Laboratory, in Arvada (now Lakewood), Colorado. Thus, most samples were collected by U.S. Geological Survey personnel and analyzed at the National Water Quality Laboratory.

Because of the relatively limited water-quality data collected at site number 7 (North Canadian River near El Reno, Oklahoma), instantaneous data are listed in Appendix 2, but data from that site are not otherwise summarized or compared to data from the other 


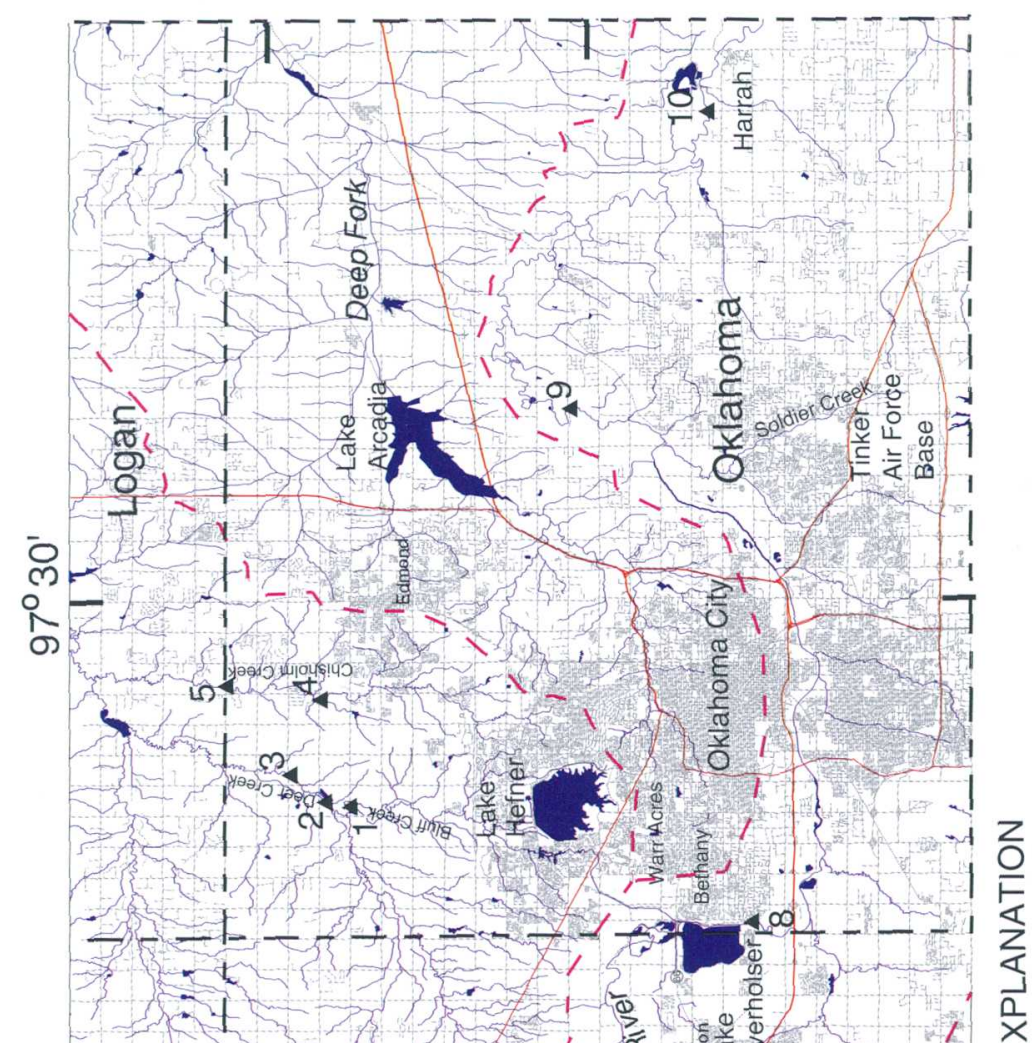

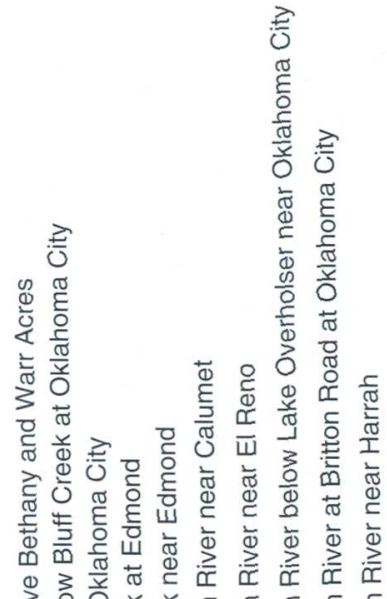

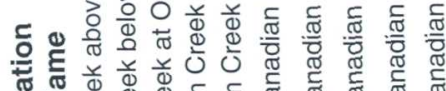

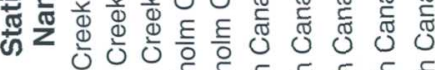
志市 ะ क्विणzzzzz

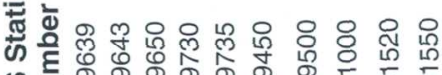
근

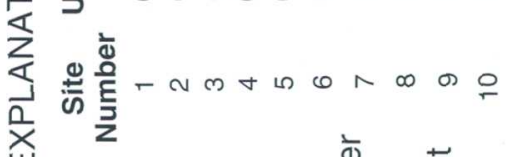

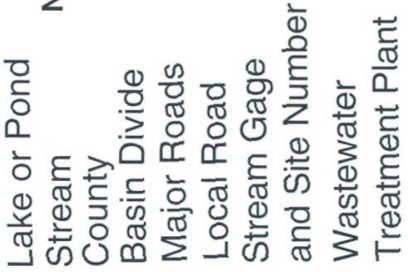

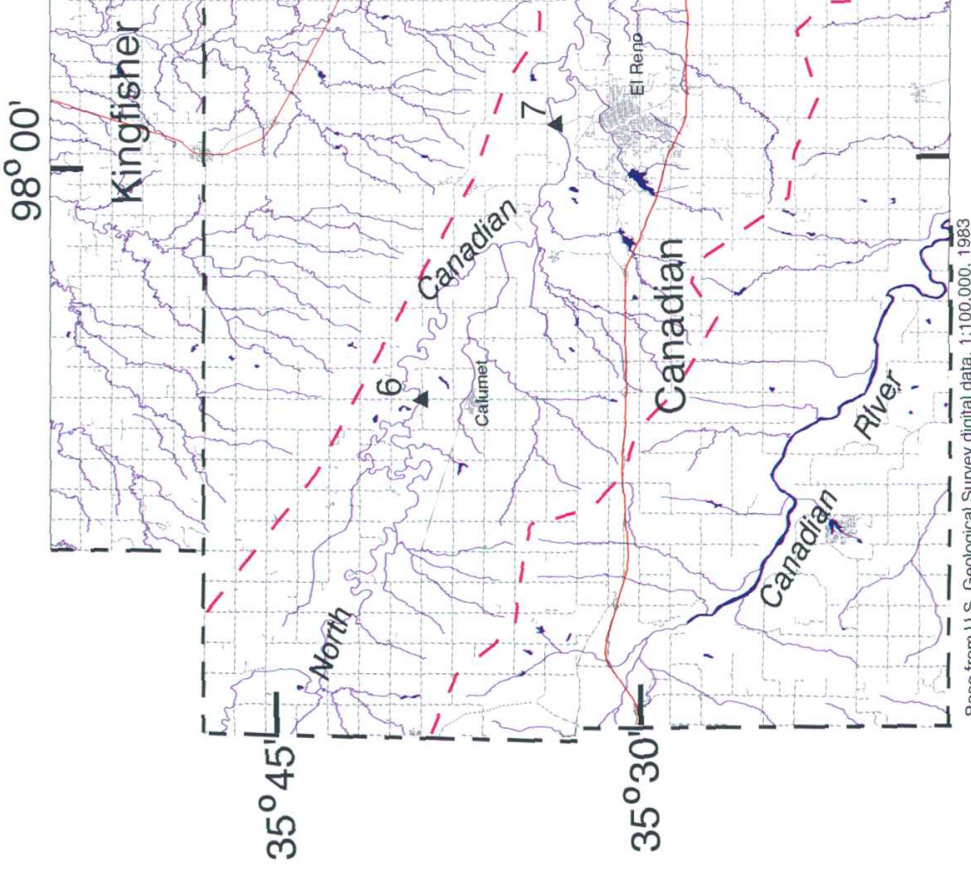

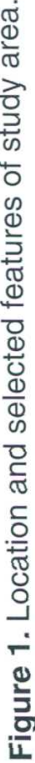


Table 1. Properties measured continuously at sites on the North Canadian River since 1988

[X, parameter measured; --, parameter not measured]

\begin{tabular}{clcccc}
\hline $\begin{array}{c}\text { Site } \\
\text { Number }\end{array}$ & \multicolumn{1}{c}{ Station Name } & $\begin{array}{c}\text { Specific } \\
\text { conduc- } \\
\text { tance }\end{array}$ & pH & Temperature & $\begin{array}{c}\text { Dissolv } \\
\text { ed } \\
\text { oxygen }\end{array}$ \\
\hline 6 & North Canadian River near Calumet, OK & $\mathrm{X}$ & $\mathrm{X}$ & $\mathrm{X}$ & $\mathrm{X}$ \\
7 & North Canadian River near El Reno, OK & $\mathrm{X}$ & -- & $\mathrm{X}$ & -- \\
8 & $\begin{array}{c}\text { North Canadian River below Lake Overholser } \\
\text { near Oklahoma City, OK }\end{array}$ & $\mathrm{X}$ & -- & $\mathrm{X}$ & $\mathrm{X}$ \\
9 & $\begin{array}{c}\text { North Canadian River at Britton Road at Okla- } \\
\text { homa City, OK }\end{array}$ & $\mathrm{X}$ & -- & $\mathrm{X}$ \\
10 & North Canadian River near Harrah, OK & $\mathrm{X}$ & $\mathrm{X}$ & $\mathrm{X}$ & $\mathrm{X}$ \\
\hline
\end{tabular}

sites on the North Canadian River and trend analyses were not attempted for those limited data.

Specific conductance and dissolved oxygen concentrations recorded by continuous monitors at sites $6,8,9$, and 10 on the North Canadian River are shown as box plots for comparison with instantaneous data collected at those sites. Those data are not otherwise summarized in this report. Trend analyses were not attempted for those data due to concerns about serial correlation of those data.

Concentrations too low to be quantified typically are reported as less than a method reporting limit, where the method reporting limit is the lowest concentration that can be reliably quantified. Review of the data revealed that many constituents had more than one method reporting limit. For those cases, data were censored to the greatest method reporting limit. In a few cases, anomalously high method reporting limits (10 to 100 times greater than typical method reporting . limits) were ignored, and the values were censored at the common method reporting limit.

Data censored according to these guidelines were used for statistical summaries. Results of statistical tests are described as significant if the resultant $\mathrm{p}$ - value (attained significance level) is less than $\alpha, \alpha$ being the critical significance level $(0.05$ in this report). If $\alpha$ equals 0.05 , spurious significant results will be obtained in about 5 percent of statistical tests. For regression results, Student's t-tests of the coefficients of each independent variable were used to indicate whether coefficients of trends were significantly different from zero. Locally-weighted estimated scatterplot smoothing (LOWESS; Cleveland and McGill, 1984, Cleveland, 1985) is used to illustrate constituent trends in several illustrations in this report.

Streamflow and seasonal conditions frequently affect water quality and should be accounted for when evaluating temporal trends (Helsel and Hirsch, 1992, p. 224-345). Parametric, sinusoidal regression analyses (Brigham and Payne, 1999) were conducted for determination of significant trends of data variables. Those trends are not intended to be predictive.

Water quality can be affected substantially by streamflow and by climatic cycles (wet versus dry periods). An apparent change in water quality during a time period may indicate responses to climatic cycles rather than indicating effects of human activities in a watershed. Determination of time trends in streamflow 
is therefore useful prior to analyzing surface-waterquality data for temporal trends.

To evaluate the relation of constituent concentrations to streamflow, season, and time, the following regression equations were used:

$$
\text { conc. }=A+B \log _{10}(\mathrm{Q})+C \sin (2 \pi \mathrm{t})+D \cos (2 \pi \mathrm{t})+E \mathrm{t}
$$

and

$\log _{10}($ conc. $)=A+B \log _{10}(\mathrm{Q})+C \sin (2 \pi \mathrm{t})+D \cos (2 \pi \mathrm{t})+$ Et

where conc. is the constituent concentration in milligrams or micrograms per liter;

$A$ is the intercept;

$B$ is the regression coefficient for streamflow;

$C$ is the regression coefficient for the sine term for seasonal trend;

$D$ is the regression coefficient for the cosine term for seasonal trend; time;

$E$ is the regression coefficient for change with

$\log _{10}$ is the base-10 logarithm;

$\mathrm{Q}$ is streamflow, in cubic feet per second;

sin and cos are sine and cosine (trigonometric functions);

$\pi$ is 3.14159 ; and

$\mathrm{t}$ is time, in years, since January 1,1960 , for example, July 1,1980 has a value of $\mathrm{t}=20.50$.

The significance of regression coefficients can be affected by outlying values. The effect of outliers was eliminated by conducting an initial analysis and then including in subsequent analyses only those observations for which the absolute value of the Student's test residuals was less than $2 . \dot{5}$. Regression coefficients with time (E) for $\log _{10}$-transformed constituents (Appendix 3) can be expressed as trend slopes in percentages per year over the period of record by use of the following equation:

$\left(10^{\mathrm{x}}-1\right) 100$

in which " $\mathrm{x}$ " is the $\log _{10}$-transformed trend coefficient. To calculate trend slopes in original units per year for transformed coefficients, the following equation may be applied to $\log _{10}$-transformed trend regression coefficients:

(10x-1)median value.

The untransformed " $E$ " coefficient for trends with time in Appendix 3 is given in measured units of the constituents (typically milligrams per liter per year).
Those coefficient values can be converted to percentages of the median value with time by division by the median value for the constituent and multiplication by 100 percent.

Regression coefficients significantly different from zero ( $p$-values less than 0.05 ) indicate a significant relation between a constituent concentration and the regression coefficient. Significant positive values of the letter coefficients in equations 1 and 2 indicate that a constituent concentration increases as streamflow increases (B) or as time increases (E), and significant negative relations indicate the constituent concentration decreases as streamflow increases (B) or as time increases (E). Significant relations ( $p$-values less than 0.05 ) for the sine term (C), the cosine term (D), or both terms indicate significant seasonality of trends. Equations 1 and 2 are essentially equivalent to a "simple sinusoidal model" (Chatfield, 1980, equation 7.1, p. 128), except that equations 1 and 2 also account for streamflow and time. This model, with a periodicity of one year $(2 \pi \mathrm{t}$, where $t$ is years), describes cyclic variations on annual time scales. The trigonometric coefficients can be re-expressed according to equation 3 (after Chatfield, 1980, equation 7.11, p. 128):

$$
C \sin 2 \pi \mathrm{t}+D \sin 2 \pi \mathrm{t}=R_{p} \cos \left(2 \pi \mathrm{t}+\phi_{p}\right)
$$

where $R_{p}$ is defined as the amplitude of the $p^{\text {th }}$ harmonic, which is interpreted as the magnitude of the peak, for this report the magnitude by which modeled annual peak concentrations exceed mean concentrations. $R_{p}$, or magnitude, is obtained from equation 4 (after equation 7.12, Chatfield, 1980, p. 134):

$$
R_{p}=\text { Magnitude }=\left(C^{2}+D^{2}\right)^{0.5}
$$

where $C$ and $D$ are defined in equations 1 and 2. Similarly, annual minimums in modeled concentrations will be less than mean concentrations by this same magnitude. phase as:

$$
\text { Chatfield (1980, equation 7.13, p. 134) defines }
$$

$$
\phi_{p}=\text { phase }=\tan ^{-1}(-C / D)
$$

where $\tan ^{-1}$ is the trigonometric arctangent function. The timing of the annual peak modeled in equations 1 and 2 can be determined by re-expressing the phase, and 
scaling to useful time scales-months in this report. If a unit circle ( $2 \pi$ radians) represents an annual cycle, 12 months, then to scale the phase to months, we multiply phase by ( 12 months $) /(2 \pi$ radians $)$, or $6 / \pi$. The cyclic nature of the phase calculation requires that the result based on the domains of $C$ and $D$ be modified, such that correct peak months are obtained (equations 6-8):

$$
\begin{aligned}
& \text { if }\{C>0 \text { and } D>0\} \text { then month }=\text { int }\left(-\phi_{p}+1\right) \\
& \text { if } D<0 \text { then month }=\text { int }(-\mathrm{fp}+7) \\
& \text { if }\{C<0 \text { and } \mathrm{D}>0\} \text { then month }=\operatorname{int}\left(-\phi_{p}+13\right),
\end{aligned}
$$

where int is the integer function and $\phi_{p}$ is defined in equation 5. For example, if $\phi_{p}=-0.5$ and both $C$ and $D$ are positive, then $-\phi_{p}=0.5$, and month $=$ int $(0.5+1)=$ $\operatorname{int}(1.5)=1$, which translates to the first month of the year.

Graphs of selected constituent concentrations with Julian date (not shown), where significant seasonality was determined by equations 1 and 2 , indicated that equation 4 and equations 6-8 correctly portrayed the magnitude and timing of peak concentrations. Most data for which trend analyses were conducted were collected approximately monthly; therefore, determining annual peaks to monthly resolution is warranted. When seasonality is significant, the peak month determination should be accurate to within $+/$ 1 month. However, major ion data from sites 6,8 , and 9 , and some major ion data from site 10 were collected approximately quarterly; thus the peak "month" determined by equations 6-8 is overly precise for these data.

Regression coefficients for time trends are given in Appendix 3. The time units are years, starting on January 1,1960 . For untransformed data, a time coefficient $(E)$ of 1.0 indicates that the constituent increased at a rate of 1.0 measuring unit per year. For time trends determined from regressions of log-transformed data, the time coefficient can be converted to an annual percentage change by exponentiation of the time coefficient ( $E$, equations 1 and 2 ) and multiplying by $100:\left(10^{E}-1\right) 100$. Alternatively, a rate of change in the units of a constituent is given by the median or mean concentration times $\left(10^{E}-1\right)$ (Helsel and Hirsch, 1992). The environmental significance of statistically significant results also should be considered. For example, a statistically significant positive trend in phosphorus concentration of 0.001 milligram per liter per year may have little or no environmental significance, but a trend of 0.01 milligram per liter per year may have a substantial, and potentially harmful, environmental significance. Similarly, consistent patterns among sites or within groups of related constituents probably merit more consideration than sporadic significant relations for a constituent or site.

The last three columns of the Appendix 3 table indicate the correctness or fit of the model coefficients (B,C,D,E). The "SPEC" option of the REG (regression) procedure of SAS (SAS Institute, 1988) checks that the first and second moments of the model are correctly specified. A high p-value ( $>0.05)$ for the "SPEC" test indicates that the moments are correctly specified. Normality of residuals (Shapiro-Wilks test, UNIVARIATE procedure with NORMAL option in SAS, shown as "resnor" in the next to last column of Appendix 3), also was used to indicate fits or correctness of the model regressions. Greater $\mathrm{p}$-values $(>0.05)$ for that test indicate that the residuals are normally distributed (good fit), whereas lesser pvalues for that test indicate that the residuals were not normally distributed.

Categorical classification of the model regressions for each constituent were made as follows. The model fits were judged as "good" (Appendix 3 ) if a pvalue for "RESNOR" was greater than 0.05 and the $p$ value for "SPEC" was greater than 0.05 . If the $p$-value for "RESNOR" was greater than 0.05 , but the p-value for "SPEC" was less than 0.05 , then the model fits were judged to be "fair." If the p-value for "RESNOR" was less than 0.05 , then the model fit was judged to be "poor." Regressions judged to be "poor" are probably unsuitable for determining the relation of constituent concentrations to streamflow, season, and time. The "Constituent Trends" section of this report describes constituents with "good" and "fair" models and significant trends with discharge and/or time.

Serial auto-correlation was typically lowalways less than 0.5 . Low auto correlation is desirable for valid time-series regression models, but is not critical in this report because the regressions are not used for predictive purposes. 


\section{STATISTICAL SUMMARIES}

Statistical summaries (Appendices 1 and 2) provide basic information for each water-quality sampling site. The summaries were obtained from the UNIVARIATE procedure using SAS software version 8.00 (SAS Institute, 1988). Mean values were calculated using substitutions, either zero or the censoring level.

The number of samples collected and constituents analyzed varied by site. Data collection at site 7 , for example, was limited to measurement of specific conductance, $\mathrm{pH}$, and dissolved oxygen, whereas sites 6,9 , and 10 were sampled for analysis of nutrients, major ions, trace elements, volatile organic compounds, and pesticides. Water properties and nutrients were sampled at those sites monthly, whereas samples to be analyzed for pesticides and volatile organic compounds were collected quarterly. Data are compared to several relevant water-quality standards (table 2) in this report.

Data for selected constituents are summarized in box plots and graphs of constituent values with time. For each data set graphed in box plots, an analysis of variance (ANOVA) of data ranks for each site was conducted using the general linear model (GLM) procedure (SAS Institute, 1989a, 1989b). The data sets for each site were assigned to groups using the TukeyKramer method (SAS Institute, 1989b). Use of data ranks, rather than raw data, in parametric tests (for example, ANOVA, Tukey-Kramer) is preferred because the tests lose little power when the data are normal, and are quite robust to violations of the assumption of normality (Conover and Iman, 1981). The lettered groupings displayed on box plots are from this analysis. Sites that have the same letter designation have no significant difference in the concentrations of a constituent at $\alpha=0.05$ (confidence level of $0.95)$.

\section{Land Use}

Land use upstream of the sampling sites varies from predominantly agricultural to mixed agricultural and urban (fig. 2). Figure 2 is derived from the 15meter resolution 1995 land use coverage of U.S. Geological Survey (1999). Sites 8 and 9 bracket the reach of the North Canadian River that flows through the greater Oklahoma City urban area. Land use cover- ages of the Oklahoma City metropolitan area and adjoining counties from the mid-1970s to early 1980 s (U.S. Environmental Protection Agency, 1994) and the late 1980s to mid-1990s (U.S. Geological Survey, 1999) indicate only minor land-use changes in the study area during the 1980 s to early 1990 s.

Population in Oklahoma County grew from 568,933 in 1980 to 599,611 in 2000 , a growth rate of 16 percent during 20 years, or less than one percent per year (U.S. Census Bureau, 2001). Because of the relatively modest rates of population growth and landuse changes during the period, statistical comparisons between time-series water-quality data and those factors were not attempted for this report.

\section{Stream Discharges}

Streams in the area generally have greatest flows during the spring and early summer (April-June) (fig. 3 ). The period of lowest streamflows, which are generally several orders of magnitude less than peak flows (fig 4a), are typically in summer to fall (JulyNovember) and in early winter (December-January).

Water-quality data were not collected over the full range of streamflow conditions, but generally were representative of the majority of streamflows recorded at the sites (fig. 4a). Streamflows of all of the sampled streams are regulated by control structures, and by the relatively constant drainages from alluvial and bedrock aquifers, municipal wastewater treatment plants, and other urban runoff.

Stream discharges measured during sampling at the sites on Bluff, Deer, and Chisholm Creeks typically ranged from 0.3 cubic foot per second to 70 cubic feet per second (fig. 4b). For the sites on the North Canadian River, stream discharges generally ranged from 10 cubic feet per second to 1,500 cubic feet per second (fig. 4b). Samples collected quarterly and monthly from the North Canadian River sites 6 and 10 had similar ranges of streamflows as recorded by mean monthly and mean daily values at the gages (fig. 4). Streamflows during sampling were somewhat less than the mean monthly and daily values recorded at the gages at sites 8 and 9 (fig. 4b). Greater instantaneous streamflows than the mean daily streamflows have occurred at these sites during that period and those maximum flows are not represented by the samples (fig. 4b). Table 3 summarizes historic flow in 
Table 2. Explanation of water-quality standards referenced in this report.

\begin{tabular}{|c|c|c|}
\hline Standard & Explanation & Citation \\
\hline \multicolumn{3}{|c|}{ Drinking-Water Standards } \\
\hline $\begin{array}{l}\text { Maximum Contaminant } \\
\text { Level }\end{array}$ & $\begin{array}{l}\text { Drinking-water standard set by the U.S. Environmental Protec- } \\
\text { tion Agency to minimize health threats. }\end{array}$ & $\begin{array}{l}\text { U.S. Environmental Protec- } \\
\text { tion Agency (1995) }\end{array}$ \\
\hline $\begin{array}{l}\text { Secondary Maximum } \\
\text { Contaminant Level }\end{array}$ & $\begin{array}{l}\text { Drinking-water standard set by the U.S. Environmental Protec- } \\
\text { tion Agency to minimize water-quality nuisances. }\end{array}$ & $\begin{array}{l}\text { U.S. Environmental Protec- } \\
\text { tion Agency (1995) }\end{array}$ \\
\hline $\begin{array}{l}\text { Raw Water Numerical Crite- } \\
\text { rion }\end{array}$ & $\begin{array}{l}\text { Concentration limits set by the State of Oklahoma for surface } \\
\text { water to be used for drinking water. }\end{array}$ & $\begin{array}{l}\text { Oklahoma Water Resources } \\
\text { Board (2000) }\end{array}$ \\
\hline \multicolumn{3}{|c|}{ Ambient Water-Quality Criteria } \\
\hline $\begin{array}{l}\text { Criterion Maximum Concen- } \\
\text { tration }\end{array}$ & $\begin{array}{l}\text { An estimate of the highest concentration of a material in } \\
\text { surface water to which an aquatic community can be exposed } \\
\text { briefly without resulting in an unacceptable effect: }\end{array}$ & $\begin{array}{l}\text { U.S. Environmental Protec- } \\
\text { tion Agency }(1976,1999)\end{array}$ \\
\hline $\begin{array}{l}\text { Criterion Continuous } \\
\text { Concentration }\end{array}$ & $\begin{array}{l}\text { An estimate of the highest concentration of a material in } \\
\text { surface water to which an aquatic community can be exposed } \\
\text { indefinitely without resulting in an unacceptable effect. }\end{array}$ & $\begin{array}{l}\text { U.S. Environmental Protec- } \\
\text { tion Agency }(1976,1999)\end{array}$ \\
\hline $\begin{array}{l}\text { Human Health Criterion for } \\
\text { Consumption of Water and } \\
\text { Organism }\end{array}$ & $\begin{array}{l}\text { This criterion is for protection of human health with respect to } \\
\text { bioaccumulative contaminants that may be consumed by } \\
\text { drinking the source water, and by eating fish tissue. }\end{array}$ & $\begin{array}{l}\text { U.S. Environmental Protec- } \\
\text { tion Agency (1976) }\end{array}$ \\
\hline $\begin{array}{l}\text { Water Column Criterion to } \\
\text { Protect for Consumption of } \\
\text { Fish Flesh and Water }\end{array}$ & $\begin{array}{l}\text { Concentration limits set by the State of Oklahoma for surface } \\
\text { water to be used for drinking water and fishing/harvesting }\end{array}$ & $\begin{array}{l}\text { Oklahoma Water Resources } \\
\text { Board (2000) }\end{array}$ \\
\hline $\begin{array}{l}\text { Criterion Used for Protection } \\
\text { of Fish and Wildlife Propa- } \\
\text { gation }\end{array}$ & $\begin{array}{l}\text { Concentration limits set by the State of Oklahoma for surface } \\
\text { water to be inhabited by wildlife. }\end{array}$ & $\begin{array}{l}\text { Oklahoma Water Resources } \\
\text { Board (2000) }\end{array}$ \\
\hline $\begin{array}{l}\text { Numerical Criterion for Toxic } \\
\text { Substances }\end{array}$ & $\begin{array}{l}\text { Concentration limits set by the State of Oklahoma for surface } \\
\text { water to prevent acute or chronic toxicity for aquatic biota. }\end{array}$ & $\begin{array}{l}\text { Oklahoma Water Resources } \\
\text { Board (2000) }\end{array}$ \\
\hline $\begin{array}{l}\text { Primary Body Contact for } \\
\text { Recreation }\end{array}$ & $\begin{array}{l}\text { Concentration limits set by the State of Oklahoma for surface } \\
\text { water to prevent illness in recreational users. }\end{array}$ & $\begin{array}{l}\text { Oklahoma Water Resources } \\
\text { Board (2000) }\end{array}$ \\
\hline $\begin{array}{l}\text { Water Column criterion to } \\
\text { Protect for Consumption of } \\
\text { Fish Flesh }\end{array}$ & $\begin{array}{l}\text { Concentration limits set by the State of Oklahoma for surface } \\
\text { water to prevent harm to people consuming fish. }\end{array}$ & $\begin{array}{l}\text { Oklahoma Water Resources } \\
\text { Board (2000) }\end{array}$ \\
\hline
\end{tabular}



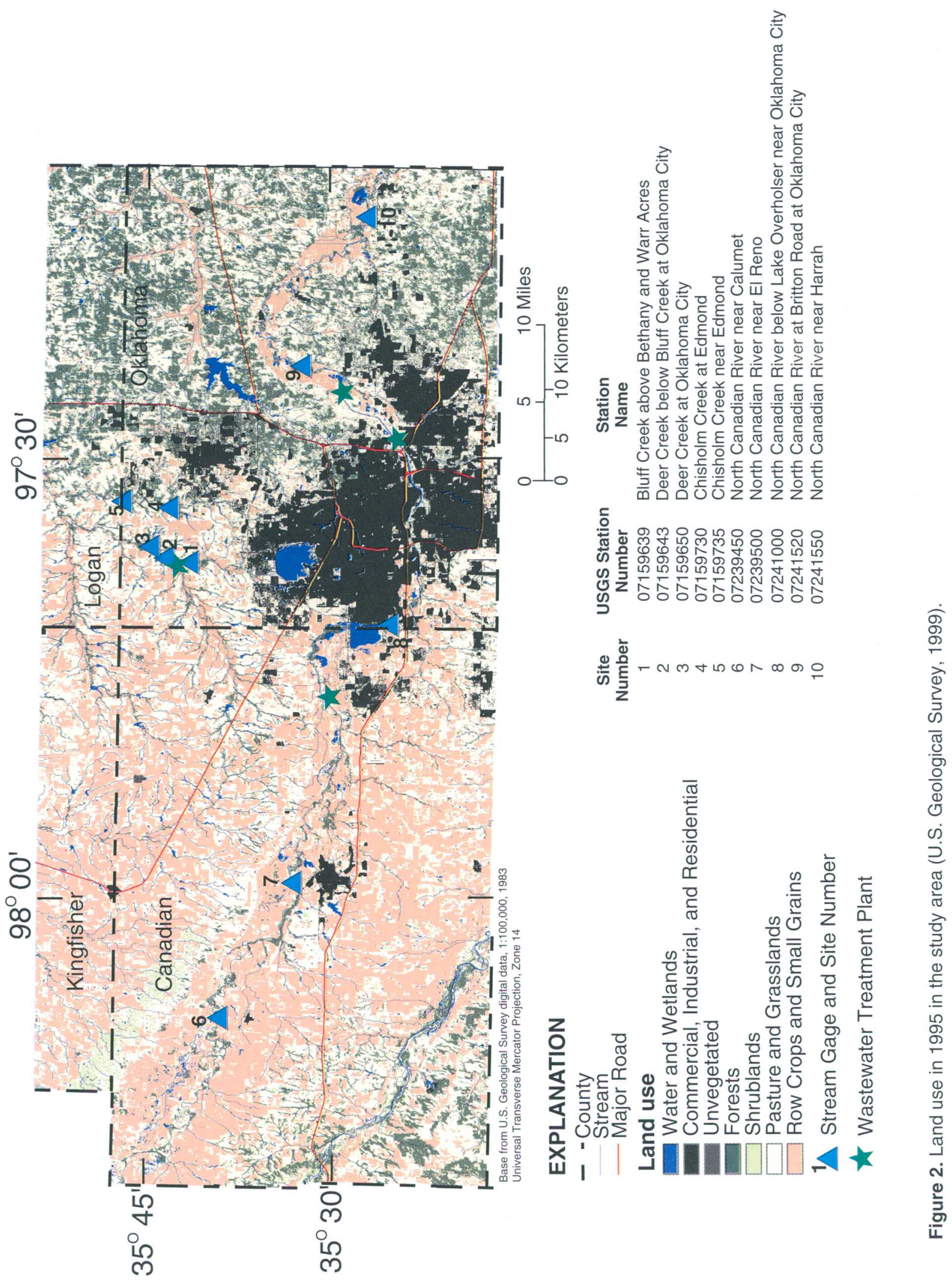

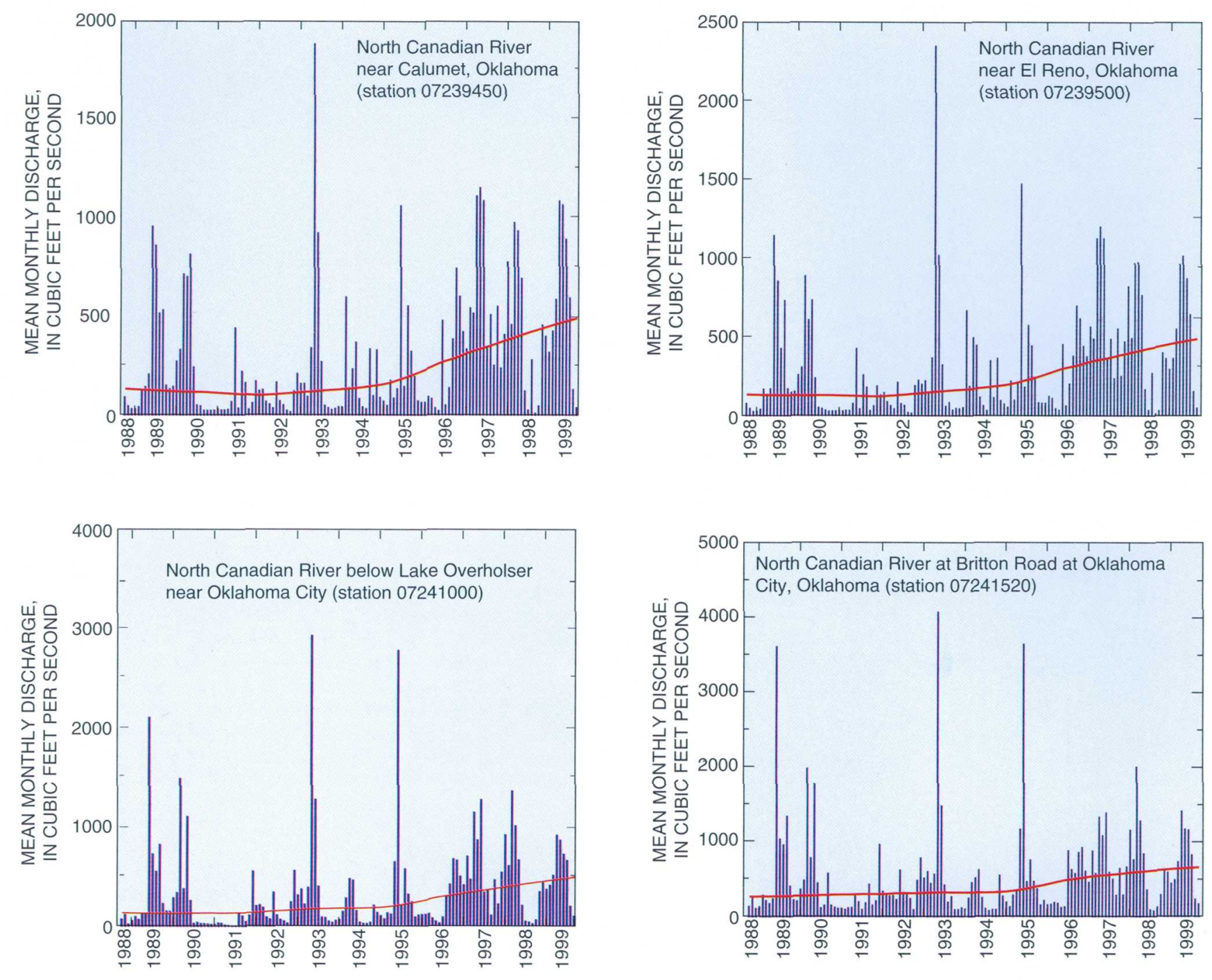

\section{EXPLANATION}
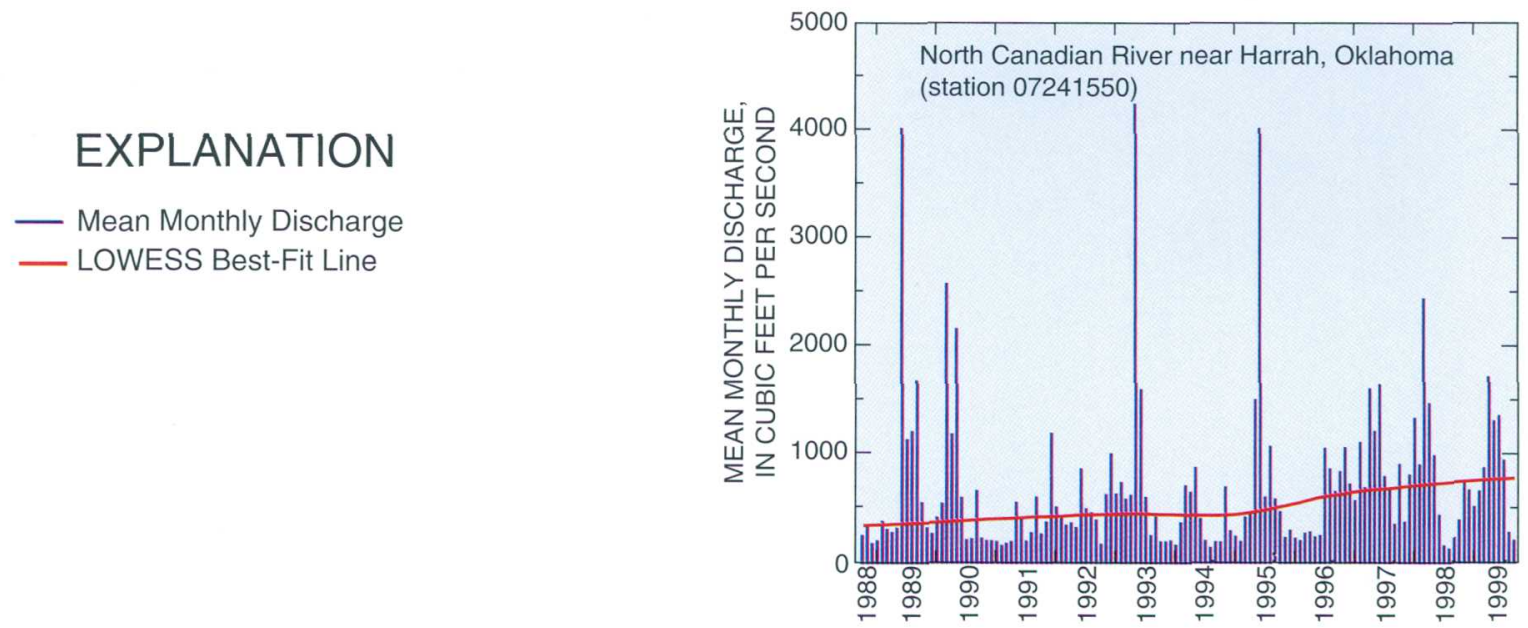

Figure 3. Mean monthly streamflows at stations on the North Canadian River near Oklahoma City, October 1988September 1999. 

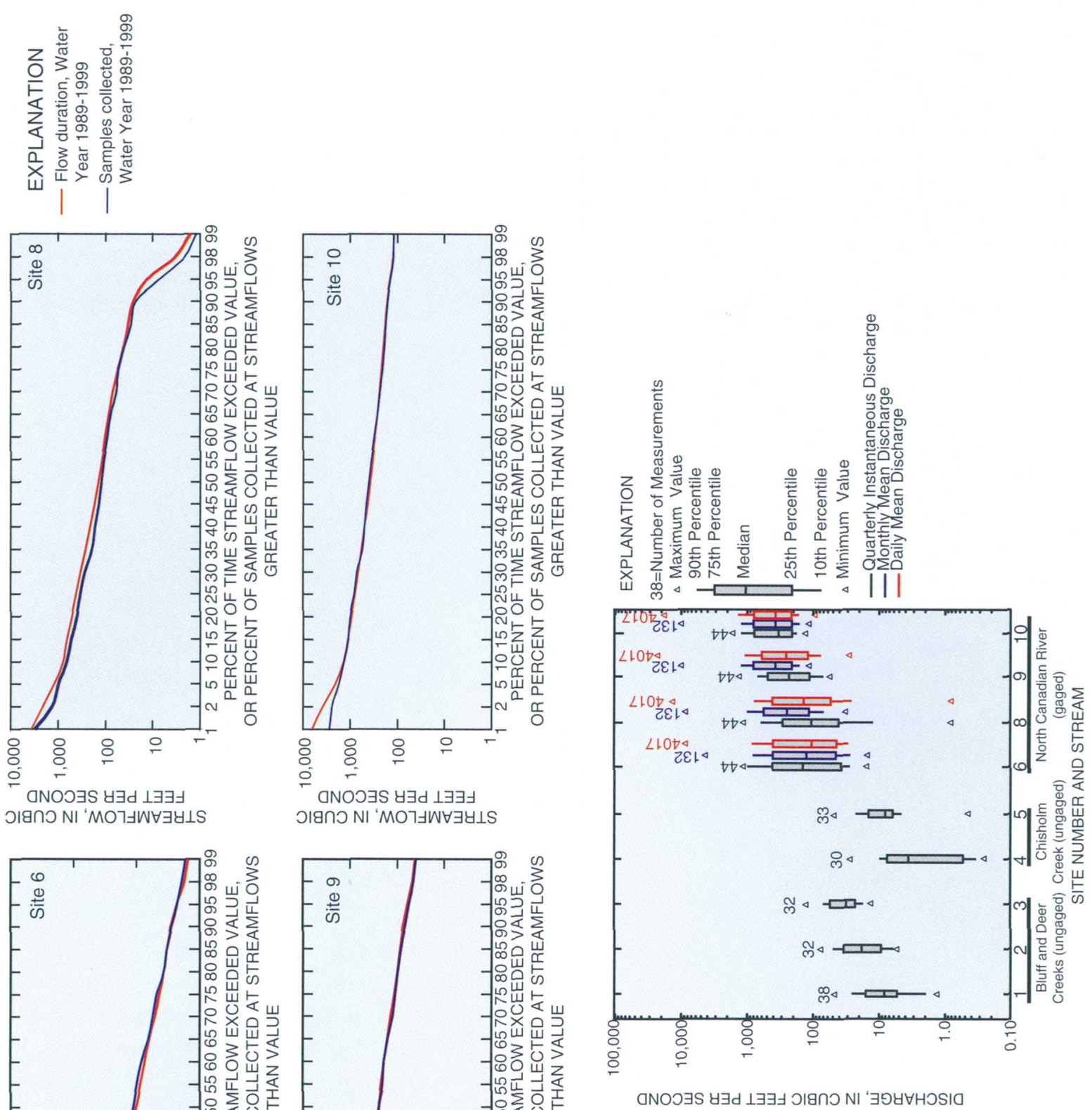

․ㅗำ

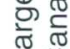

든

은

월

뜽

需

으묻

달

市

匹

뜬

원

ठำ

당

을

$\stackrel{\oplus}{ \pm}$

등 묻

\& 당

क

용

$\frac{\Phi}{0}=$

क)

๘

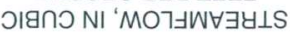

วเยกว NI 'MOา
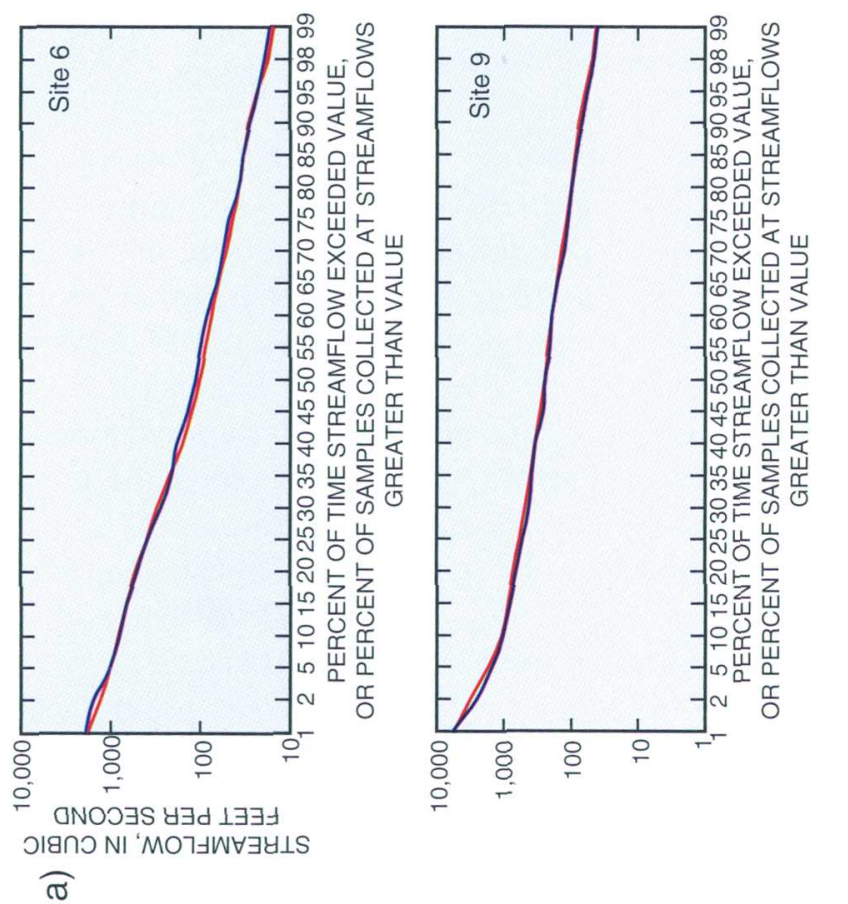

อ 
Table 3. Drainage areas and flow characteristics for the sites on the North Canadian River (Blazs and others, 2000)

[all units in cubic feet per second, unless otherwise specified]

\begin{tabular}{|c|c|c|c|c|c|}
\hline \multirow[b]{2}{*}{ Flow Statistic (1989-2000) } & \multicolumn{5}{|c|}{ Site } \\
\hline & $\begin{array}{c}\text { North Cana- } \\
\text { dian River } \\
\text { near } \\
\text { Calumet } \\
\text { (site 6, Water } \\
\text { Years 1989- } \\
\text { 2000) }\end{array}$ & $\begin{array}{c}\text { North Cana- } \\
\text { dian River } \\
\text { near El Reno } \\
\text { (site 7, Water } \\
\text { Years 1949- } \\
\text { 2000) }\end{array}$ & $\begin{array}{c}\text { North Cana- } \\
\text { dian River } \\
\text { below Lake } \\
\text { Overholser } \\
\text { (site 8, Water } \\
\text { Years 1953- } \\
\text { 2000) }\end{array}$ & $\begin{array}{c}\text { North Cana- } \\
\text { dian River at } \\
\text { Britton Road } \\
\text { (site 9, Water } \\
\text { Years 1989- } \\
\text { 2000) }\end{array}$ & $\begin{array}{c}\text { North Cana- } \\
\text { dian River } \\
\text { near Harrah } \\
\text { (site 10), } \\
\text { Water Years } \\
\text { 1969-2000) }\end{array}$ \\
\hline Drainage Area (square miles) & 12,962 & 13,042 & 13,222 & 13,413 & 13,501 \\
\hline Annual Mean Flow & 301 & 234 & 186 & 542 & 500 \\
\hline Highest Annual Mean Flow & 635 & 807 & 749 & 835 & 1,322 \\
\hline Lowest Annual Mean Flow & 85.3 & 31.8 & 0.42 & 167 & 93.0 \\
\hline Highest Daily Mean Flow & 8,430 & 13,300 & 13,300 & 22,700 & 20,000 \\
\hline Lowest Daily Mean Flow & 9.1 & 0.0 & 0.0 & 28 & 28 \\
\hline Annual Seven-Day Minimum Flow & 10 & 0.0 & 0.0 & 32 & 31 \\
\hline Instantaneous Peak Flow & 9,310 & 15,000 & 19,500 & 38,100 & 27,200 \\
\hline Instantaneous Peak Stage & 14.32 & 22.22 & 29.85 & 24.80 & 22.64 \\
\hline Annual Runoff (acre-feet) & 218,100 & 169,600 & 134,500 & 392,300 & 362,000 \\
\hline 10 Percent of Flows Exceed & 852 & 700 & 520 & 1,100 & 1,080 \\
\hline 50 Percent of Flows Exceed & 105 & 58 & 22 & 252 & 225 \\
\hline 90 Percent of Flows Exceed & 29 & 2.4 & 0.77 & 74 & 72 \\
\hline
\end{tabular}

the North Canadian River at five sites near Oklahoma City.

Surface water from the North Canadian River is the primary source of water to Oklahoma City and several neighboring municipalities, with approximately 57 million gallons per day of surface water used in Oklahoma County, and 21 million gallons per day of ground water withdrawn in the county in 1995 (Tortorelli, 2000).

\section{Water Properties}

Specific conductance, an indicator of dissolved ionic substances, generally increased downstream at the sites on Bluff, Deer, and Chisholm Creeks (fig. 5). Samples from Bluff, Deer, and Chisholm Creeks have lesser specific conductance than those from the sites on the North Canadian River, perhaps due to smaller drainage areas and lesser residence times for groundwater baseflow in those smaller basins.

Specific conductance values, which were greater in the North Canadian River, tended to decrease in the downstream direction on that river. Specific conductance at sites 8, 9, and 10 may be affected by sorption and precipitation of substances in Lake Overholser, ground-water discharge from alluvial and bedrock aquifers, increased annual rainfall in the eastern part of the area, fewer evaporitic mineral deposits in the eastern end of the study area, and urban runoff. Specific conductance values recorded by continuous monitors operated at sites 6 and 8 during this period were quite similar to the instantaneous values measured in the field (fig. 5). Continuous specific conductance values at sites 9 and 10 generally were a few percent less than those recorded during sampling events (fig. 5). Similar to specific conductance (fig. 5), dissolved solids concentration decreased in the down- 


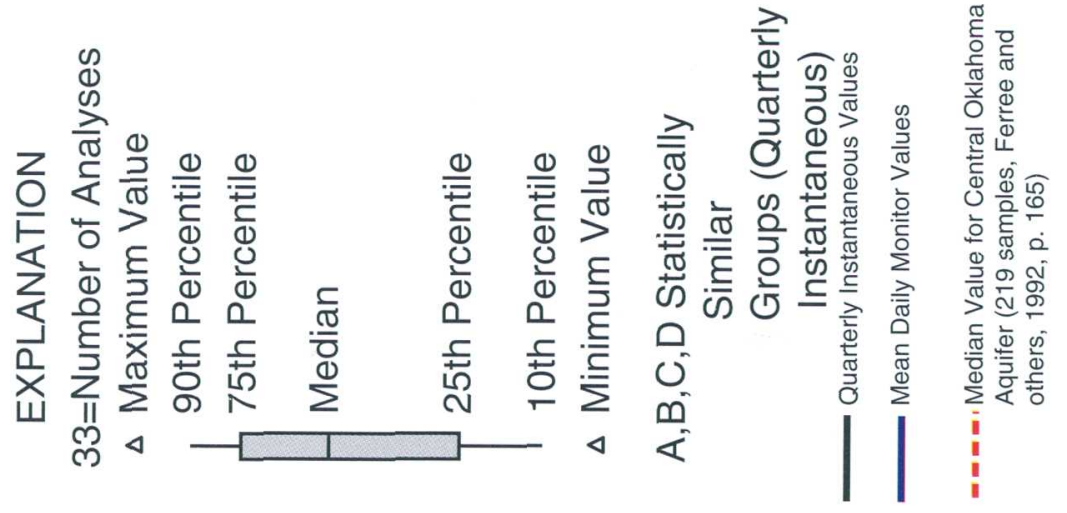



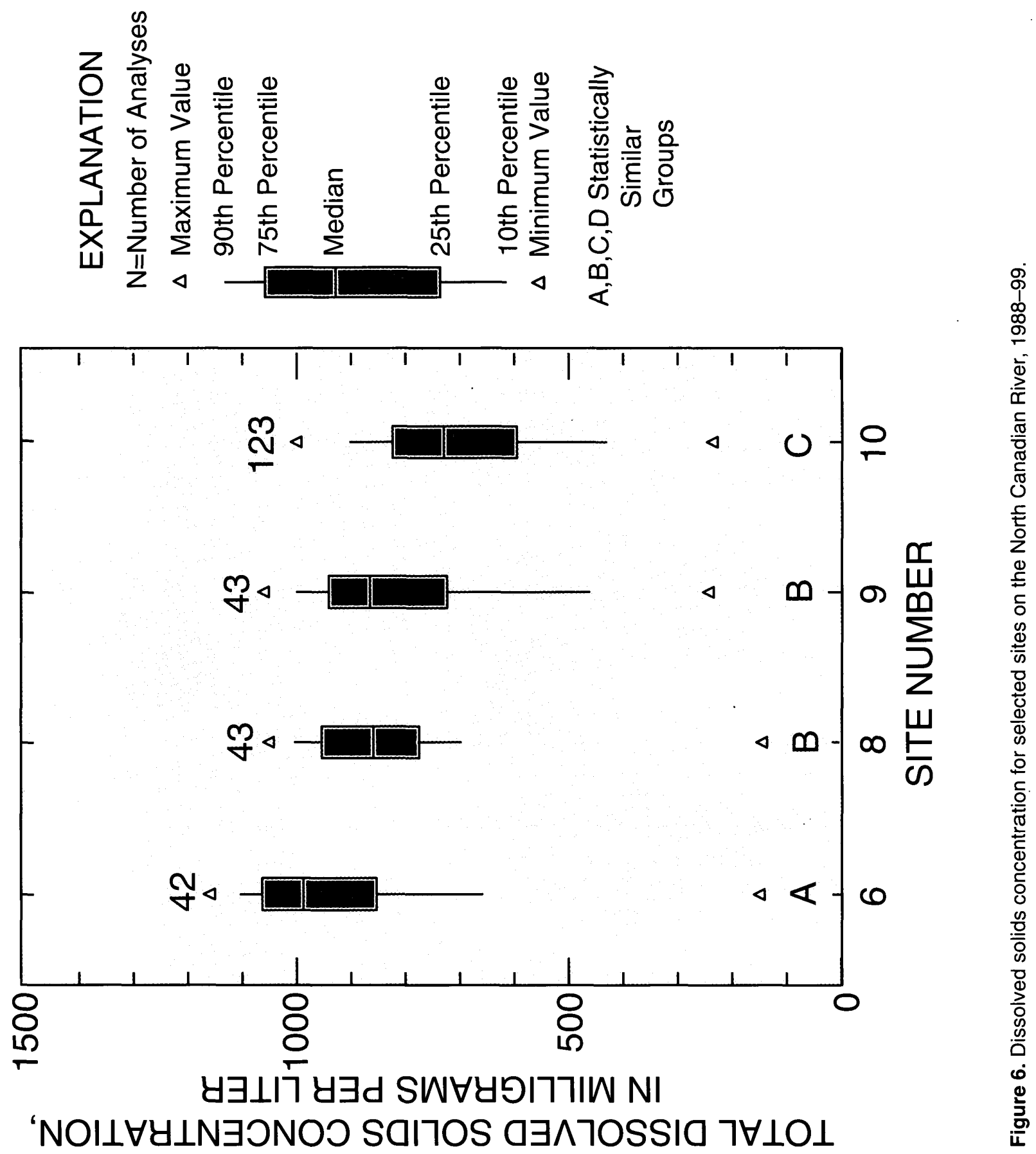
stream direction for the stations on the North Canadian River (fig. 6).

Dissolved oxygen concentrations were generally greater at the four sites on the North Canadian River, but between 5 and 10 percent of samples measured at those sites had dissolved oxygen concentrations that were less than the Oklahoma Criteria to Protect Fish and Wildlife Propagation (figs. 7 and 8). Instantaneous dissolved oxygen measurements were made in daylight, when algal photosynthesis adds oxygen to water; continuous monitors record dissolved oxygen concentration hourly. Abundant algal populations also can bring about decreased dissolved oxygen concentrations because of algal respiration during non-daylight hours and oxygen demand from decomposition of algae.

Dissolved oxygen concentrations from continuous monitors installed at sites $6,8,9$, and 10 during this period generally were a few percent less than those collected during field sampling trips (fig. 7) Continuously monitored dissolved oxygen concentrations at site 10 decrease to about 1.0 milligram per liter at night, particularly during summer (fig. 8); these low concentrations can be hazardous to many aquatic species. Due in part to algal photosynthesis, dissolved oxygen concentrations exceeded 100 percent of saturation in more than 50 percent of the measurements at some sites on the North Canadian River (fig. 9).

Whereas dissolved oxygen concentrations were similar between the North Canadian River sites, carbon dioxide concentrations, which tend to indicate biological consumption of organic carbon and respiration, generally increased as the river flowed toward site 10 (fig. 10). Biochemical oxygen demand, another indicator of the aerobic consumption of organic matter, also tended to increase in the downstream direction (fig. 11). Dissolved oxygen concentrations were similar at the five sites on Bluff, Deer, and Chisholm Creeks, but were periodically less than the minimum Oklahoma Criterion to Protect Fish and Wildlife Propagation (fig. 7). Dissolved oxygen in Bluff, Deer, and Chisholm Creeks reached supersaturation less frequently than in the North Canadian River, indicating that those streams may not have algal populations as great as those in the North Canadian River or that there is lesser oxygen demand from organic substances in those streams.

Turbidity, which may be contributed by algae and suspended sediments, increased slightly in the downstream direction for the North Canadian River sites (fig. 12).Greater median turbidity at site 10 reflects greater stream velocities at that site and erodible river banks between sites 6 and 10. As at many stream sites, turbidities generally increased markedly with increased streamflow at site 10 (fig. 13).

\section{Sulfate and Chloride}

Seventy-five percent of water samples collected at site 6 and 50 percent of samples collected at site 8 exceeded the Secondary Maximum Contaminant Level of 250 milligrams per liter for sulfate (fig. 14). Sulfate concentrations decreased in the downstream direction in the North Canadian River. Bedrock underlying upstream reaches of the Noth Canadian River contains gypsum beds known to be sources of sulfate in ground water and surface water (Ham, 1962). Possible reasons for that decrease may include: (1) dilution by ground-water discharging from the Central Oklahoma aquifer, (2) greater rainfall toward the east and lesser amounts of gypsum in geologic units underlying the eastern part of the study area, (3) dilution of water flowing from the west by local tributary inflows, and (4) reduction of sulfate to hydrogen sulfide in anoxic waters near the bottom of Lake Overholser.

The Criterion Continuous Concentration limit for aquatic species of 230 milligrams per liter for chloride was exceeded in about 20 percent of the samples from sites 6 and 9 and in about 10 percent of samples from site 10 (fig. 15). Chloride concentrations exceeded the Secondary Maximum Contaminant Level in about 15 percent of the samples from sites 6 and 9 (fig. 15). Chloride concentrations in the North Canadian River decreased from site 6 to site 8 , but increased from site 8 to sites 9 and 10, perhaps due to discharges from upstream outfalls of treated municipal wastewater and ground-water discharge from the Central Oklahoma aquifer. The area of the Central Oklahoma aquifer between sites 8 and 9 is noted for having relatively high proportions of sodium and chloride (Ferree and others, 1992, p. 20). Halite is used for de-icing roads in the Oklahoma City area, but usually only for a few days per year.

Sulfate and chloride also may be related to oil field waste. Prior to the 1970 s, brines and petroleum wastes were commonly disposed in open, unlined pits. Thousands of these abandoned pits may be an additional source of these ions to the North Canadian River. 

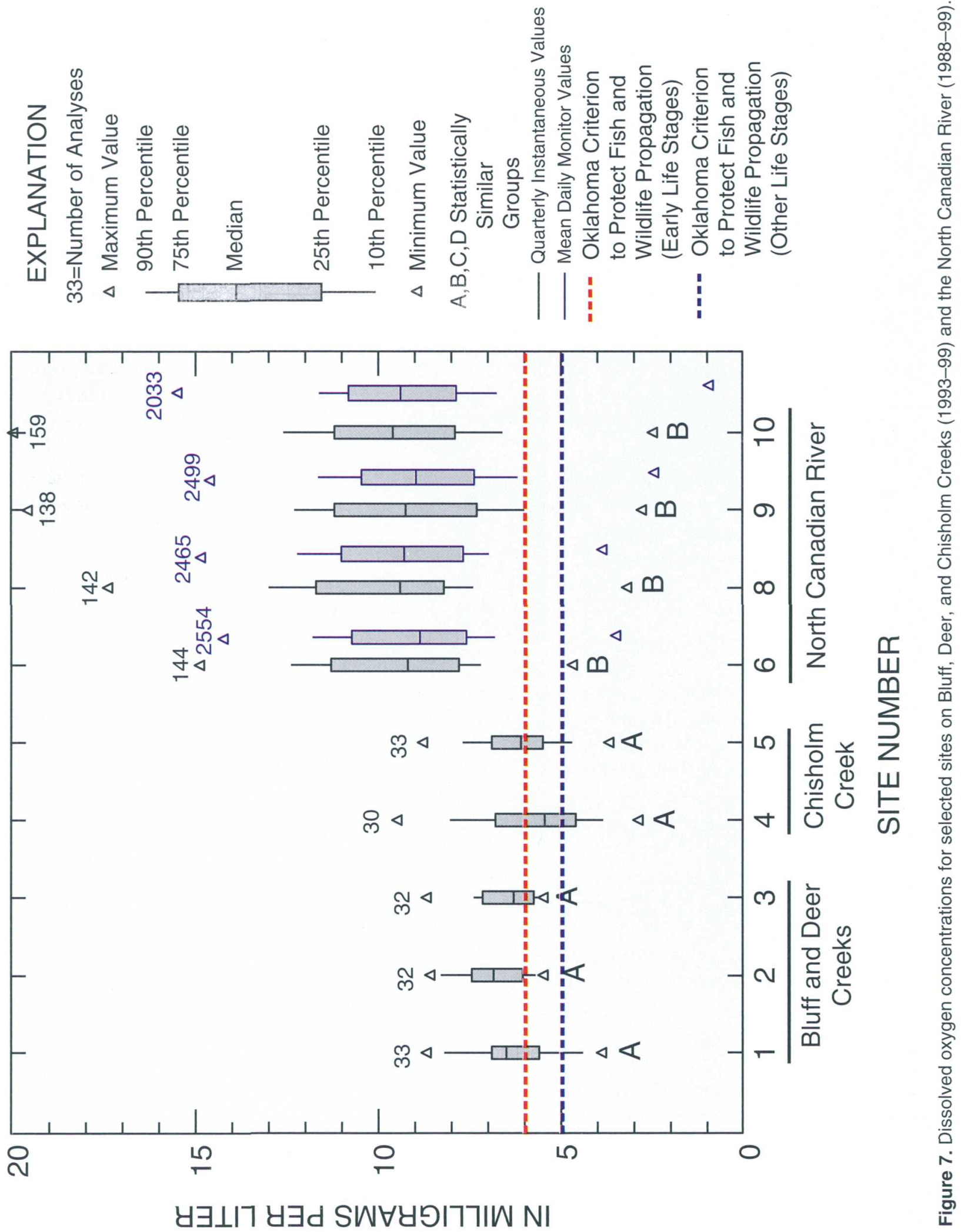

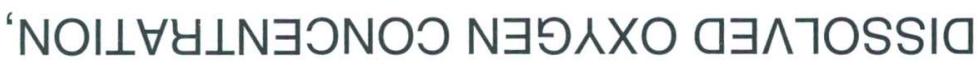




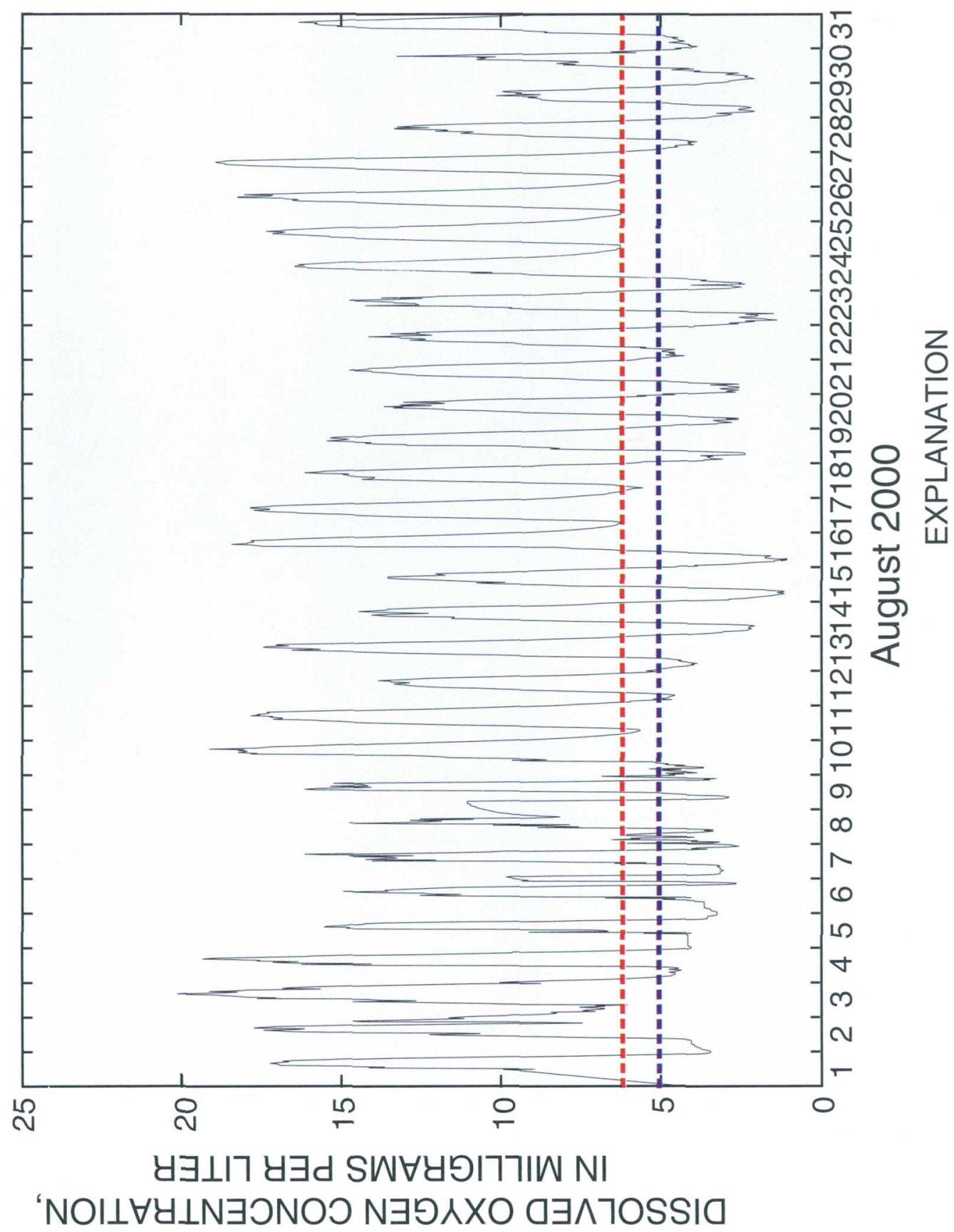



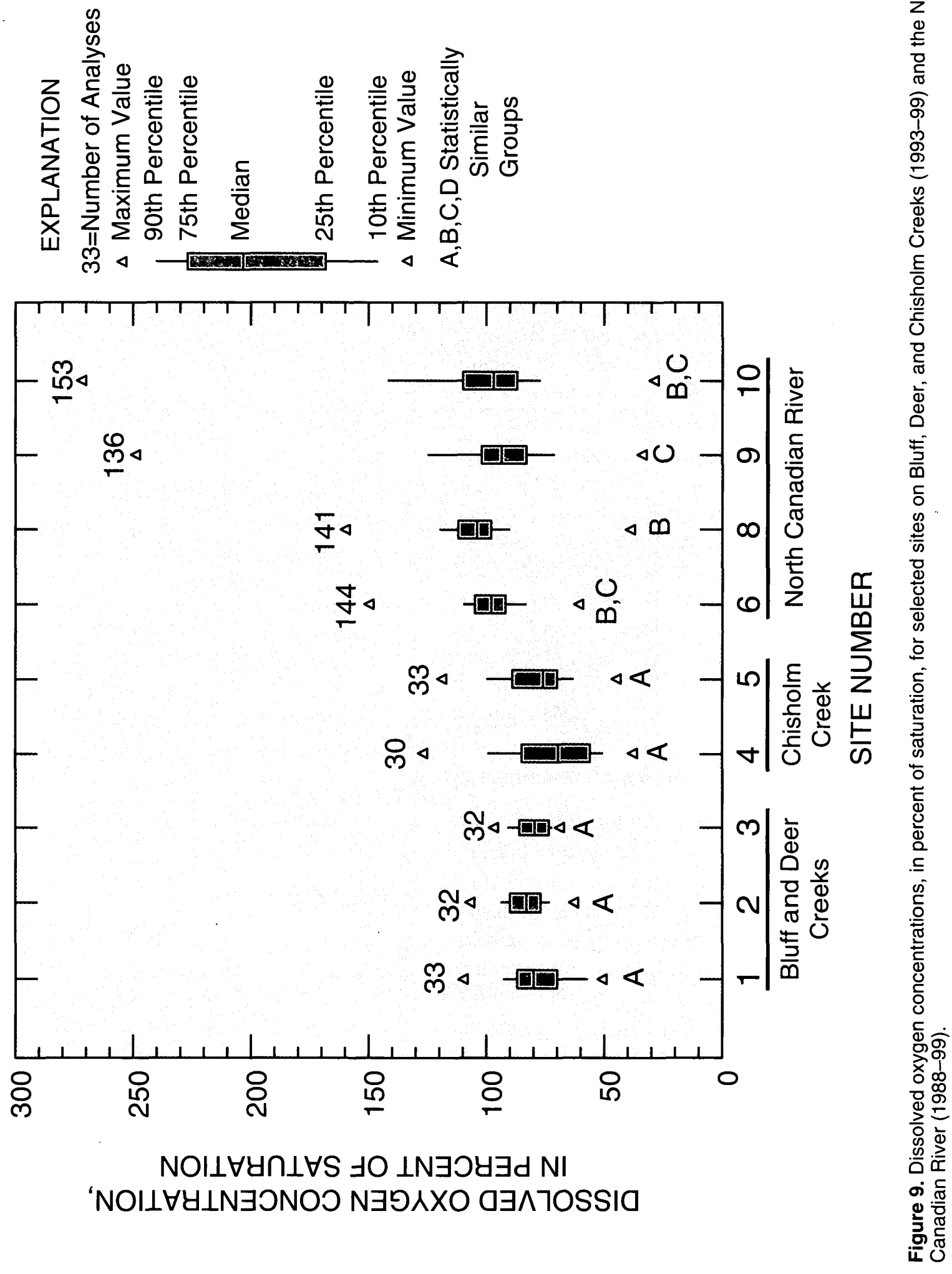


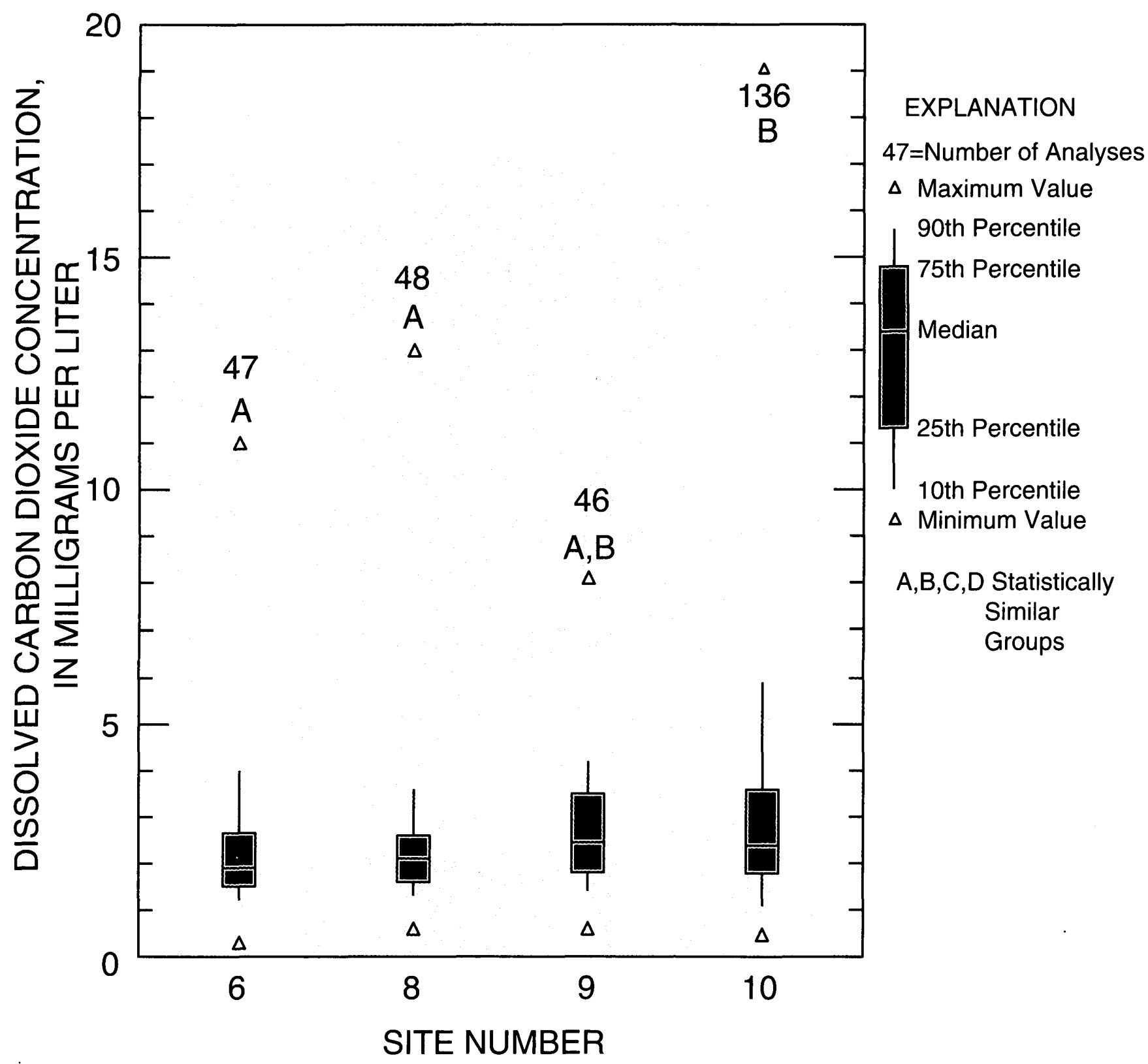

Figure 10. Carbon dioxide concentration for selected sites on the North Canadian River, 1988-99. 


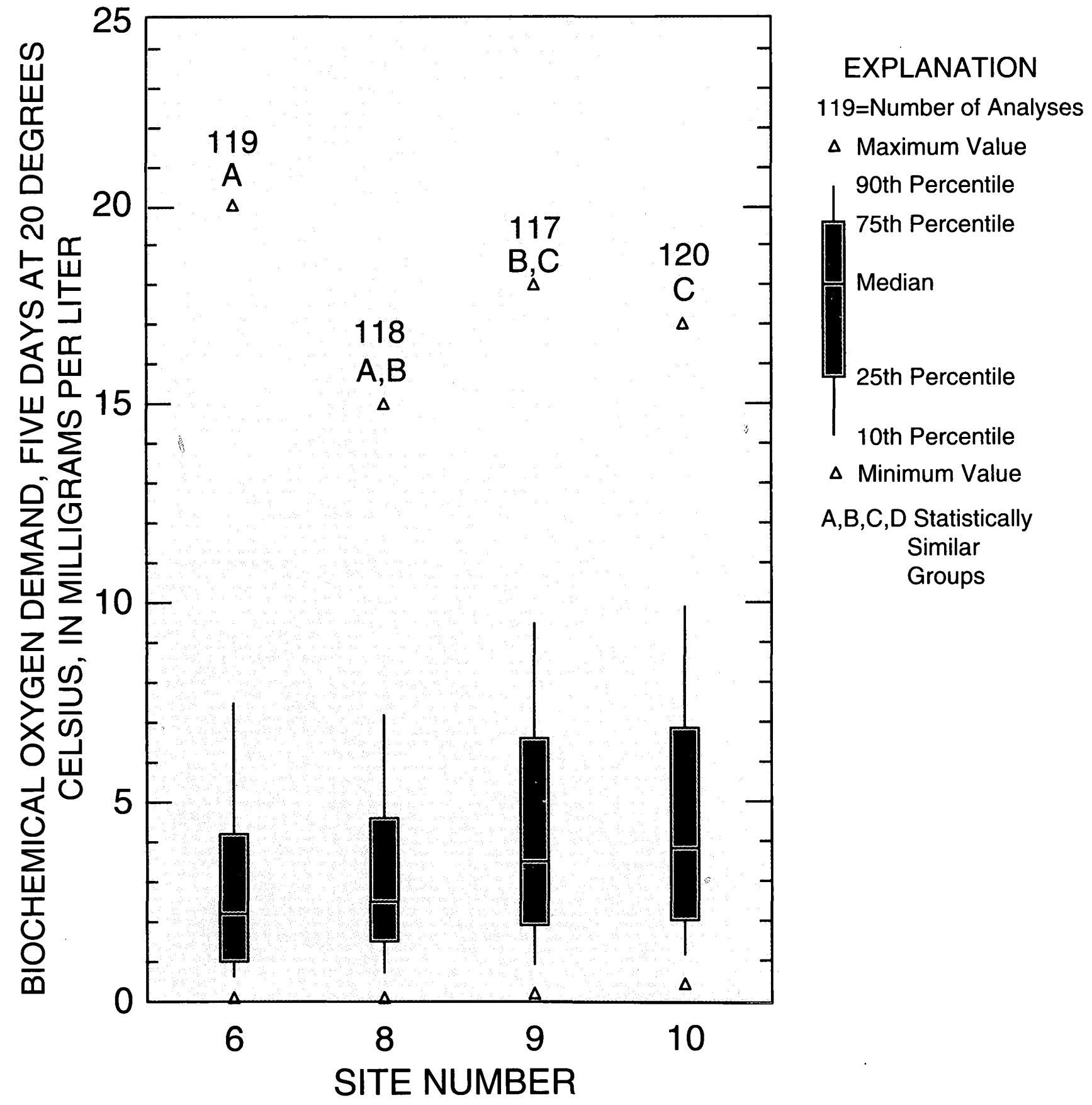

Figure 11. Five-day biochemical oxygen demand for selected sites on the North Canadian River, 1988-99. 


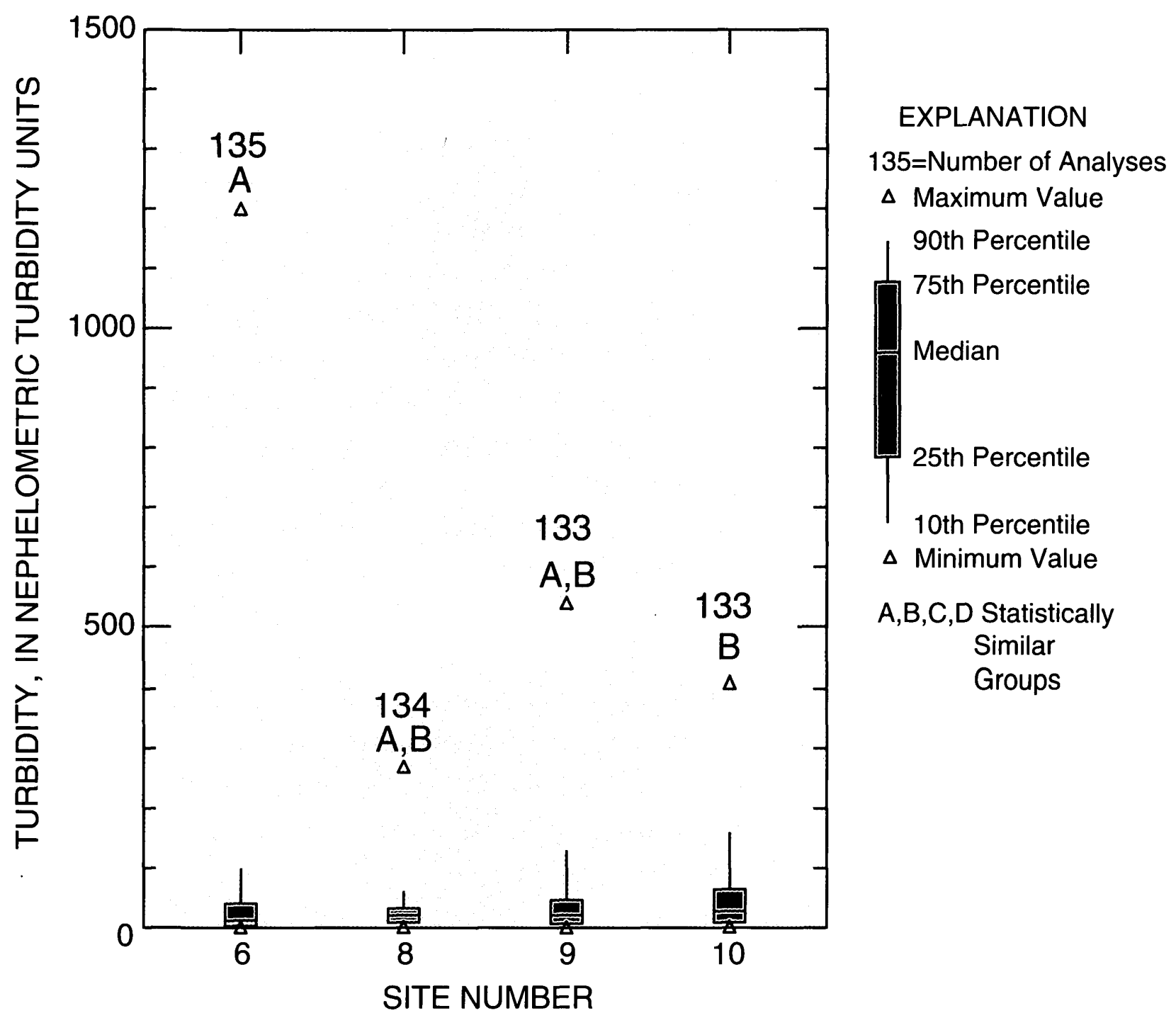

Figure 12. Turbidity for selected sites on the North Canadian River, 1988-99. 


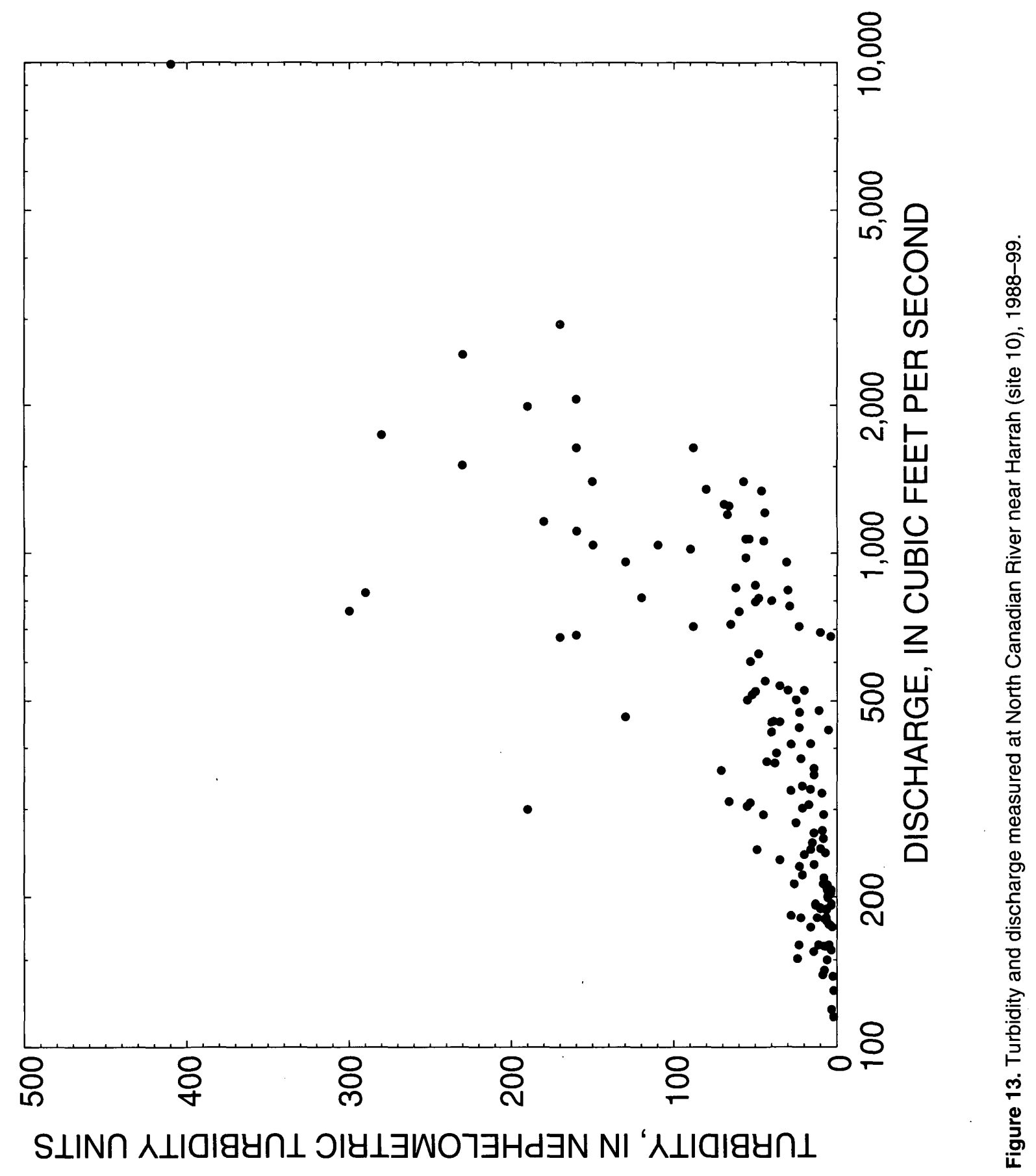




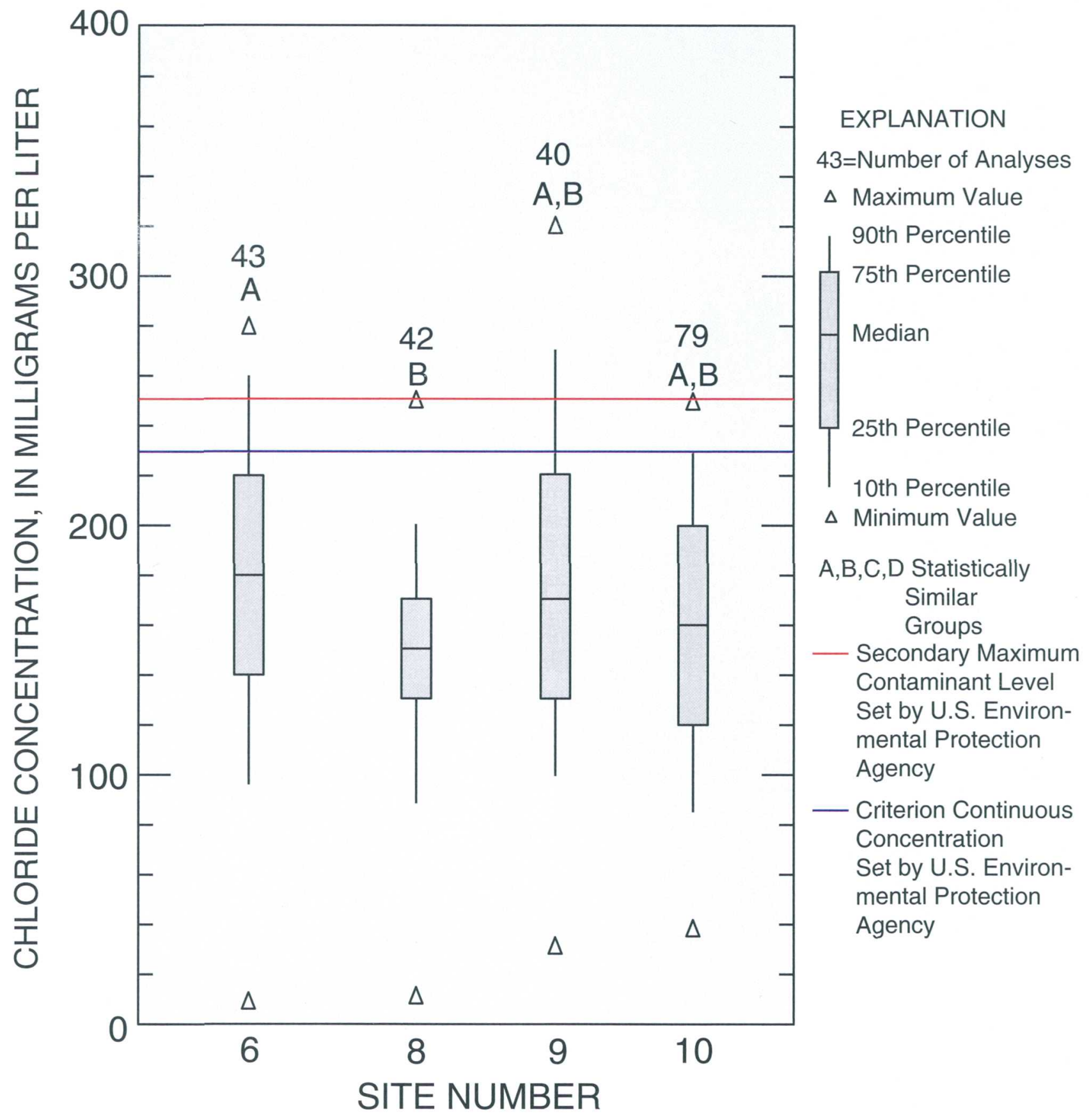

Figure 15. Chloride concentration for selected sites on the North Canadian River, 1988-99. 


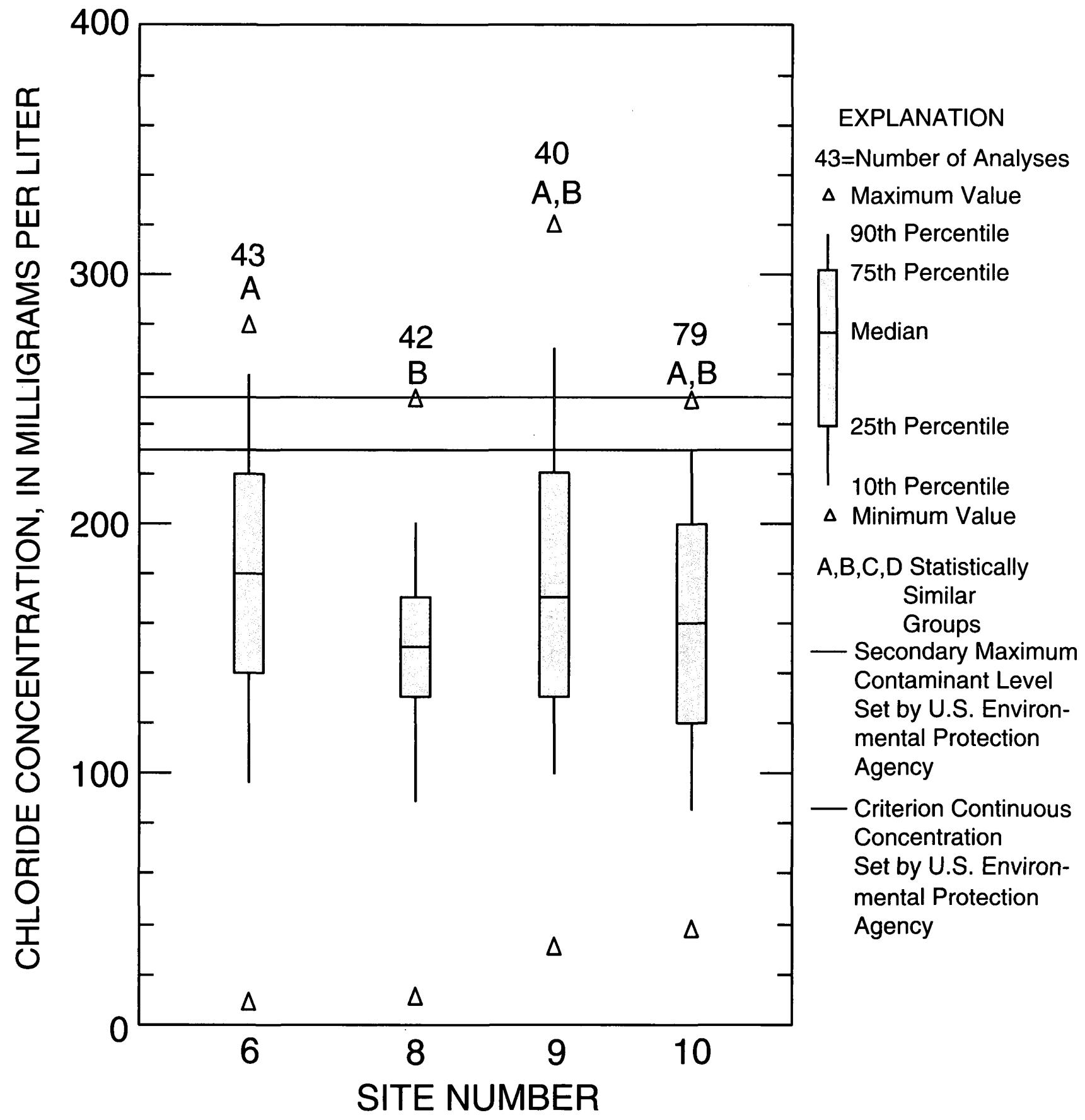

Figure 15. Chloride concentration for selected sites on the North Canadian River, 1988-99. 
Table 4. Number of samples collected and median concentrations of nutrients in the Mississippi River and its tributaries and undeveloped basins in the United States

[concentrations in milligrams per liter]

\begin{tabular}{lcc}
\hline \multicolumn{1}{c}{ Nutrient } & Number of samples & Median concentration \\
\hline \multicolumn{4}{c}{ Mississippi River (Antweiler and others, 1995) } \\
Nitrate-nitrogen & 576 & 2.1 \\
Nitrite-nitrogen & 577 & 0.02 \\
Ammonia-nitrogen & 570 & 0.01 \\
Orthophosphate-phosphorus & 582 & 0.080 \\
\multicolumn{1}{c}{ Mississippi River Tributaries (Antweiler and others, 1995) } \\
Nitrate-nitrogen & 196 & 0.75 \\
Nitrite-nitrogen & 194 & 0.02 \\
Ammonia-nitrogen & 176 & 0.02 \\
Orthophosphate-phosphorus & 190 & 0.034 \\
$\quad$ Undeveloped Basins in the United States (Fuhrer and others, 1999) \\
Nitrate-nitrogen & 85 & 0.087 \\
Nitrite-nitrogen & 85 & -- \\
Ammonia-nitrogen & 85 & 0.02 \\
Orthophosphate-phosphorus & 85 & 0.01 \\
\hline
\end{tabular}

\section{Nutrients and Organic Carbon}

Nitrogen and phosphorus compounds are essential plant nutrients that can cause eutrophication in aquatic environments when present in high concentrations. These nutrients are most commonly derived from soils, vegetation, animal wastes, and fertilizers. Antweiler and others (1995) provide a statistical summary of nutrient concentrations measured in the Mississippi River and its tributaries (table 4). Fuhrer and others (1999) provide a summary of nutrient concentrations measured at 85 stream sites in undeveloped basins across the U.S. Nutrient data from the North Canadian River are compared to those data to provide a frame of reference to that larger river system, into which the North Canadian and adjoining rivers drain.

Nitrite concentrations in the North Canadian River increase slightly from site 6 to site 10 , with most concentrations being less than 0.1 milligram per liter. Nitrite is an unstable intermediate compound, formed during nitrification or denitrification, which typically occurs in relatively low concentrations. Only 1 of 134 samples from site 10 (collected on 9/9/1988) from 1988-1999 had a nitrite concentration exceeding the Maximum Contaminant Level of 1.0 milligram per liter (U.S. Environmental Protection Agency, 1999) (fig. 16). However, samples collected from 1977-87 at site 10 had eight exceedances of the Maximum Contaminant level. These relatively high concentrations of nitrite may be related to wastewater treatment plant discharges upstream of this site. Median nitrite concentrations at sites 9 and 10 are greater than the median for Mississippi River tributaries and for undeveloped basins (table 4, Appendix 2).

Nitrite plus nitrate concentrations are less than the 10 milligrams per liter Oklahoma Raw Water Numerical Criterion and the Maximum Contaminant Level (Oklahoma Water Resources Board, 2000; U.S. Environmental Protection Agency, 1995). In this report "nitrate" is used for "nitrate plus nitrate, as nitrogen" for brevity and because nitrate is the predominant oxidized nitrogen compound dissolved. 


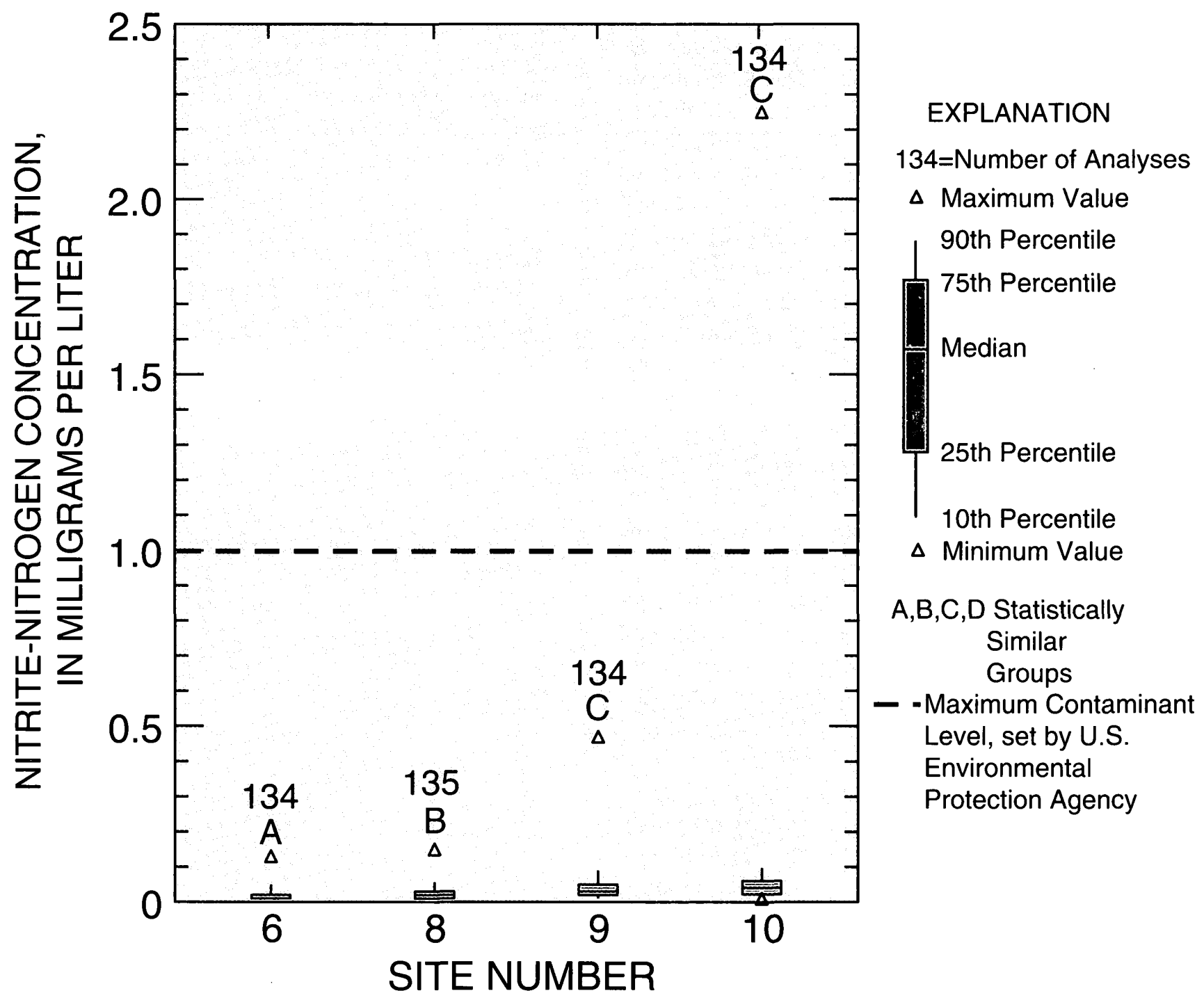

Figure 16. Nitrite-nitrogen concentration for selected sites on the North Canadian River, 1988-99. 
in water. Median nitrate concentrations at sites 9 and 10 were greater than the median value for Mississippi River tributaries and for undeveloped basins in the U.S. (Appendix 2, table 4). Nitrate concentrations typically are greater below wastewater treatment plant outfalls because of nitrification treatment of municipal wastewater. Nitrate is the most common oxidized form of nitrogen in water and the most common form of dissolved nitrogen that is bioavailable. It is formed by nitrification (oxidation) of ammonia and may be removed, in reducing conditions, by denitrification. Median nitrate concentrations ranged from 0.44 milligram per liter at site 6 to 1.9 milligrams per liter at site 10 (Appendix 2, fig. 17). Maximum nitrite plus nitrate concentrations ranged from 2.4 milligrams per liter at site 6 to 6.8 milligrams per liter at site 10 (Appendix 2, fig. 17).

Ammonia concentrations increased from site 6 to site 9 and decreased at site 10 (fig. 18) and median ammonia concentrations at all sites were greater than the median concentration for Mississippi River tributaries and undeveloped watersheds in the U.S.

(Appendix 2, table 4). Ammonia concentrations are determined by analyzing water samples for total ammonia. Criterion Continuous Concentration limits for aquatic species were exceeded in only three samples from sites 9 and 10 from 1988-99 (fig. 18). Increases in ammonia concentrations from site 6 to site 9 may be due to runoff of fertilizers in the urban area, discharges of at least small amounts of ammonia in treated municipal wastewater, and biological generation of ammonia in reducing zones in reservoirs (fig. 2, fig. 18). Decreased ammonia concentrations at site 10 may be due to uptake by algae and other aquatic plants in the river.

Concentrations of organic nitrogen, the sum of organic plus ammonia nitrogen, and the sum of nitrogen compounds increased in the downstream direction in the North Canadian River (figs. 19, 20, and 21). Sources for those increased concentrations may include: (1) runoff of fertilizers and animal wastes, (2) seepage from on-site septic systems, and (3) discharges of treated municipal wastewater.

The North Canadian River may be enriched with phosphorus (fig. 22), posing a threat of eutrophication. Most of the samples were not analyzed for total phosphorus, but 18 samples collected from 1988 to 1999 at site 10 had a median total phosphorus concentration of 0.49 milligram per liter. Median dissolved orthophosphate concentrations ranged from 0.05 milligram per liter at site 6 to 0.47 milligram per liter at site 10 (fig. 23). The median orthophosphate concentration for Mississippi River tributaries, by comparison, was 0.034 milligram per liter, and averaged 0.01 milligram per liter in undeveloped basins in the U.S. (table 4). As described in Fuhrer and others (1999), the greatest concentrations of nitrogen and phosphorus typically occur in streams draining agricultural and urban areas. Some of the phosphorus in the North Canadian River may be from natural soil runoff, but increases in phosphorus and orthophosphate concentrations as the river flows through the urban area probably are due to runoff of fertilizers, animal wastes, and discharges of treated wastewater to the river.

Concentrations of dissolved organic carbon, which has similar sources as organic nitrogen, but which also may be derived from industrial sources, were statistically similar at the four sites on the North Canadian River, with median concentrations ranging from 7.4 to 8.9 milligrams per liter (fig. 24).

\section{Trace Elements}

Trace element concentrations were analyzed in samples collected at sites $6,8,9$, and 10 . Some trace elements can be toxic to aquatic species and to humans. Trace elements detected in concentrations exceeding Oklahoma water-quality standards are described in the following paragraphs.

In the early 1990s, traditional USGS methods of collecting water-quality samples were determined to be inadequate for quantification of trace element concentrations (Windom and others, 1991, p. 11371142). Equipment-cleaning and sample-handling procedures were not always sufficient to prevent contamination of some samples by trace elements at microgram-per-liter concentrations. Improved protocols were developed and adopted by USGS in 1993; formal adoption of these procedures is documented by Horowitz and others (1994).

Graphs of several trace elements with time from the North Canadian River sites indicated no apparent step trend in the data around 1993-94, meaning that data collected prior to the new sample-collection protocols probably were not affected by the sampling process. More frequent detections of dissolved mercury and zinc in pre-1994 samples at concentra- 


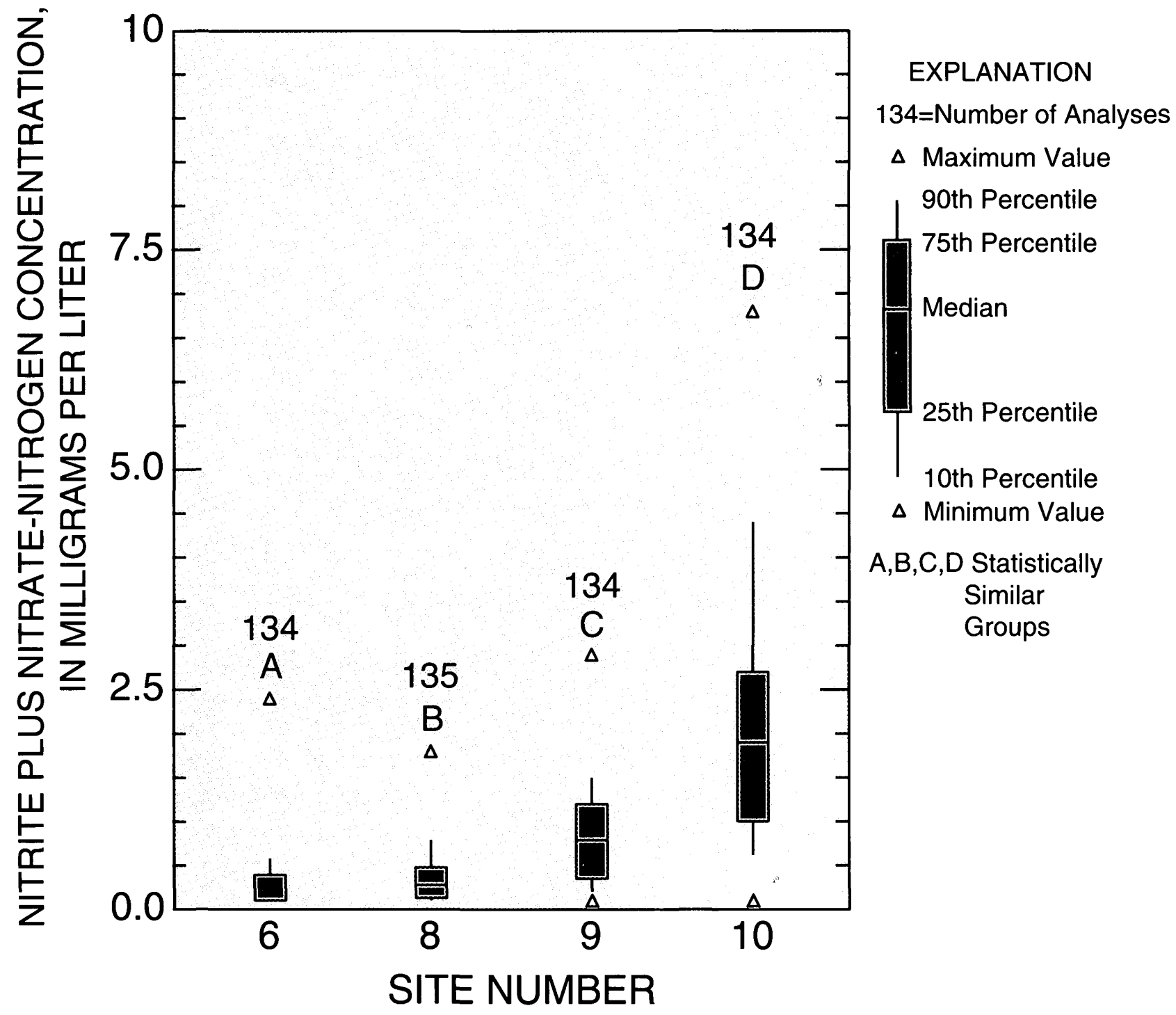

Figure 17. Nitrite plus nitrate-nitrogen concentration for selected sites on the North Canadian River, $1988-99$. 


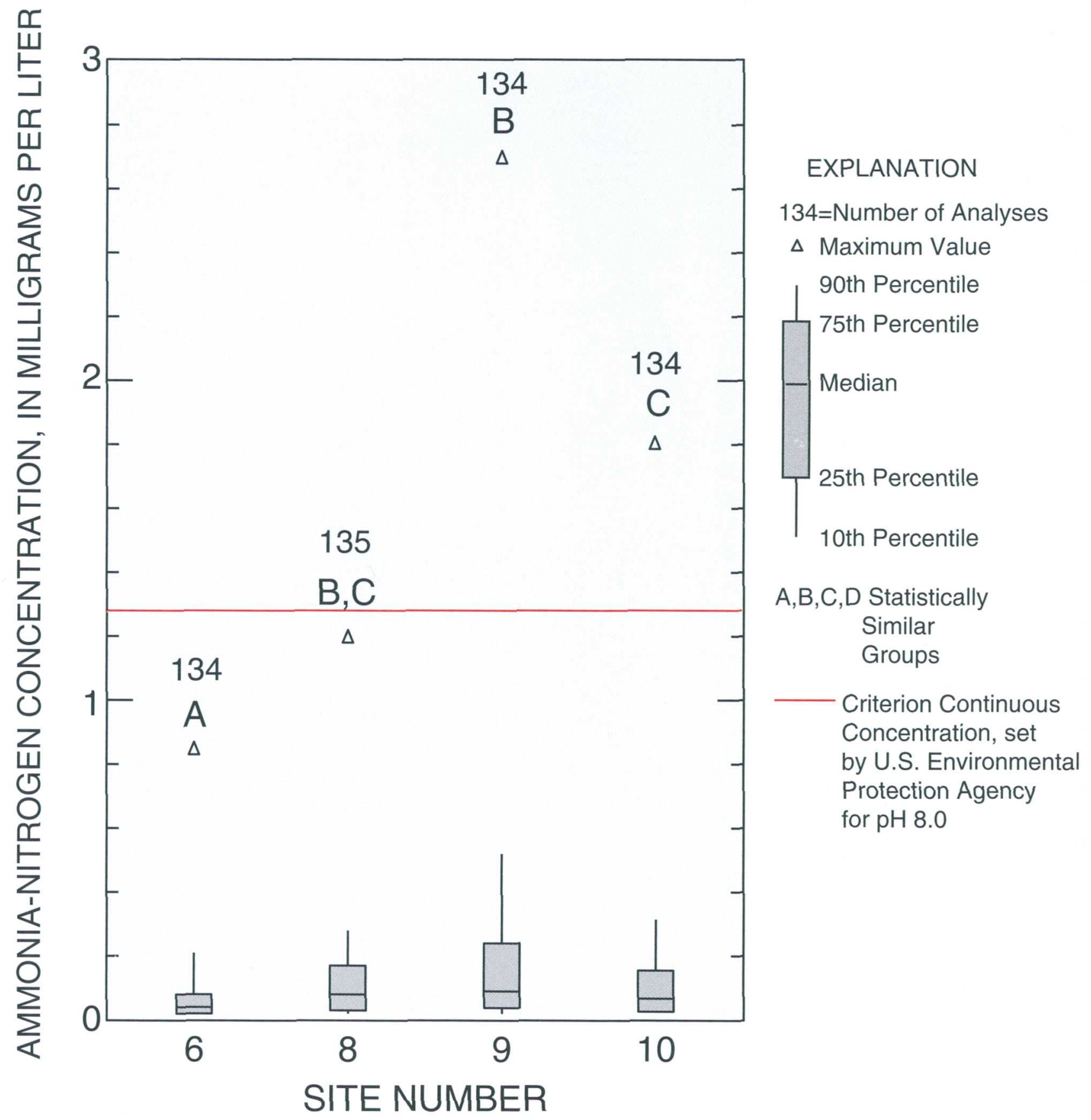

Figure 18. Ammonia-nitrogen concentration for selected sites on the North Canadian River, 1988-99. 


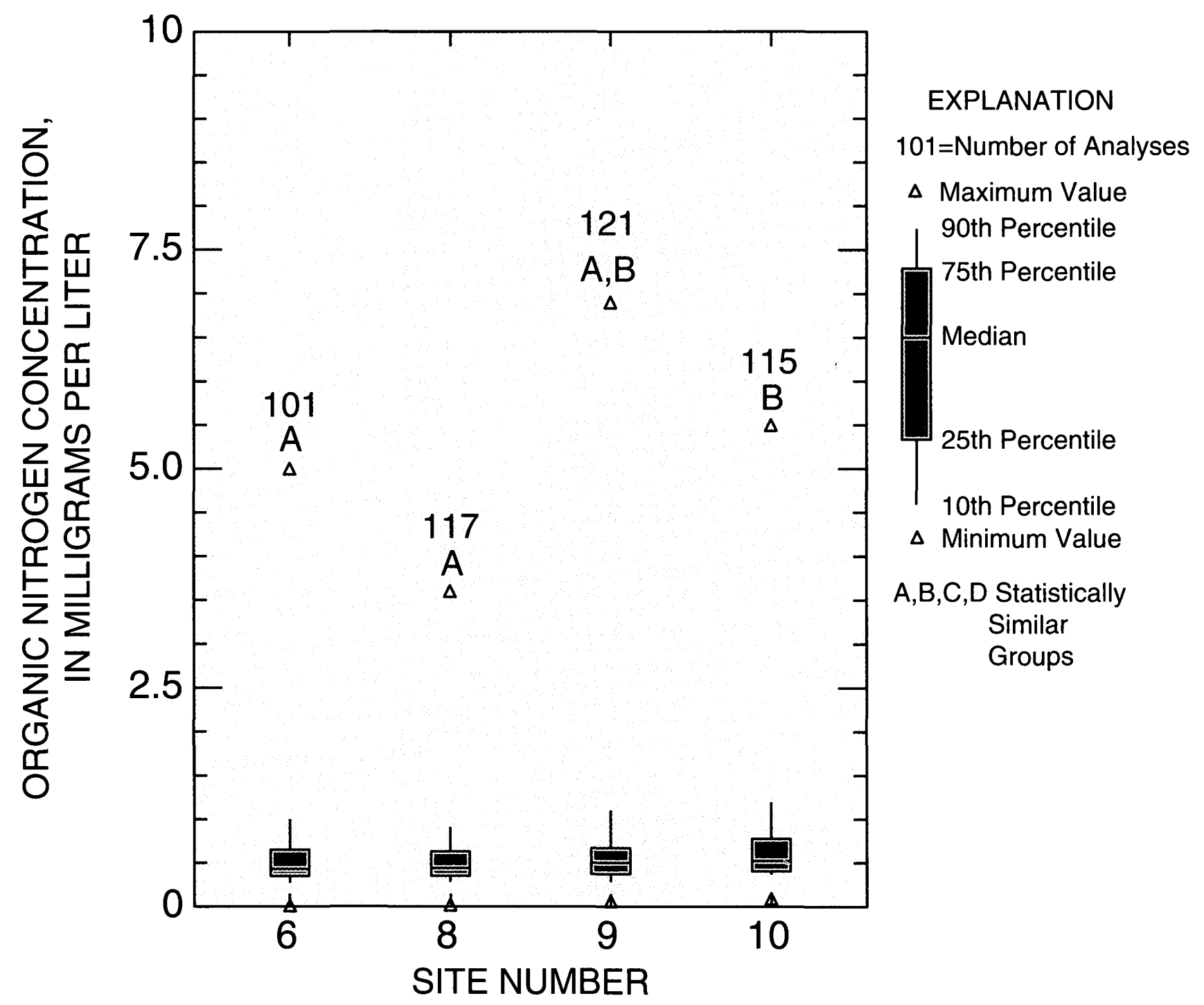

Figure 19. Organic nitrogen concentration for selected sites on the North Canadian River, 1988-99. 


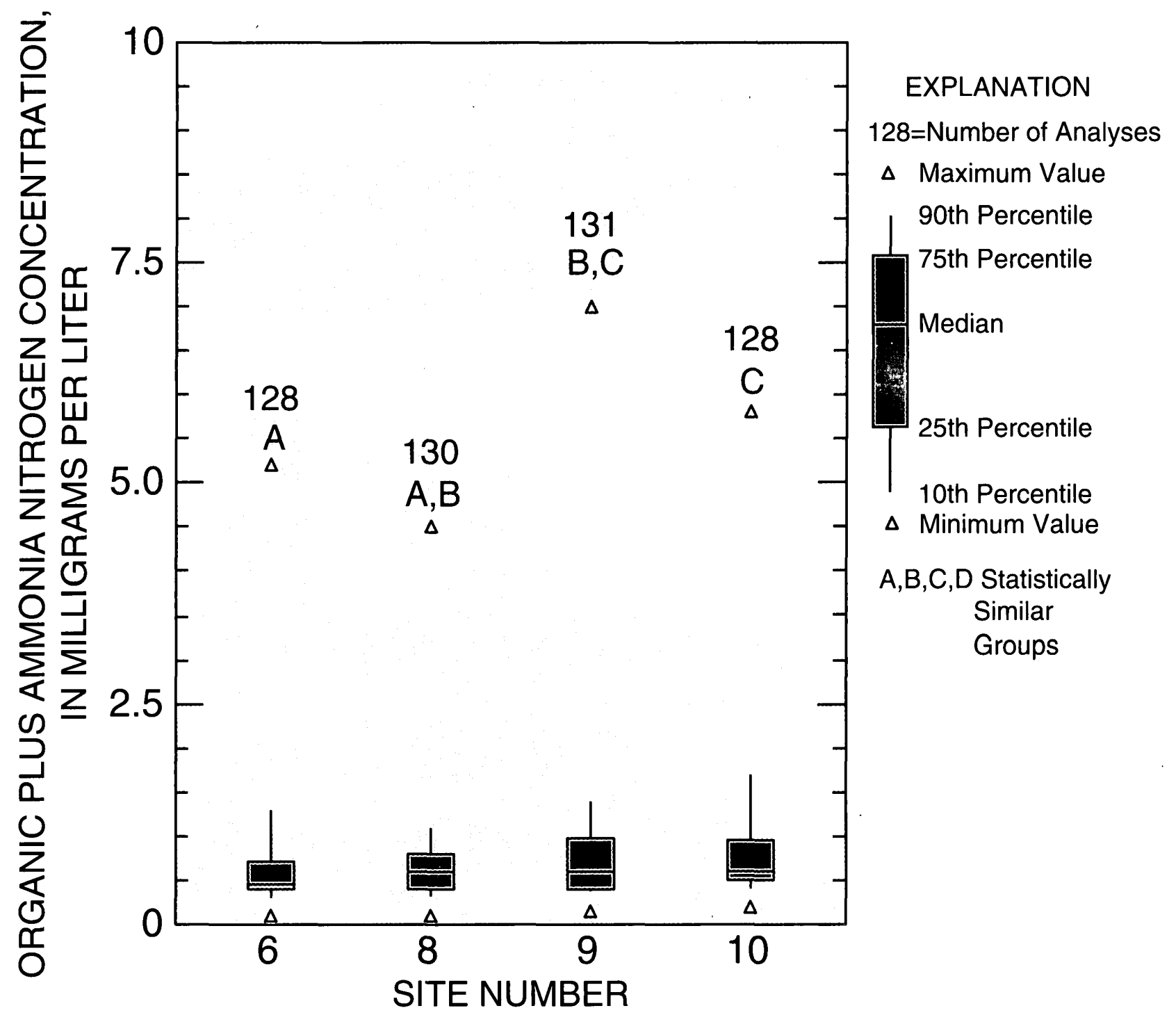

Figure 20. Organic plus ammonia-nitrogen concentration for selected sites on the North Canadian River, $1988-99$. 


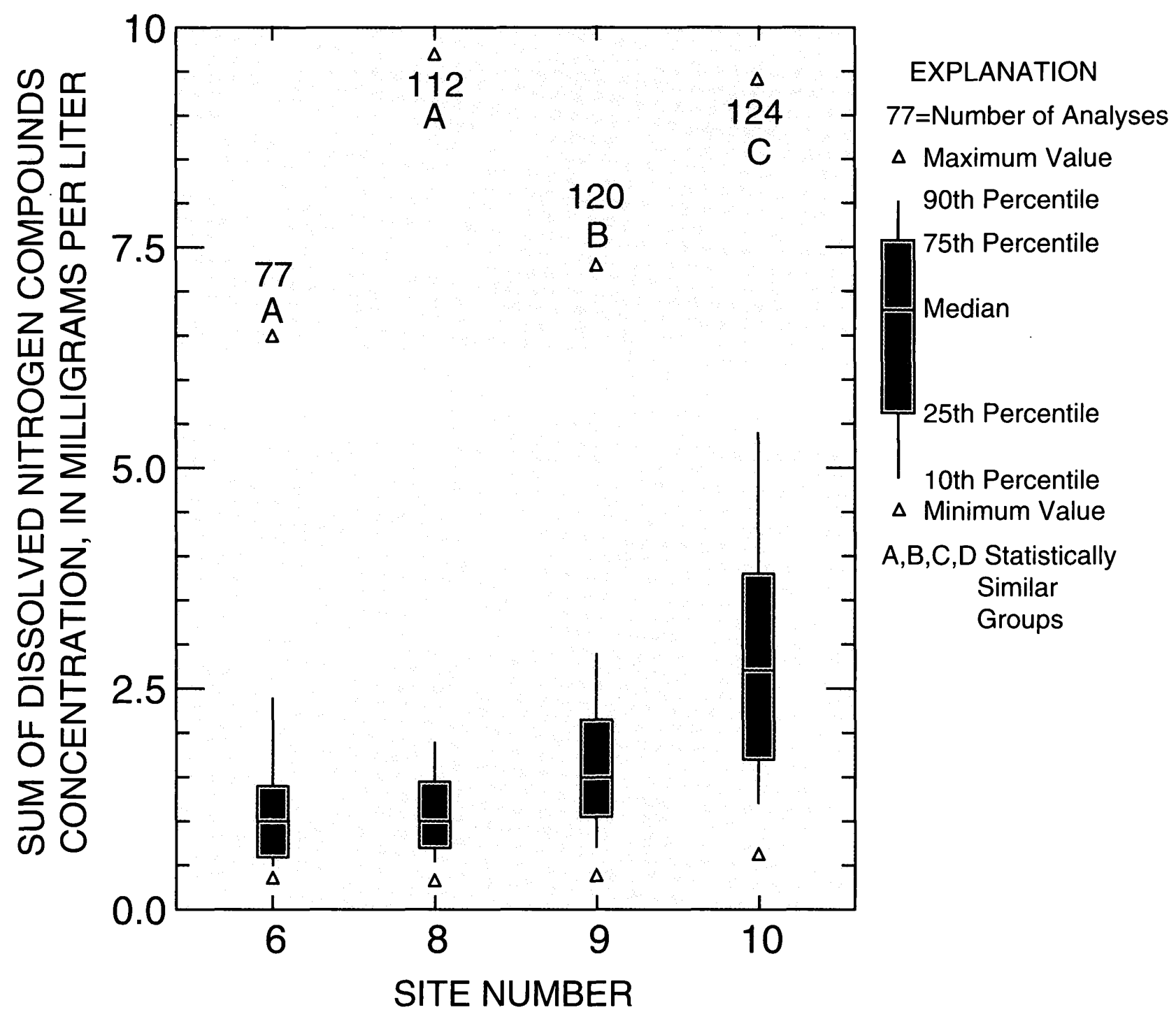

Figure 21. Sum of dissolved nitrogen compound concentration for selected sites on the North Canadian River, 1988-99. 


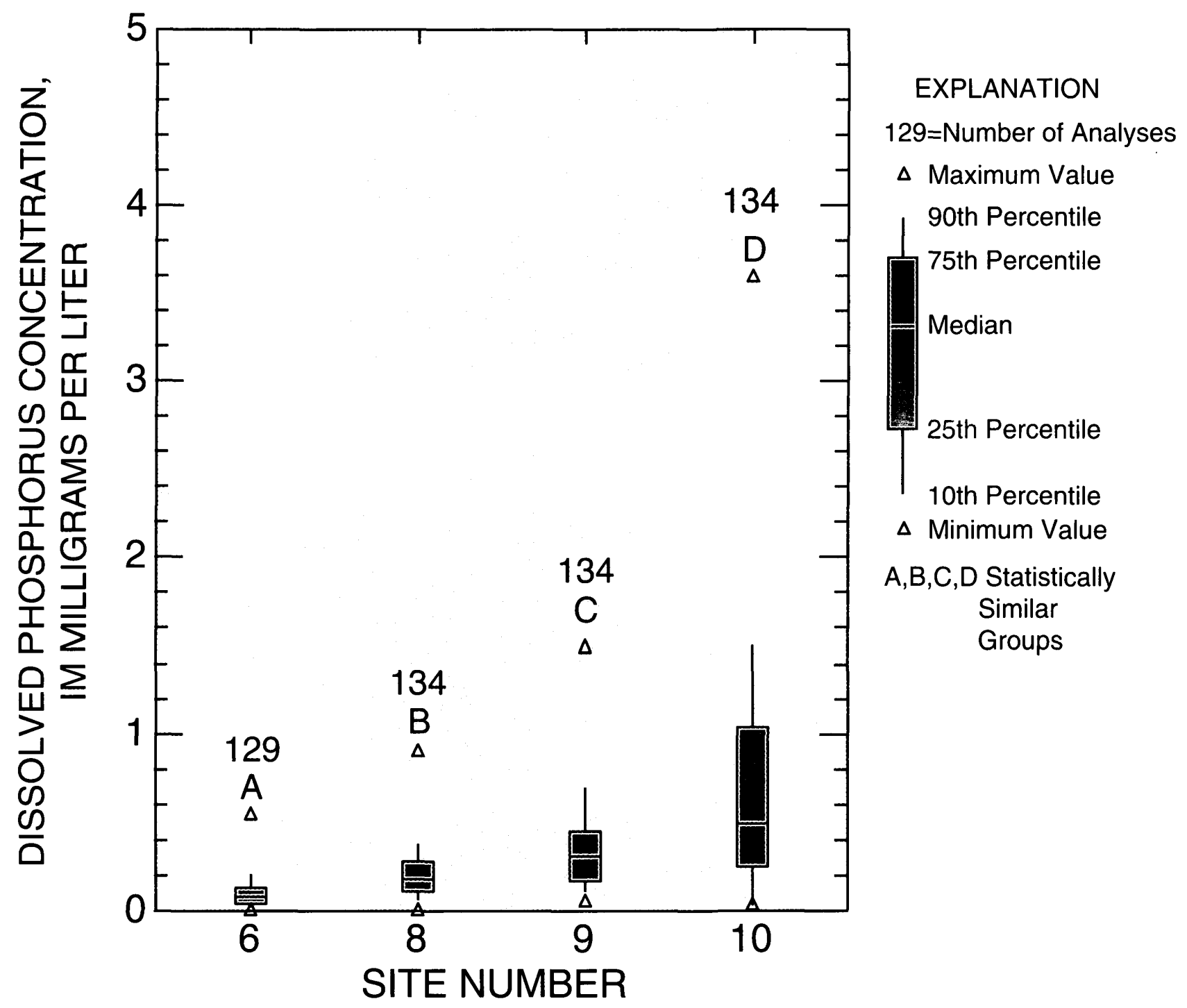

Figure 22. Dissolved phosphorus concentrations for selected sites on the North Canadian River, 1988-99. 


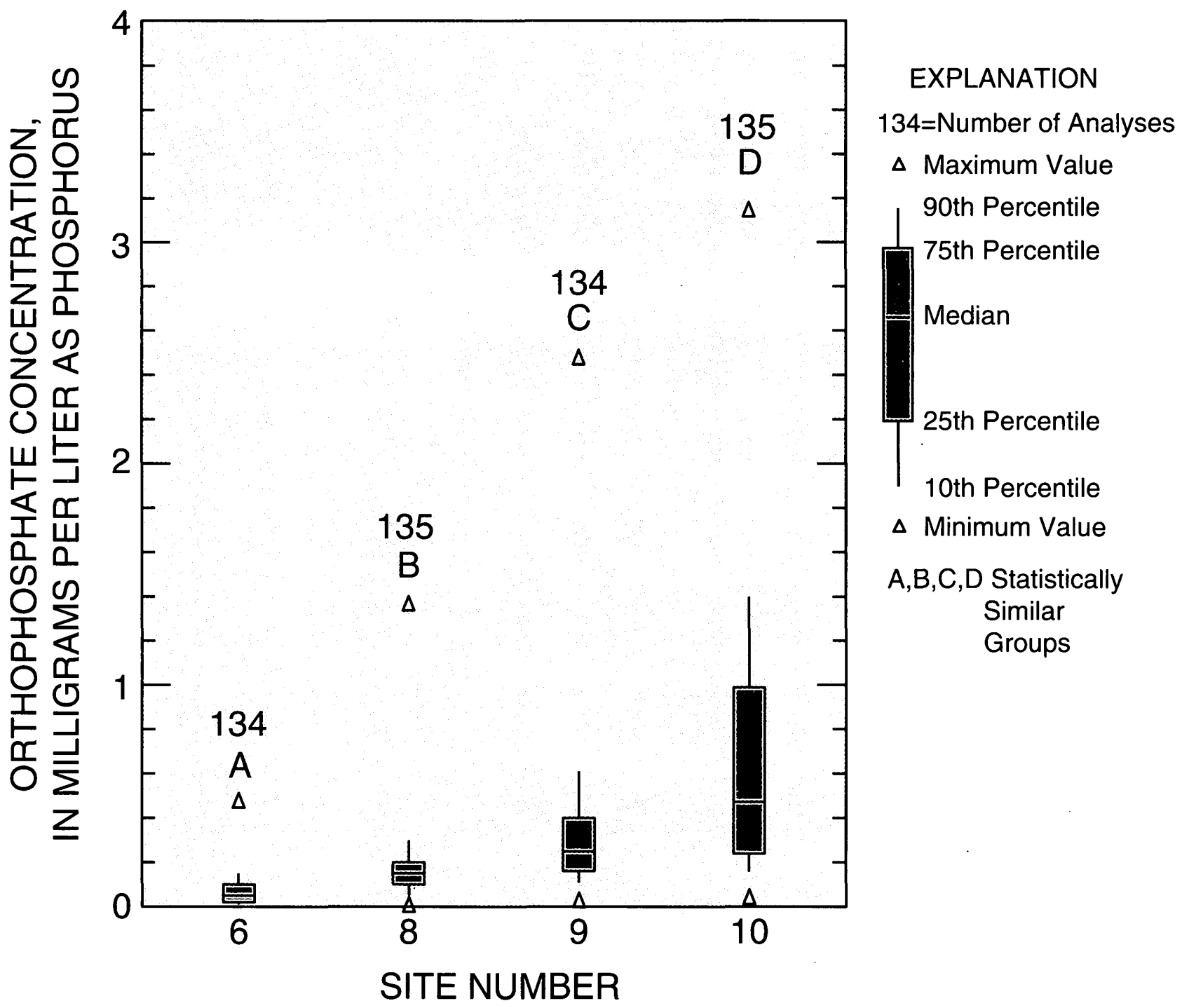

Figure 23. Orthophosphate-phosphorus concentration for selected sites on the North Canadian River, 1988-99. 


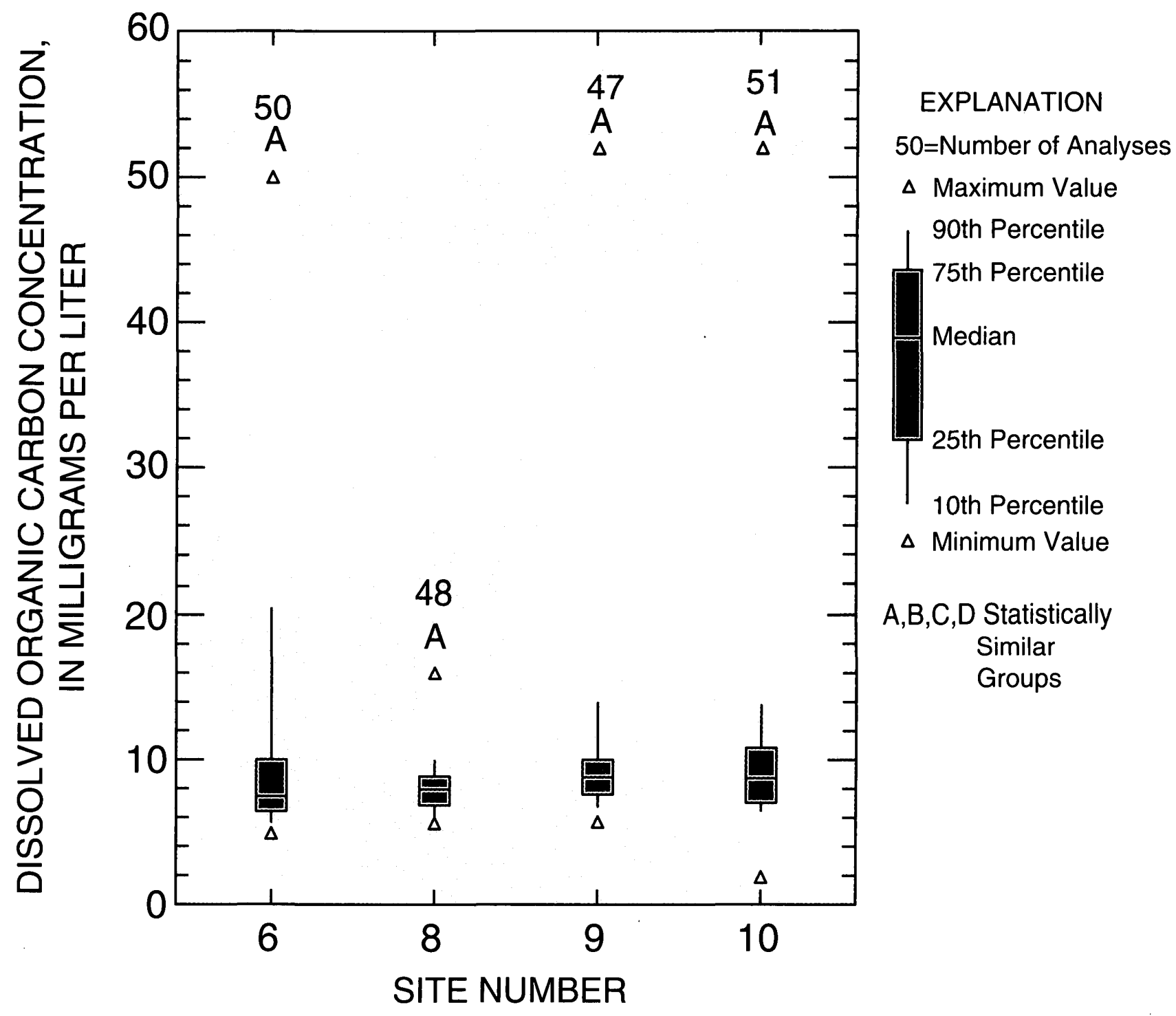

Figure 24. Dissolved organic carbon concentration for selected sites on the North Canadian River, 1988-99. 
tions much greater than those typically occurring in uncontaminated rivers (Shiller and Boyle, 1985, p. 4952; Babiarz and Andren, 1995, p. 173-183) may be related to sampling procedures or other sources of contamination in the shipping and analytical processes.

Manganese concentration increased at site 8, but decreased farther downstream (fig. 25). The increase in manganese concentration at site 8 may be related to mobilization of that element due to reducing conditions in parts of Lake Overholser, which is immediately upstream of that site. About 20 percent of the samples from site 8 and 15 percent of the samples from site 9 had concentrations of manganese exceeding the Secondary Maximum Contaminant Level (fig. 25), which is set primarily to avoid staining of laundry and plumbing fixtures, rather than health effects.

Mercury was detected in some samples at sites 6, 8, 9, and 10 (Appendix 2) The maximum concentration at site 10 (1.7 micrograms per liter) exceeded the Criterion Maximum Concentration of 1.4 micrograms per liter. However, these detections could be biased by sample contamination. The human health criterion set by the U.S. Environmental Protection Agency for mercury is 0.050 microgram per liter, which is half the detection limit used for most of the mercury data. Thus, exceedance of this criterion cannot be evaluated with these data.

Silver has a Criterion Maximum Concentration of 3.4 micrograms per liter (U.S. Environmental Protection Agency, 1976), which was exceeded in one sample from sites 9 and 10 (Appendix 2).

\section{Volatile Organic Compounds}

None of the 35 volatile organic compounds analyzed were detected in 10 water samples collected at sites 6 and 8 from 1988-90 (Appendix 2). Method reporting limits for those analyses were 3 micrograms per liter. Subsequent analyses of surface waters in urban areas of the U.S. by the USGS National WaterQuality Assessment Program, using analytical methods with lesser method reporting limits, have indicated the presence of numerous volatile organic compounds in urban streams (Stark and others, 2000; Anderson and others, 2000).

\section{Pesticides}

Sites 1, 3, 4, and 5 on Bluff, Deer, and Chisholm Creeks were sampled for 11 organophosphate pesticides, and site 2 was sampled for twelve pesticides (Appendix 1). Sites 6, 9, and 10 on the North Canadian River were sampled for pesticides including: (1) organophosphate insecticides, (2) amide herbicides, (3) phenoxy herbicides, (4) organochlorine insecticides, (5) anilide herbicides, (6) triazine herbicides, (7) hydroxyacid herbicides, (8) cyclodiene insecticides, (9) carbamate insecticides, and (10) other pesticides. The number of pesticide compounds analyzed in samples from those sites varied as follows: site 6 (62), site $8(50)$, site 9 (61), site 10 (62). The number of samples collected per site varied with pesticide type and ranged from less than 10 samples for some of the carbamate pesticides to 62 samples per site for some of the organophosphate pesticides (Appendices 1 and 2). Comparisons of pesticide concentrations between streams can be made for only organophosphate pesticides, which were analyzed in samples from Bluff, Deer, and Chisholm Creeks, and the North Canadian River. Of those compounds, only diazinon was detected at levels sufficient for comparison.

None of the pesticides were detected in concentrations exceeding Raw Water Numerical Criteria. Pesticide data were evaluated by examining frequencies of detection, ranges of reported concentrations, and spatial distributions of detections. Analytical results for pesticides also were compared to Oklahoma water-quality standards. Toxaphene concentration exceeded the Criterion Maximum Concentration of 0.73 microgram per liter in one sample each at sites 9 and 10 (U.S. Environmental Protection Agency, 1976). The concentration of toxaphene in those samples was 1.0 microgram per liter.

The most frequently-applied pesticides (fig. 26) were not necessarily the most frequently-detected pesticides in water samples (figs. 27, 28). Most pesticides sorb strongly to soil particles and also are broken down by bacteria and fungi in soils. Cropland pesticide use by county (fig. 26) also does not include the amounts of pesticides applied to urban and suburban lawns, which may be much greater on a pounds-peracre-per-year basis than agricultural applications of pesticides, due to lesser economic constraints on owners of small residential lots. 


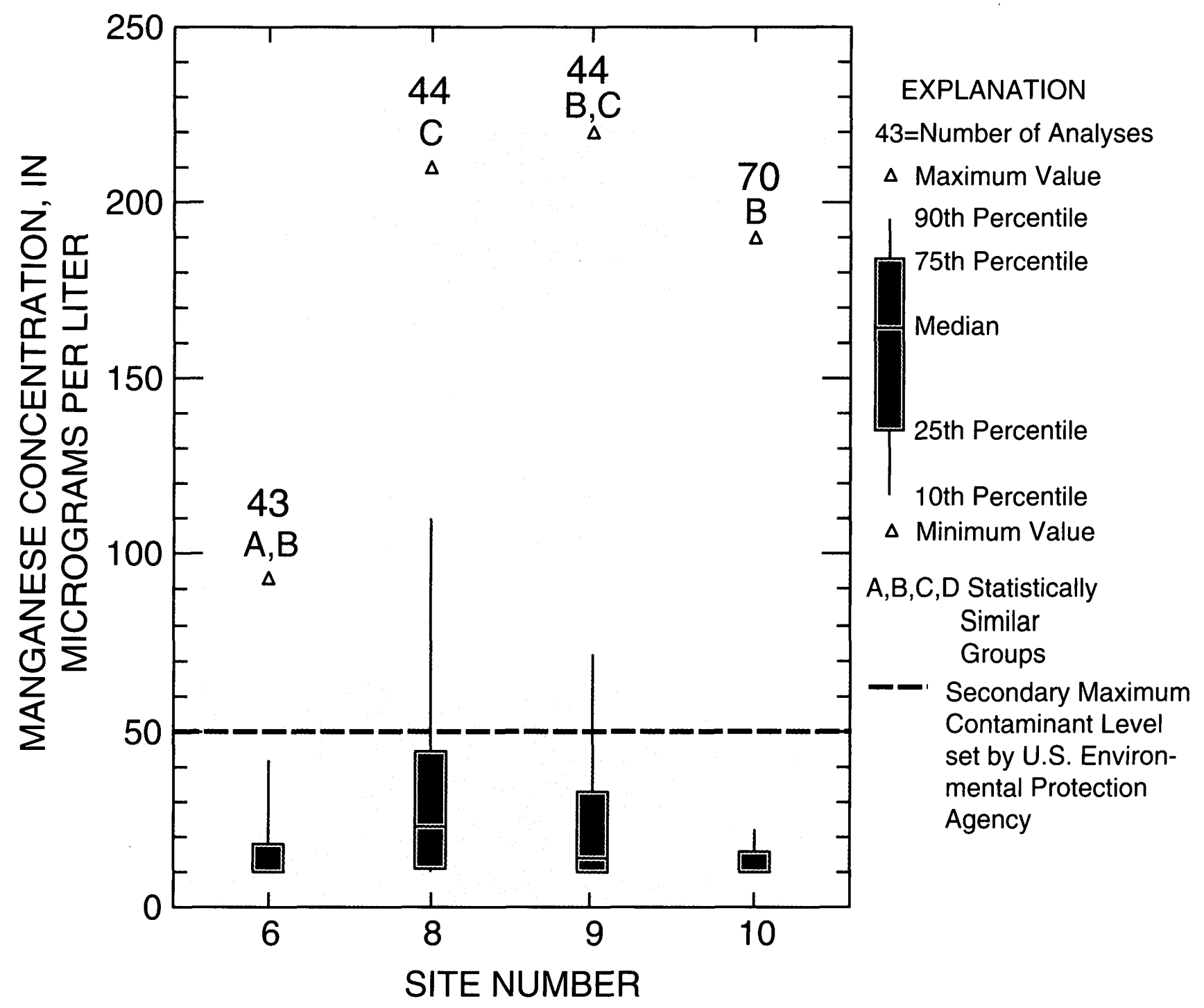

Figure 25. Manganese concentration for selected sites on the North Canadian River, 1988-99. 

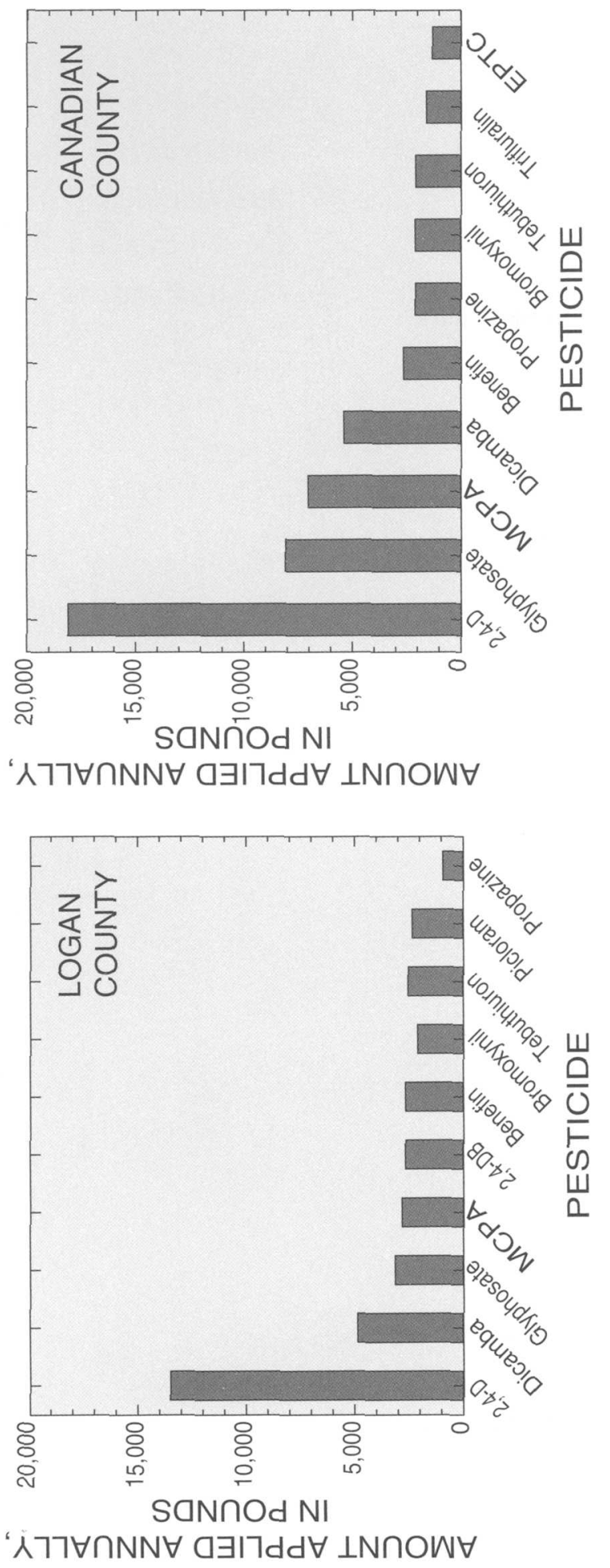

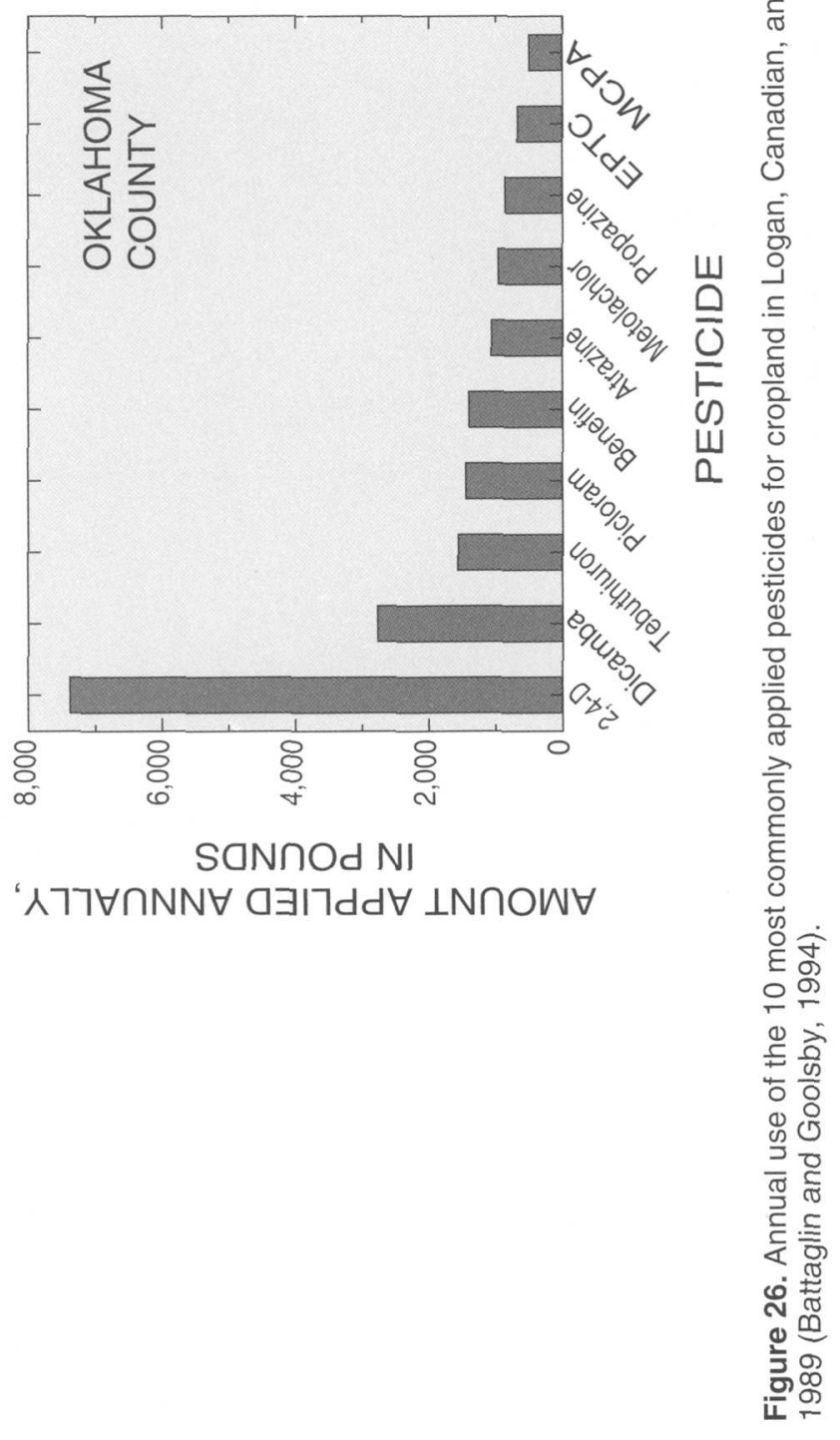




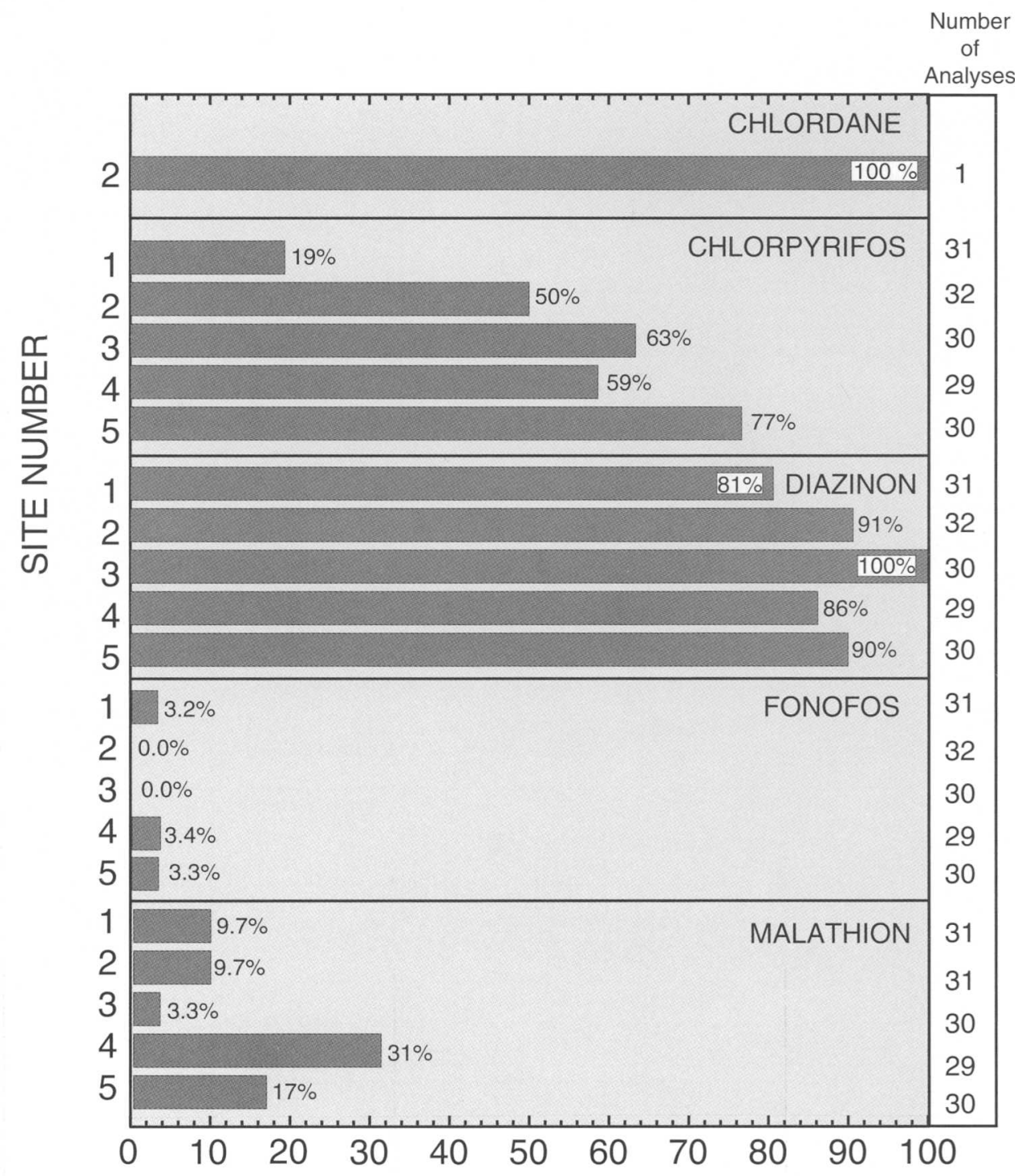

FREQUENCY OF DETECTION, IN PERCENT OF SAMPLES (ONLY COMPOUNDS WITH GREATER THAN 5 PERCENT FREQUENCY OF DETECTION IN ALL SAMPLES FROM THESE SITES ARE SHOWN)

Figure 27. Frequency of detection of pesticides for selected sites on Bluff, Deer, and Chisholm Creeks, 1993-99. 


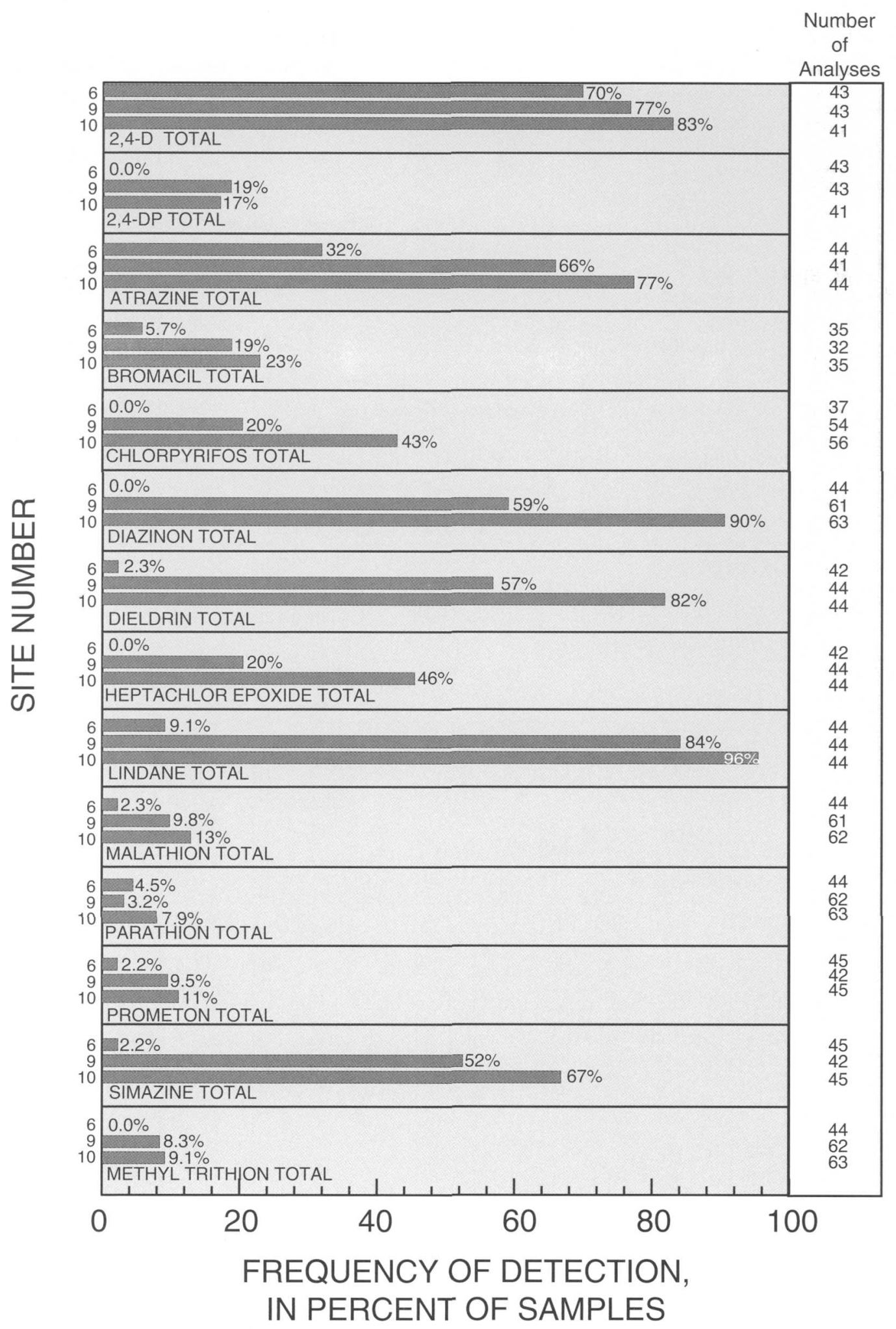

Figure 28. Frequency of detection of pesticides for selected sites on the North Canadian River, 1988-99. 
Fuhrer and others (1999, p. 10) reported somewhat similar data to those in this report; that the insecticides diazinon, carbaryl, chlorpyrifos, and malathion; and the herbicides atrazine, simazine, and prometon were the most commonly-detected pesticides in urban streams in 20 major basins of the Nation. 2,4-D, dieldrin, and lindane were also detected in most samples from sites 9 and 10 on the North Canadian River.

\section{Bluff, Deer, and Chisholm Creeks Sites}

Five of the 11 organophosphate pesticides analyzed in samples from the sites on these creeks were detected: chlordane, chlorpyrifos, diazinon, fonofos, and malathion (fig. 27, Appendix 1). Sample collection began in August 1993 and continued through September 1999.

Of these five sites, chlordane was detected only at site 2, where it was analyzed and detected in one sample (Appendix 1, fig. 27). Chlordane, a pesticide used on crops and lawns to control termites around fences and buildings, was registered for use from 1948 to 1988 (Agency for Toxic Substances and Disease Registry, 2001a).

Chlorpyrifos was detected in 19 to 77 percent of the samples at these five sites (Appendix 1, fig. 27), but was not detected at a concentration greater than 0.03 microgram per liter and the median concentrations for chlorpyrifos were at the method reporting limit (Appendix 1, fig. 29). Chlorpyrifos, also known as Dursban, is an organophosphorus pesticide used to control cockroaches, fleas, and termites; is used in some pet flea and tick collars, is used to control ticks on cattle; and is sprayed to control crop pests (Agency for Toxic Substances and Disease Registry, 2001b). Use of chlorpyrifos on cropland in Oklahoma County is estimated to be between 0.4 to 1.7 pounds per square mile per year (U.S. Geological Survey, 2001a). However, urban area use rates may be greater. The Numerical Criterion for Toxic Substances (Chronic) exposure standard for aquatic life is 0.041 microgram per liter (Oklahoma Water Resources Board, 2000). The frequency of detection and concentration of chlorpyrifos generally increased in the downstream direction for these creeks (Appendix 1).

Diazinon, which was detected in 81 to 100 percent of the samples from sites 1-5 (Appendix 1, fig. 27), also was present in greater concentrations than the other pesticides (Appendix 1). Diazinon is an organo- phosphorus pesticide used to control insects in soil, on ornamental plants, on fruit and vegetable field crops, and to control household pests such as flies, fleas, and cockroaches (Agency for Toxic Substances and Disease Registry, 2001c). Estimates of diazinon application to cropland in Oklahoma County range from 0.004 to 0.019 pound per square mile per year (U.S. Geological Survey, 2001b). Rates of use of this pesticide in urban areas are likely to be much greater.

Because of concerns about its toxicity for humans and wildlife, the U.S. Environmental Protection Agency has made an agreement for phasing out most uses of diazinon by the end of 2003 (U.S. Environmental Protection Agency, 2000).

One of 32 samples collected at site 2 had a diazinon concentration of 0.8 microgram per liter, exceeding the Lifetime Health Advisory Limit of 0.6 microgram per liter set by U.S. Environmental Protection Agency (1995). Maximum concentrations of diazinon ranged from 0.36 microgram per liter at site 5 to 0.80 microgram per liter at site 2 (Appendix 1, fig. 30). Concentrations of diazinon increased downstream in Bluff and Deer Creeks (sites 1-3, Appendix 1), but on Chisholm Creek (sites 4 and 5), diazinon concentrations generally decreased downstream (Appendix 1, fig. 30).

Fonofos, not one of the most commonly applied pesticides in the study area (fig. 26), was detected in less than 4 percent of the samples from sites 1,4 , and 5 , and was not detected in any of the samples collected at sites 2 and 3 (Appendix 1, fig. 27). Fonofos is an organophosphorus pesticide applied to soils to control insect pests that attack corn and turf grass.

Malathion was detected in 3.3 to 31 percent of the samples collected at the five sites on Bluff, Deer, and Chisholm Creeks (Appendix 1, fig. 27). Malathion is an organophosphorus pesticide used against a wide variety of insects in crops, lawns and gardens, and in homes. Use of malathion in Oklahoma County is greater than 1,228 pounds per square mile per year, in the highest category for the U.S. (U.S. Geological Survey, 2001c). Maximum malathion concentrations ranged from 0.10 microgram per liter at site 5 to 0.39 microgram per liter at site 1 (Appendix 1), but few samples had malathion concentrations exceeding the Numerical Criterion for Toxic Substances (Chronic) for aquatic organisms, set at 0.1 microgram per liter (Oklahoma Water Resources Board, 2000). 


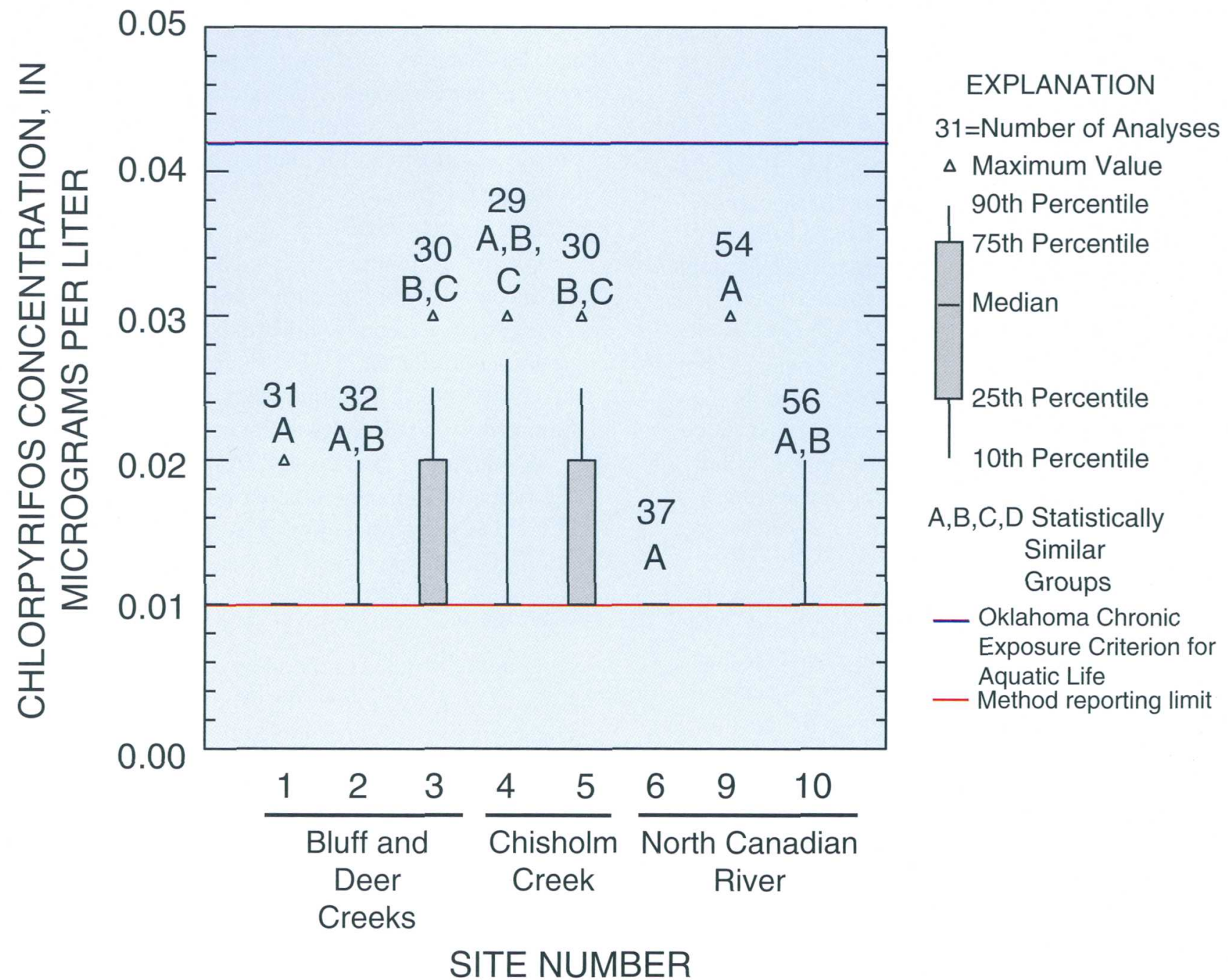

Figure 29. Chlorpyrifos concentration for selected sites on Bluff, Deer, and Chisholm Creeks (1993-99), and the North Canadian River (988-99). 


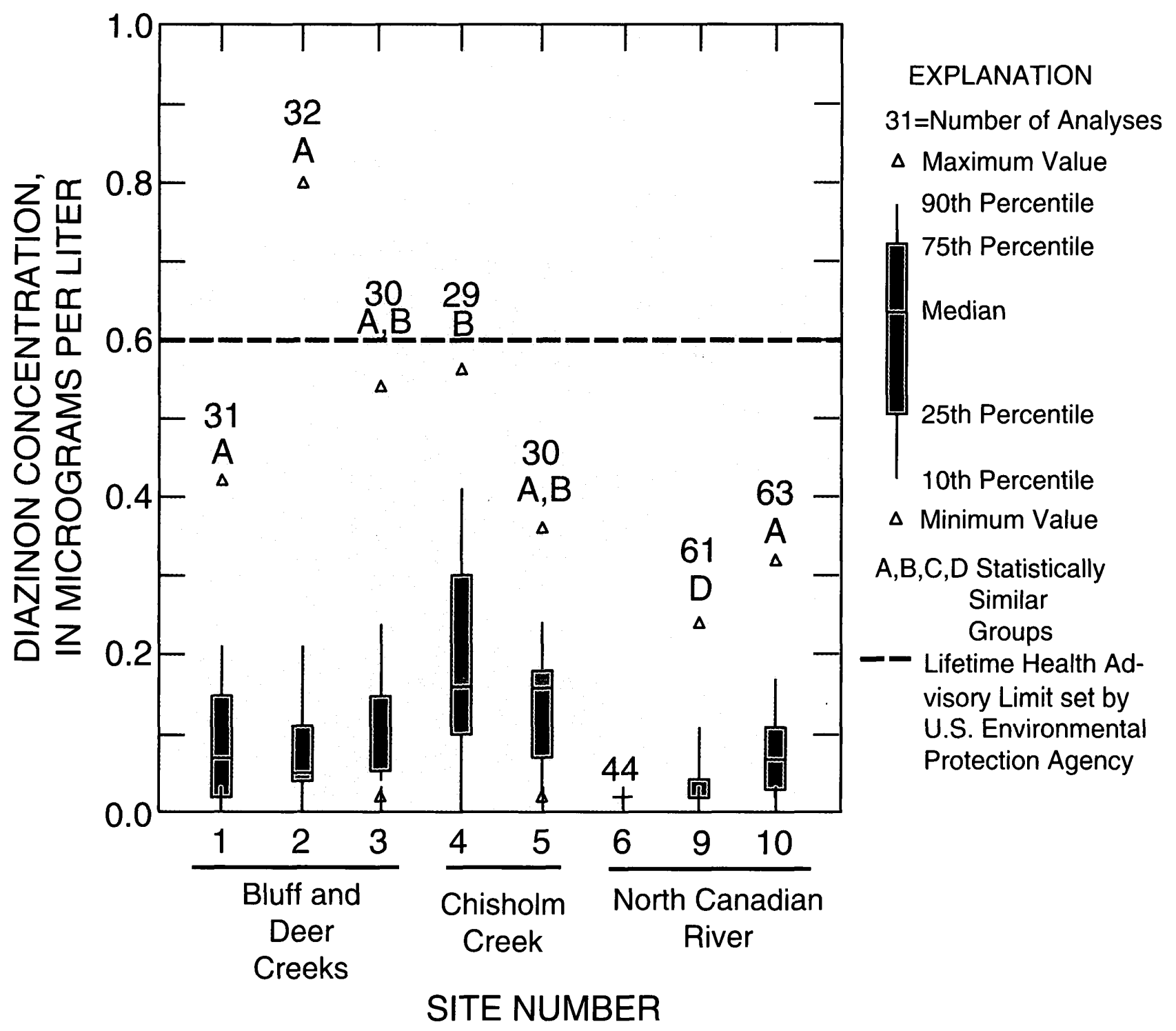

Figure 30. Diazinon concentration for selected sites on Bluff, Deer, and Chisholm Creeks (1993-99) and the North Canadian River (1988-99). 


\section{North Canadian River Sites}

A large suite of pesticides was analyzed quarterly in samples collected at sites 6, 9, and 10 on the North Canadian River from 1988-99. These pesticides also were analyzed once in a sample collected at site 8 on November 3, 1988 (Appendix 2).

Pesticide detection frequencies generally increased in a downstream direction (fig. 28). The North Canadian River accumulates increasing concentrations of pesticides as it flows through Oklahoma City (Appendix 2), which is consistent with application of these pesticides by urban and suburban landowners.

One of the most frequently detected pesticides at sites on the North Canadian River was the chlorophenoxy acid pesticide, 2,4-D, which was detected in 70 to 83 percent of the samples analyzed from sites 6, 9, and 10 (Appendix 2, fig. 28). 2,4-D has been used since 1946 to control weeds in wheat and small grains, sorghum, corn, rice, sugar cane, low-till soybeans, rangeland, pasture, rights-of-way, lawns, and to control aquatic weeds. 2,4-D is one of the most widely used pesticides in the United States, with cropland application estimates in 1989 of 13,470 pounds per year in Logan County; 18,124 pounds per year in Canadian County; and 7,380 pounds per year in Oklahoma County (fig. 26). 2,4-D concentrations increased from site 6 to sites 9 and 10 (Appendix 2, fig. 31) The maximum detected concentration of 2,4-D was 0.50 microgram per liter at site 9 (Appendix 2, fig. 31). The Oklahoma Raw Water Numerical Criterion for 2,4-D is 100 micrograms per liter.

The pesticide 2,4-DP (dichlorprop) was not detected at site 6 , but was detected in 19 percent of samples from site 9 and 17 percent of samples from site 10 (fig. 28). 2,4-DP is a phenoxy pesticide used to control weeds in forests, golf courses, and lawns (Information Ventures, Inc., 2001a). Rates of use of 2,4-DP in the study area is unknown. The maximum concentration of 2,4-DP was 0.30 microgram per liter at site 9 (Appendix 2).

Atrazine concentrations generally increased downstream, with a maximum concentration of 2 micrograms per liter being detected in a sample from site 10 (Appendix 2, fig. 32). Atrazine was detected in 32 percent of samples from site 6 , increasing to 66 percent of samples from site 9 and 77 percent of samples from site 10 (Appendix 2, fig. 28). Atrazine, used to kill broadleaf weeds in corn, sorghum, and conifer plantings, has been used in relatively small amounts in the study area, with annual cropland applications in 1989 of 230 pounds in Logan County, 851 pounds in Canadian County, and 1,059 pounds in Oklahoma County (Battaglin and Goolsby, 1994).Deethylatrazine, a metabolite of atrazine, was detected in one sample each from sites 6,9 , and 10 (Appendix 2).

Bromacil, a hydroxyacid pesticide used to control woody vegetation in non-cropland areas, was detected in about 6 percent of samples from site 6 , increasing to 23 percent of samples from site 10 (fig. 28). The maximum bromacil concentration was 1.2 micrograms per liter in a sample from site 6 (Appendix 2).

Chlorpyrifos was not detected at site 6 , but detection frequencies increased downstream to 20 percent of samples from site 9 and 43 percent of samples from site 10, indicating leaching of this organophosphorus pesticide from soils in the urban area (Appendix 2, fig. 28). Maximum chlorpyrifos concentrations were 0.03 microgram per liter at site 9 and 0.02 microgram per liter at site 10 (Appendix 2, fig. 29), less than the Numerical Criterion for Toxic Substances (Chronic) exposure standard for aquatic life of 0.041 microgram per liter (Oklahoma Water Resources Board, 2000).

Diazinon was not detected at site 6, but the frequency of detection increased markedly downstream to 59 percent of the samples from site 9 and 90 percent of the samples from site 10 (fig. 28).

Maximum concentrations of diazinon were 0.24 microgram per liter at site 9 and 0.32 microgram per liter at site 10 (Appendix 2, fig. 30)-far less than the Lifetime Health Advisory Limit set by the U.S. Environmental Protection Agency (fig. 30). Diazinon concentrations at site 10 were similar to those from sites 1, 2, and 3, in Bluff and Deer Creeks (fig. 30).

The frequency of detection of dieldrin increased downstream in the North Canadian River, from 2.3 percent of samples from site 6 to 82 percent of samples from site 10 (fig. 28). Dieldrin, a cyclodiene pesticide, was used to control insects in crops such as corn and cotton from 1950-1970. The U.S. Environmental Protection Agency banned use of dieldrin in 1974 except to control termites and in 1987, the U.S. Environmental Protection Agency banned all use of this pesticide (Agency for Toxic Substances and Disease Registry, 2001d). 


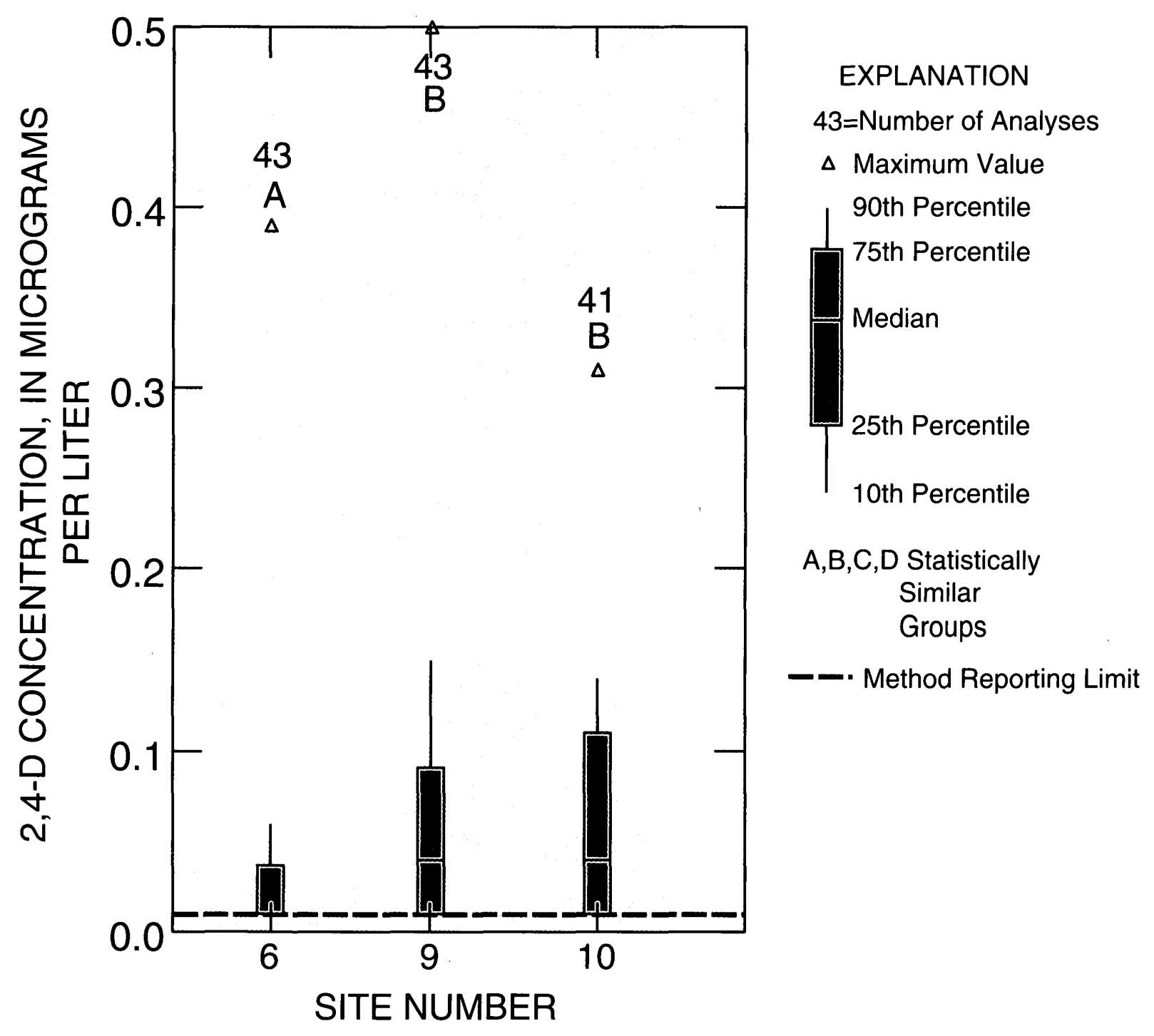

Figure 31. 2,4-D concentration for selected sites on the North Canadian River, 1988-99. 


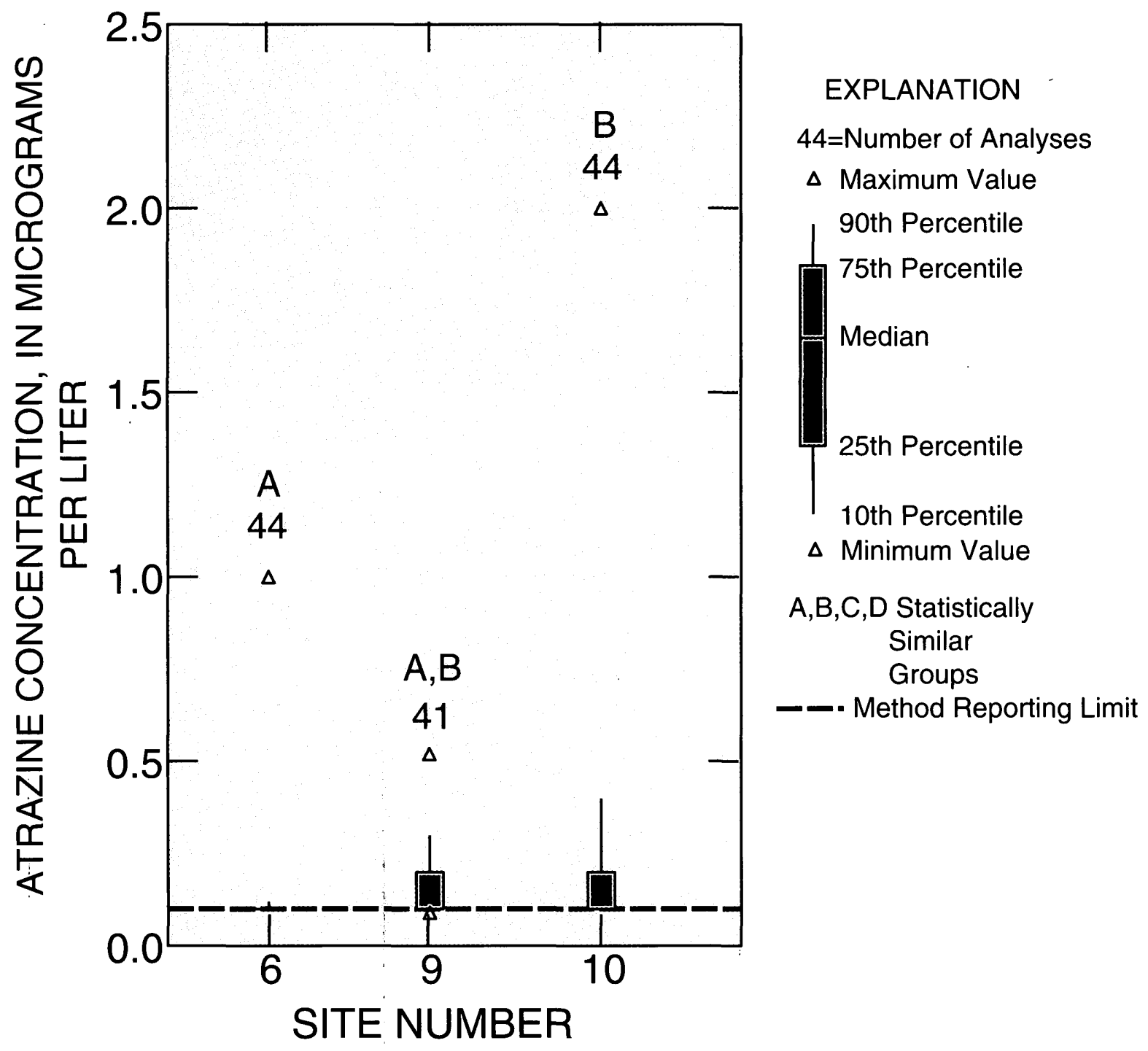

Figure 32. Atrazine concentration for selected sites on the North Canadian River, 1988-99. 
Increased frequency of detection of dieldrin in the North Canadian River as it flows through the urban area may be due to its use as a termiticide. The maximum detected dieldrin concentration was 0.007 microgram per liter in a sample from site 10 (Appendix 2). The Oklahoma Water Column Criterion to Protect for the Consumption of Fish Flesh and Water specifies a limit of 0.0014 microgram per liter of dieldrin (Oklahoma Water Resources Board, 2000).

Heptachlor epoxide was not detected in samples from site 6 , but was detected in 46 percent of samples from site 10 (fig. 28). Heptachlor was used extensively for killing insects in homes, buildings, and on food crops, especially corn. Use slowed in the 1970's and stopped in 1988 (Agency for Toxic Substances and Disease Registry, 2001e). The maximum concentration of heptachlor epoxide was 0.004 microgram per liter in a sample from site 10 (Appendix 2). The Oklahoma Water Column Criterion to Protect for the Consumption of Fish Flesh and Water specifies a limit of 0.0021 microgram per liter for heptachlor, the parent compound of heptachlor epoxide (Oklahoma Water Resources Board, 2000). The Oklahoma Numerical Criterion for Toxic Substances for heptachlor is 0.52 microgram per liter (acute) and 0.0038 microgram per liter (chronic) (Oklahoma Water Resources Board, 2000).

Lindane was one of the most frequently detected pesticides in the North Canadian River, with frequencies of detection increasing from 9.1 percent in samples from site 6 to 96 percent of samples from site 10 (fig. 28). Lindane is an organochlorine pesticide used to control a wide range of soil-dwelling and plant-eating insects. It commonly is used on a wide variety of crops, in warehouses, to control insect-borne diseases, and as a seed treatment. Lindane also is used in lotions, creams, and shampoos for the control of lice and mites on humans (Oregon State University, 2001).

Lindane concentrations and frequencies of detection increased substantially as the North Canadian River flowed through the urban part of the study area (figs. 28, 33). The maximum lindane concentration was 1.0 microgram per liter in a sample from site 9 (fig. 33). Only that sample had a lindane concentration exceeding the Oklahoma Water Column Criterion to protect for the Consumption of Fish Flesh and Water (0.1458 microgram per liter) or the Oklahoma Water Column Criterion to Protect for the Consump- tion of Fish Flesh (0.4908 microgram per liter) (Oklahoma Water Resources Board, 2000).

Malathion was detected in 2.3 percent of samples from site 6 , increasing to 13 percent of the samples from site 10 (fig. 28). The maximum detected concentration of malathion was 0.16 microgram per liter in one sample from site 9 (Appendix 2), exceeding the Oklahoma Numerical Criterion for Toxic Substances limit of 0.10 microgram per liter (Oklahoma Water Resources Board, 2000).

The frequency of detection of parathion decreased from 4.5 percent at site 6 to 3.2 percent at site 9 , increasing to 7.9 percent of the samples collected at site 10 (fig. 28). Parathion is a broad spectrum, organophosphate pesticide used to control many insects and mites on fruit, cotton, wheat, vegetables, and nut crops. The maximum detected concentration of parathion at those three sites was 0.01 microgram per liter (the method reporting limit) (Appendix 2), which did not exceed the Oklahoma Criterion for Toxic Substances limit for this compound of 0.065 microgram per liter (acute) and 0.013 microgram per liter (chronic) (Oklahoma Water Resources Board, 2000).

Prometon was detected in 2.2 percent of samples from site 6 , with the frequency of detection increasing to 11 percent of samples from site 10 (fig. 28). Prometon is used to control broadleaf and grassy weeds around buildings, storage areas, fences, roadways, railroads, recreation areas, lumberyards, noncropland areas on farms, and rights-of-way (U.S. Forest Service, 2001). The maximum concentration of prometon was 0.60 microgram per liter in a sample from site 10 (Appendix 2).

Simazine was detected in 2.2 percent of the samples from site 6 , but the frequency of detection of that compound increased to about 67 percent of the samples from site 10 (fig. 28). Simazine is a triazine pesticide used to control broadleaf and grass weeds in nursery plantings and forestry; and as a nonselective pesticide for vegetation control in non-croplands, such as rights-of-way (Information Ventures, Inc., 2001b). Simazine applications in the study area are relatively small; Battaglin and Goolsby (1994) estimated annual cropland applications of simazine in 1989 to be 12 pounds in Logan County, 9 pounds in Canadian 


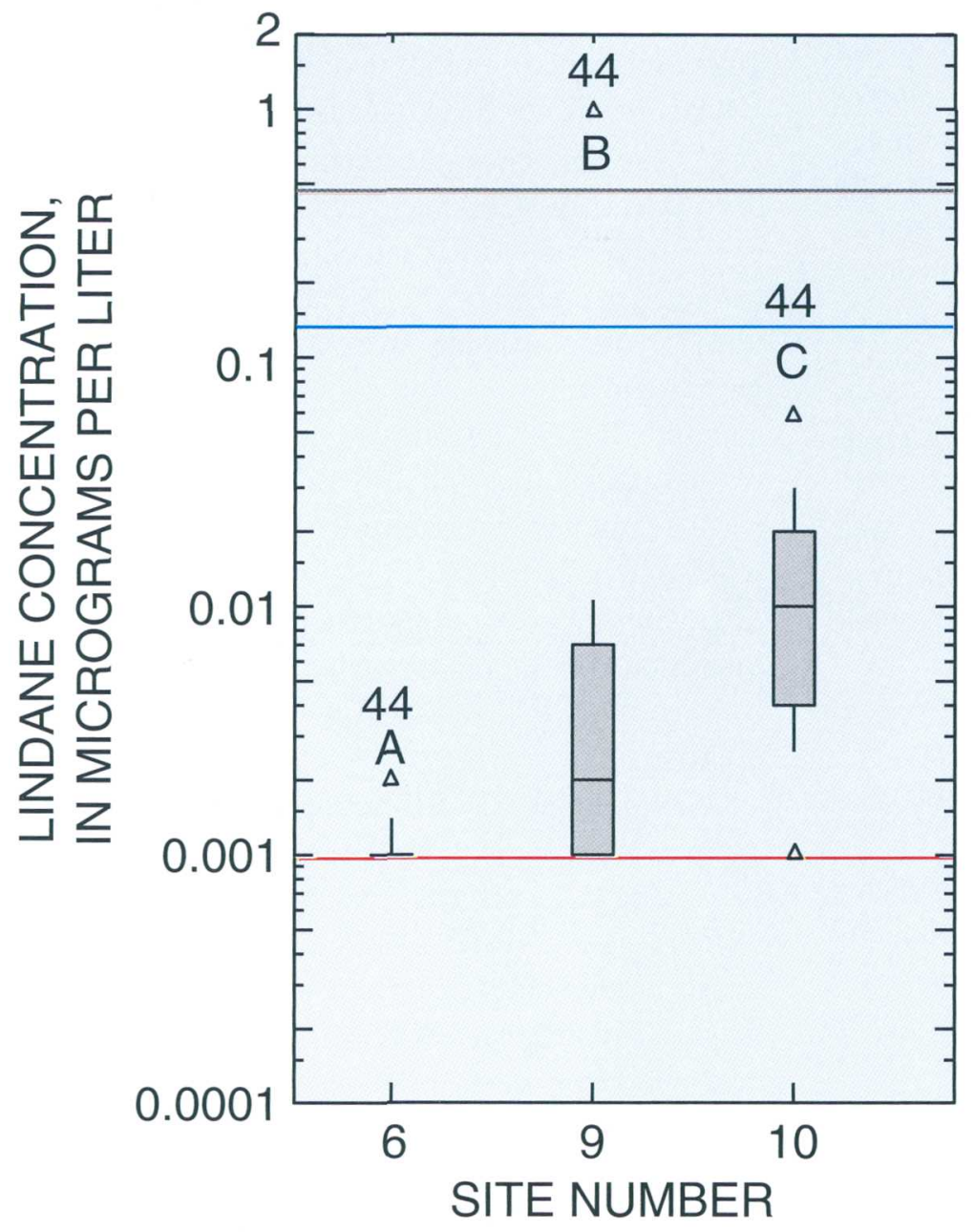

\section{EXPLANATION}

$44=$ Number of Analyses

$\Delta$ Maximum Value

90th Percentile

75th Percentile

Median

$\bigcup_{\text {10th Percentile }}$ 25th Percentile

$\Delta$ Minimum Value

A,B,C,D Statistically

Similar

Groups

Method Reporting Limit

Oklahoma Raw Criterion to

Protect for the Consumption of Fish Flesh and Water Oklahoma Raw Criterion to Protect for the Consumption of Fish Flesh

Figure 33. Lindane concentration for selected sites on the North Canadian River, 1988-99. 
County, and 26 pounds in Oklahoma County. The maximum simazine concentration was 1.1 micrograms per liter at site 10 (Appendix 2). The Maximum Contaminant Level for simazine is 4 micrograms per liter (U.S. Environmental Protection Agency, 1995). Methyl trithion was detected in increasing frequency as the North Canadian River flowed through Oklahoma City, ranging from no detections at site 6 to being detected in 9.1 percent of samples from site 10 (fig. 28). Methyl trithion is an organophosphate pesticide registered for use on a wide variety of vegetable, fruit, nut, forage, ornamental, and forestry sites (Cornell University, 2001). The maximum concentration of methyl trithion detected was 0.01 microgram per liter at sites 9 and 10 (Appendix 2).

Bed sediment samples also were analyzed for organochlorine pesticides at site 6 (Appendix 2). p, $p$ 'DDE was detected in 2 of 42 samples and $p, p^{\prime}$-DDT was detected in 1 of 42 samples. 2,4-D; 2,4,5-T; silvex (2,4,5-TP); ethion; malathion; parathion; diazinon; methyl parathion; ethyl trithion; and methyl trithion were not detected in bed sediment samples from site 6 (Appendix 2).

\section{Fecal-Indicator Bacteria}

Water samples were analyzed for the presence of fecal coliform bacteria at sites 6, 8, 9, and 10; median fecal coliform bacteria colony counts increased substantially between site 6 and site 8 (Appendix 2, fig. 34). The Oklahoma Primary Contact standard of 200 colonies per 100 milliliters was exceeded in more than 25 percent of samples collected at site 6 and in more than 50 percent of samples from sites 8,9 , and 10 (fig. 34). That standard, however, is based on the 30-day geometric mean of at least 5 samples, rather than single values. Downstream of site 8 , median bacteria counts remained elevated, with counts from site 10 significantly greater than counts from sites 6 and 8, perhaps due to discharges of treated municipal wastewater or to animals on the river corridor.

\section{Algal Indicators}

The following indicators of algae were analyzed in water samples collected approximately monthly at site 10 from 1987-96: chlorophyll- $a, b$, and $c$ in phytoplankton; pheotophytes; phytoplankton; and seston (Appendix 2). Chlorophyll- $a$ in phytoplankton is perhaps the most common indicator of algal biomass or eutrophication of a water body. Algae are typically most productive during the warmer summer months.

Chlorophyll- $a$ concentrations at site 10 increased with greater water temperatures, peaking at water temperatures of approximately 25 degrees Celsius (fig. 35). Chlorophyll- $a$ concentrations generally decreased little during the period of sampling at site 10 (fig. 35).

Carlson's Trophic State Index based on chlorophyll- $a$ (Carlson, 1977) was determined for waterquality from site 10 using the following equation to determine if water at that site was impaired by nutrients:

Trophic State Index $=30.6+9.81(\ln$ (chlorophyll $-a$, in micrograms per liter))

Most of the water samples collected at site 10 during that period had chlorophyll- $a$ concentrations that produced Trophic State Indices exceeding 62 (fig. 35 ), indicating that the North Canadian River was impaired by nutrients at that site during that period (Oklahoma Water Resources Board, 2002).

\section{CONSTITUENT TRENDS}

Continuous streamflow data were collected for all sampling sites on the North Canadian River by stream gages operated in cooperation with the City of Oklahoma City. Continuous streamflow data were not collected at sites 1-5, therefore, time trends in streamflow could not be analyzed with any reliability.

Trends described in this section for the North Canadian River sites are significant regressions (pvalues for regression coefficients less than 0.05 ) for streamflow, time, and season, and only for regression models judged to be "good" or "fair," as described in the methods section and the headnote of Appendix 3. Significant correlations and models judged "good" or "fair" are shaded in Appendix 3. Major ion, nutrient, and other water-quality constituent data collected from 1988-99 were evaluated for sites 6, 8, 9, and 10 .

For the period 1988-99, Kendall's tau test (Kendall, 1975) and locally-weighted estimated scatterplot smoothing (LOWESS; Cleveland and McGill, 1984; Cleveland, 1985) indicated significant 


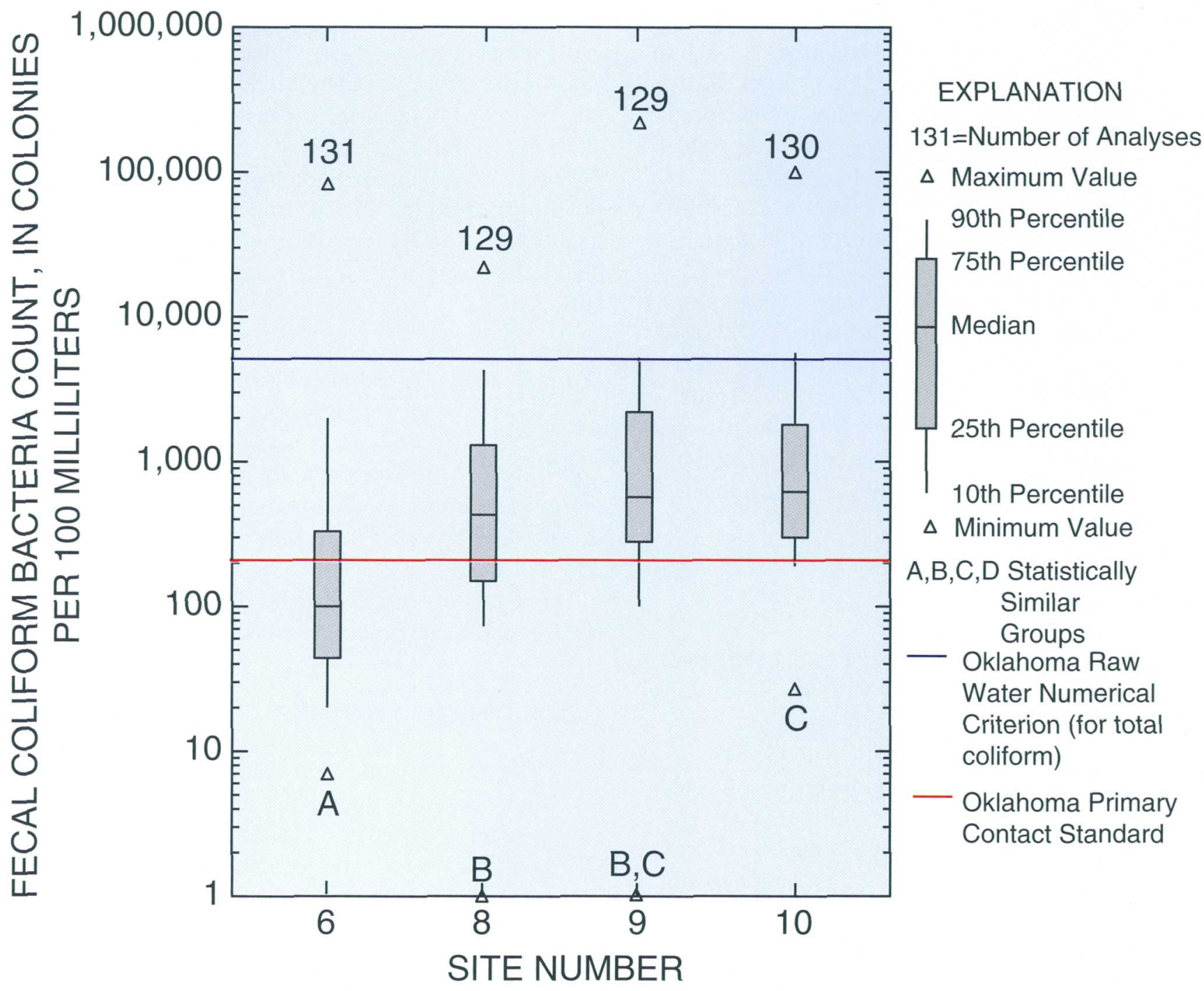

Figure 34. Fecal coliform bacteria count for selected sites on the North Canadian River, 1988-99. 

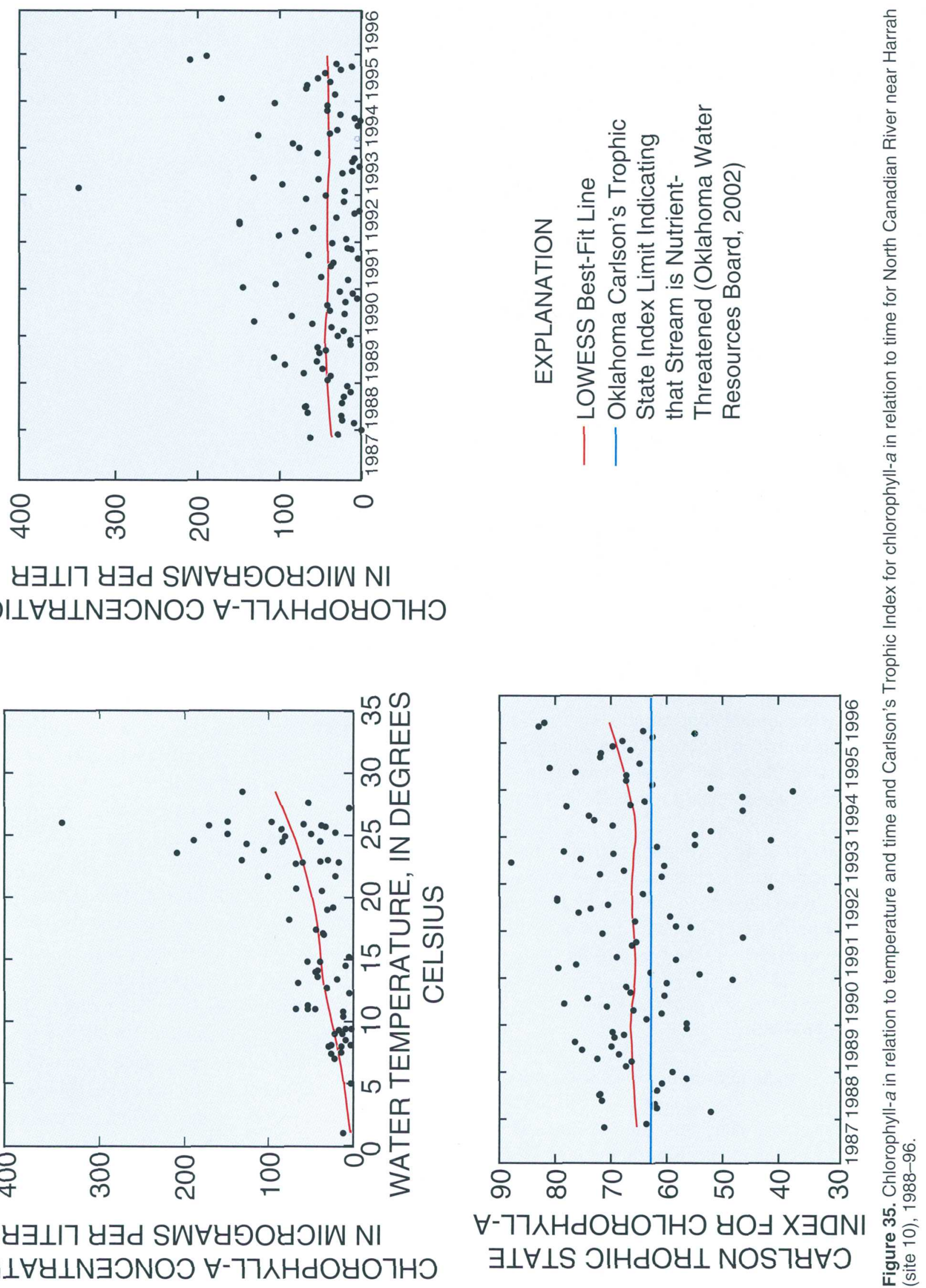
Table 5. Trends in mean monthly streamflow at sites on the North Canadian River near Oklahoma City, Oklahoma, 1988-99

\begin{tabular}{lccc}
\hline \multicolumn{1}{c}{ Station name (and station number) } & Site number & Kendall's tau & One-sided p-value \\
\hline North Canadian River near Calumet, Oklahoma (07239450) & 6 & 0.235 & 0.0000314 \\
North Canadian River near El Reno, Oklahoma (07239500) & 7 & 0.247 & 0.0000130 \\
$\begin{array}{l}\text { North Canadian River below Lake Overholser near Oklahoma } \\
\text { City, Oklahoma (07241000) }\end{array}$ & 8 & 0.230 & 0.0000453 \\
$\begin{array}{l}\text { North Canadian River at Britton Road at Oklahoma City, } \\
\text { Oklahoma (07241520) }\end{array}$ & 9 & 0.177 & 0.00132 \\
North Canadian River near Harrah, Oklahoma (07241550) & 10 & 0.161 & 0.00303 \\
\hline
\end{tabular}

increasing trends in monthly mean streamflow at all of the sites $(6,7,8,9$, and 10$)$ on the North Canadian River (table 5, fig. 3). Therefore, temporal trends in water-quality constituent concentrations for these sites should be considered in the context that changes in streamflow, rather than other factors, may be an important influence on water-quality trends (Helsel and Hirsch, 1992).

Calculation of flow-weighted concentrations, by modeling concentration versus streamflow at sites with stream gages, is an alternative means of evaluating effects of discharge trends on concentration trends. That approach was beyond the scope of this report.

\section{Water Properties}

Specific conductance in samples from site 10 generally decreased with increasing streamflow (fig. 36). Site 10 has the greatest amount of upstream urban area, so the reduction in specific conductance with increased streamflows may be due to the effect of urban runoff that has less dissolved solids content relative to the dissolved solids content of the river at lesser stream flows.
Log-transformed turbidity increased with increasing streamflow at sites 8,9 , and 10 (Appendix 3). Seasonal trends were indicated at site 8 , where logtransformed turbidity was greatest during June, and at sites 9 and 10 where log-transformed turbidity was greatest during July, perhaps due to algal growth and runoff from summer thunderstorms with resultant resuspension of bed sediments.

Dissolved oxygen concentration and log-transformed dissolved oxygen concentration generally decreased with increasing streamflow at sites 6,8 , and 10 (Appendix 3, fig. 37). Dissolved oxygen concentrations can decrease when oxygen-demanding substances are washed into streams by runoff. This phenomenon may be demonstrated at site 6 by significant increases in biochemical oxygen demand with increasing streamflow. Another possible cause of this relation is algal photosynthesis. When large amounts of runoff enter the river, algal density is temporarily reduced, potentially reducing photosynthetic production of oxygen. Photosynthesis also can be reduced when turbid runoff decreases light penetration into the water column. 


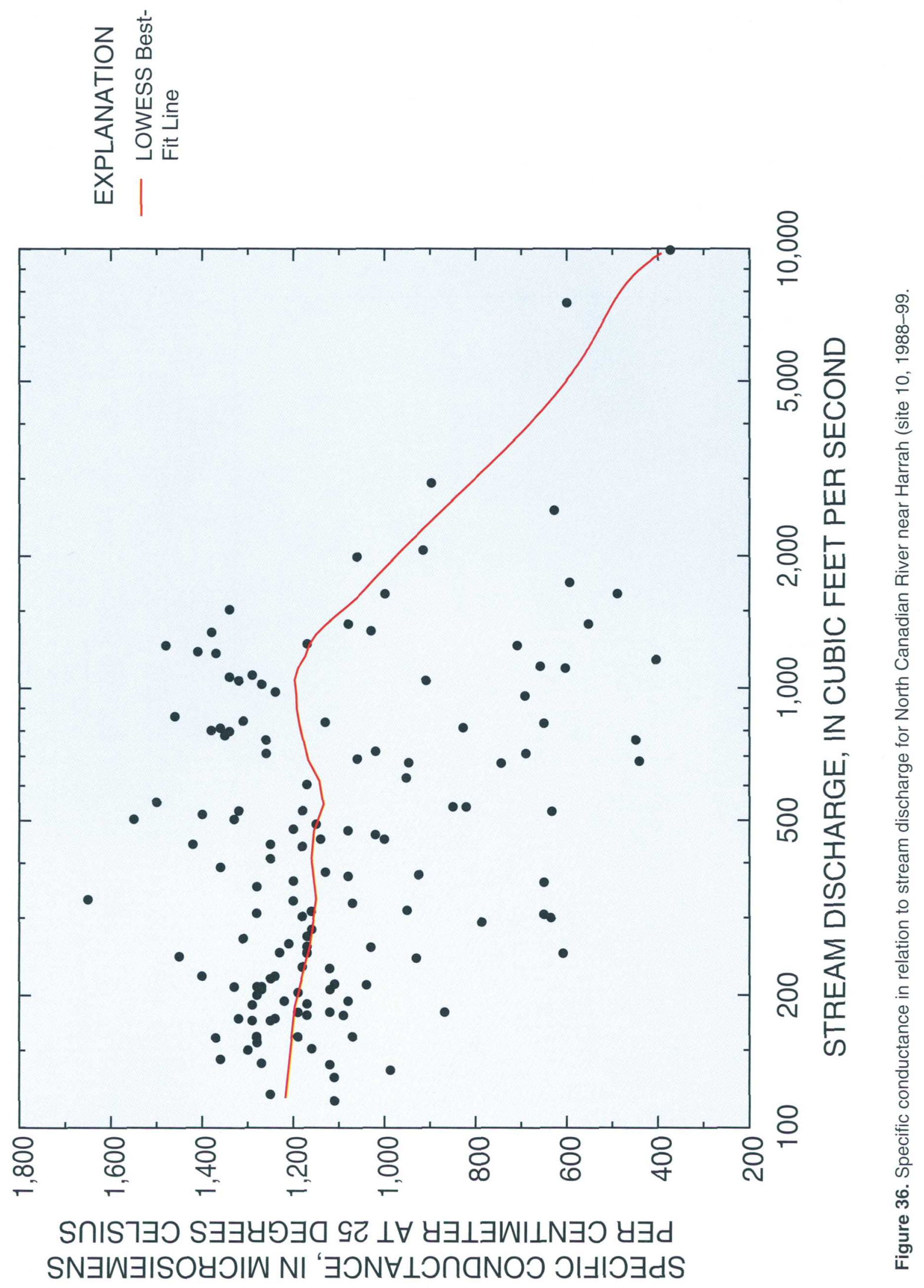




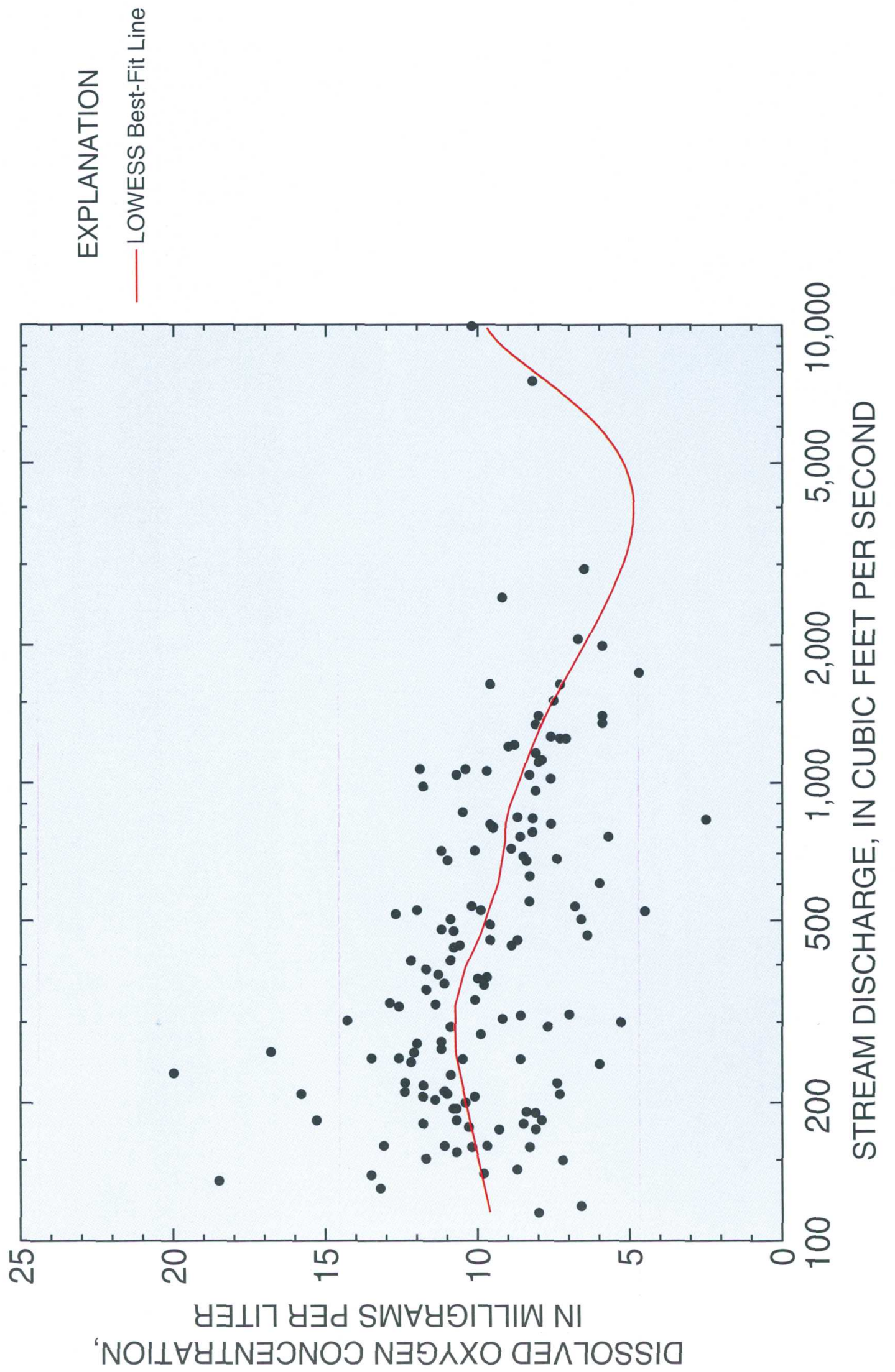

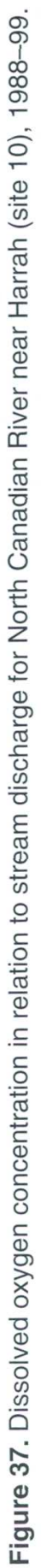


A long-term significant increase in dissolved oxygen concentration with time occurred at site 10 . The amount of increase, 0.0968 milligram per liter per year, is about 1 percent of the median concentration (9.6 milligrams per liter) for the period (Appendix 3).

Samples from sites $6,8,9$, and 10 have significant seasonal trends of dissolved oxygen concentration or the logarithm of that concentration, with maximum values during January or February, probably due to greater solubility of oxygen in water at lower temperatures and lesser biochemical oxygen demand from algae and microbes. Saturation of dissolved oxygen also was greatest in the late fall/winter period at all sites except site 10 , where the peak in dissolved oxygen saturation occurred in June, possibly due to algal photosynthesis during daylight sampling events.

Log-transformed biochemical oxygen demand, indicative of the presence of organic compounds or reduced metals, significantly increased with time at sites 6,9 , and 10. The upward trends in biochemical oxygen demand at these sites increased, as percentages of median concentrations, in the downstream direction as follows: 6.4 percent per year at site 6,11 percent per year at site 9 , and 13 percent per year at site 10 (Appendices 2 and 3 ).

Seasonal trends were indicated for site 6 where log-transformed biochemical oxygen demand was greatest during July and at sites 9 and 10 where biochemical oxygen demand was greatest during June (Appendix 3). Greater biochemical oxygen demands during summer are likely to be related to algal biomass. Increasing biochemical oxygen demand with time may indicate increasing eutrophication with time at those three sites.

Log-transformed total solids concentration significantly increased with increasing streamflow at sites 6,8 , and 9 and also increased with time at site 8 at a rate of 3 milligrams per liter per year (Appendix $3)$. Seasonal trends were indicated for total solids concentration at site 6 and 8 , where concentrations were greatest during June, and at site 9 where concentrations were greatest during July, similar to the related property turbidity.

Dissolved solids concentration significantly decreased with streamflow at site 10 (Appendix 3). Dissolved solids concentration at site 10 also was seasonal, with an annual peak in February (Appendix $3)$.

\section{Major lons}

At site 8, calcium concentrations were seasonally greatest during February (Appendix 3), perhaps due to reduced uptake by terrestrial plants and algae in the river during the winter.

Trends in log-transformed potassium concentration occurred with streamflow, with a significantly positive relation at site 8 and significantly negative relation at site 10 , perhaps reflecting dilution by urban runoff at the downstream site 10 . Untransformed potassium concentration also had a negative correlation with streamflow at site 10 . At site $6, \log$-transformed potassium concentration and untransformed potassium concentrations decreased with time at a rate of 0.14 milligram per liter or 2.3 percent of the median value per year. At sites 8,9 , and 10 the log-transformed and untransformed concentrations of potassium were significantly seasonal, with annual peaks in August for sites 8 and 9 and in September for site 10 (Appendix 3).

Sulfate concentration increased with increasing streamflow and time at site 10 (Appendix 3, fig. 38). The trend of sulfate concentration with time was 5.16 milligrams per liter per year, or 3.2 percent per year of the median sulfate concentration (160 milligrams per liter) during the reporting period (Appendices 2 and 3 ). Lack of time trends of sulfate concentration at upstream sites indicates that site 10 may be affected by point- or nonpoint-source contributions of sulfate that enter the North Canadian River downstream of site 9, such as wastewater outfalls, runoff of concrete dust and fertilizers, petroleum production by-products, or increases of atmospheric concentrations of sulfurous compounds.

Chloride concentration has decreased with time at sites 6, 9, and 10 (Appendix 3, fig. 39). The magnitude of change, about 6-10 milligrams per liter per year, when compared to median chloride concentrations at those sites, $160-180$ milligrams per liter, is relatively large. Expressed as percentages of median chloride concentrations during the reporting period, chloride concentration decreased 5.6 percent per year at site $6,4.0$ percent per year at site 9 , and 3.8 percent per year at site 10 (Appendices 2 and 3). Chloride may be associated with natural seepages of brines or from disposal of waste brines from petroleum production. Decreases in chloride concentrations with time may be due to dilution from increased streamflow, decreased petroleum production, and better management with 


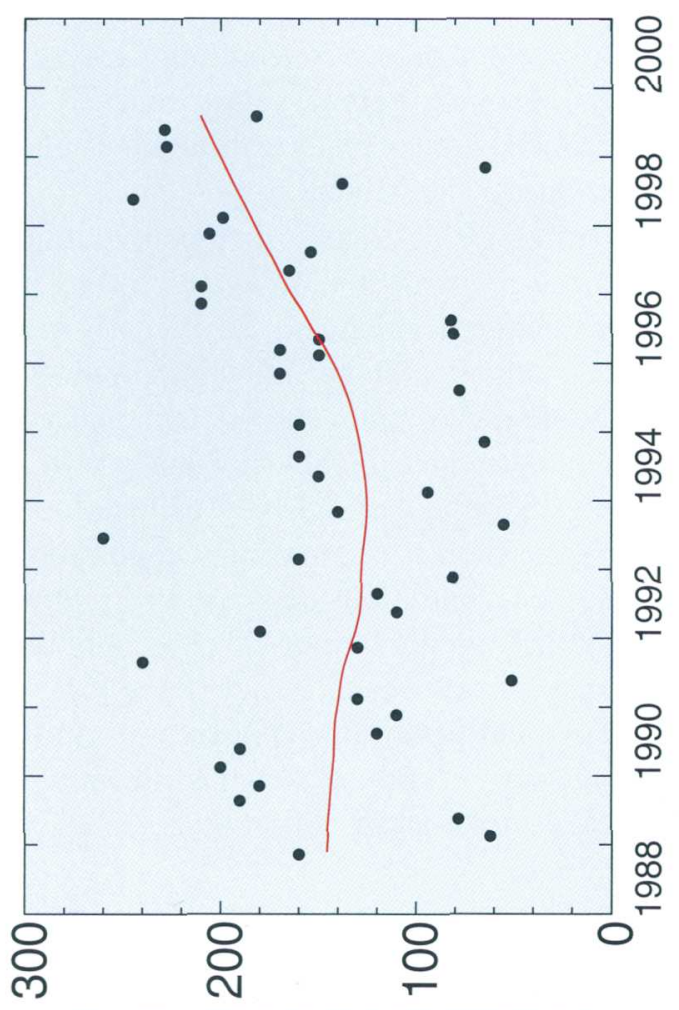

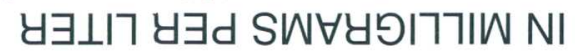
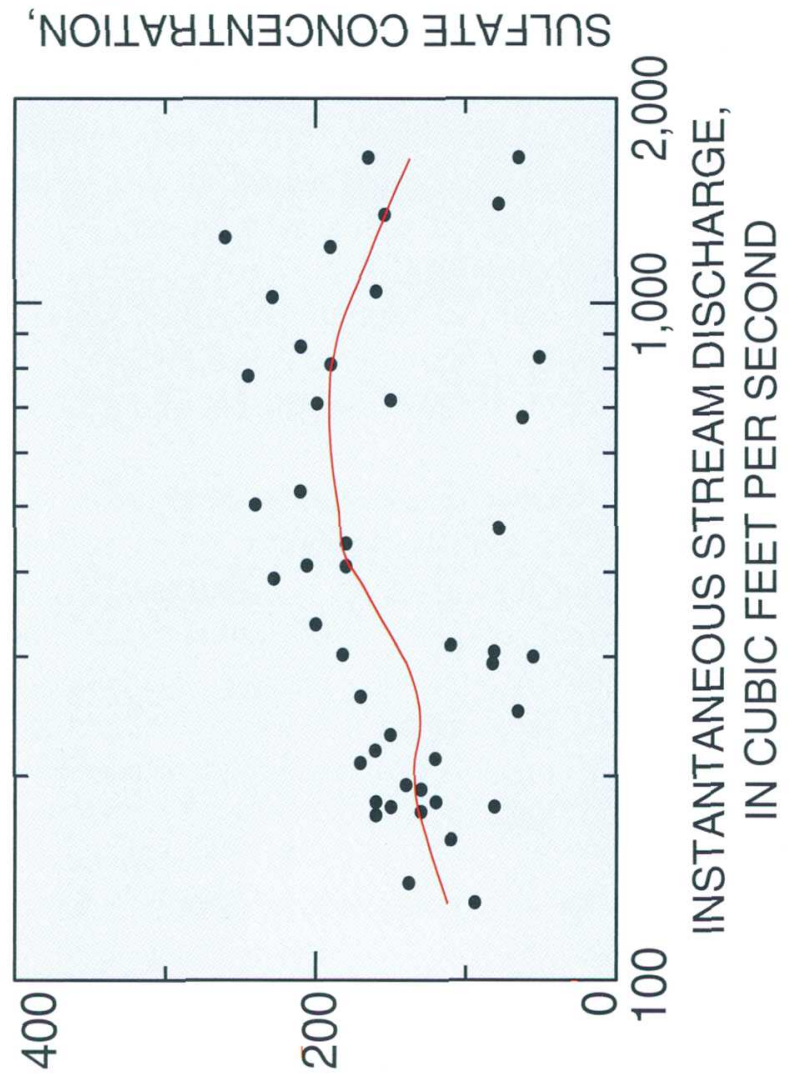

y

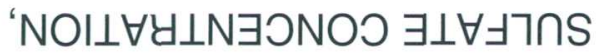

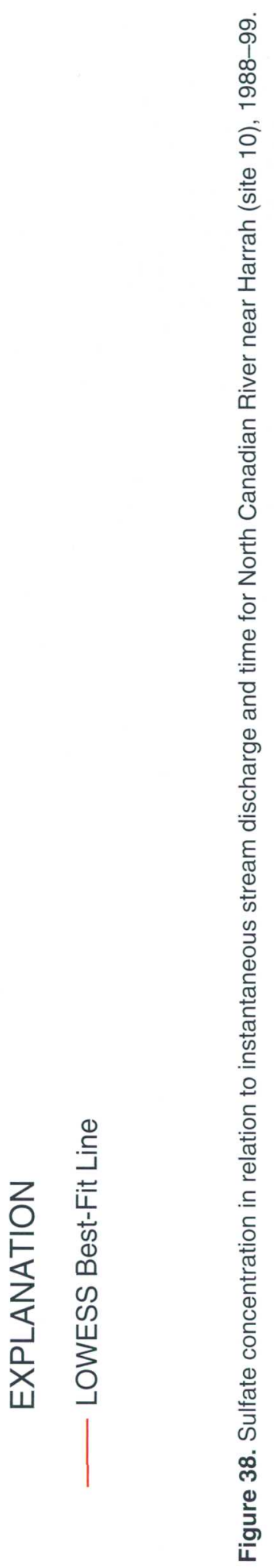




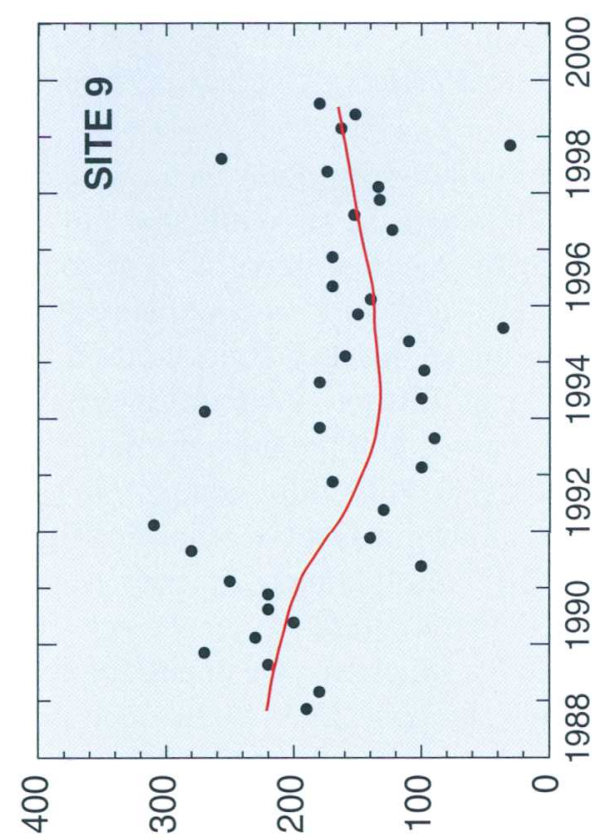

y

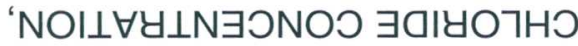

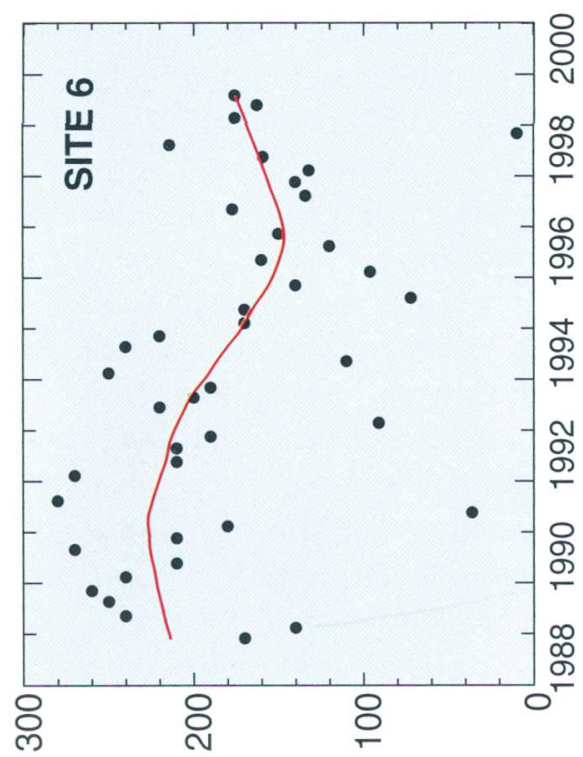

y $\exists \perp I 7$ y

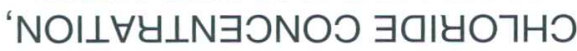

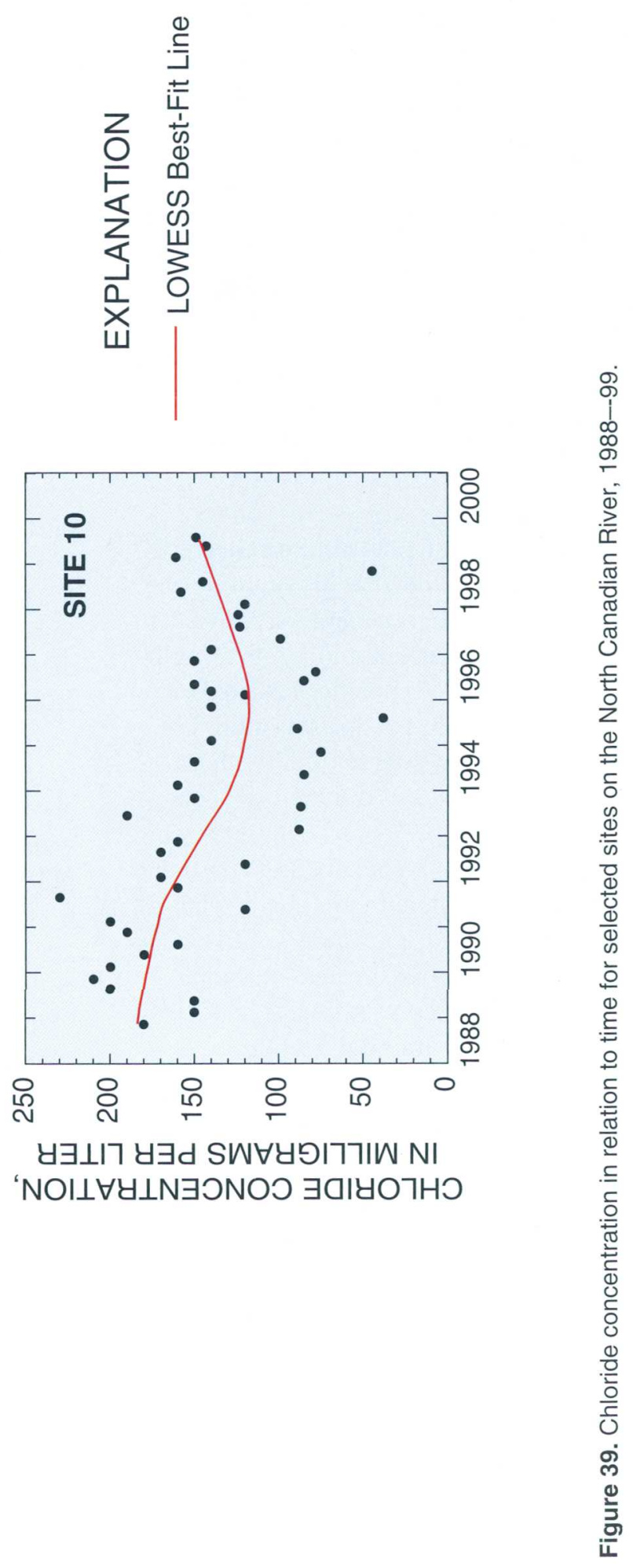


time of brines produced as by-products of petroleum production.

Fluoride concentrations decreased with increasing streamflow at sites 9 and 10 and increased with time at site 10 . The increase with time at site 10 was 0.015 milligram per liter per year or 2.1 percent per year of the median concentration during the reporting period.

Silica concentration increased with increasing streamflow at sites 6 and 10, perhaps due to runoff of clay minerals in soils during high flows. There was significant seasonality of silica concentration at site 10 , with maximum concentration in November. Silica may be taken up by diatoms and larger plants during the summer and may be released with die off of those plants in the fall and winter.

\section{Nutrients}

Log-transformed nitrite plus nitrate concentration increased with flow and decreased with time at site 6 at a rate of 0.0065 milligram per liter per year, or 5.9 percent of the median concentration of 0.11 milligram per liter for the period (Appendices 2 and 3). The upstream location of site 6 means that it is more likely to be dominated by nonpoint-source runoff, which may carry increased quantities of nitrate.

Nitrate concentration decreased with increasing streamflow at sites 9 and 10 (Appendix 3). Sites 9 and 10 are downstream from treated wastewater discharges (point sources) in Oklahoma City, which would tend to be diluted by high flows. Untransformed nitrite plus nitrate concentration decreased with time at site 10 at a rate of 0.0583 milligram per liter per year or 3.1 percent of the median concentration (1.9 milligrams per liter) for the period (Appendices 2 and 3). That decreasing concentration may be due to improvements in treatment of wastewater discharged to the river.

Seasonal trends were indicated at sites 6,8 , and 9 , where concentration was greatest during January, and at site 10 , where nitrate concentration was greatest during December, perhaps due to lesser nutrient uptake by algae and other aquatic plants during the winter.

Ammonia concentration decreased with time at site 9 at a rate of 0.0105 milligram per liter per year or 11.7 percent of the median concentration $(0.009$ milligram per liter) per year. Log-transformed ammonia concentration increased with streamflow at site 10. A seasonal trend was indicated at sites 9 and 10 , with maximum concentration occurring in December and January, perhaps due to reduced uptake by algae and other aquatic plants in winter.

A seasonal trend was indicated for organic nitrogen at site 8 , where concentration was greatest during June, which may be due to increased algal productivity in summer in Lake Overholser, located upstream of site 8 .

Log-transformed dissolved nitrogen concentration decreased with increasing streamflow at sites 9 and 10 , which may be due to dilution of point-source contributions from wastewater treatment plants. Untransformed dissolved nitrogen concentration decreased with time at sites $6(0.0845$ milligram per liter per year or 8.5 percent of the median concentration for the period), 9 (0.0429 milligram per liter per year or 2.9 percent of the median concentration for the period), and 10 (0.109 milligram per liter per year or 4 percent of the median concentration for the period) (Appendices 2 and 3), which may be due to improved treatment of wastewater discharged to the river. A seasonal trend was indicated only at site 10 where dissolved nitrogen concentration is greatest during November (Appendix 3).

Log-transformed dissolved phosphorus concentration decreased with greater streamflows at sites 8,9, and 10 (Appendix 3). Untransformed phosphorus concentration decreased with time at sites $8(0.0182$ milligram per liter or 10 percent of the median concentration for the period), 9 ( 0.0263 milligram per liter or 8.5 percent of the median concentration for the period), and 10 (0.0818 milligram per liter or 17 percent of the median concentration for the period) (Appendices 2 and 3). The untransformed concentration of phosphorus also significantly decreased with streamflow and time at site 9 . A seasonal trend was indicated for phosphorus concentration at site 8 , where concentrations were greatest during July. Trends of dissolved orthophosphate concentration were similar to those for dissolved phosphorus, except that logtransformed organophosphate concentration at site 6 increased with increasing streamflow, with a seasonal peak occurring in November.

\section{Trace Elements}

Log-transformed dissolved iron concentration increased with increasing streamflow at site 6 , perhaps 
due to runoff of iron-rich soils and reduction in dissolved oxygen content in stream water during high flows. Untransformed iron concentration decreased with time at a rate of 0.759 microgram per liter per year at site 6 and at a rate of 0.781 microgram per liter per year at site 8 (Appendix 3).

Log-transformed dissolved manganese concentration decreased with increasing streamflow at sites 6 , 8, and 9 (Appendix 3). Untransformed manganese concentration at site 9 decreased with time at a rate of 2.14 micrograms per liter per year or 15 percent of the median value for the period (14 micrograms per liter) per year (Appendices 2 and 3). A seasonal trend also was indicated at site 9 , where concentrations were greatest during January.

\section{Organic Carbon}

Log-transformed total organic carbon concentration increased with greater streamflows at site 10 . Log-transformed total organic carbon concentration was seasonal for sites 8,9 , and 10 , with the greatest concentrations occurring during June, perhaps due to algal blooms or runoff from early summer thunderstorms. Untransformed total organic carbon concentration also was seasonal at sites 8 and 10, with annual peak concentrations occurring in June (Appendix 2).

\section{Pesticides}

Log-transformed dieldrin concentration and untransformed dieldrin concentration decreased with time at site 10 (fig 40). The rate of decrease was 0.0001 microgram per liter per year, or about 5.0 percent of the median concentration per year for the period (Appendices 2 and 3). Dieldrin concentration did not vary significantly with flow or season. Most uses of dieldrin have been banned since 1975, so gradual decreases in concentration should be expected. Continued detection of dieldrin in the North Canadian River 25 years after that ban was placed is noteworthy.

Log-transformed lindane concentration decreased with streamflow and with time at site 9 ( 0.0002 microgram per liter per year, or 10 percent of the median concentration per year for the period). Untransformed lindane concentration decreased with increasing streamflow at sites 9 and 10 (fig. 41). The untransformed concentration of lindane decreased with time at sites 9 and 10 (0.0012 microgram per liter per year or 12 percent of the median value per year for the period (Appendices 2 and 3, fig. 41). The seasonal peak of lindane concentration occurred in October at site 10 .

\section{Fecal-Indicator Bacteria}

Log-transformed fecal coliform colony counts increased with increasing streamflow at sites 6,9 , and 10 (fig. 42). Seasonal trends were indicated at site 6 where log-transformed colony counts were greatest during August and at site 10 where counts were greatest during November.

\section{Longer-term trends at site $\mathbf{1 0}$}

This report primarily includes data collected from 1988-99. However, data are available for site 10 for numerous constituents, dating back to 1977 . A review of those data indicates that substantial changes in concentrations of some constituents occurred around 1988. Prior to 1988, concentrations and variability of some constituents were much greater than for the post-1988 period.

Most of these changes may be attributable to improvements in sewage treatment practices, including filtering for ammonia and solids and restricting discharges of industrial wastewater into the municipal system (Perry Soltani, Oklahoma City Wastewater Utilities Department, oral commun., 2001). Changes in brine-disposal practices related to petroleum production may also affect water-quality, particularly specific conductance and chloride concentration.

Constituents with significant longer-term waterquality trends at site 10 include: specific conductance, biochemical oxygen demand, carbon dioxide, and chloride. Specific conductance generally decreased from 1977 to 1999 (fig. 43). Coincident with improvements at the wastewater treatment plant in the late 1980s, biochemical oxygen demand, much of which may be derived from organic solids and algae, 


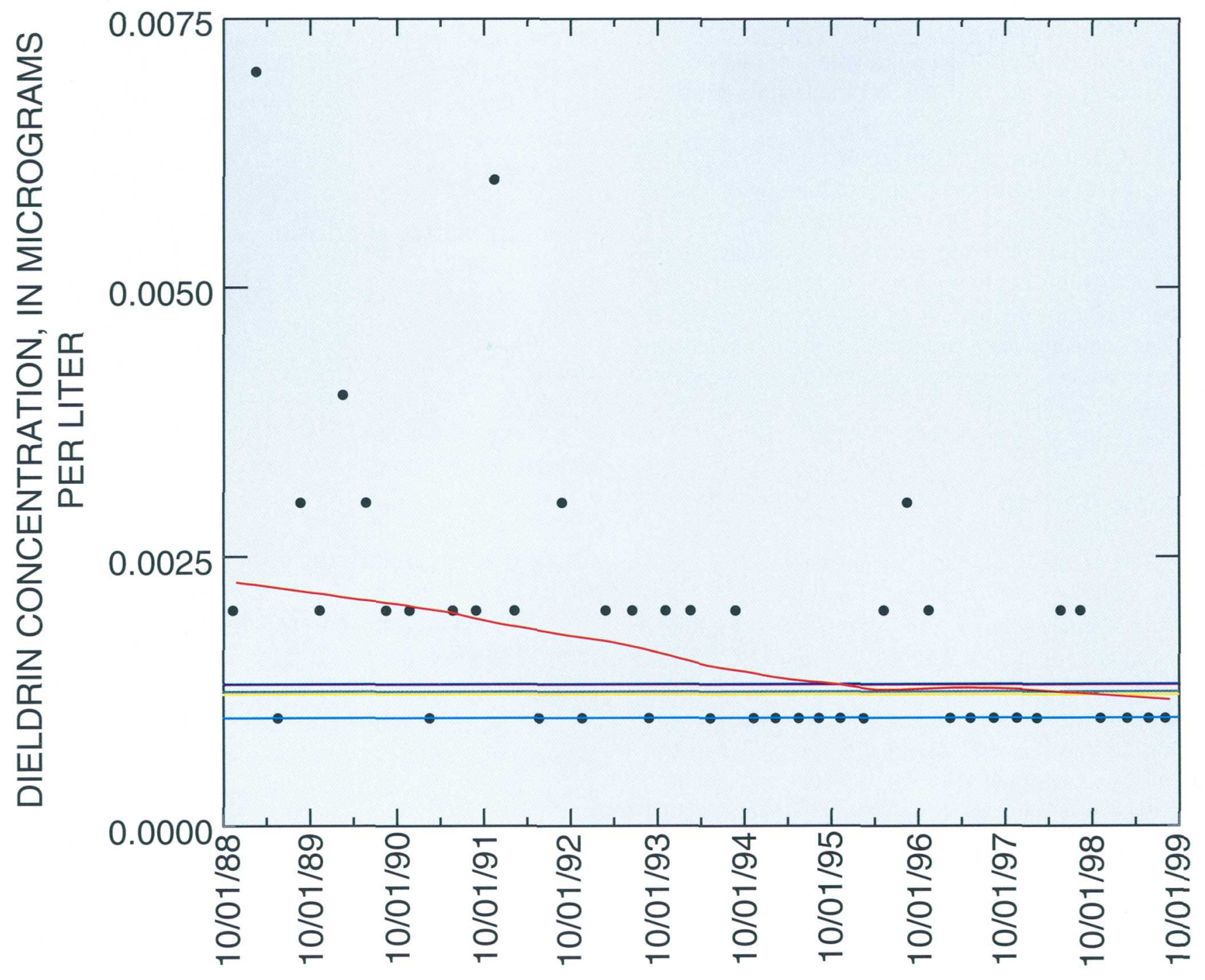

\section{EXPLANATION}

- LOWESS Best-Fit Line

— Method Reporting Limit Oklahoma Water-Column Criterion to Protect for Consumption of Fish and Water (0.001352 Microgram Per Liter)
- Oklahoma Numerical Chronic Criterion for Toxic Substances (0.0019 Microgram Per Liter)

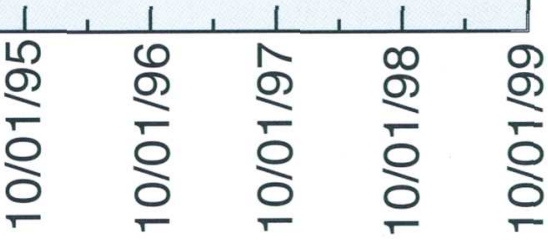

Figure 40. Dieldrin concentration in relation to time for North Canadian River near Harrah, Oklahoma (site 10), 1988-99. 


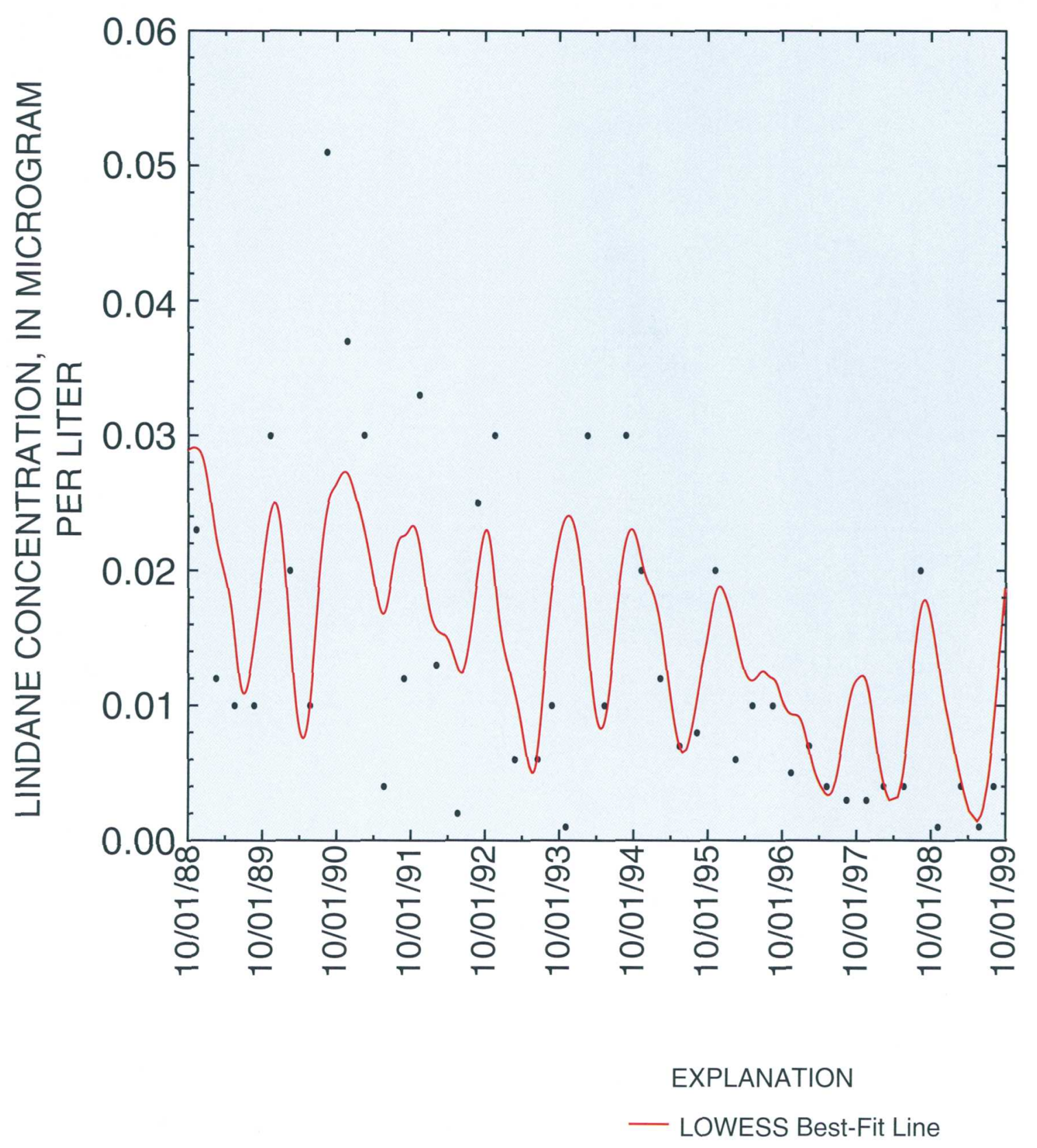

Figure 41. Lindane concentration in relation to time for North Canadian River near Harrah, Oklahoma (site 10), 1988-99. 

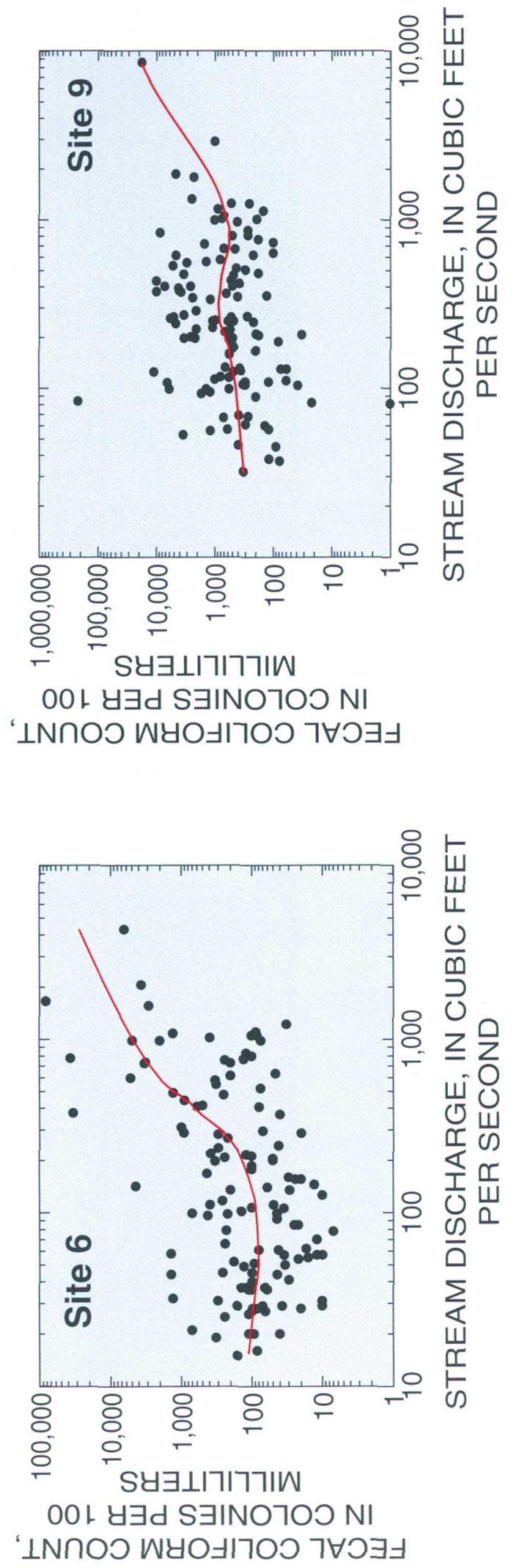

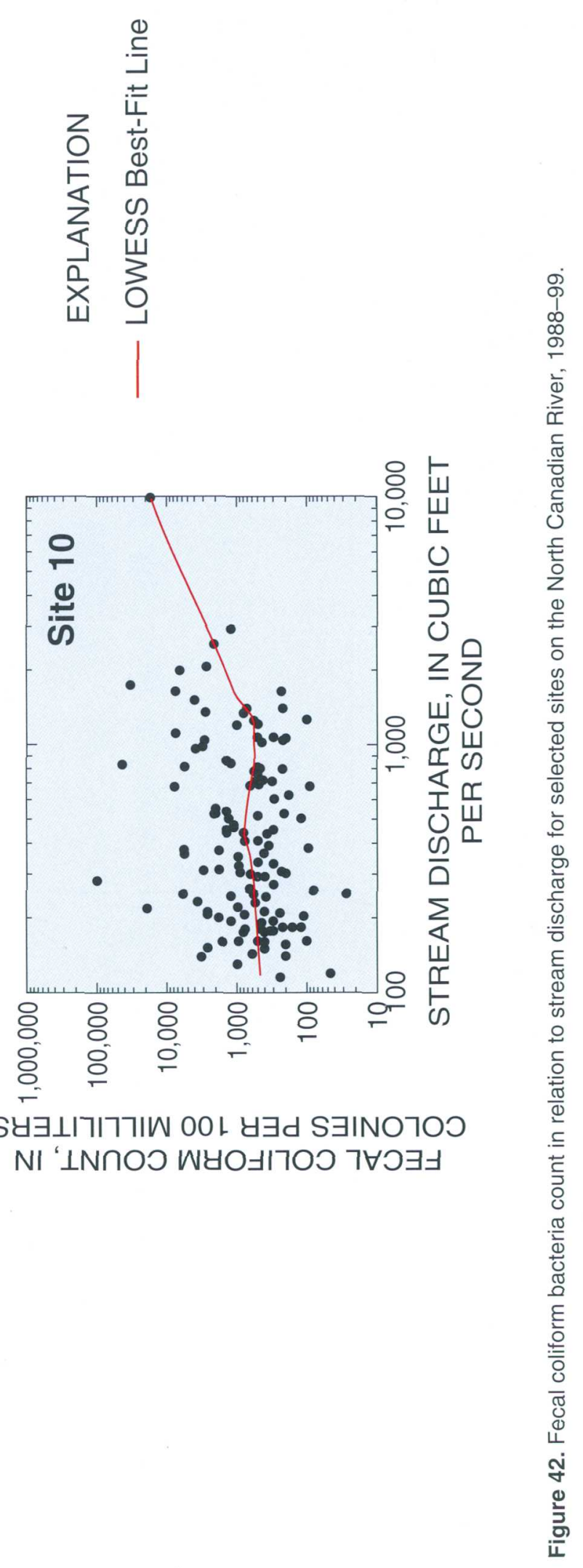




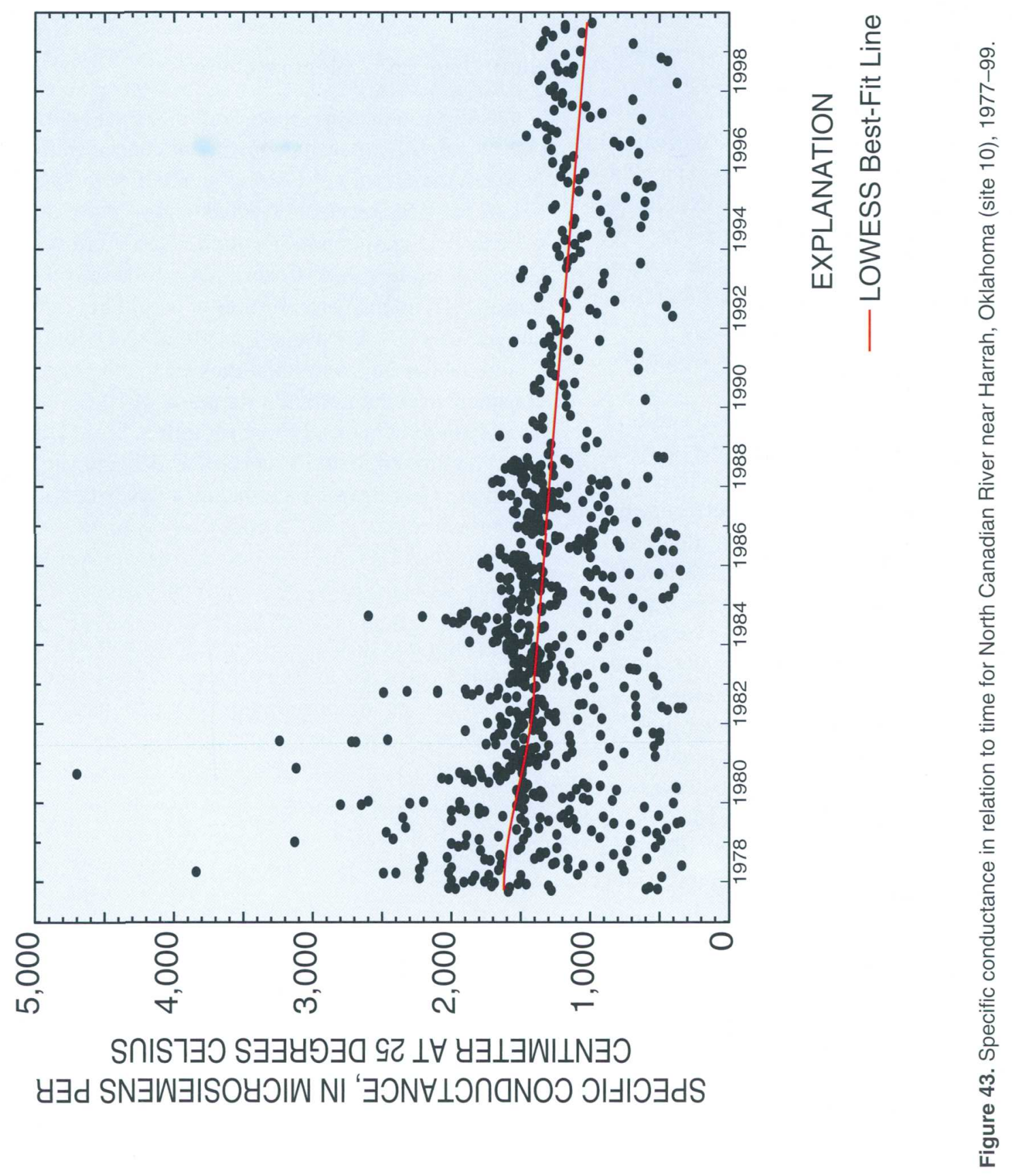


decreased (fig. 44). Biochemical oxygen demand has been increasing at the site since 1993, perhaps due to gradual increases in quantities of treated water discharged to the river, or to runoff from increased development on the river corridor upstream of the site. Carbon dioxide concentration, derived from oxidation of organic matter, decreased in a similar manner (fig. 45), but has not increased as biochemical oxygen demand has since 1993. Chloride concentration decreased since the late 1970s, with most subsequent concentrations being less than drinking-water standards and surface-water criteria (fig. 46).

Similar to the previous constituents, nutrient concentrations have decreased substantially since the late 1970s. Prior to 1986, ammonia-nitrogen concentration of greater than 5 milligrams per liter was common in the North Canadian River, as were exceedances of the Criterion Continuous Concentration for ammonia (fig. 47). Post-1986 data had very few exceedances of the Criterion Continuous Concentration.

The rapid reduction of ammonia concentration contrasts with lesser decreases in orthophosphate (fig. 48). Wastewater treatment practices that changed around 1987-88 appear to have been less effective at removal of phosphorus (fig. 48). However, there are other sources of phosphorus in addition to wastewater, including soils, livestock wastes and streambed sediments. Although there have been substantial decreases in concentrations of orthophosphorus (fig. 48), most samples from 1997-99 still had orthophosphorus concentrations greater than 0.1 milligram per liter.

Fecal coliform bacteria, which at high counts indicate fecal contamination of water, also decreased substantially over time at site 10 (fig. 49). Most samples, in recent years, exceeded the State of Oklahoma Primary Body Contact Recreation Standard for fecal coliform of 200 colonies per 100 milliliters monthly geometric mean (sampling frequencies were not sufficient to calculate monthly means). The Primary Body Contact Recreation Standard is intended to prevent enteric illnesses in swimmers and others participating in water recreation. Some samples continued to exceed the Oklahoma Raw Water Numerical Criterion for total coliform of 5,000 colonies per 100 milliliters (fig. 49), which is intended to protect consumers of public water supplies derived from surface water. Upstream land use is composed of mixed pasture, grasslands, commercial, industrial, and residential. There are multiple possible sources of bacteria, including: humans, dogs, horses, cattle, and wildlife.

\section{SAMPLING NETWORK EVALUATION}

\section{Areal Coverage}

\section{Bluff, Deer, and Chisholm Creeks}

Site comparisons indicated few statistically significant differences in constituent concentrations between these five sites. More than half of the pesticides analyzed were not detected, and of those that were detected (Appendix 1), none exceeded Maximum Contaminant Levels or Criterion Maximum Concentrations. Trend analyses, furthermore, did not indicate any increase or decrease in concentrations with time. Based on that information, it may be worthwhile to consider reducing pesticide sampling of Bluff, Deer, and Chisholm Creeks. Future sampling, for example, could be limited to site 3 on Bluff Creek and site 5 on Chisholm Creek, which are the most downstream sites on those creeks.

\section{North Canadian River}

Sampling at site 6 provides information about the quality of water in the North Canadian River upstream of the urbanized part of Oklahoma City and provides a baseline for evaluating effects on water quality from point and nonpoint sources from the urbanized area. Sampling at site 6 also facilitates evaluation of water quality in the North Canadian River with respect to its suitability as a water supply for the city. This function could be diminished if substantial land-use changes occur between site 6 and Yukon.

Restoring the monitoring site at County Road 4 at Yukon, upstream of the point where water is diverted to the city supply system may be worthwhile. Water quality monitoring at that site, known as North Canadian River near Yukon, Oklahoma (07239700), was conducted from 1952-53, 1974, and 1988-89 (Blazs and others, 2000). Sampling at this site could focus on constituents that have established Maximum Contaminant Levels or health advisories for drinking water. Sampling for total phosphorus and dissolved orthophosphate at this site may be useful because 


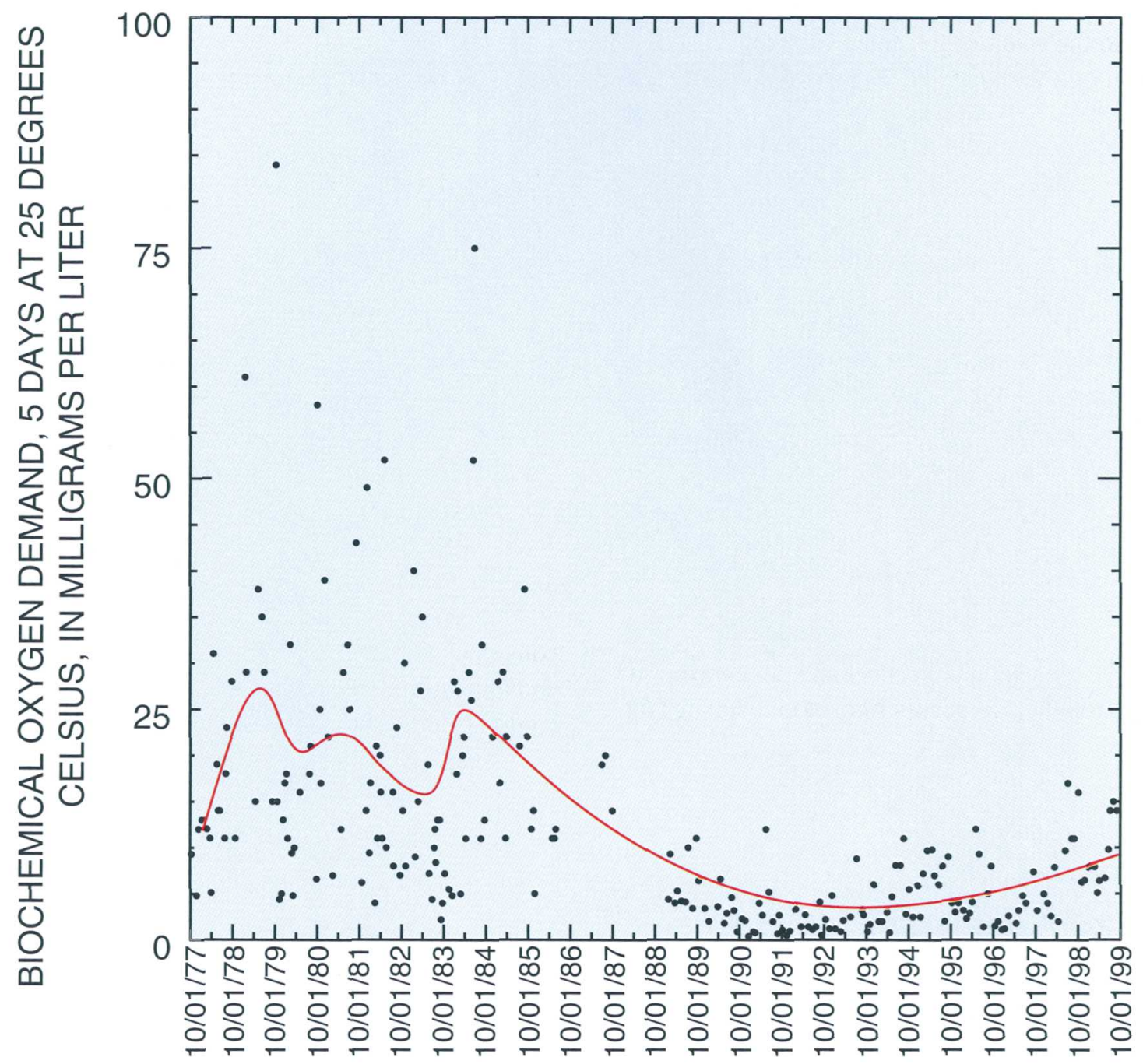

EXPLANATION

LOWESS Best-Fit Line

Figure 44. Biochemical oxygen demand in relation to time for North Canadian River near Harrah, Oklahoma (site 10), 1977--99. 


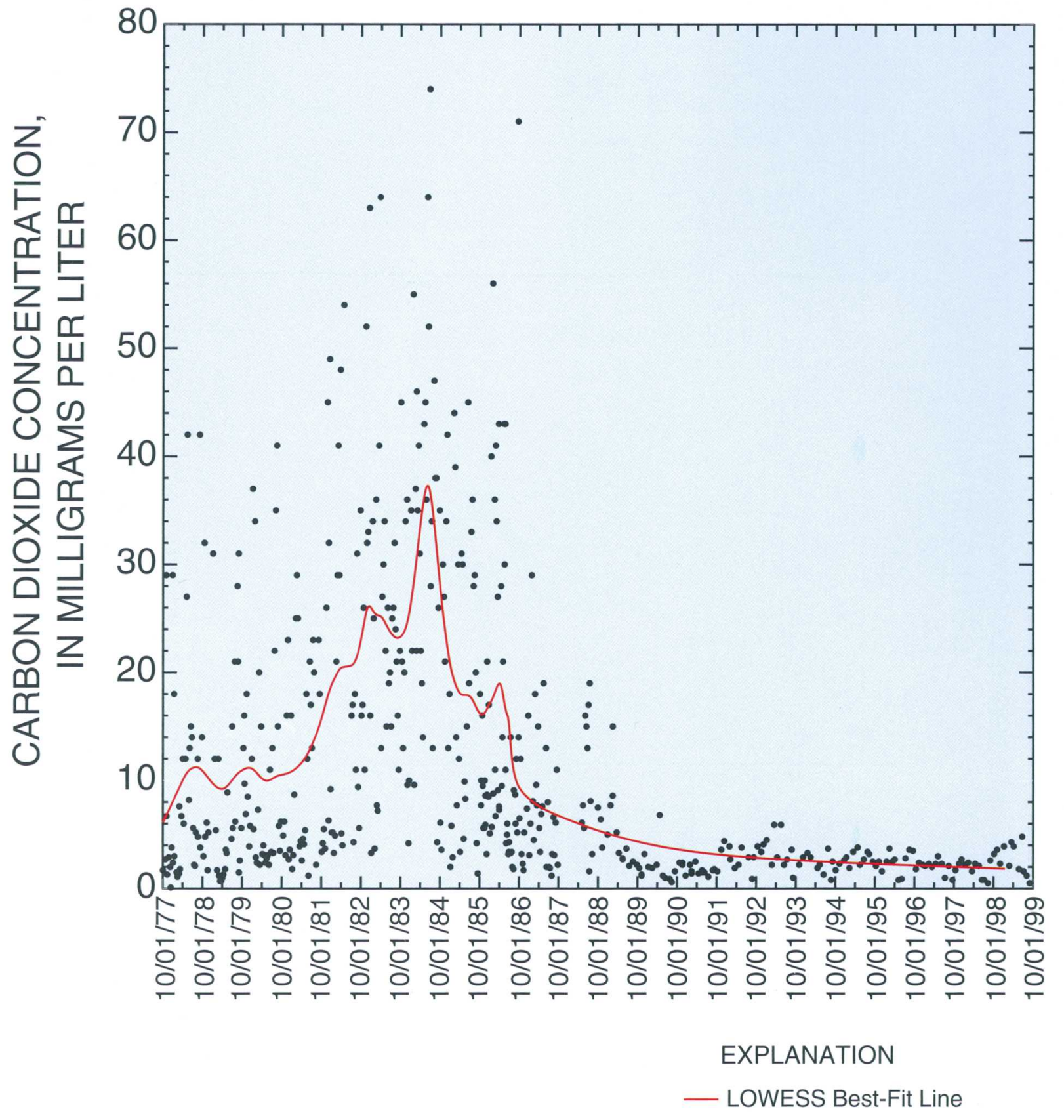

Figure 45. Carbon dioxide concentration in relation to time for North Canadian River near Harrah, Oklahoma (site 10), 1977-99. 


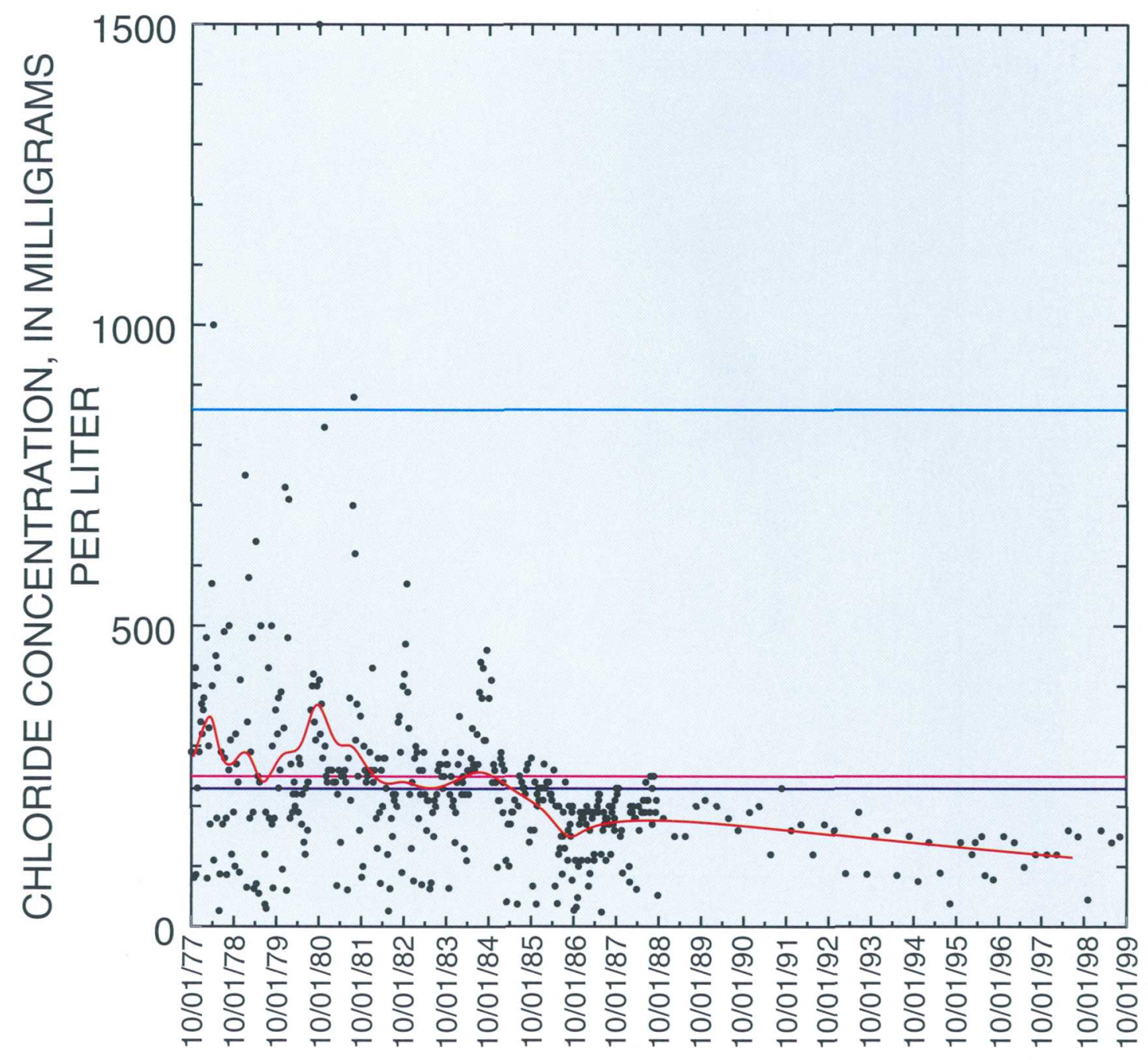

\section{EXPLANATION}

- LOWESS Best-Fit Line

- Criteria Maximum Concentration set by U.S. Environmental Protection Agency

- Secondary Maximum Contaminant Level Established by U.S. Environmental Protection Agency

- Criteria Chronic Concentration set by U.S. Environmental Protection Agency

Figure 46. Chloride concentration in relation to time for North Canadian River near Harrah, Oklahoma (site 10), 1977-99. 


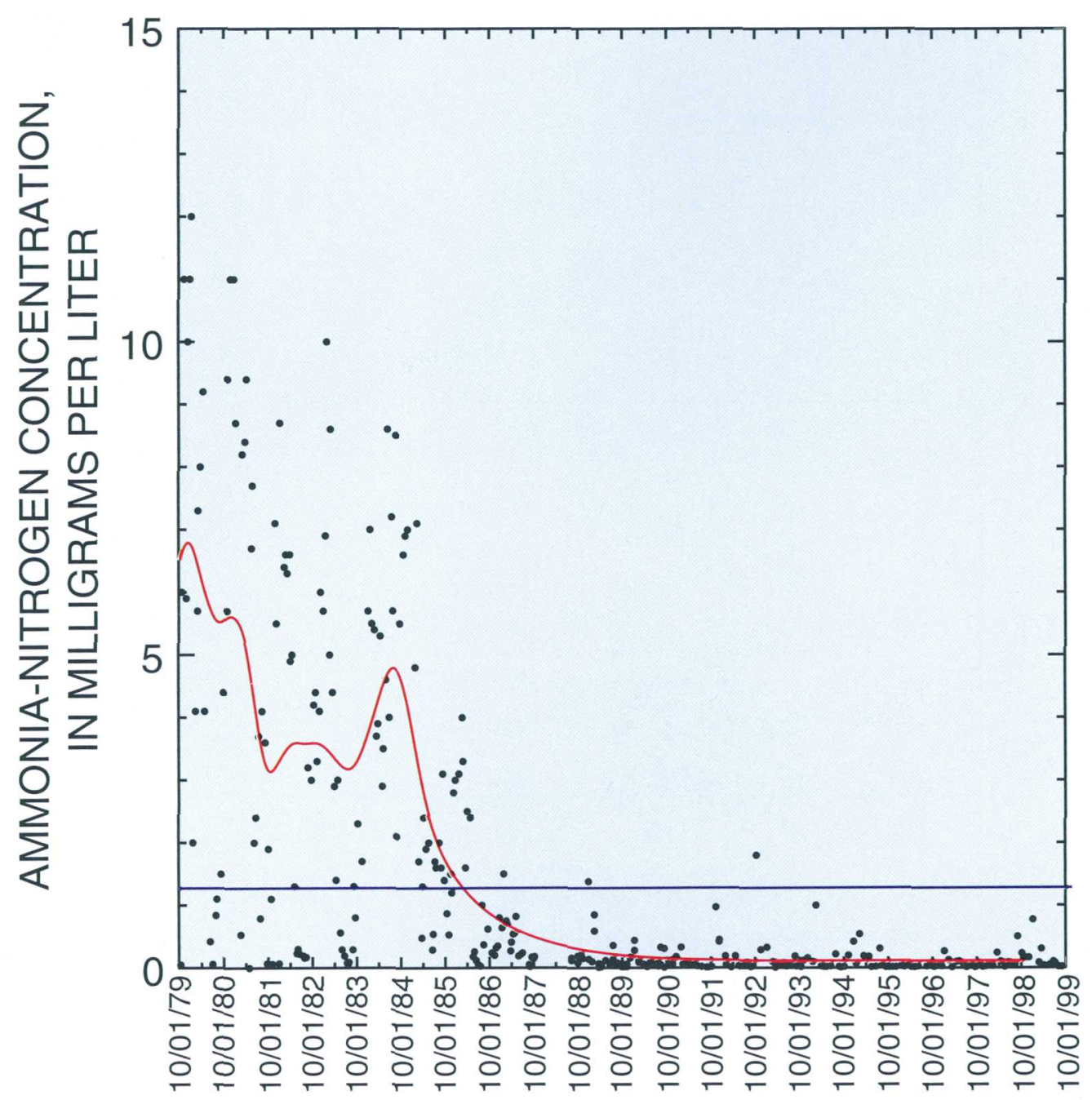

EXPLANATION

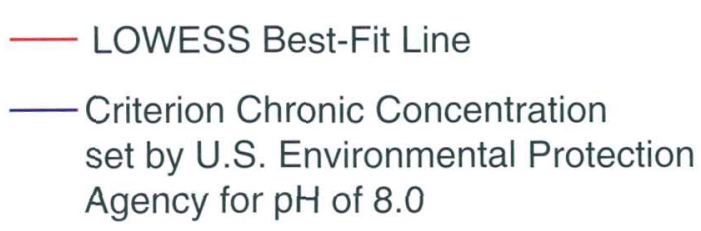

Figure 47. Ammonia-nitrogen concentration in relation to time for North Canadian River near Harrah, Oklahoma (site 10), 1979-99. 


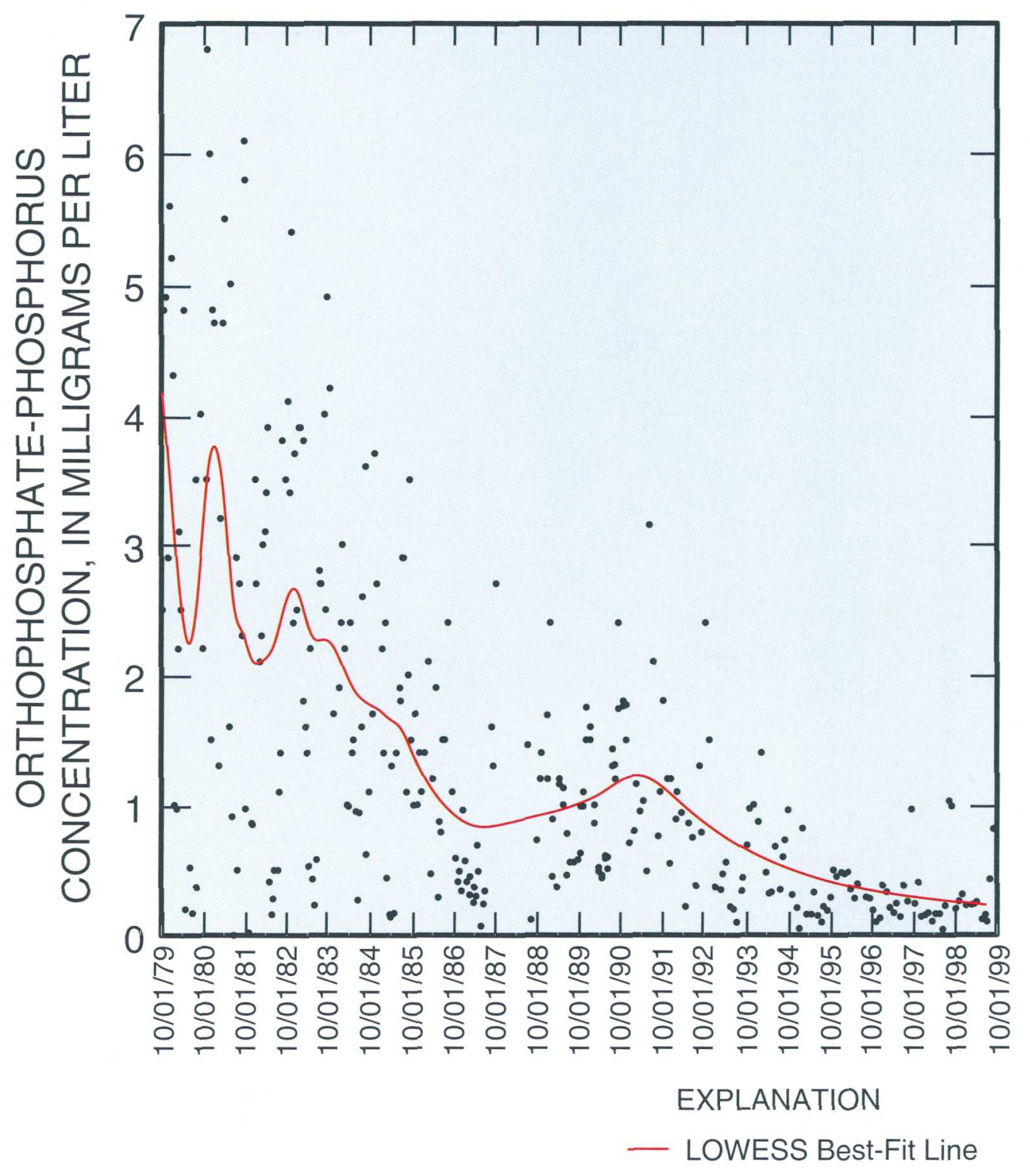

Figure 48. Orthophosphate-phosphorus concentration in relation to time for North Canadian River near Harrah, Oklahoma (site 10), 1979-99. 


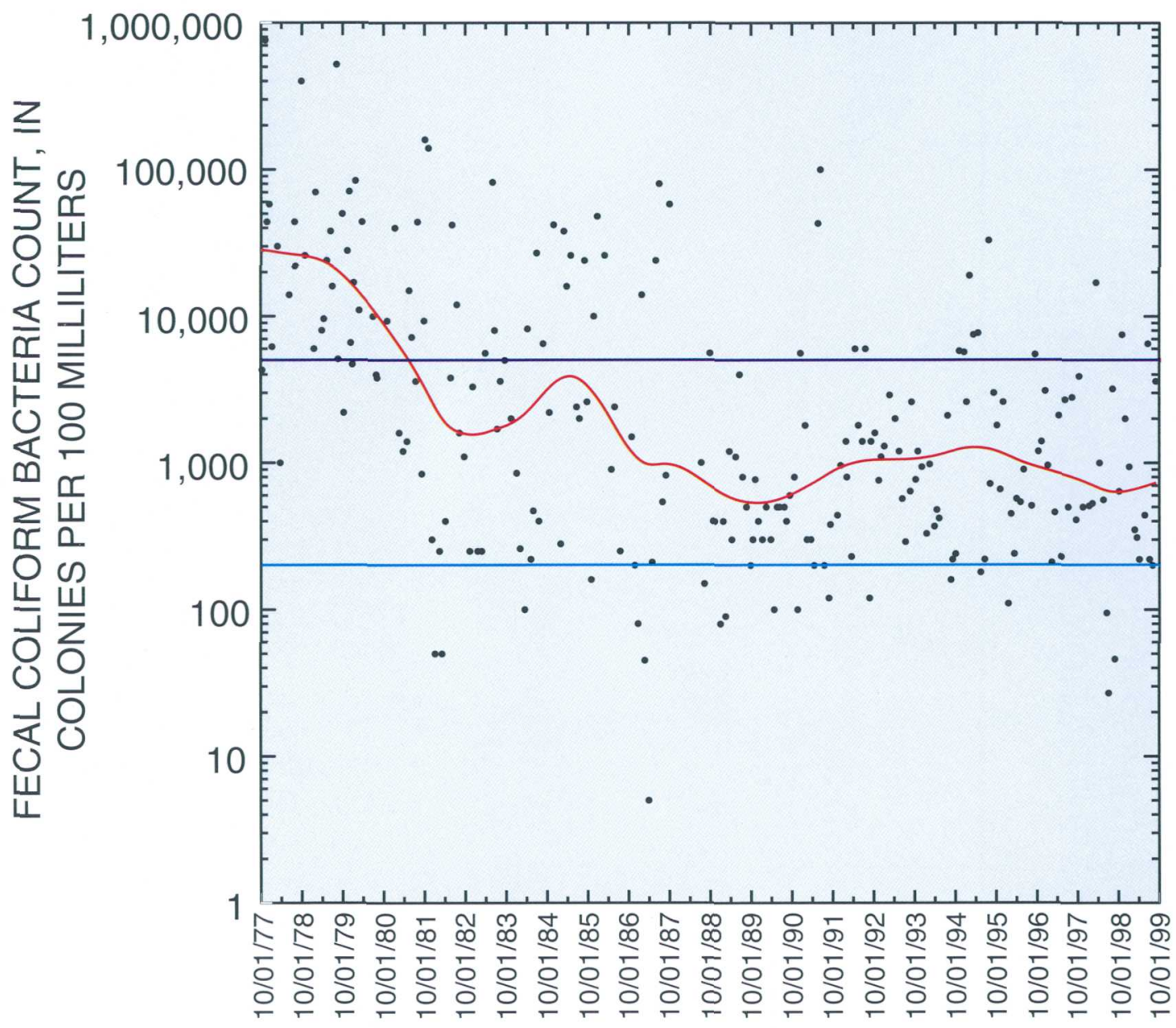

EXPLANATION

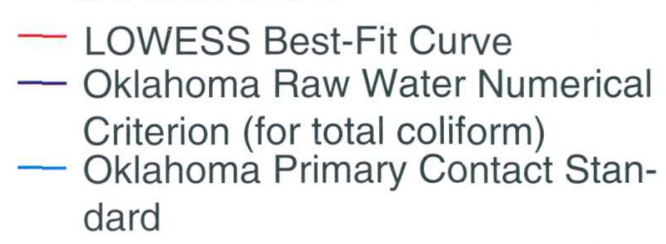

Figure 49. Fecal coliform bacteria count in relation to time for North Canadian River near Harrah, Oklahoma (site 10), 1977-99. 
water enriched in phosphorus can lead to excessive algal growth in Lake Overholser and Lake Hefner, which in turn can cause taste and odor problems for water supplies.

Sampling at site 8 provides information about changes in the quality of water in the North Canadian River after it has been stored in Lake Overholser. Site 8 also provides information about the quality of water upstream of most of the urban area. Continued sampling at site 8 , therefore, is likely to provide useful water quality information that can be compared with data collected downstream of wastewater discharges and other point and nonpoint sources from the intensively developed land that drains to the North Canadian River downstream of site 8. If the water quality discharged from Lake Overholser is of less concern than monitoring effects of wastewater discharge, then sampling at site 8 might be replaced by sampling farther downstream at a site just upstream of the wastewater outfall.

Discontinuing sampling at site 9 may be advantageous, but continuation of sampling at site 10 would be useful. Site comparisons indicate that there is no significant difference in concentrations of most constituents at site 9 relative to site 10. Sampling at site 9 provides information about water quality in the North Canadian River downstream of the Oklahoma City wastewater discharge outfall. As such, it facilitates evaluation of effects of the wastewater discharge on water quality through comparisons with data at site 8. Farther downstream, concentrations of nitrate, dissolved phosphorus, and dissolved orthophosphate at site 10 were significantly greater than concentrations at site 9 , indicating discharges of nutrients to the river between those sites (Appendix 2). Site 10 is well situated, being downstream of the heavily urbanized part of Oklahoma City. That site thus integrates the sources and processes that affect water quality in the North Canadian River as it flows through Oklahoma City.

Real-time or periodic monitoring of dissolved oxygen in the pools that form behind low-water dams being installed in 2002 would help anticipate and document if anoxic conditions develop and cause odor problems or fish mortality.

\section{Deep Fork Watershed}

Establishment of a sampling site on the Deep Fork, possibly near the point where the Deep Fork flows out of Oklahoma City, would be worthwhile. The urbanized part of Oklahoma City forms the headwaters of Deep Fork, a stream that flows northeasterly to Lake Arcadia. Substantial area, much of it urbanized, drains to the Deep Fork within Oklahoma City. A site near that location would be useful for evaluating the effects of discharges and stream processes on stream-water quality in Oklahoma City and possible effects on one of the primary drinking water sources for the City of Edmond, and exposure of recreational users of the reservoir to contaminants such as pesticides and bacteria.

\section{Sampling Frequency}

\section{Adequacy with respect to streamflow variability}

Water-quality constituents commonly are streamflow dependant. Samples should be collected across the full range of flows to evaluate a wide range of water-quality conditions. When monitoring data are used for load calculations, which may be needed in future total daily maximum load evaluations or other investigations, sampling across the range of flows, particularly high flows, is vital.

Streamflows at the time of sample collection were compared to the full range of daily streamflows that occurred from 1988-99 at sites 6, 8, 9, and 10. The 10th, 25th, 50th, 75th, and 90th percentiles for daily flows were similar to streamflows for the samples that were collected approximately monthly (fig. 4). Samples for major ions and trace elements, which were collected quarterly, covered a smaller range of flows; in particular, extreme low and high flows may be under-sampled for these constituents.

Minor modifications to the major ion and trace element sampling program could yield benefits for future analyses of the data. Quarterly sampling for major ions would be important for future trend analyses and could be supplemented with as many as six samples per year collected during high flows and two additional samples during low flows. Samples collected at high flows at different seasons would aid in calculation of annual constituent loads. Additional low-flow samples would aid evaluations of exceedances of water-quality criteria, especially for chloride, and sulfate, which periodically exceeded ambientwater-quality criteria and drinking-water standards in the past. 


\section{Adequacy with respect to trend analysis}

The sampling program for Bluff, Deer, and Chisholm Creeks is too new to reliably conduct meaningful trend analyses. Future trend analyses will benefit from the instantaneous flow measurements now conducted at the sites. Because no continuous gages exist, evaluation of flow coverage will need to be performed using nearby gaging stations. The current sampling frequency will be adequate to evaluate trends.

The sampling program for the North Canadian River is well suited to determining long-term trends. In general, greater frequency of data collection will yield more power in trend detection, but there are diminishing returns offered by each incremental increase in sampling frequency. Four to six samples per year are well suited for analyzing trends in constituents that do not exhibit large variability with flow or season (such as major ions) (Vecchia, 1993). Greater sampling frequency may be useful for constituents with greater variability in concentrations.

Trend analysis requires having samples collected at about the same times every year. For example, quarterly sampling should target the same months from year to year. If samples are added to a quarterly schedule, the new schedule should not be bimonthly, but rather preserve the old sampling schedule with the new samples added during previously unsampled months. Likewise, if a monthly sampling schedule is reduced to 8-10 samples per year, it should be done by discontinuing sampling during certain months.

Consideration also could be given to other objectives, such as evaluation of water quality for exceedances of standards, which may dictate collection of some samples during hydrologic extremes, and estimation of loads.

\section{Analytical Schedules and Water Properties}

\section{Dissolved oxygen}

Dissolved oxygen concentration and saturation of dissolved oxygen (fig. 3 ) indicate that both high and low extremes occur in the North Canadian River, and to a lesser extent, in Bluff, Deer, and Chisholm Creeks. Decrease of dissolved oxygen concentration can result from introduction of oxygen-demanding substances from a variety of sources such as wastewater effluent, storm water runoff, and industrial discharges. In nutrient-enriched streams, however, extreme diurnal fluctuations occur when algal photosynthesis brings about supersaturation of dissolved oxygen during daylight, followed by decrease of dissolved oxygen concentration during darkness, when photosynthesis stops but algal respiration continues. Water-quality sample collection typically is done during daylight hours, when photosynthesis is occurring, and, therefore, tends to under-represent periods when dissolved oxygen may be at minimums.

A complete review and analysis of the continuous record of dissolved oxygen concentration in the North Canadian River was beyond the scope of this report, but a review of recent data (1999) showed that the North Canadian River at site 10 underwent extreme fluctuations of diurnal dissolved oxygen concentration in August. Continued operation of the monitoring devices will provide a means to track the occurrence and severity of these short-term, but potentially harmful, depletions of dissolved oxygen. Additional investigation would be useful to determine whether algal productivity is the primary mechanism driving the observed oxygen dynamics in the North Canadian River. Continuous-record dissolved oxygen data, which can be used to determine rates of photosynthesis, would assist in making that determination.

\section{pH}

Continued collection of $\mathrm{pH}$ data is warranted, owing to the occasional exceedances of ammonia standards in the North Canadian River. $\mathrm{pH}$ data are needed for each sample to determine exceedances of the Criterion Continuous Concentration and Criterion Maximum Concentration.

\section{Streamflow}

Continued collection of continuous streamflow data at North Canadian River sampling sites will enable calculation of constituent loads. Information about load accruals within the reach will be useful for addressing total maximum daily load requirements. Accuracy of load estimates improves when continuous streamflow data are augmented by a sampling program that includes collection of an adequate number of samples during periods of increased streamflow, when constituent loads are greatest. Calculation of flow- 
weighted concentrations, by modeling concentration versus streamflow at sampling sites with stream gages would help to distinguish the effects of discharge trends on concentration trends, but that analysis was beyond the scope of this report.

\section{Major ions}

Chloride concentration frequently exceeded the Secondary Maximum Contaminant Level and Criterion Continuous Concentration in the North Canadian River. Sulfate and manganese concentrations also frequently exceeded Secondary Maximum Contaminant Levels in the river. Therefore, continued monitoring of major ions and manganese may be worthwhile to evaluate long-term trends in those constituents.

Given the high sulfate concentration in streams in Oklahoma City, and low dissolved oxygen concentrations, evaluating diurnal fluctuations of hydrogen sulfide concentration would be useful to determine if exceedances of Criterion Continuous Concentration for hydrogen sulfide occur.

\section{Nutrients}

Sampling for determination of nutrients from Bluff, Deer, and Chisholm Creeks would assist in evaluation of trophic status and determination of changes in nutrient loading that may arise as this watershed undergoes continued urbanization.

Addition of total phosphorus to the analytical schedule will provide information needed to determine total phosphorus loads. Most samples from the North Canadian River analyzed for nutrients included determinations of dissolved phosphorus and orthophosphate, but most were not analyzed for total phosphorus. Total phosphorus concentration was determined for 18 samples collected at site 10 . Those data indicate that a substantial amount of phosphorus is associated with particulate matter.

Ammonia occasionally exceeded Criterion Continuous Concentration values at North Canadian River sites from 1988-99. Although ammonia concentration was markedly greater in the previous decade (1979-88), the occasional exceedance of Criterion Continuous Concentration warrant continued collection of samples for analysis of ammonia.

\section{Suspended solids}

Sampling for suspended solids conducted in the North Canadian River can be enhanced by adding suspended sediment and volatile solids to the analytical schedule. Analysis of suspended sediment provides for a more complete measure of the total sediment discharge at a sampling site. Analysis of volatile solids provides information for determining whether a substantial portion of sediment discharge is comprised of algae and organic detritus.

\section{Trace elements}

The Maximum Contaminant Level for cadmium is 5 micrograms per liter, therefore, the current analytical procedure, having a method reporting limit of 8 micrograms per liter, is insufficient to determine whether the cadmium standard is exceeded.

The Oklahoma Water Column Criterion to Protect for the Consumption of Fish Flesh and Water for mercury ( 0.05 microgram per liter), is less than the current method reporting limit of 0.1 microgram per liter; thus, mercury concentration in water cannot be adequately compared to that standard. Exceedance of the Criterion Maximum Concentration (1.4 micrograms per liter) in one sample from site 10 should be viewed in light of historical problems with sample contamination, which cast doubt on historical mercury data. The main concern with low-level mercury contamination of aquatic systems is bioconcentration in the food chain, such that fish can contain mercury levels that are potentially toxic to wildlife and humans.

As such, further collection of water samples for mercury should be predicated on (1) occurrence of mercury-based fish-consumption advisories that prompt investigation of aquatic mercury cycling; or (2) acknowledgment that the current (post-1994) sampling and analytical scheme is sufficient only for detecting mercury concentration much greater than those in most natural waters. In addition, sampling for methylmercury, the most bioavailable form of mercury, may be worthwhile.

The current method reporting limit for lead in the program is 100 micrograms per liter; therefore, a more sensitive laboratory method for determination of lead should be used to evaluate compliance with water-quality standards for lead. The Oklahoma Raw Water Numerical Criterion for lead is 100 micrograms per liter. The Criterion Maximum Concentration for 
lead is 65 micrograms per liter and the Criterion Continuous Concentration is 2.5 micrograms per liter.

The current method reporting limit for silver is 4 micrograms per liter; therefore, a more sensitive laboratory method should be used to evaluate compliance with the Criterion Maximum Concentration for silver. The Criterion Maximum Concentration for silver is 3.4 micrograms per liter.

A short-term reconnaissance study of trace elements may be warranted for the following reasons:

1. The sampling program analyzes for dissolved metals, but many trace metals are highly sorptive, and would be associated largely with sediment in transport. A short-term study could compare dissolved and total metal concentrations. Total concentrations and continuous streamflow data also enable estimation of total loads of metals in stream transport. Dissolved (filtered water) samples are preferred for long-term monitoring, if drinking-water source assessment and bioavailability are primary concerns.

2. Use of ultra-clean field methods, and qualified laboratories, to analyze parts per trillion concentrations of several trace elements such as cadmium, lead, and mercury, would provide useful information on metal concentrations with respect to Federal and state standards. These elements may be present at concentrations that are greater than applicable standards, but the data are insufficient to determine that possibility.

3. For other elements, low-level detection methods, performed with current methods, would aid in interpretation of historical data, or possibly would reveal inadequacies in historical measurements of specific elements.

\section{Volatile Organic Compounds}

Advances in analytical technology have reduced method reporting limits for volatile organic compounds in water by as much as one-hundred-fold since 1990. A synoptic sampling for volatile organic compounds at all of the stations would be useful to determine the current occurrence and distribution of volatile organic compounds in surface water in the area. If volatile organic compound concentrations were determined to exceed water-quality standards, periodic sampling for those compounds might be useful and sampling of finished water also might be useful.

\section{Pesticides}

Reducing sampling for pesticides that were detected infrequently may be worthwhile. Pesticides that were not detected in any samples, and those present in concentrations substantially less than standards might be deleted from the sampling program, unless required by regulatory programs. However, reducing the list of pesticides analyzed to only those previously detected may not be practical or advisable because: (1) pesticides typically are analyzed in groups of similar compounds by analytical schedules, and (2) only analyzing for previously-detected pesticides would ignore the possibility of new pesticides being detected with time.

Pesticide information is enhanced when samples are collected over a wide range of streamflows, with emphasis on collecting samples during runoff periods when streamflow is increasing.

When sampling source water for municipal supply systems, analyzing for dissolved pesticides may be advantageous because pesticides in dissolved form are less likely to be removed by water treatment processes. Most samples have been analyzed for total (unfiltered water) pesticide concentrations. Analyses for these pesticides in treated water, using similar analytical methods, also may be useful to monitor trends in pesticide concentrations and to evaluate the effectiveness of treatment systems in removing those contaminants.

\section{Fecal indicator bacteria}

Considering the high counts of fecal coliform and fecal streptococci measured in recent years at sites on the North Canadian River, continuing those measurements is probably worthwhile for monitoring trends, or perhaps only continuing to analyze counts of fecal coliform, rather than fecal streptococci bacteria; however, adding better indicators of public health concern such as Esherichia coli (E. coli) and enterococci also might be considered. Substantial data exist for counts of fecal coliform and fecal streptococcus, two classes of bacteria that have long been used as indicators of fecal contamination. E. coli and enterococci are recognized as better predictors of swimmingassociated gastroenteritis (Cabelli, 1977, p. 222-238; Dufour and Cabelli, 1984), and are used as indicator organisms in many water-quality monitoring programs. 


\section{Chlorophyll}

Sampling for analysis of phytoplankton chlorophyll- $a$ is likely to provide a reliable measure of algal productivity in larger streams. Sampling for determination of chlorophyll- $a$, combined with sampling for nutrients (particularly total phosphorus) would facilitate determination of the extent to which algal productivity is responsive to nutrient concentrations.

Measures of algal productivity also may prove useful for understanding the relation between algal productivity and the dissolved-oxygen dynamics of these streams. Sampling for determination of chlorophyll- $a$ could be directed initially to both warm and cool seasons and a wide range of streamflows to gain an understanding of algal responses to varying stream conditions. Longer-term sampling could be directed to determination of average seasonal productivity values for the purpose of detecting changes with time.

\section{SUMMARY}

Water-quality data collected during 1988-99 at nine sampling sites on Bluff, Deer, and Chisholm Creeks, and the North Canadian River were summarized. Comparisons were made among sites for selected constituents that had 20 or more analyses per site. Comparisons were made using box plots and analysis of variance (ANOVA) followed by a TukeyKramer comparison based on data ranks. The box plots give a visual indication of the differences among sites, and the Tukey-Kramer groupings indicate if the differences are statistically significant. Statistically significant differences among sites were indicated for physical properties, total dissolved solids, major ions, trace elements, nutrients, turbidity, pesticides, and bacteria.

Concentrations of dissolved solids and sulfate generally decreased as streams flowed through the Oklahoma City urban area. Concentrations of organic carbon, nitrogen and phosphorus compounds, lindane, and 2,4-D, and frequencies of detection of pesticides increased in the North Canadian River as it flowed through the urban area. Volatile organic compounds were not detected in samples collected quarterly from 1988-90 at sites on the North Canadian River. Concentrations of some compounds, including dissolved oxygen, sulfate, chloride, ammonia, manganese, diazinon, dieldrin, and fecal coliform bacteria periodically exceeded Federal or state water-quality standards at some sites.

There was relatively little change in land use from the late 1970 s to the mid-1990s due to relatively modest rates of population growth in the study area during that period. Most changes in water quality in these streams and rivers may be due to changes in chemical use and wastewater treatment practices.

Results presented can be used to evaluate effects of wastewater treatment on surface-water quality and for designing changes to surface-water quality monitoring.

Regression analyses were used to identify constituent trends in the North Canadian River with respect to streamflow, season, and time. Based upon those analyses, trends for some constituents were indicated at all sites, but trends for most constituents were site-specific. Seasonal trends were indicated for several constituents, among them suspended solids, organic nitrogen, and biochemical oxygen demand which were greatest during summer; and dissolved oxygen, ammonia, and nitrite plus nitrate nitrogen, which were greatest during winter. Concentrations of dissolved oxygen, biochemical oxygen demand, fluoride, sulfate, iron, and manganese increased with time at some sites. Concentrations of chloride, nitrite plus nitrate nitrogen, dissolved phosphorus, dissolved orthophosphate, dieldrin, and lindane decreased with time at some sites. Many constituents which may be related to wastewater discharges decreased in concentrations in the North Canadian River since the late 1970s.

The sampling network was evaluated with respect to areal coverage, sampling frequency, and analytical schedules. Areal coverage could be expanded to include one additional watershed that is not part of the current network. A new sampling site on the North Canadian River might be useful because of expanding urbanization west of the city, but sampling at some other sites could be discontinued or reduced based on comparisons of data between the sites. Additional real-time or periodic monitoring for dissolved oxygen may be useful to prevent anoxic conditions in pools behind new low-water dams. The range of streamflows was adequately sampled when samples were collected monthly, but quarterly sampling schedules under-sampled streamflow extremes. The sampling schedules, both monthly and quarterly, are adequate to evaluate trends, but additional sampling during flow extremes may be needed 
to quantify loads and evaluate water-quality during flow extremes. Emerging water-quality issues may require sampling for determination of volatile organic compounds, sulfide, total phosphorus, chlorophyll-a, Esherichia coli, and enterococci, as well as use of more sensitive laboratory analytical methods for determination of cadmium, mercury, lead, and silver.

\section{REFERENCES CITED}

Agency for Toxic Substances and Disease Registry, 2001a, Chlordane: accessed January 15, 2001, at URL: http://www.atsdr.cdc.gov/tfacts31.html , 2001b Chlorpyrifos: accessed January 15, 2001, at URL: http://www.atsdr.cdc.gov/tfacts84.html , 2001c, Diazinon: accessed January 15, 2001, at URL: http://www.atsdr.cdc.gov/tfacts88.html , 2001d, Aldrin/Dieldrin: accessed January 15, 2001, at URL: http://www.atsdr.cdc.gov/tfacts 1.html , 2001e, Heptachlor: accessed January 15, 2001, at URL: http://www.atsdr.cdc.gov/tfacts 12.html

Anderson, R.M., Beer, K.M., Buckwalter, T.F., Clark, M.E., McAuley, S.D., Sams, J.I., and Williams, D.R., 2000, Water quality in the Allegheny and Monongahela River Basins, Pennsylvania, West Virginia, New York, and Maryland, 1996-98: U.S. Geological Survey Circular 1202, 32 p.

Antweiler, R.C., Goolsby, D.A., and Taylor, H.E., 1995, Nutrients in the Mississippi River, in Meade, R.H., ed. Contaminants in the Mississippi River: U.S. Geological Survey Circular 1133, p. 73-86.

Babiarz, C.L. and Andren, A.W., 1995, Total concentrations of mercury in Wisconsin (USA) lakes and rivers: Water, Air, and Soil Pollution, v. 83, p. 173-183.

Battaglin, W.A., and Goolsby, D.A., 1994, Spatial data in GIS format on agricultural chemical use, land use, and cropping practices in the United States: U.S. Geological Survey Water-Resources Investigation Report 944176, 87 p.

Blazs, R.L., Walters, D.M., Coffey, T.E., Boyle, D.L., and Wellman, J.J., 2000, Water Resources Data Oklahoma, Water Year 1999, vol. 1. Arkansas River Basin: U.S. Geological Survey Water-Data Report OK-00-1, 382 p.

Brigham, M.E., and Payne, G.A., 1999, Stream waterquality characteristics and trends, James River basin, North Dakota: U.S. Geological Survey WaterResources Investigation Report 99-4187, 129 p.

Cabelli, V.J., 1977, Indicators of recreational water quality, in Hoadley, A.W. and Dutka, B.J., eds., Bacterial indicators / health hazards associated with water, 1977: American Society for Testing and Materials, ASTM STP 635, p. 222-238.
Carlson, R.E., 1977, A trophic state index for lakes: Limnology and Oceanography, v. 22, p. 361-369.

Chatfield, C., 1980, The analysis of time series--an introduction (Second edition): London, Chapman and Hall, $268 \mathrm{p}$.

Cleveland, W.S., and McGill, R., 1984, Graphical perception: theory, experimentation, and application to the development of graphical methods: Annals of Mathematical Statistics, v. 21, p. 557-569.

Cleveland, W.S., 1985, The elements of graphing data: Monterey, Calif., Wadsworth Books, 323 p.

Conover, W.J, and Iman, R.L., 1981, Rank transformation as a bridge between parametric and nonparametric statistics: The American Statistician, v. 35, no. 3, p. 124-129.

Cornell University, 2001, Carbophenothion: accessed on January 15, 2001, at URL: http://pmep.cce.cornell.edu/profiles/insect-mite/ cadusafos-cyromazine/carbophenothion/insect-profcarbophe.html

Dufour, A.P. and Cabelli, V.J., 1984, Health effects criteria for fresh recreational waters: Cincinnati, Ohio, U.S. Environmental Protection Agency, EPA 600/1-84-004, $33 \mathrm{p}$.

Ferree, D.M., Christenson, S., Rea, A.H., and Mesander, B.A., 1992, Ground-water-quality assessment of the Central Oklahoma Aquifer, Oklahoma: hydrologic, water-quality, and quality-assurance data 1987-90: U.S. Geological Survey Open-File Report 92-641, 193 p.

Fuhrer, G.J., Gilliom, R.J., Hamilton, P.A., Morace, J.L., Nowell, L.H., Rinella, J.F., Stoner, J.D., and Wentz, D.A., 1999, The quality of our nation's water: nutrients and pesticides: U.S. Geological Survey Circular 1225, $82 \mathrm{p}$.

Ham, W.E., 1962, Economic geology and petrology of gypsum and anhydrite in Blaine County in Geology and mineral resources of Blaine County: Oklahoma Geological Survey, Bulletin 89, p. 100-148.

Helsel, D.R. and Hirsch, R.M., 1992, Statistical methods in water resources, Studies in Environmental Science 49: Elsevier, $522 \mathrm{p}$.

Hirsch, R.M., 2000, Priority issues for the Cooperative Water Program, Fiscal Year 2001: U.S. Geological Survey Water Resources Division Informational Memorandum no. 2000.13, 3 p.

Horowitz, A.J., Demas, C.R., Fitzgerald, K.K., Miller, T.L., and Rickert, D.A., 1994, U.S. Geological Survey protocol for the collection and processing of surfacewater samples for the subsequent determination of inorganic constituents in water: U.S. Geological Survey Open-File Report 94-539, 57 p. 
Information Ventures, Inc., 2001a, 2,4-DP: accessed on January 15, 2001, at URL: http://www.infoventures. com/e-hlth/pestcide/24dp.html

_2001b, Simazine: accessed on January 15, 2001, at URL: http://www.infoventures.com/e-hlth/ pestcide/simazine.html

Kendall, M.G., 1975, Rank correlation methods, Fourth edition: London, Charles Griffin, 202 p.

Oklahoma Water Resources Board, 2000, Oklahoma Water Resources Board Rules, Chapter 45. Oklahoma's Water Quality Standards, with amendments effective July 1, 2000, 87 p.

_ , 2002, Oklahoma Water Resources Board Rules, Chapter 46 Implementation of Oklahoma's Water Quality Standards, with amendments effective August 13,2001, $46 \mathrm{p}$.

Oregon State University, 2001, Lindane, accessed on January 15, 2001, at URL:

http://ace.orst.edu/info/extoxnet/pips/lindane.htm

SAS Institute, 1988, SAS procedures guide; Version 6, Fourth edition: Cary, N.C., SAS Institute, 441p. 1989a, SAS/STAT users guide, Version 6, Fourth edition, volume 1:Cary, N.C., SAS Institute, 943 p. 1989b, SAS/STAT users guide, Version 6, Fourth edition, volume 2: Cary, N.C., SAS Institute, 846 p.

Shiller, A.M. and Boyle, Edward, 1985, Dissolved zinc in rivers: Nature. v. 317, p. 49-52.

Stark, J.R., Hanson, P.E., Goldstein, R.M., Fallon, J.D., Fong, A.L., Lee, K.E., Kroening, S.E., and Andrews, W.J., 2000, Water quality in the Upper Mississippi River Basin, Minnesota, Wisconsin, South Dakota, Iowa, and North Dakota, 1995-98: U.S. Geological Survey Circular 1211, 35 p.

Tortorelli, R.L., 2000, Estimated total freshwater withdrawals for top ten counties in Oklahoma, 1995, by county, and source: accessed July 26, 2001, at URL: http://ok.water.usgs.gov/public/wateruse/top10co.total. 95.html

U.S. Census Bureau, 2001, Population estimates: accessed February 26, 2001 at URL: http://www.census.gov/population/www/coop/ estimates.html.

U.S. Environmental Protection Agency, 1976, Quality criteria for water: Washington, D.C., U.S. Environ- mental Protection Agency, Office of Water Planning and Standards, EPA 440/9-76/023, 537 p.

, 1994, 1:250,000 scale quadrangles of land use/land cover GIRAS spatial data in the conterminous United States: U.S. Environmental Protection Agency, Office of Information Resource Management.

, 1995, Drinking water and health advisories: U.S. Environmental Protection Agency, Office of Water, $11 \mathrm{p}$.

_- 1999, National Recommended Water Quality Criteria--Correction. U.S. Environmental Protection Agency Office of Water, EPA 822-Z-99-001.

2000, EPA announces elimination of all indoor uses of widely-used pesticide diazinon; begins phase-out of lawn and garden uses: U.S. Environmental Protection Agency, Headquarters Press Release, December 5, 2000, 2 p.

U.S. Forest Service, 2001, Prometon: accessed on January 15, 2001, at URL: http://www.fs.fed.us/foresthealth/pesticide/ prometon.html

U.S. Geological Survey, 1999, Oklahoma land cover data set, National Land Cover Data Set (NLCD), accessed on January 15, 2001, at URL:

http://www.epa.gov/mrlc/nlcd.html.

_- 2001a, Chlorpyrifos, estimated annual agricultural use: accessed January 15, 2001, at URL:

http://water.wr.usgs.gov/pnsp/use92/chlrpyrfs.html

_ $2001 \mathrm{~b}$, Diazinon, estimated annual agricultural use: accessed January 15, 2001, at URL: http://water.usgs.gov/pnsp/use92/diaznon.html

_-, 2001c, Malathion, estimated annual agricultural use: accessed January 15, 2001, at URL: http://water.usgs.gov/pnsp/use92/malthion.html

Vecchia, A.V., 1993, Some recent advances in statistical analysis of spatial random processes, in Kelmelis, J.A., Snow, K.M, eds., Proceedings of the U.S. Geological Survey global change research forum, March 18-20, 1991, Herndon, Virginia: U.S. Geological Survey Circular 1086, p. 115

Windom, H.L., Byrd, J.T., Smith, R.G., Jr., Huan, Feng, 1991, Inadequacy of NASQAN data for assessing metal trends in the nation's rivers: Environmental Science and Technology, v. 25, p. 1137-1142. 
APPENDIX 


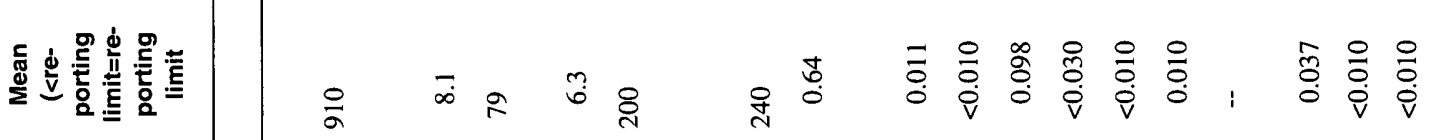

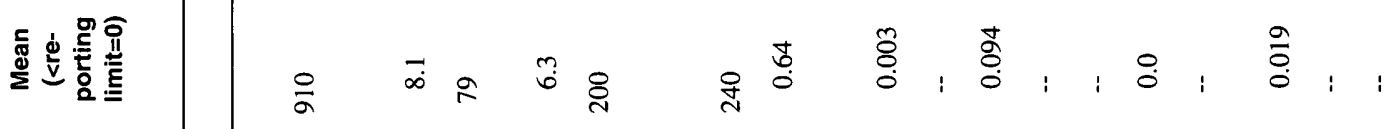

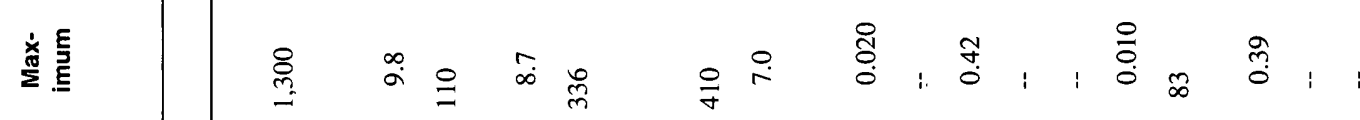

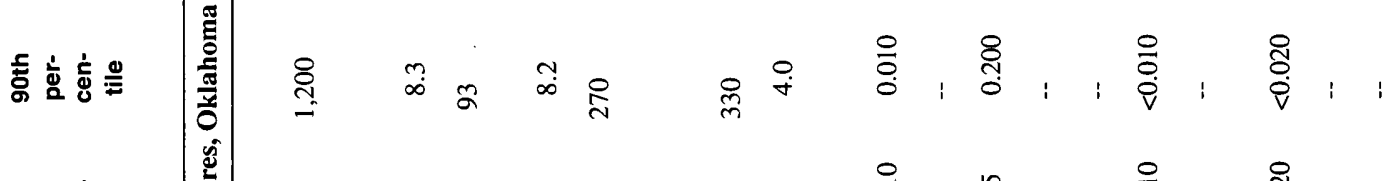

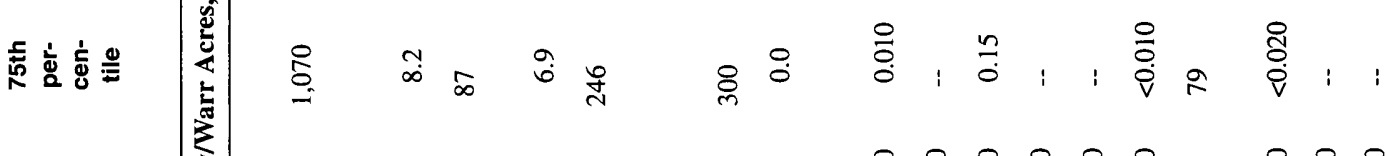

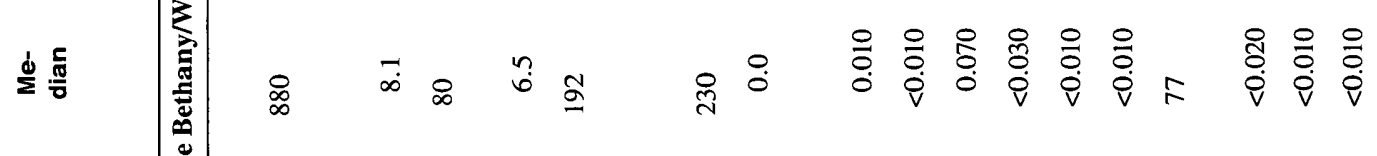

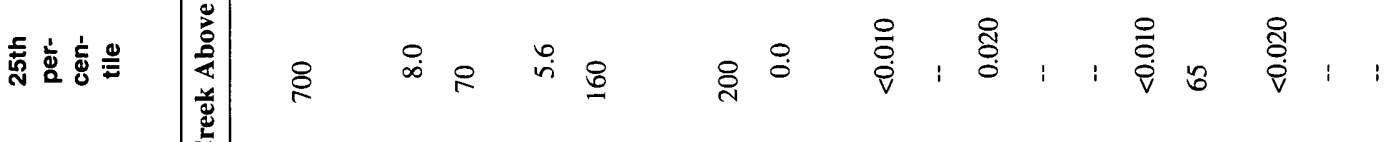

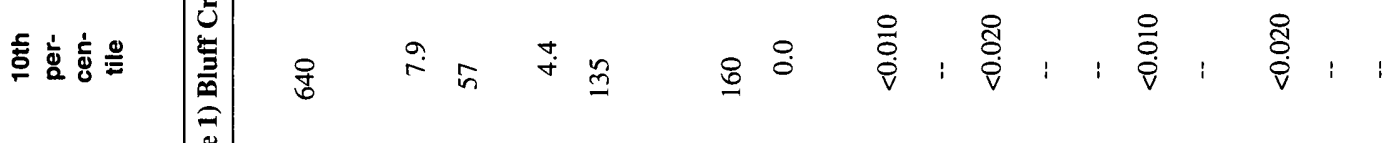

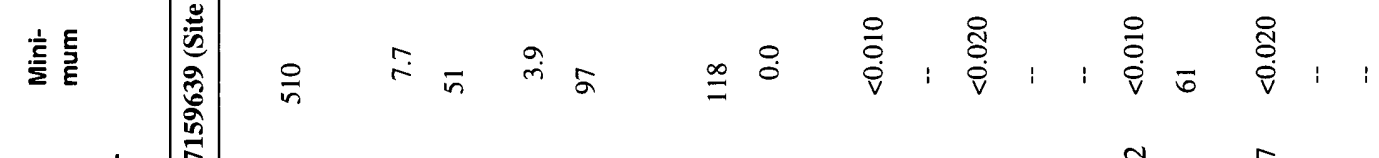

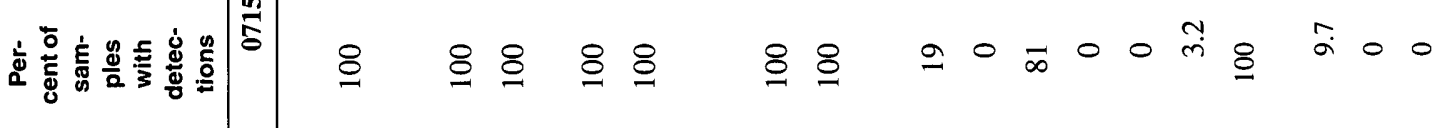

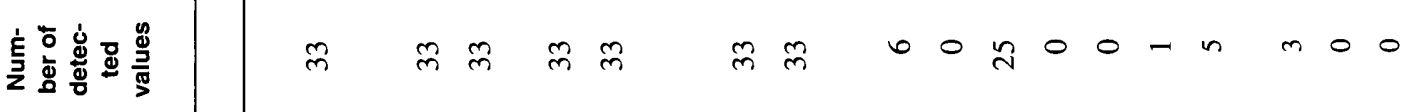

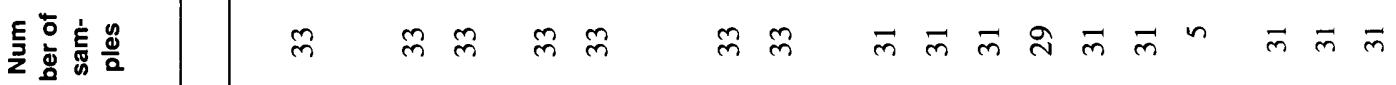

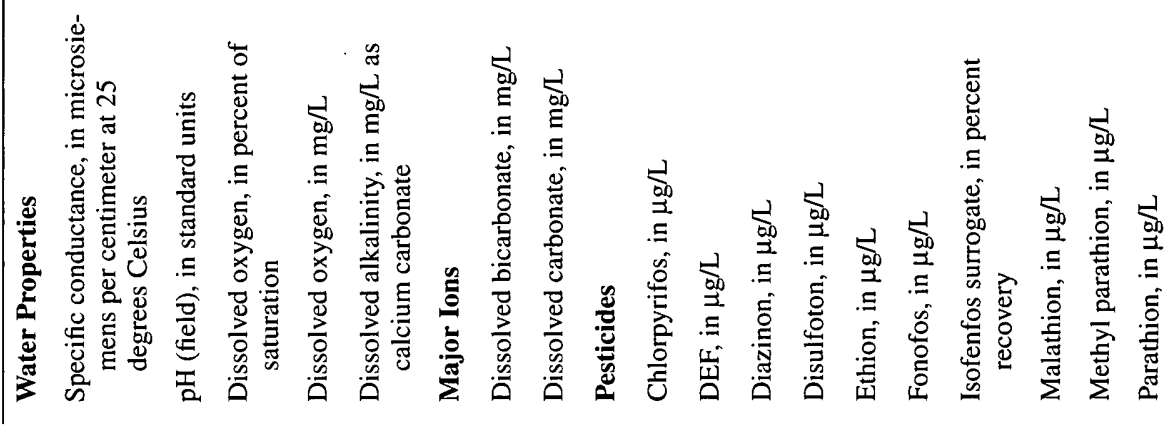




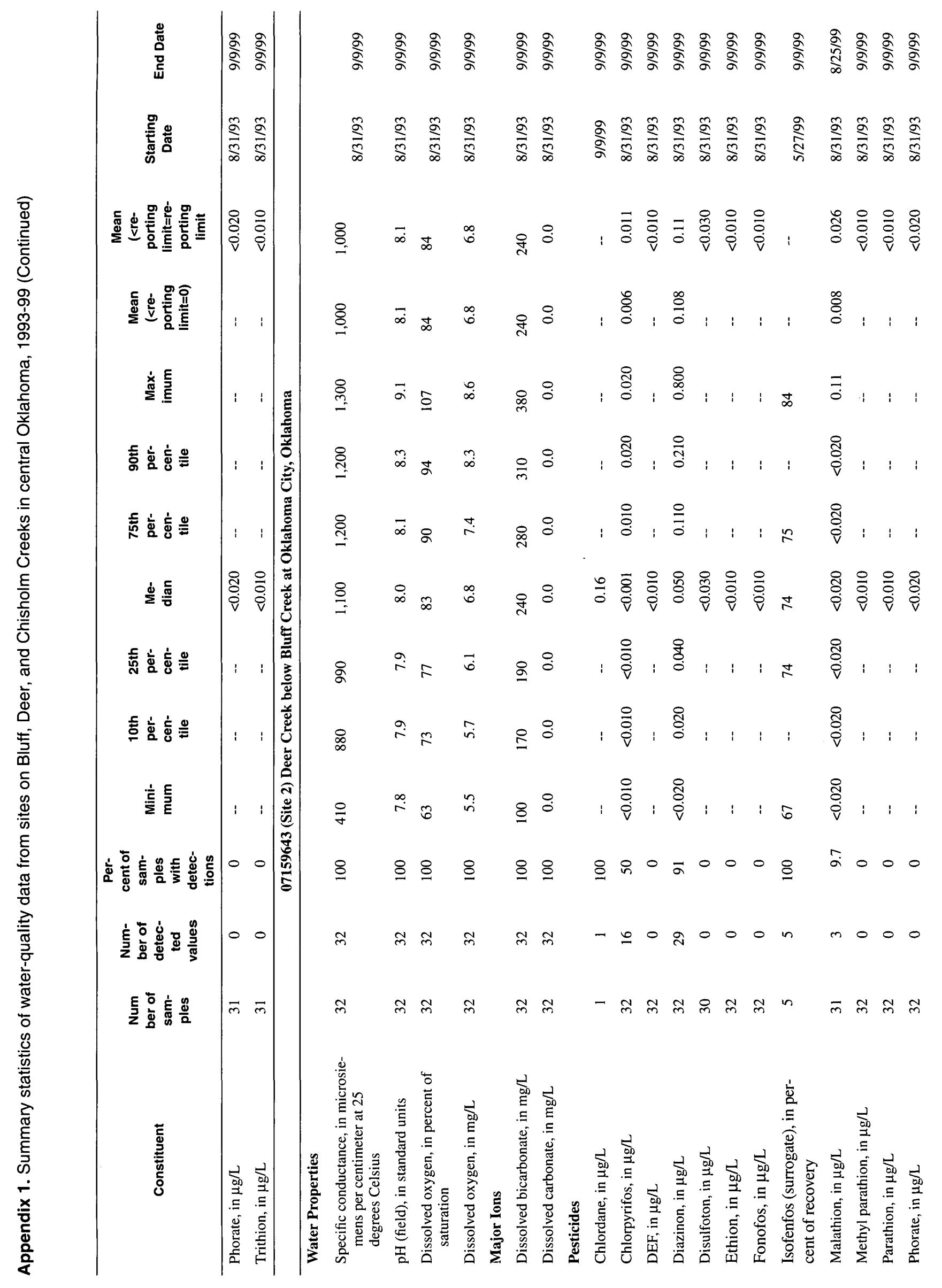




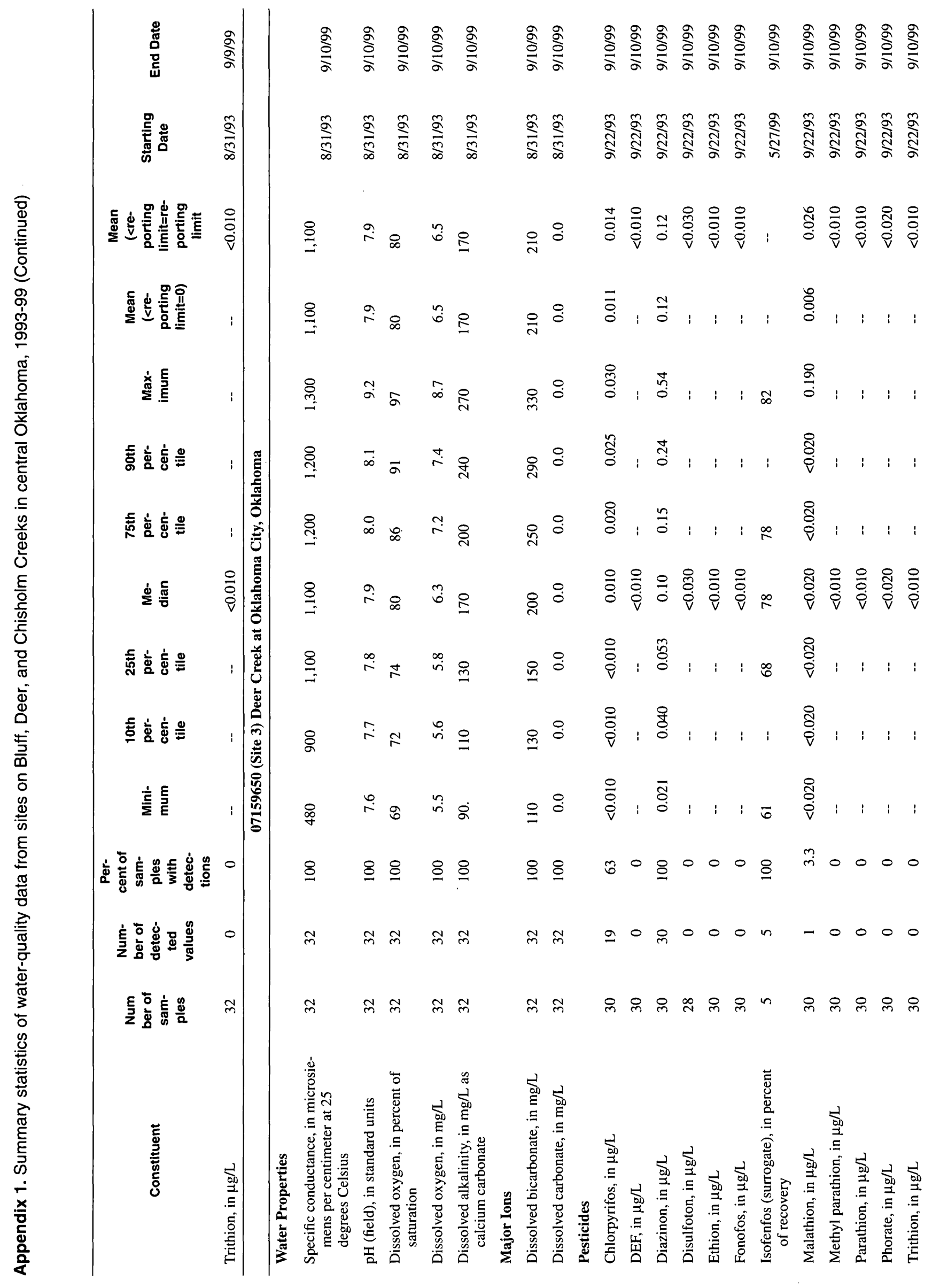




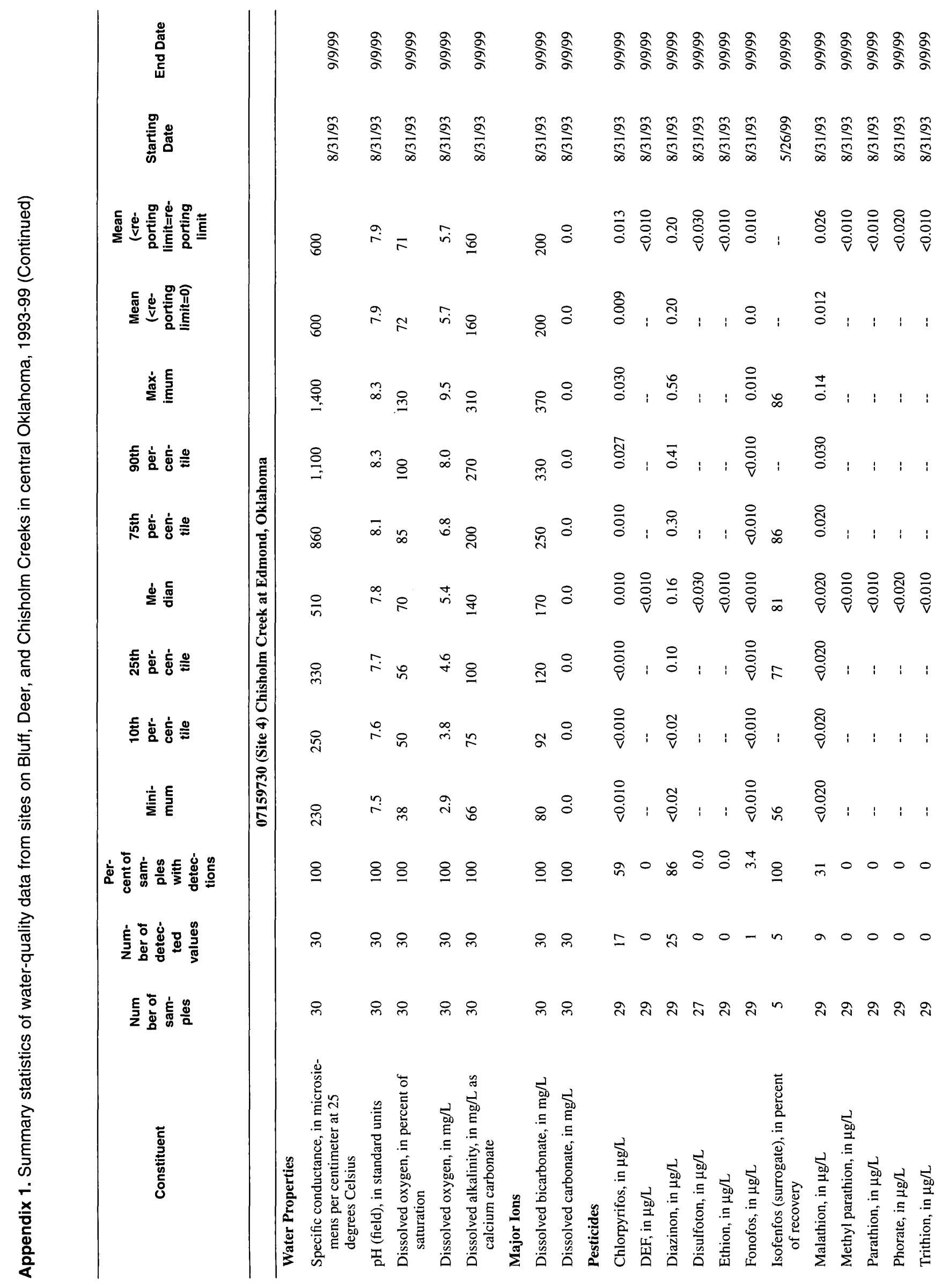




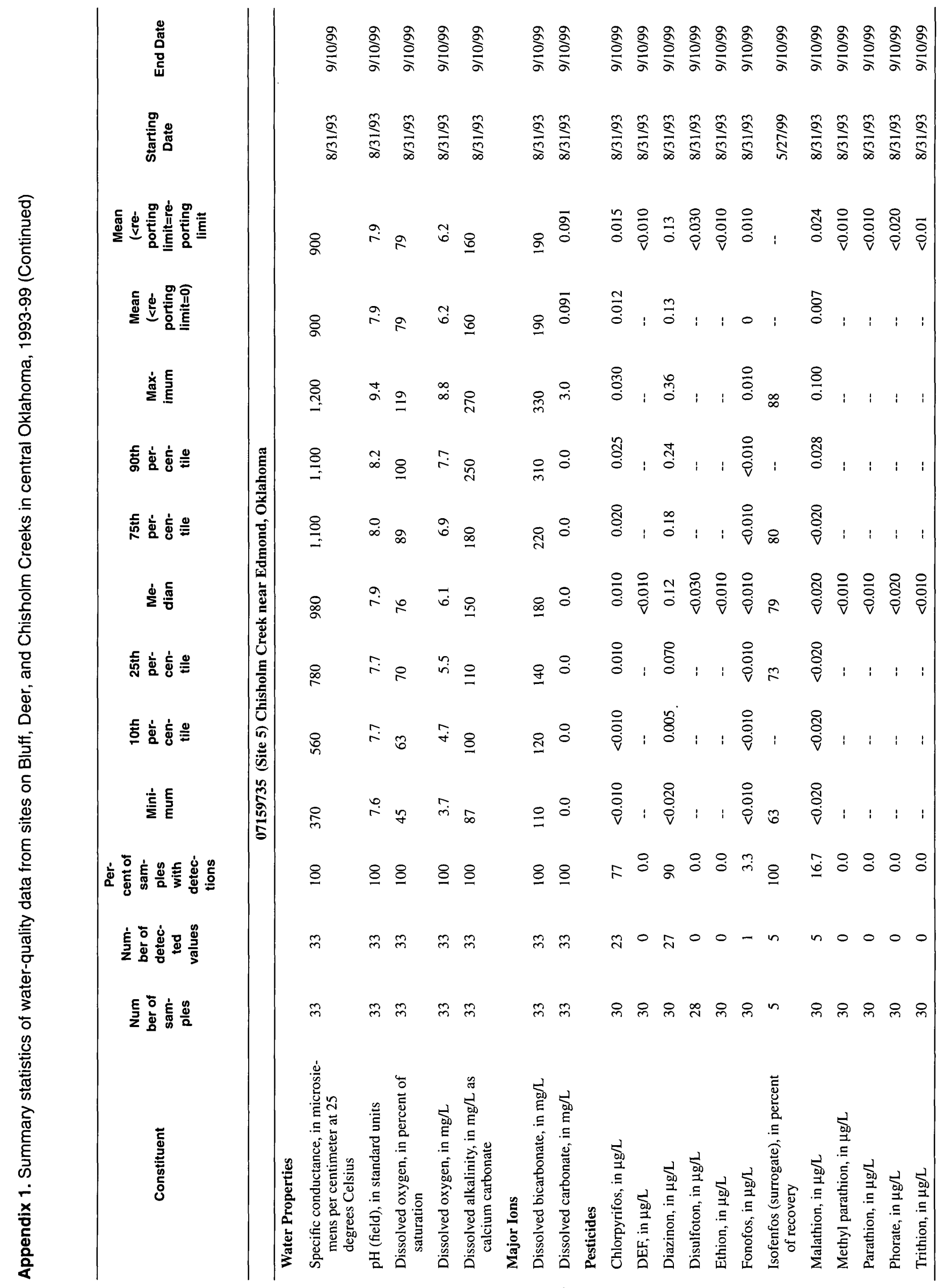




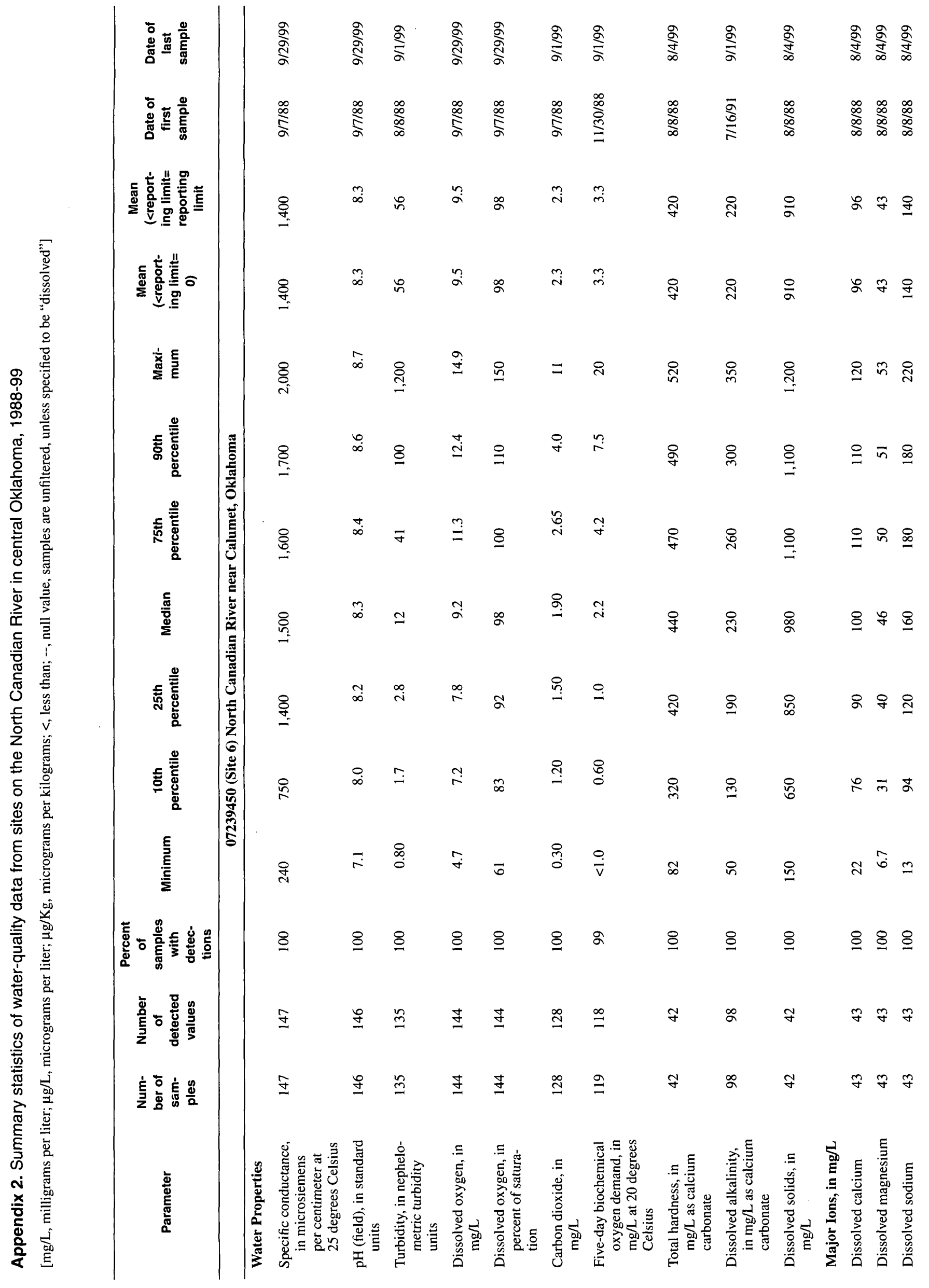




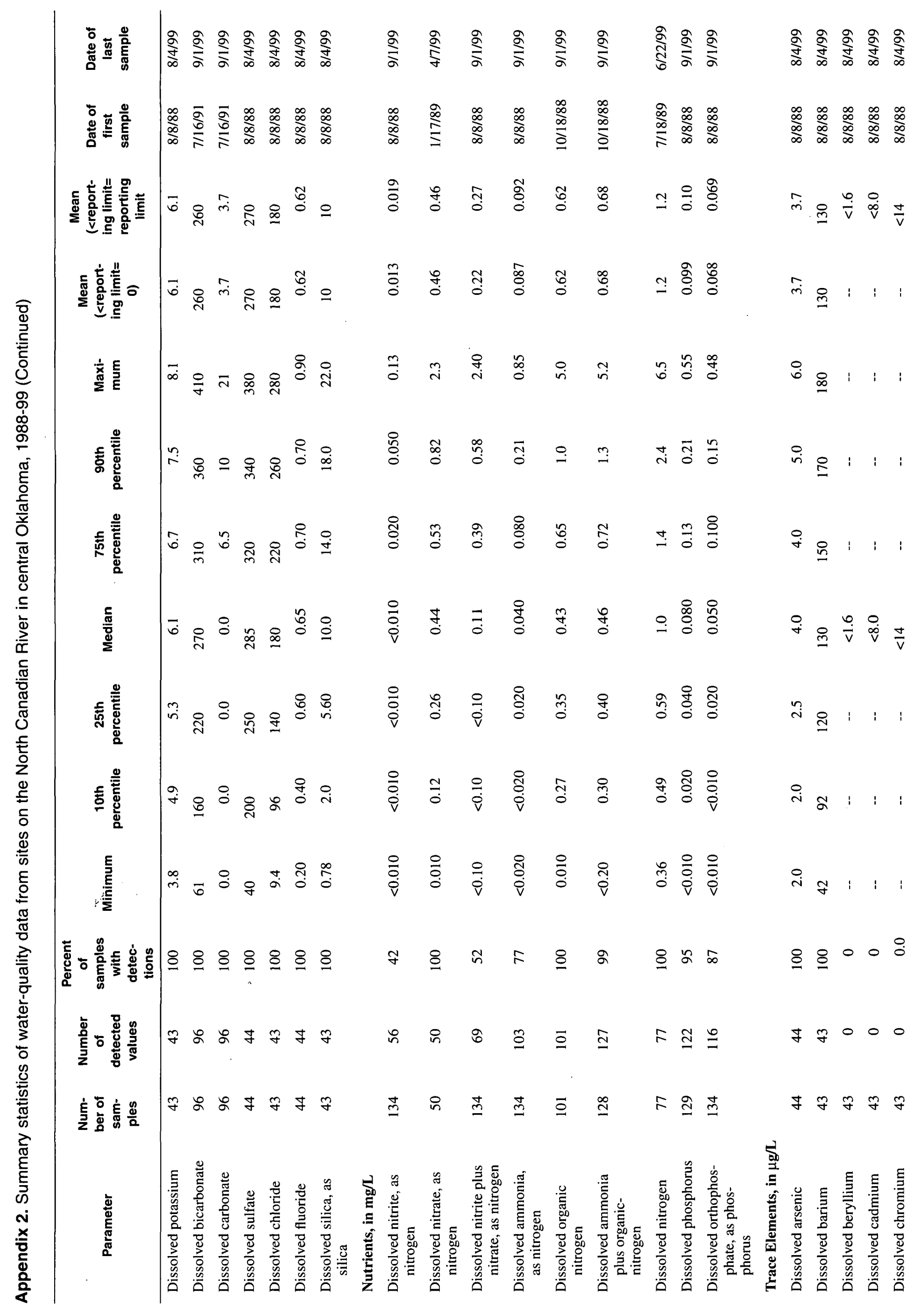




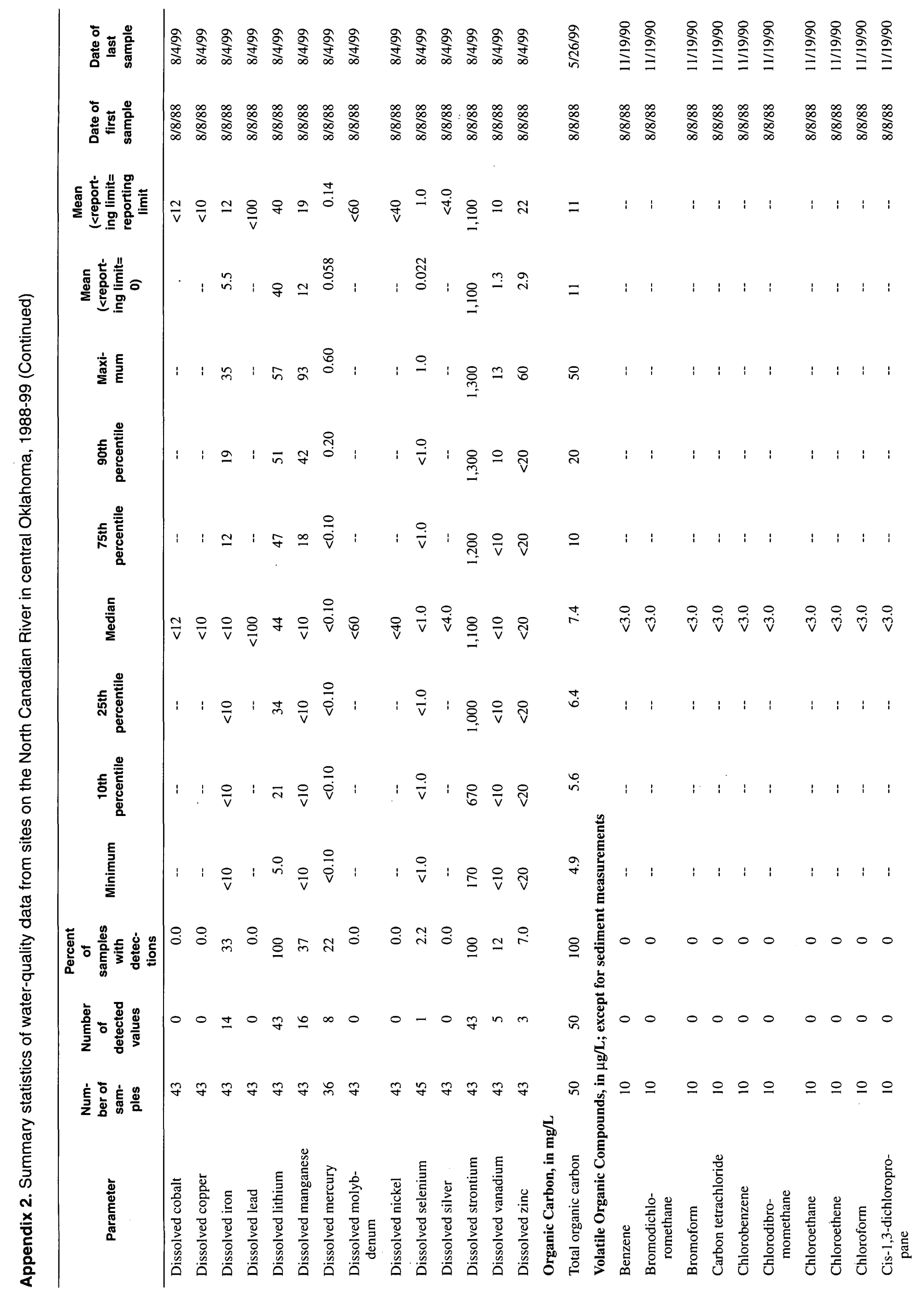




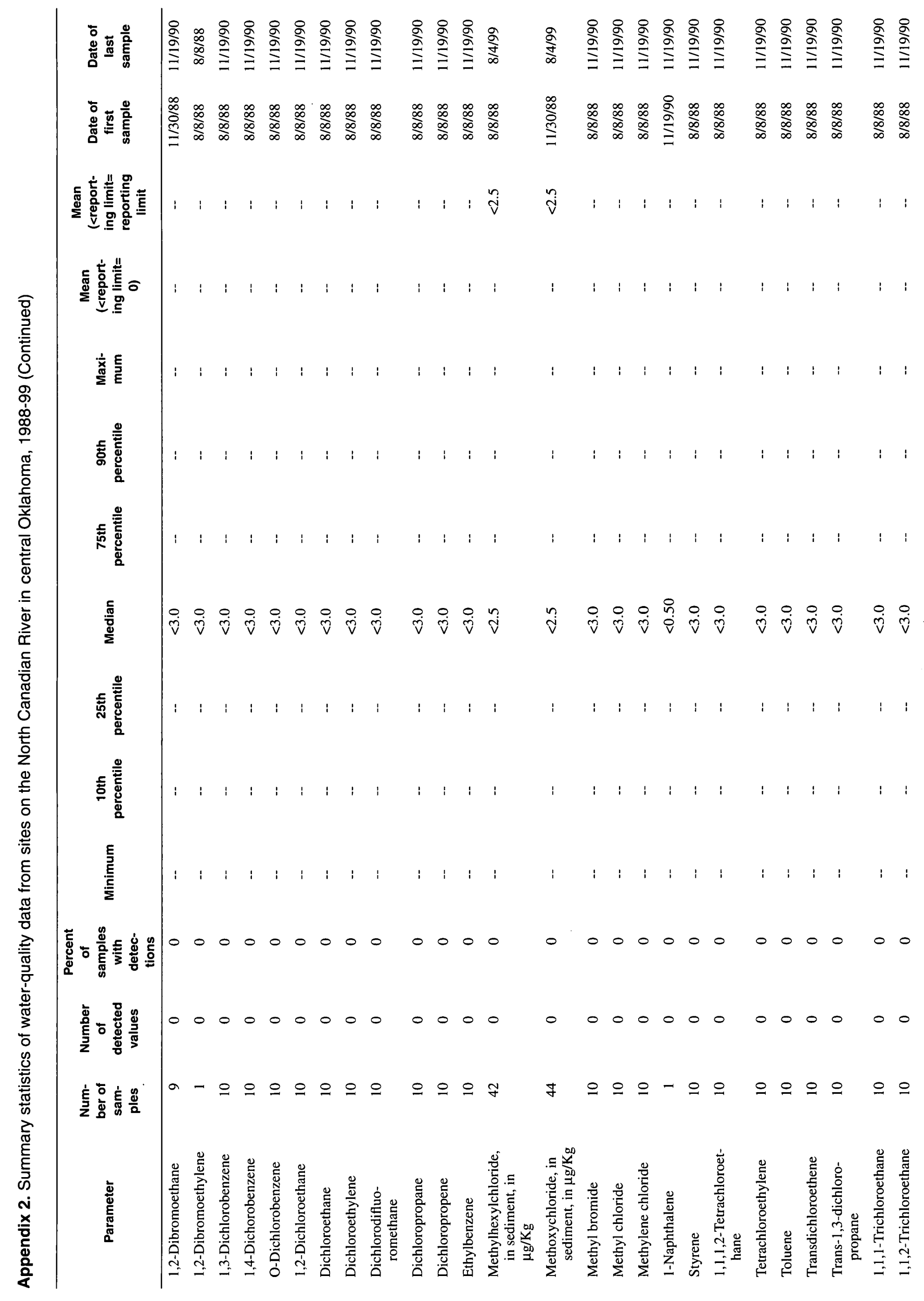




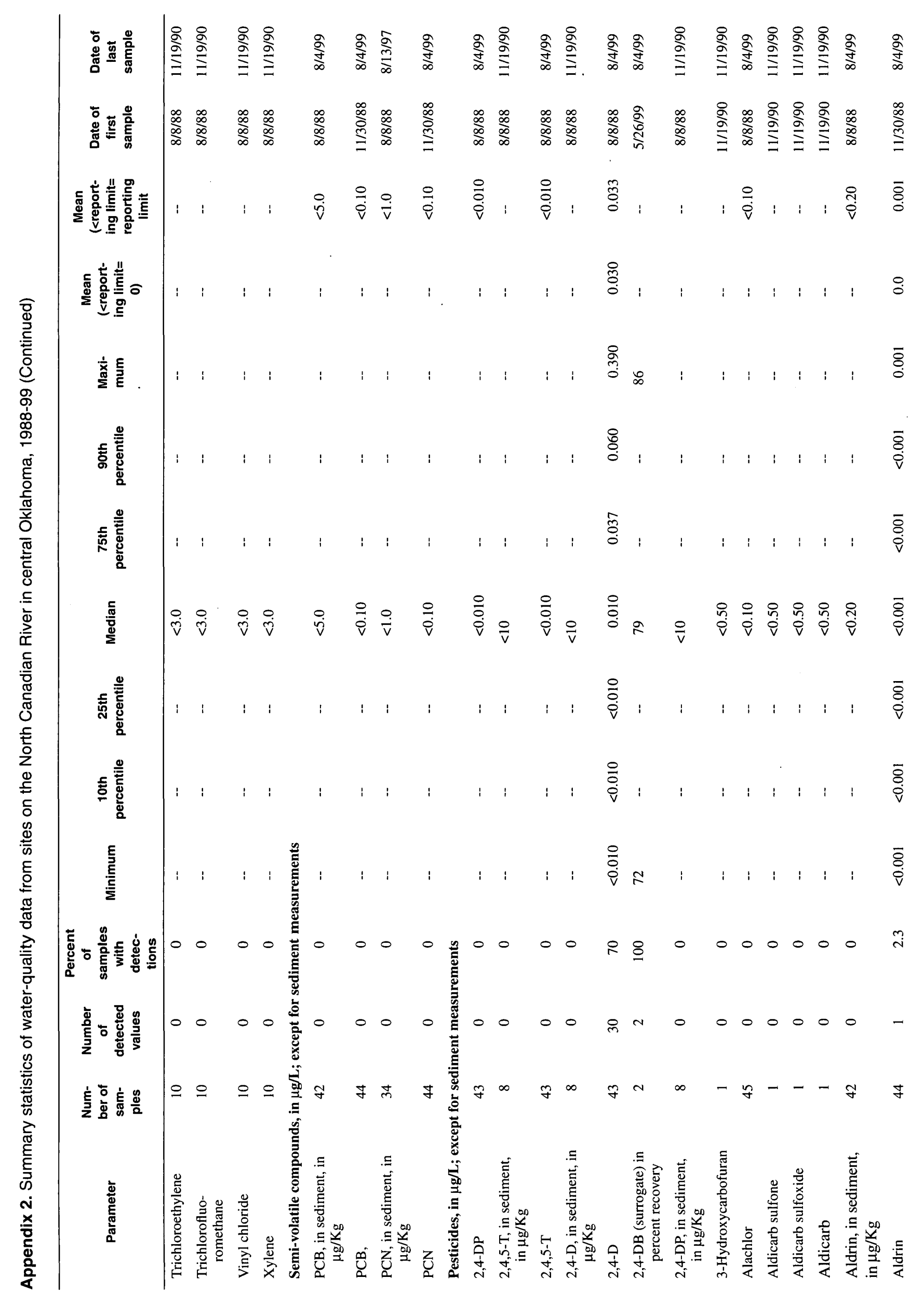




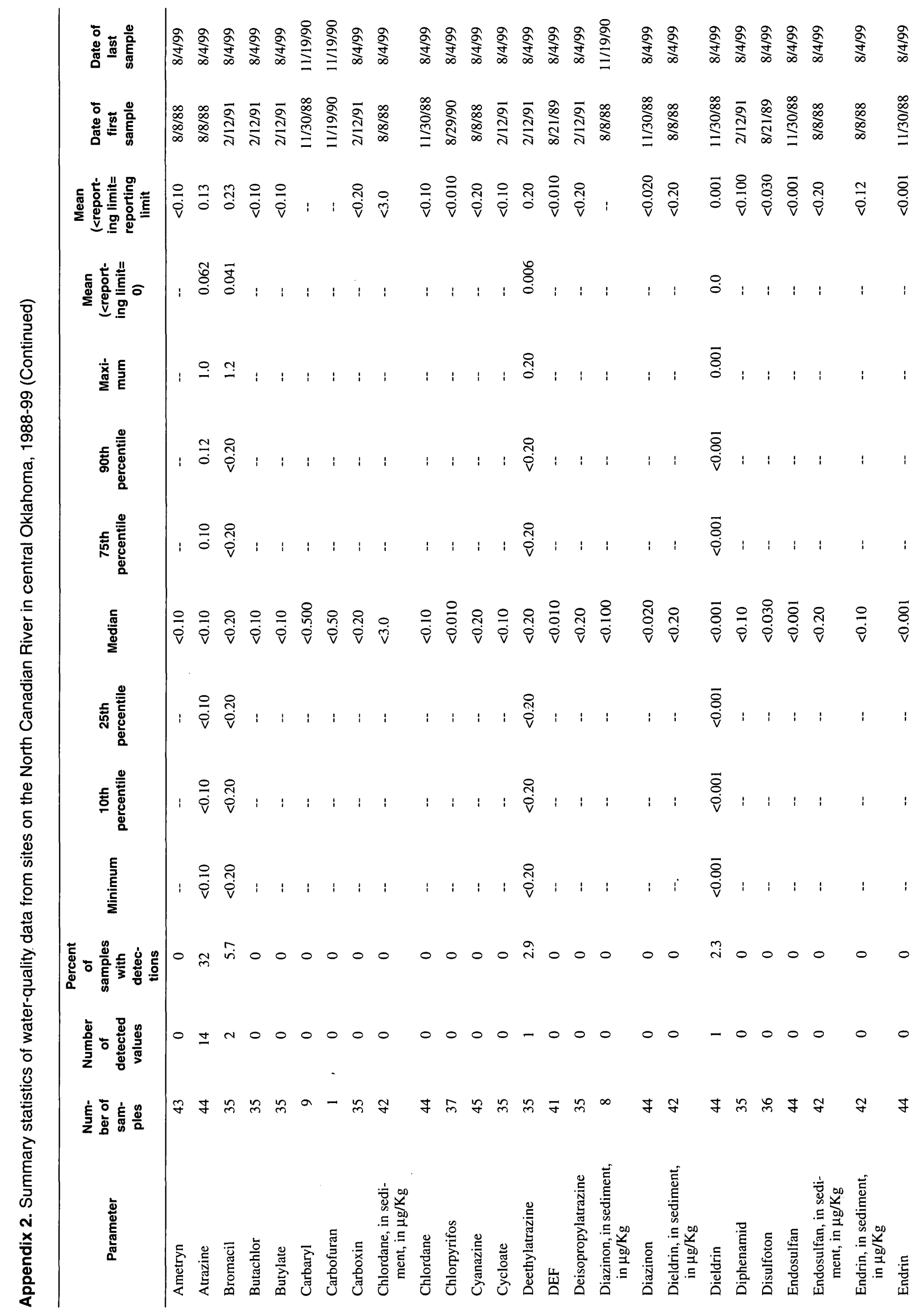




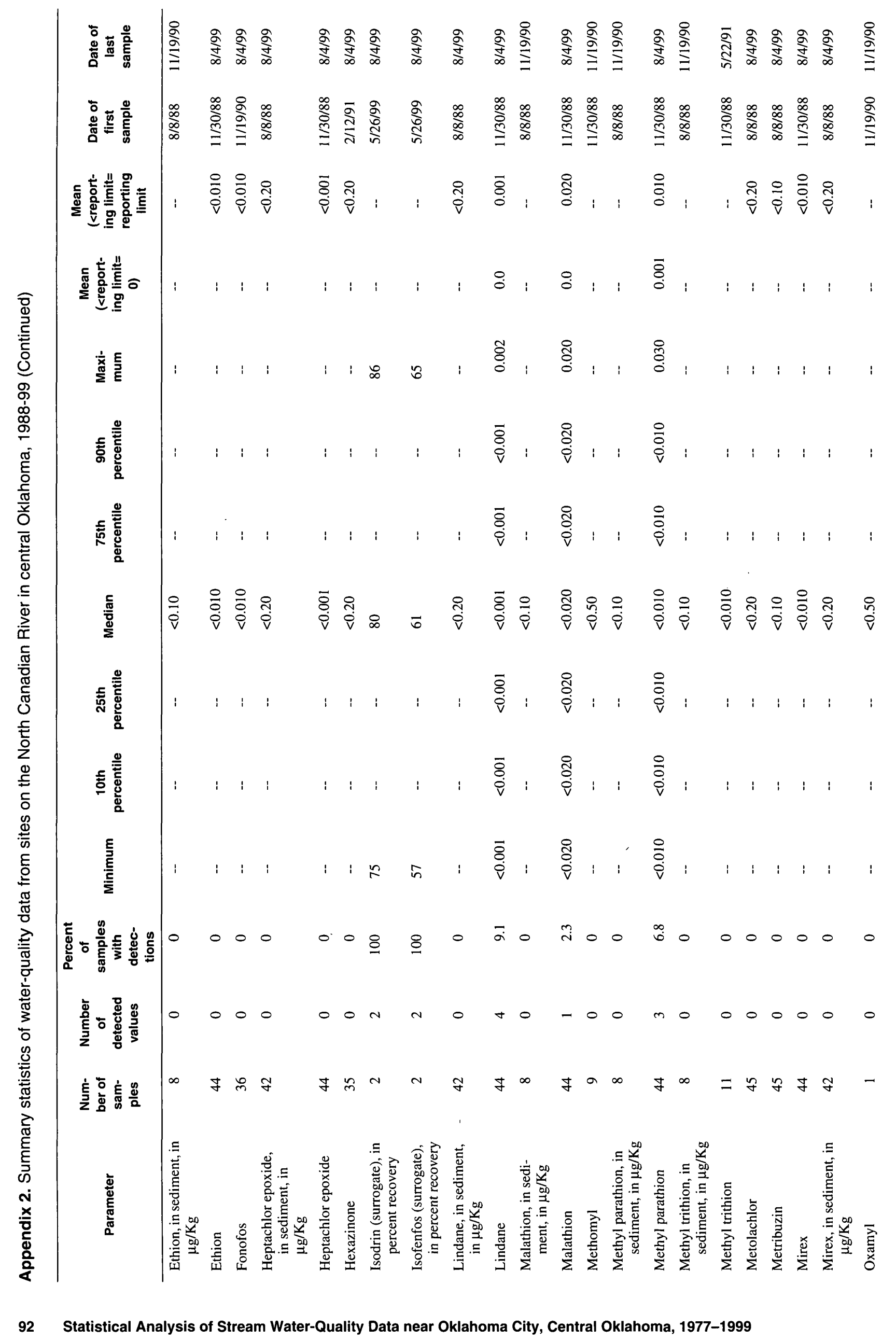




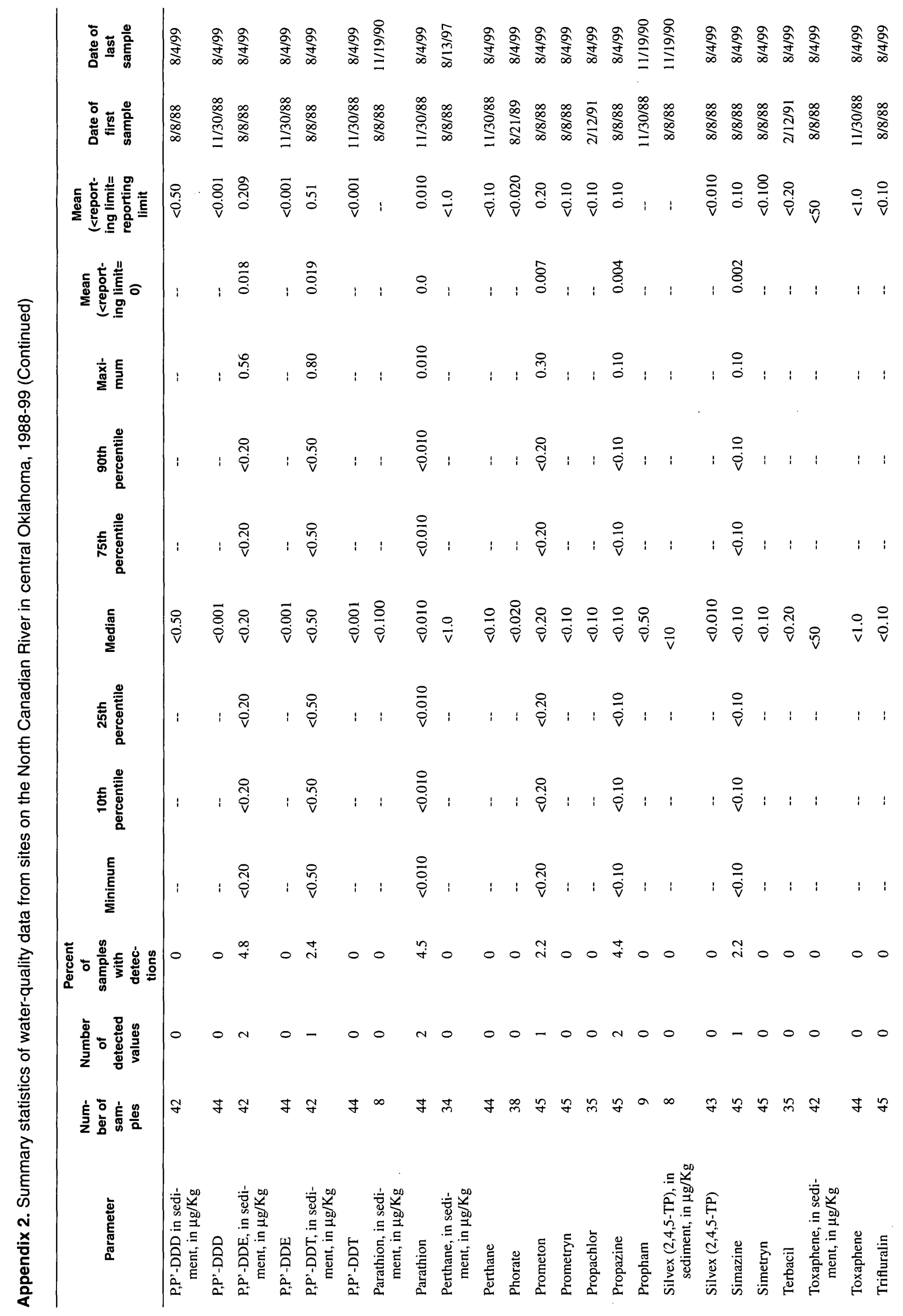




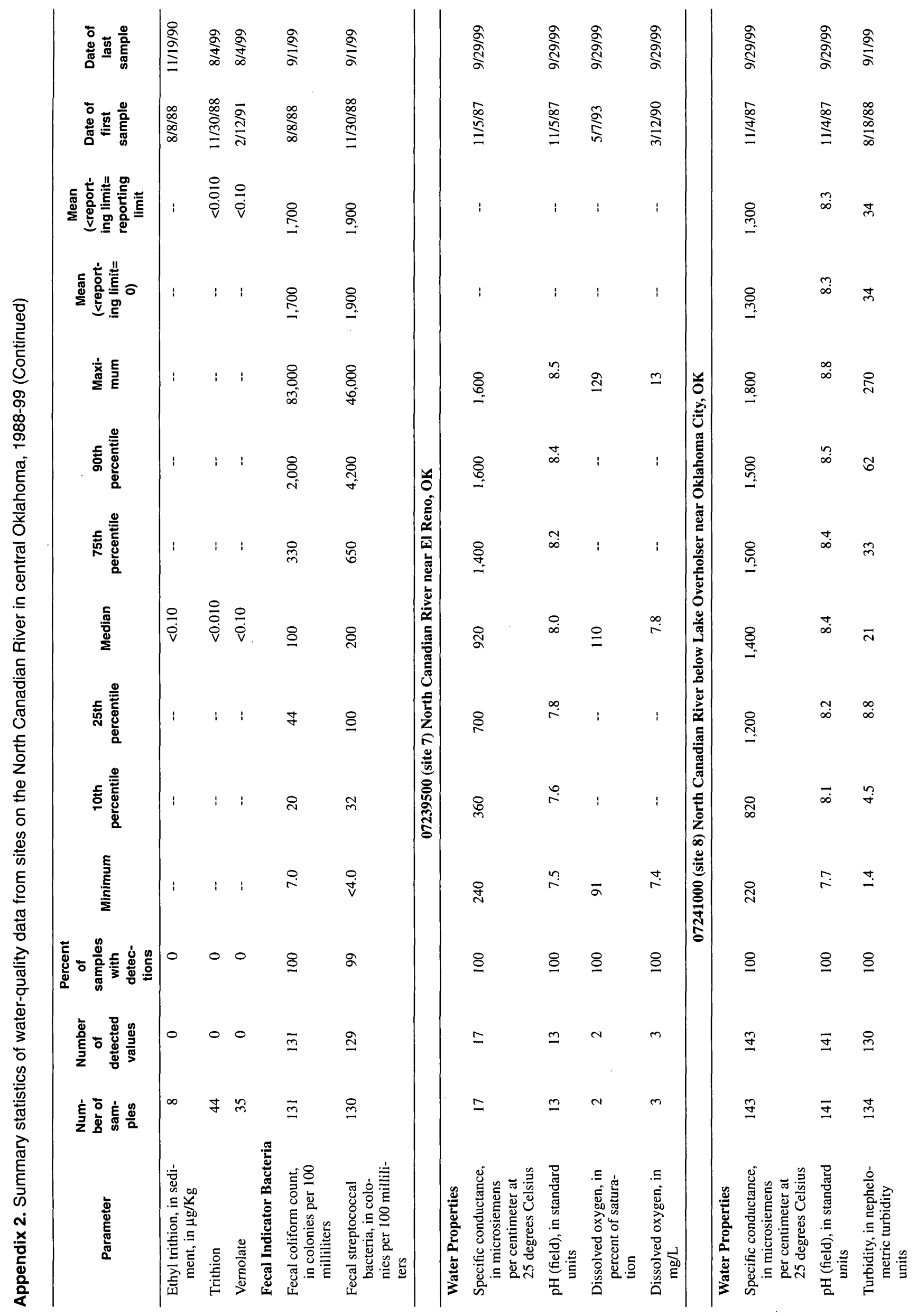




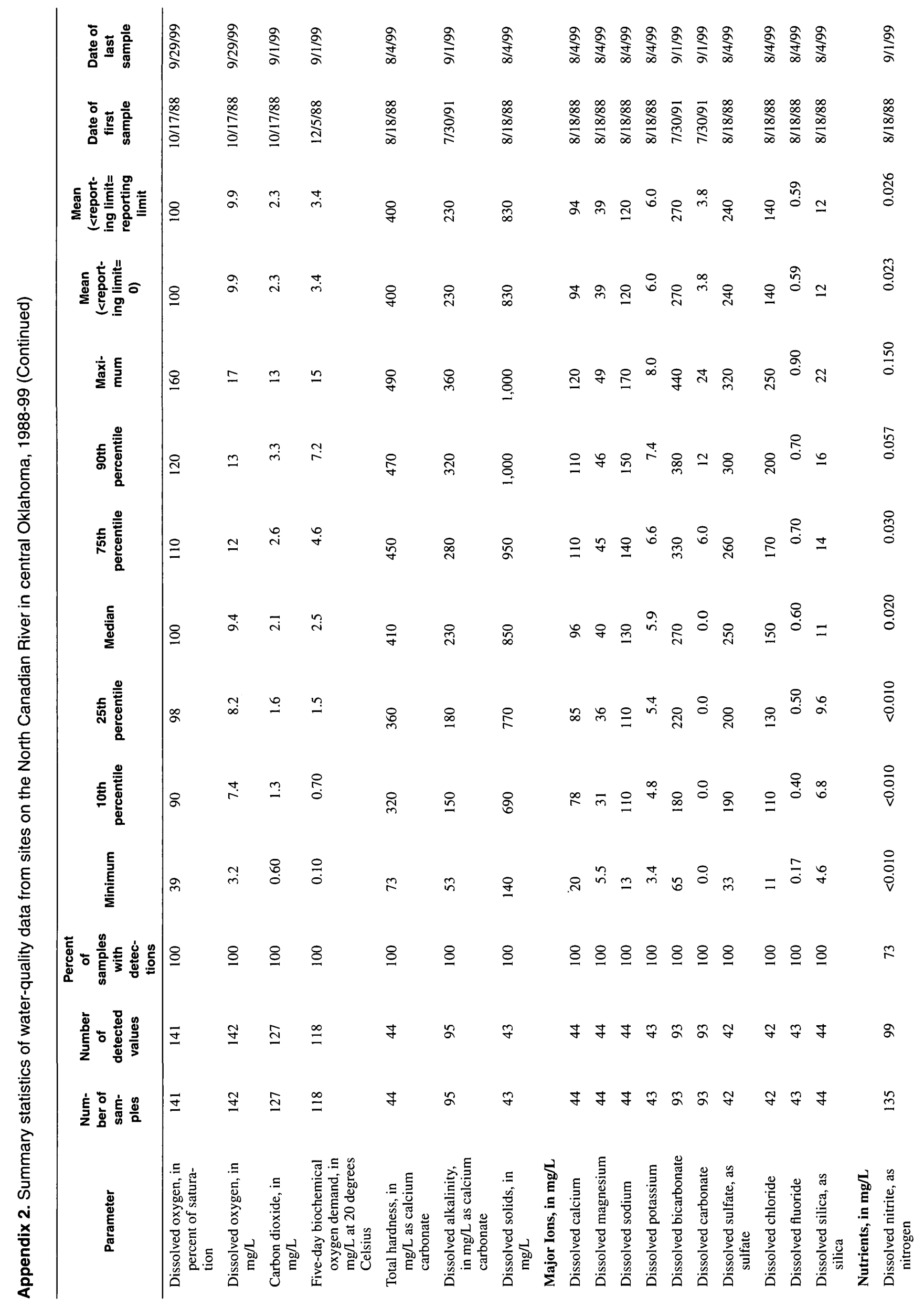




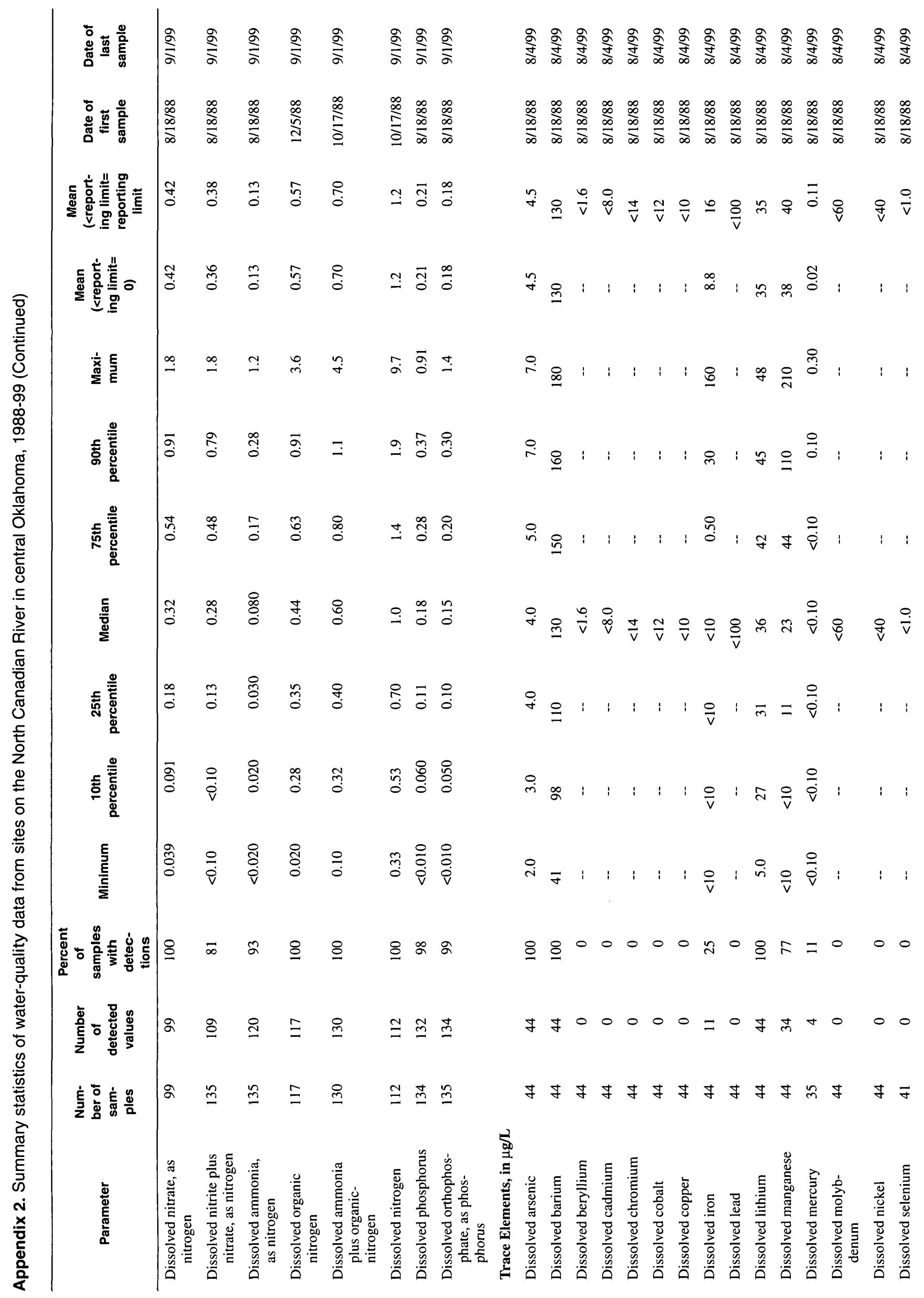




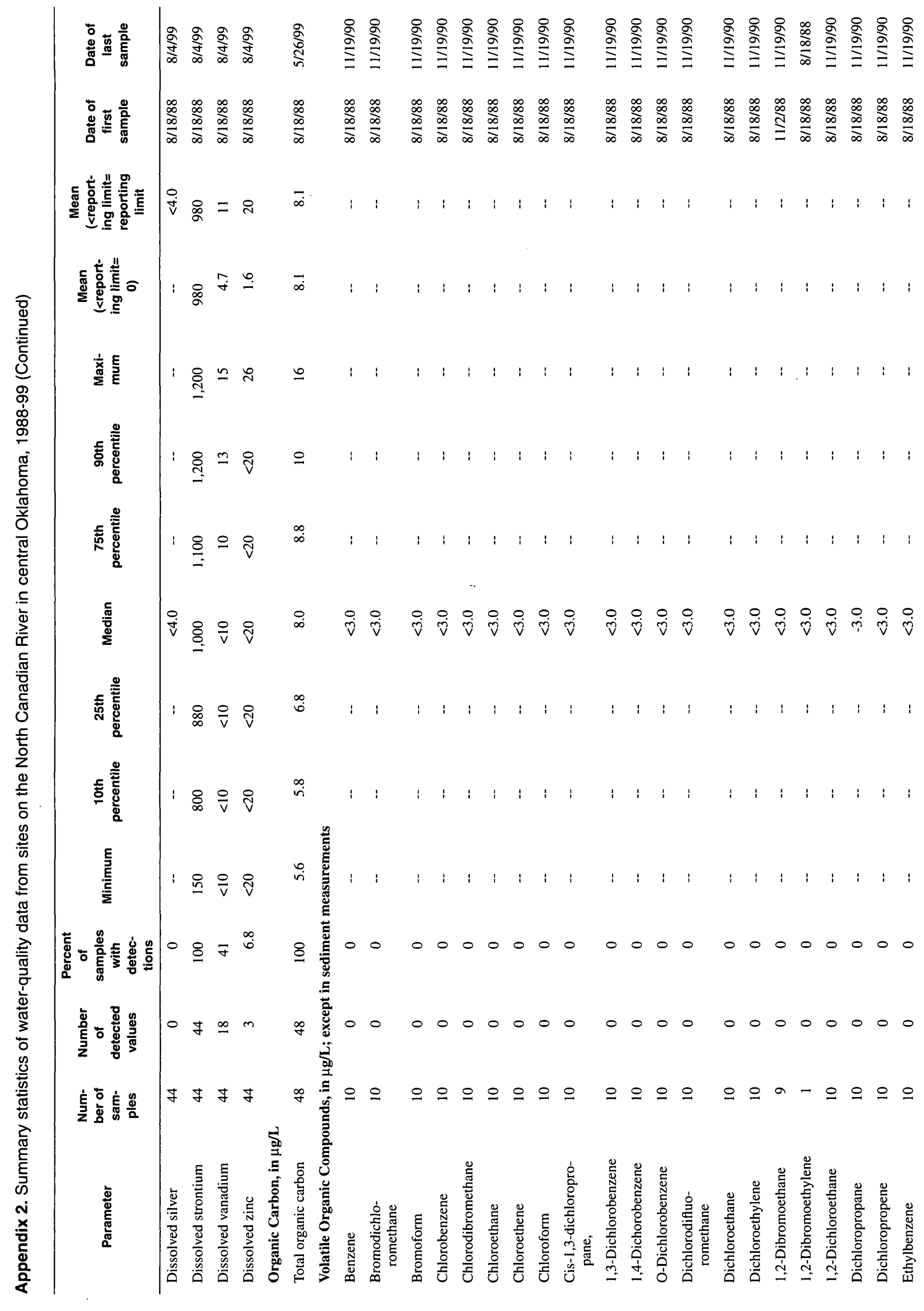




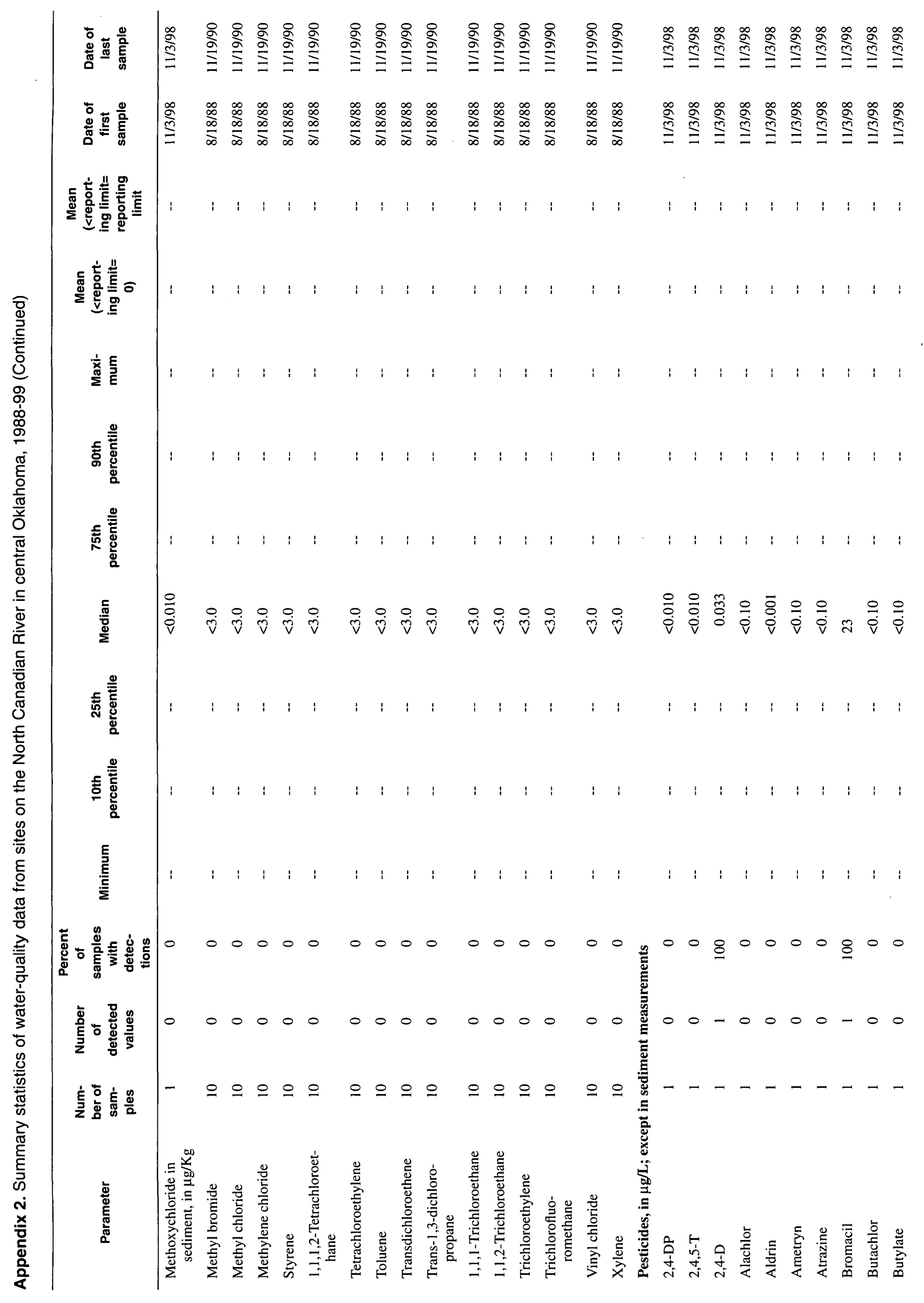




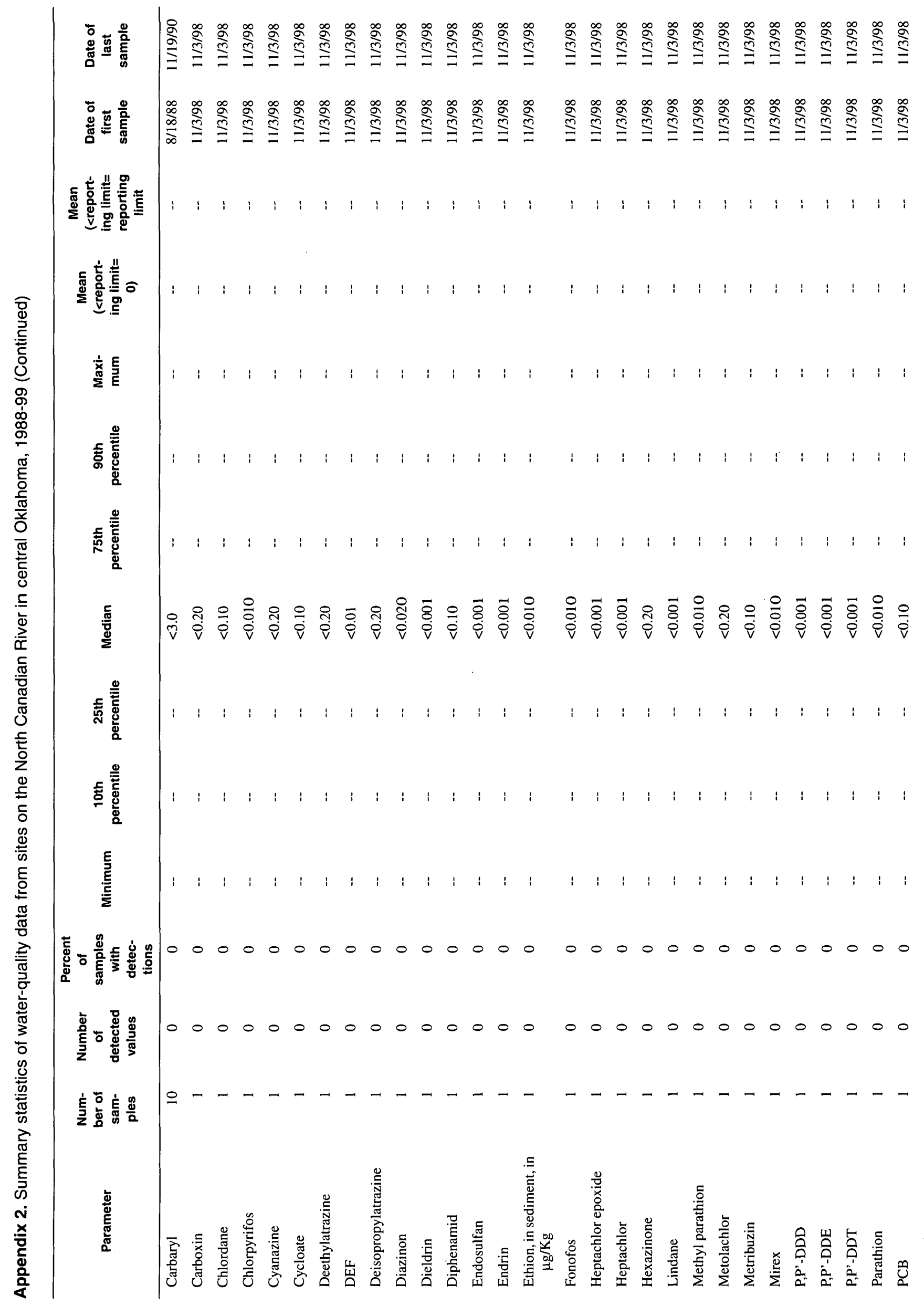




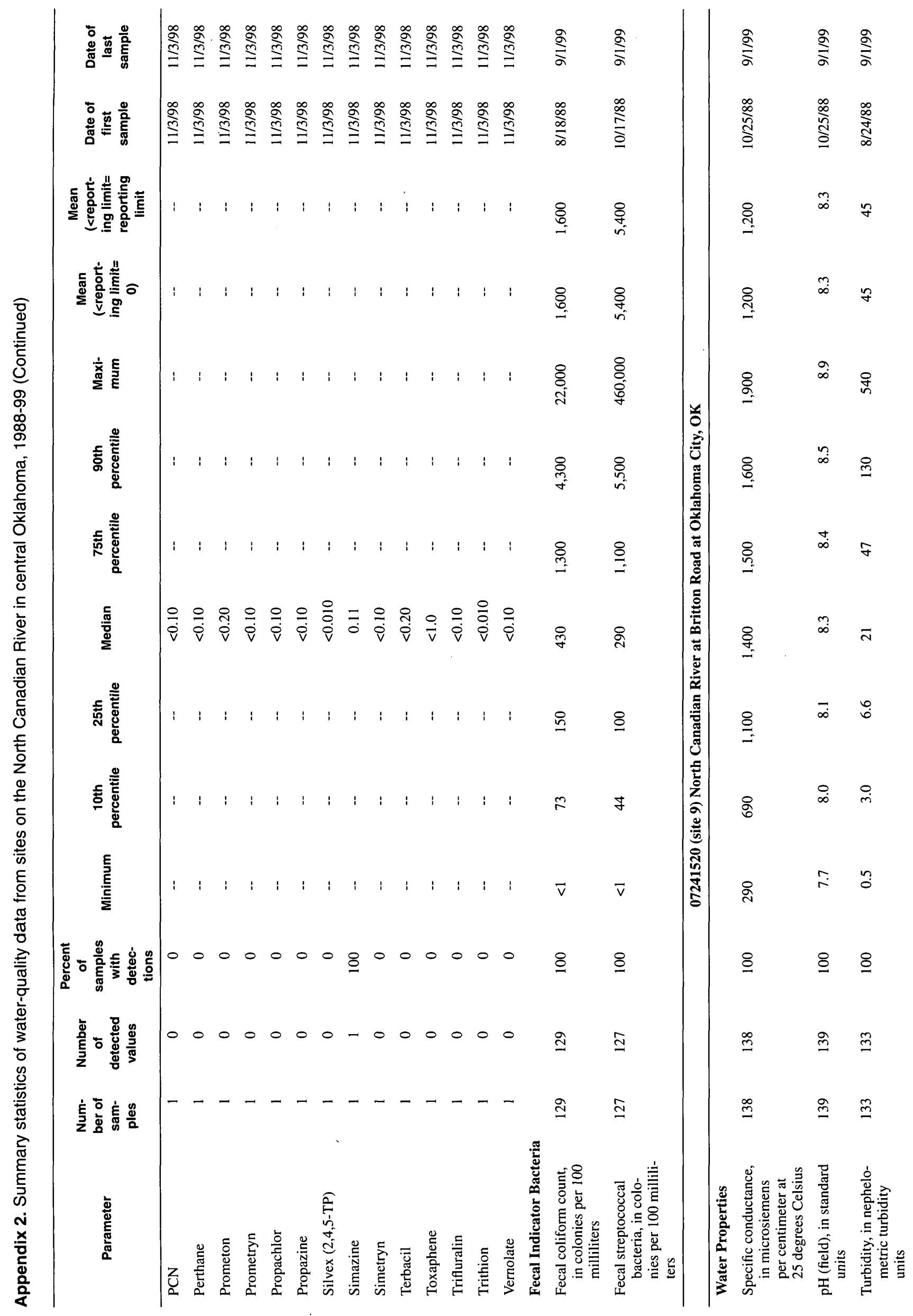




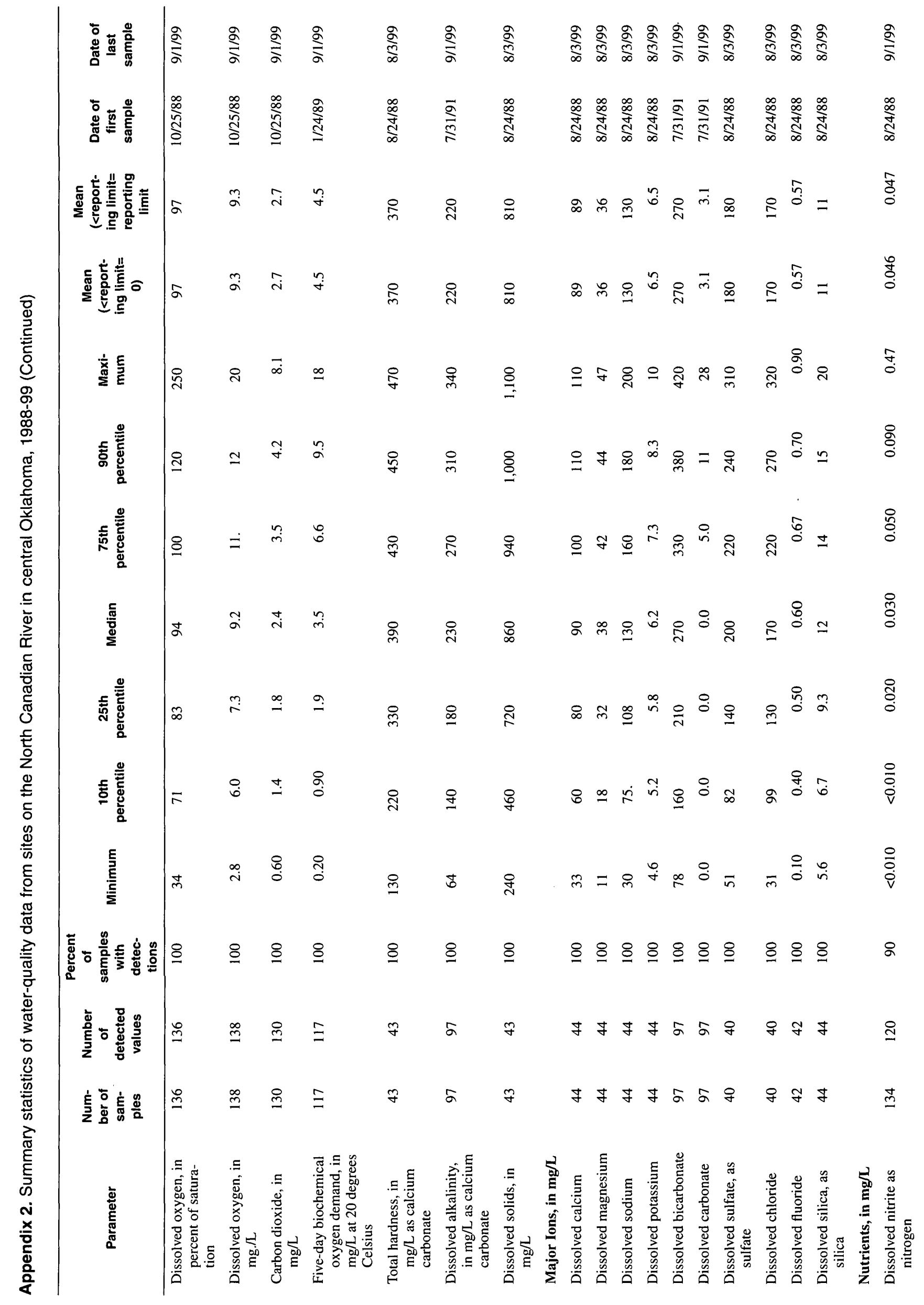




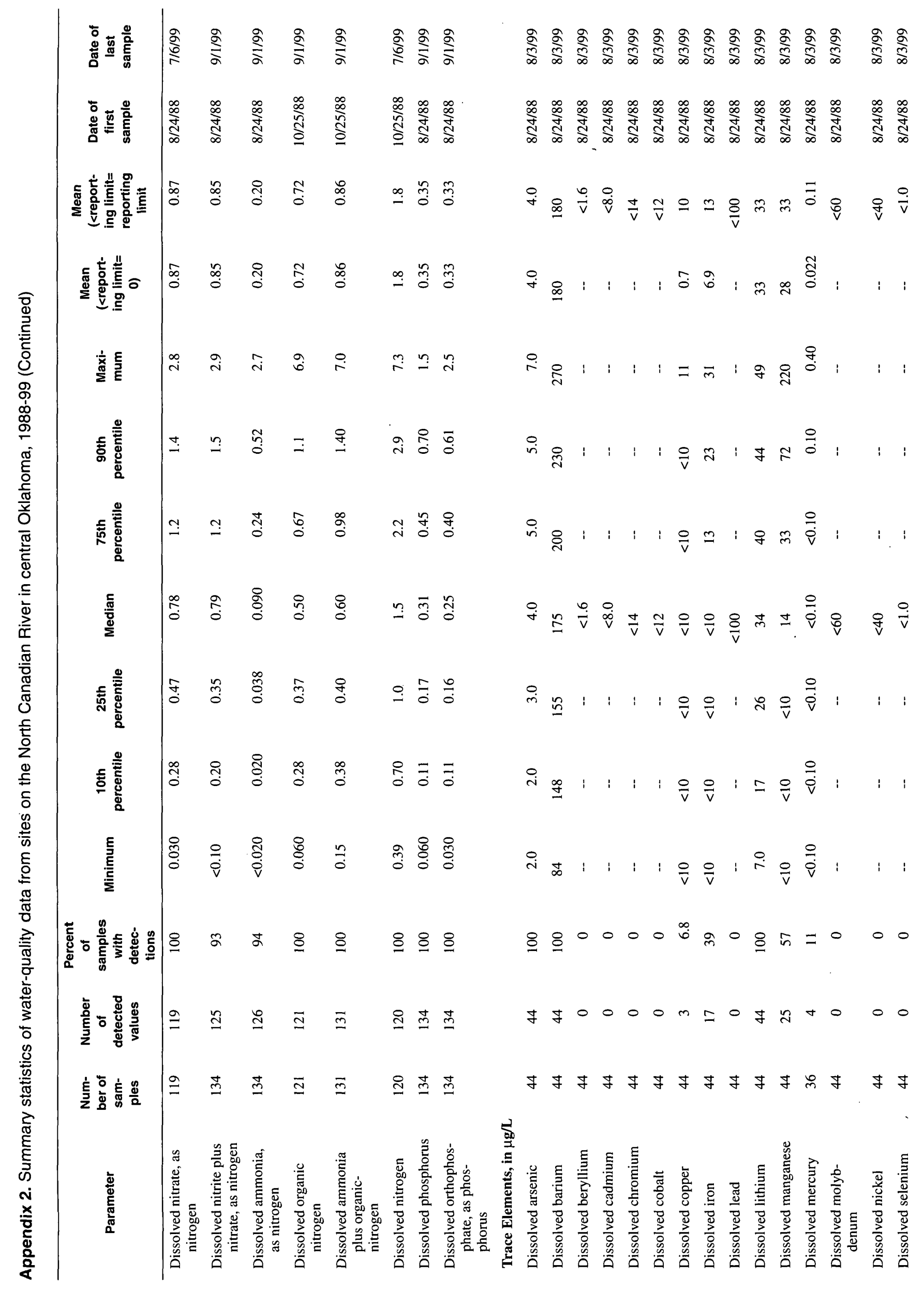




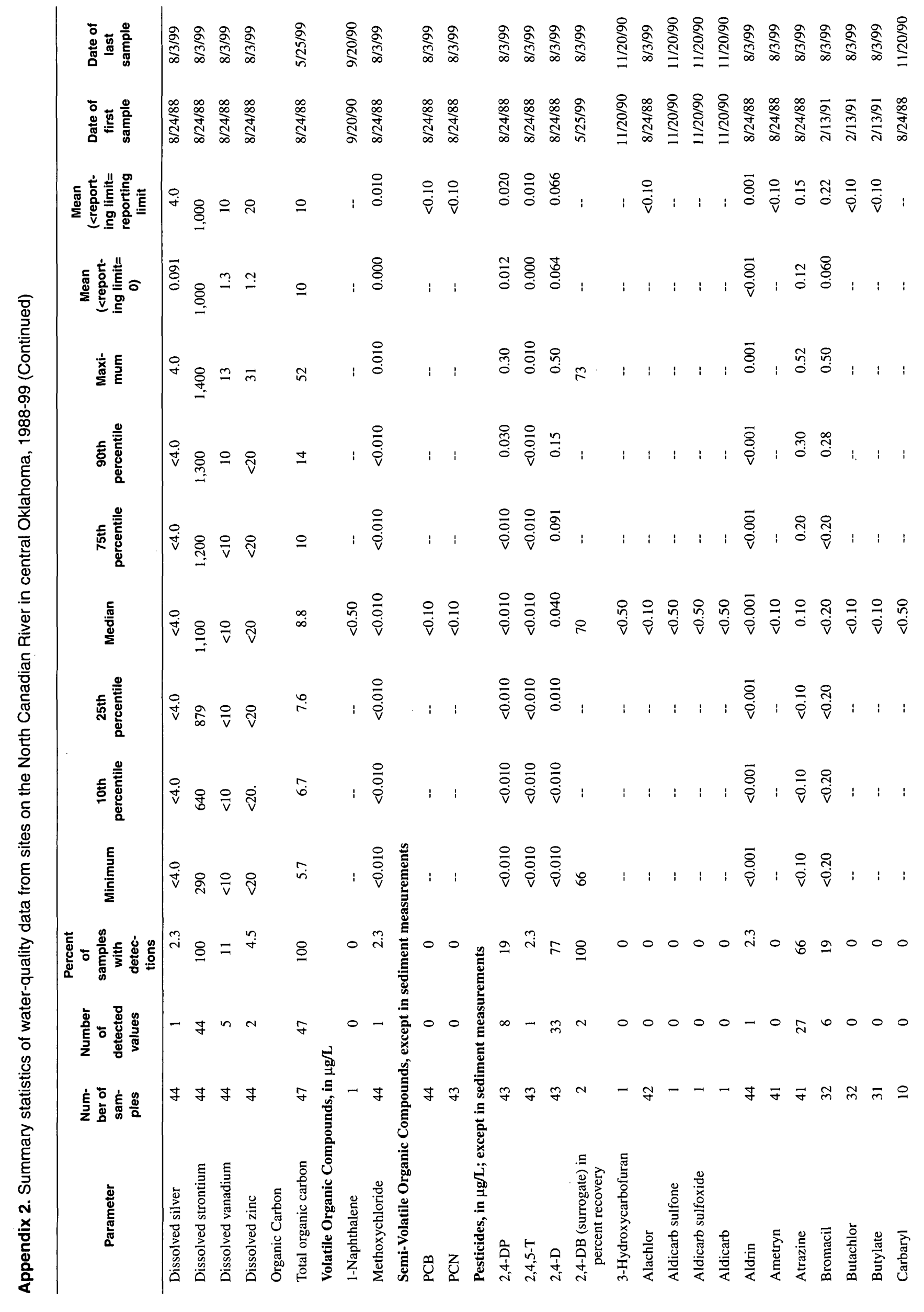




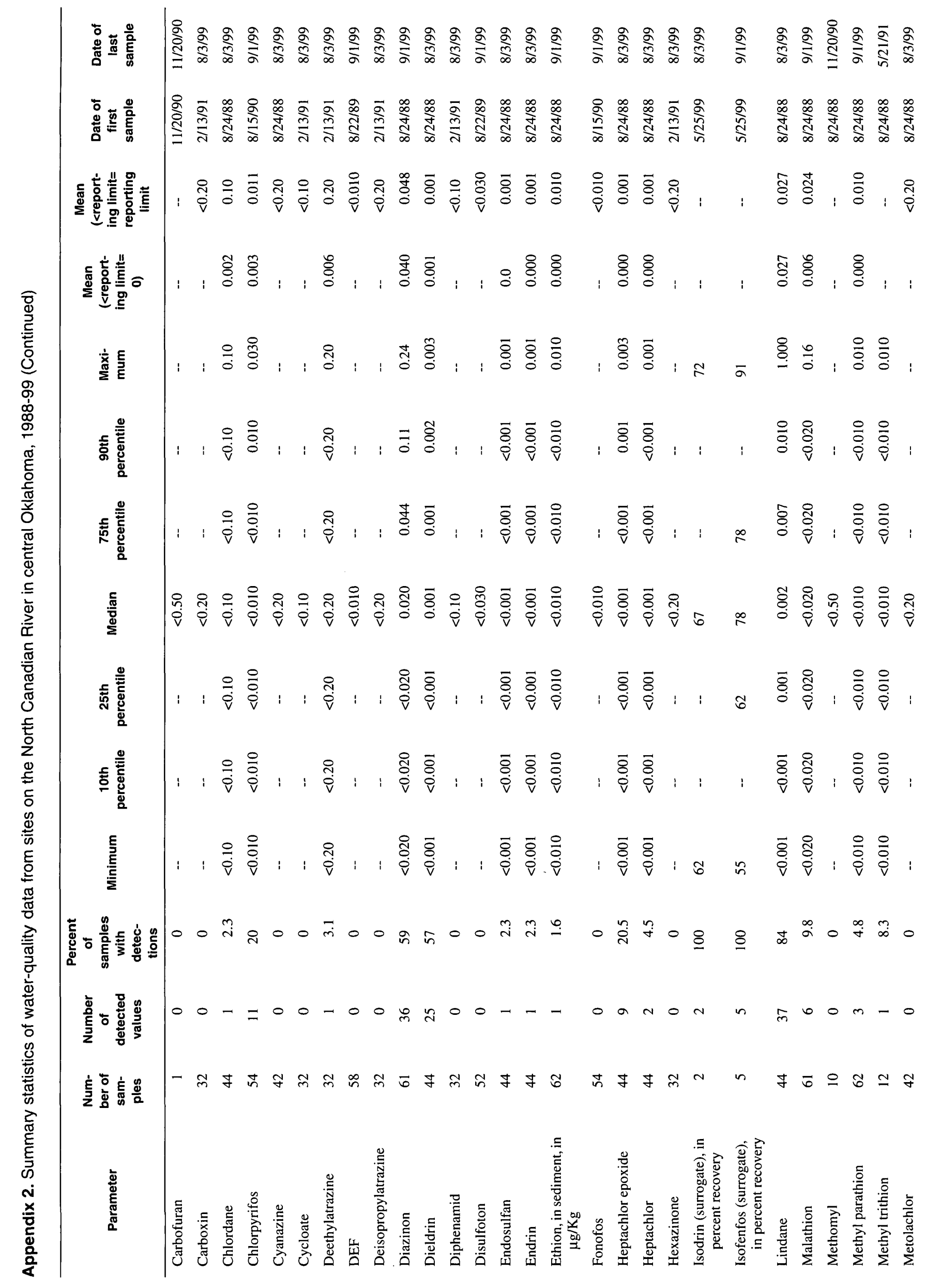




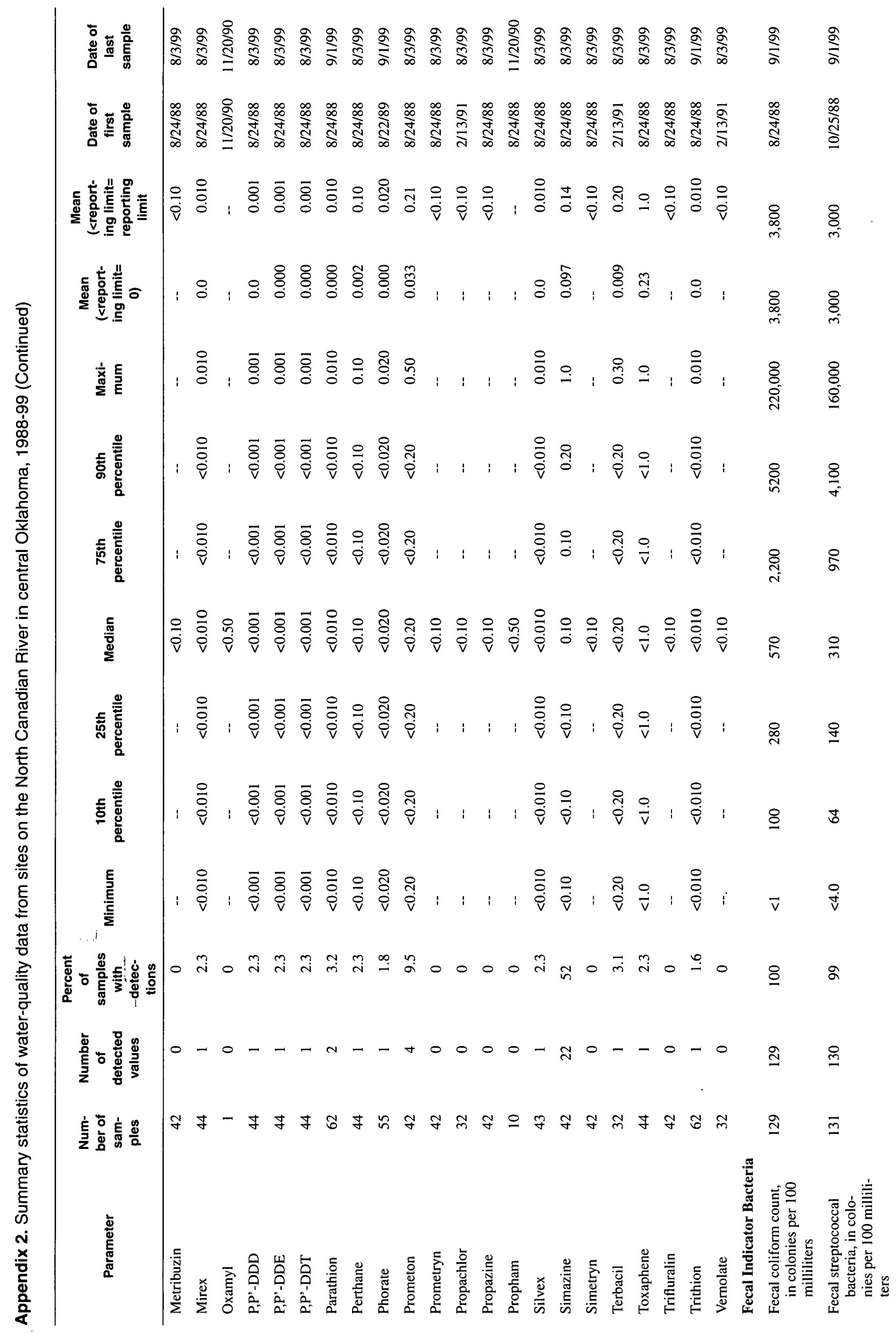




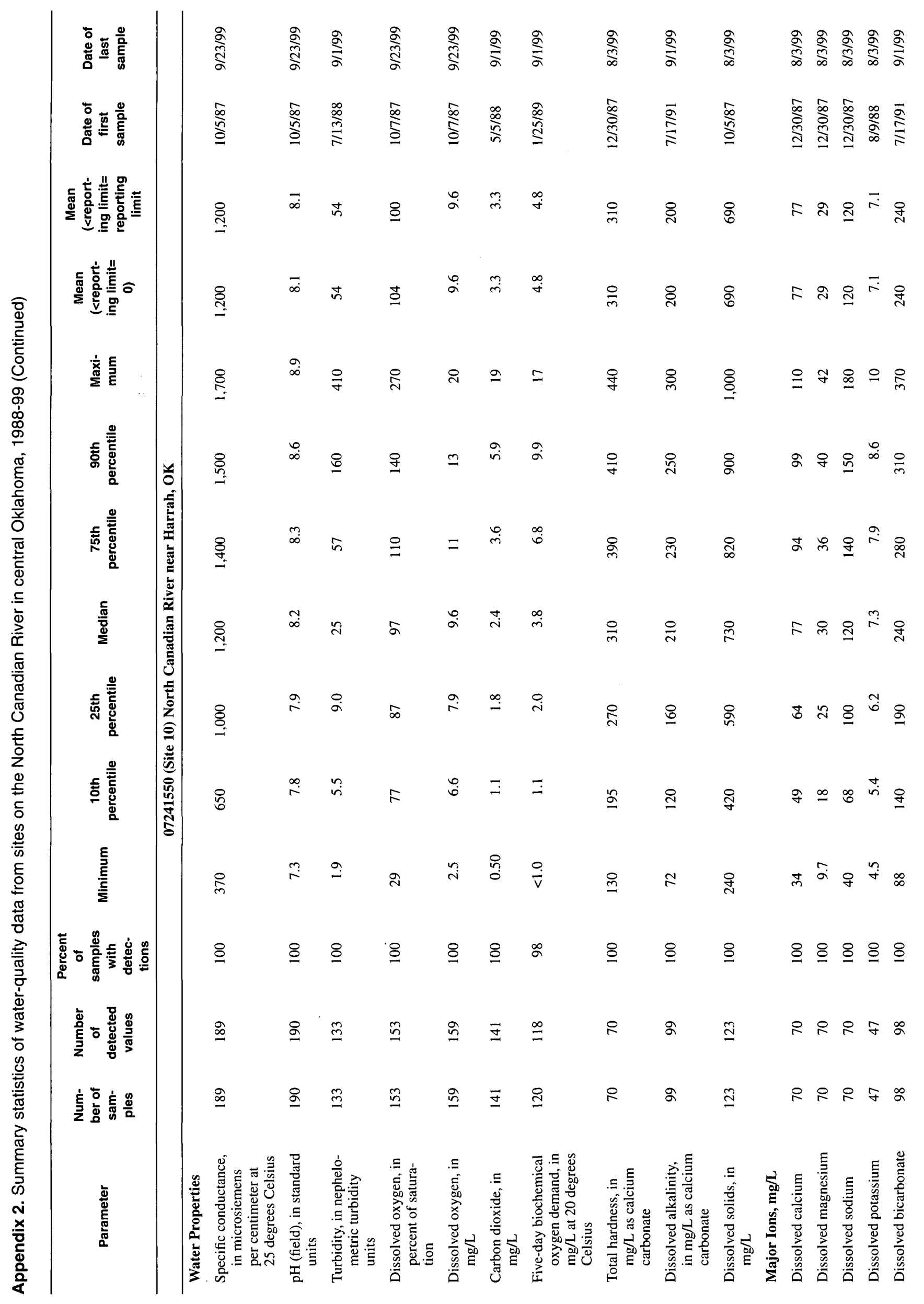




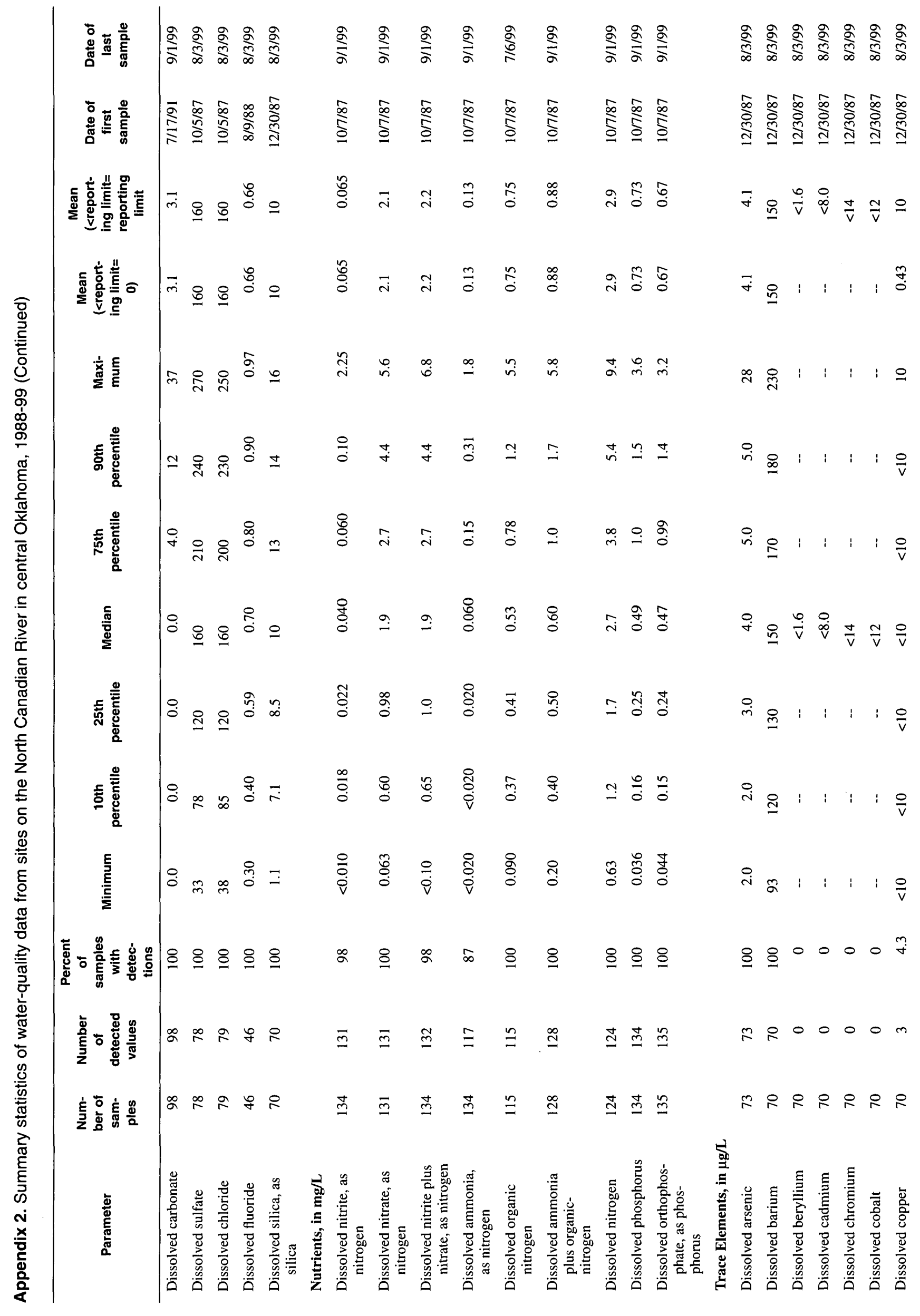




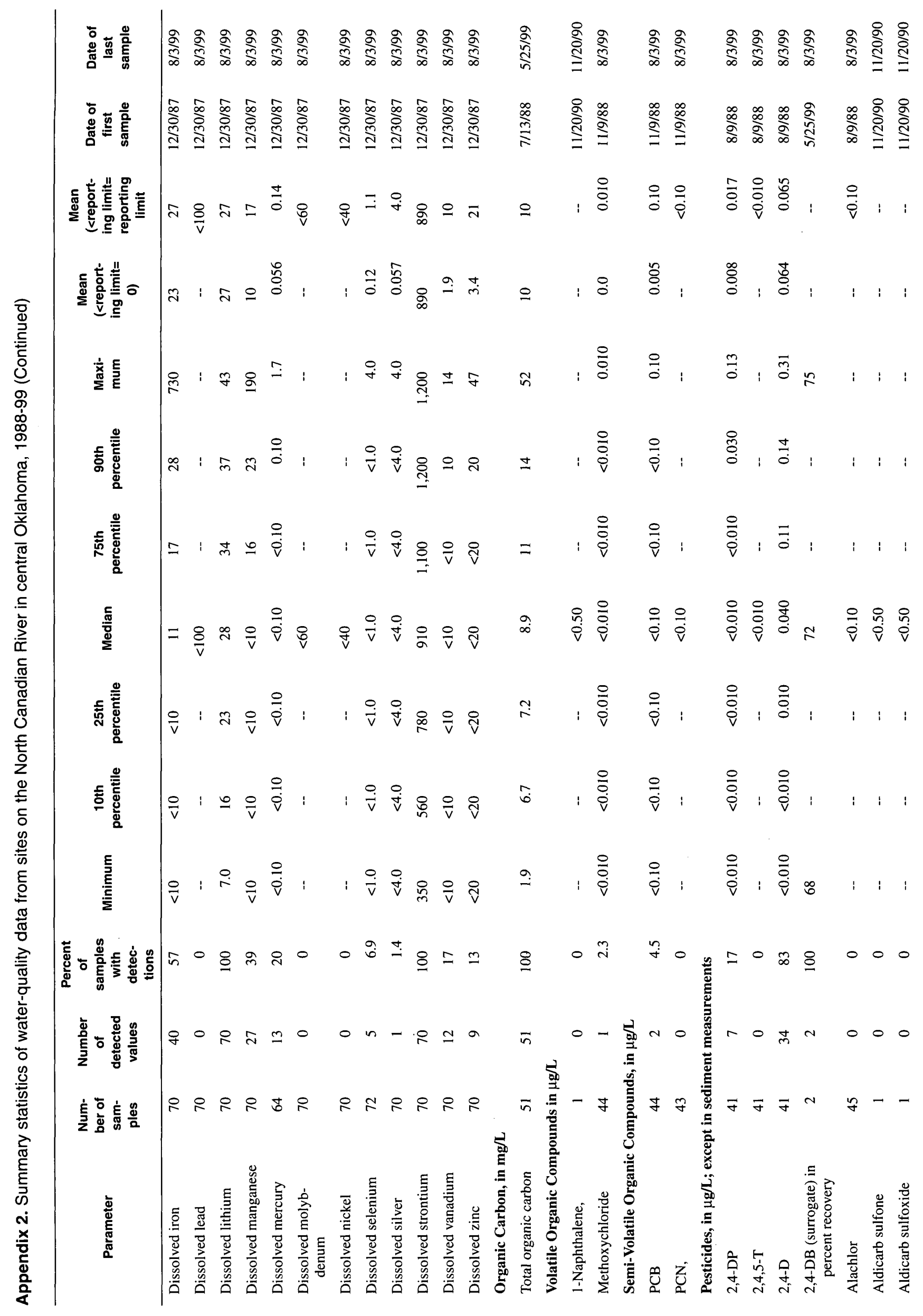




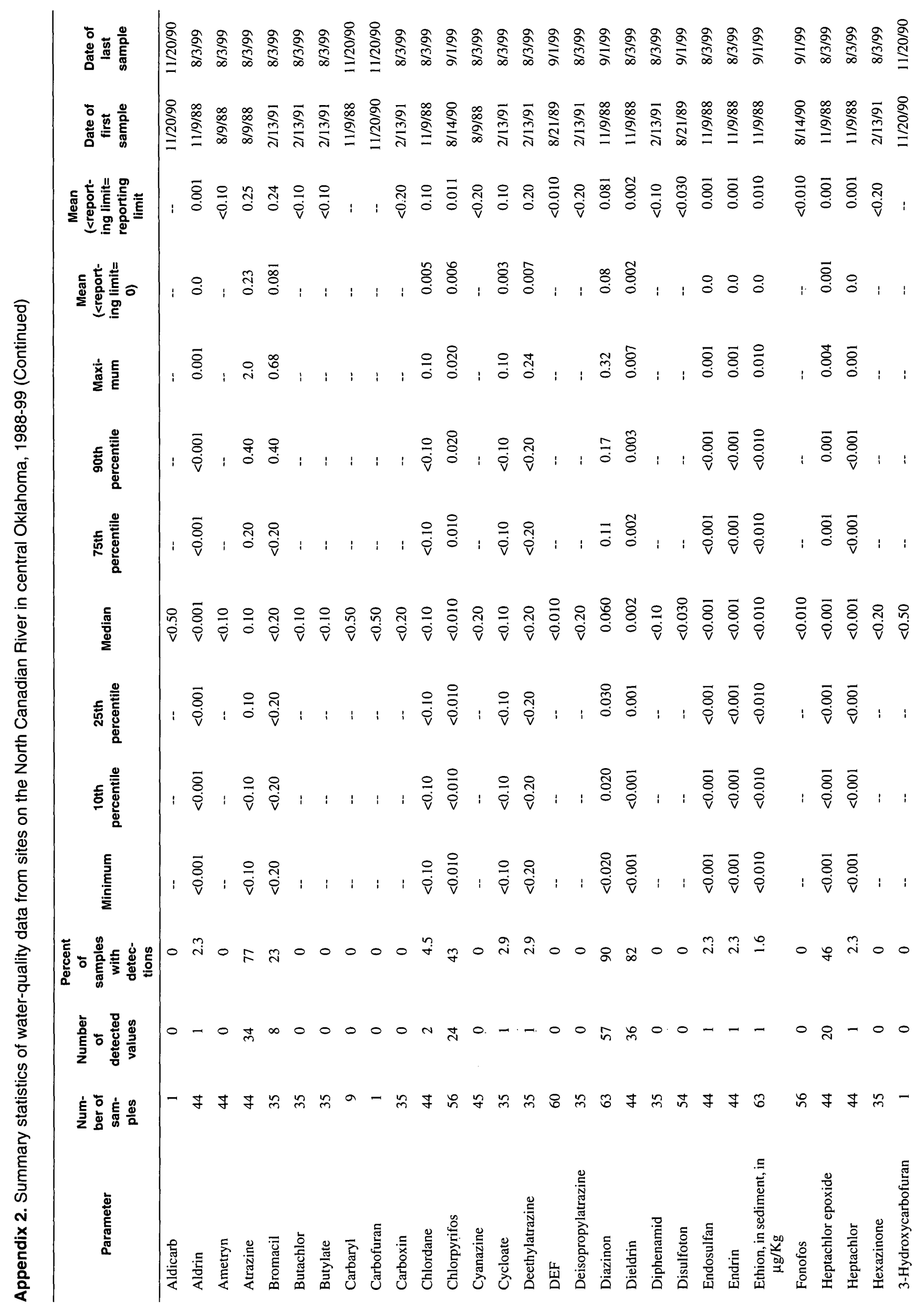




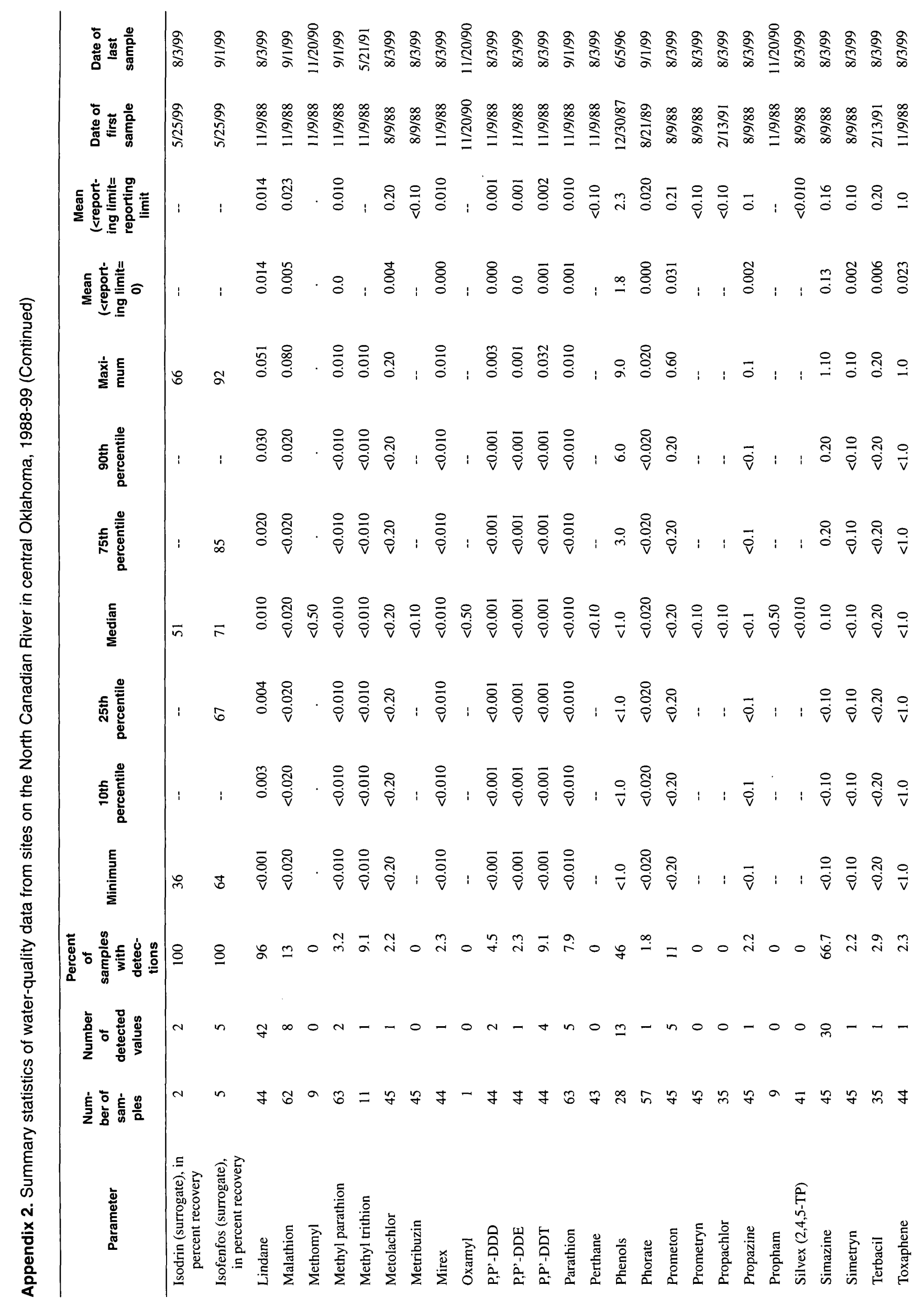




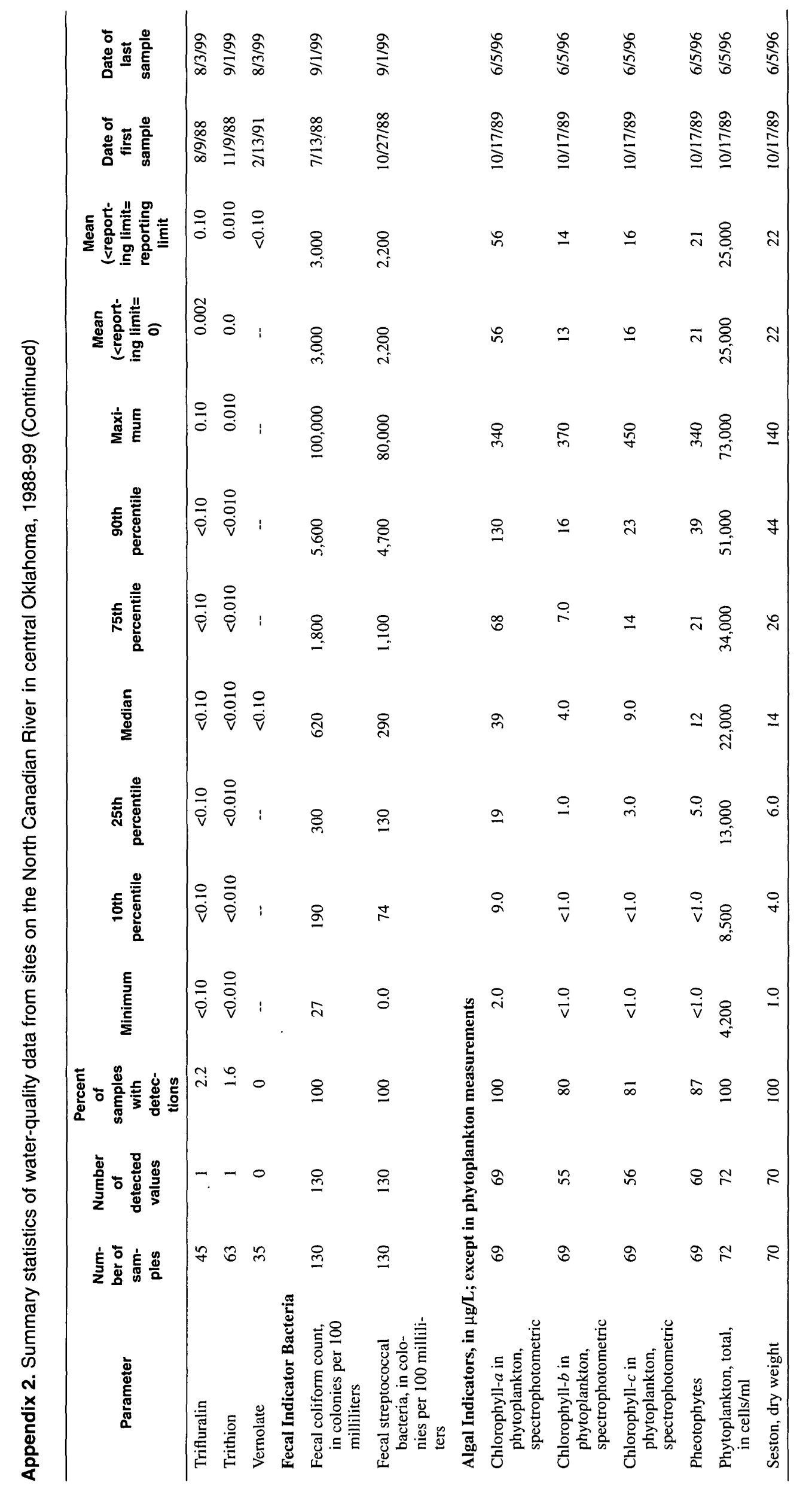




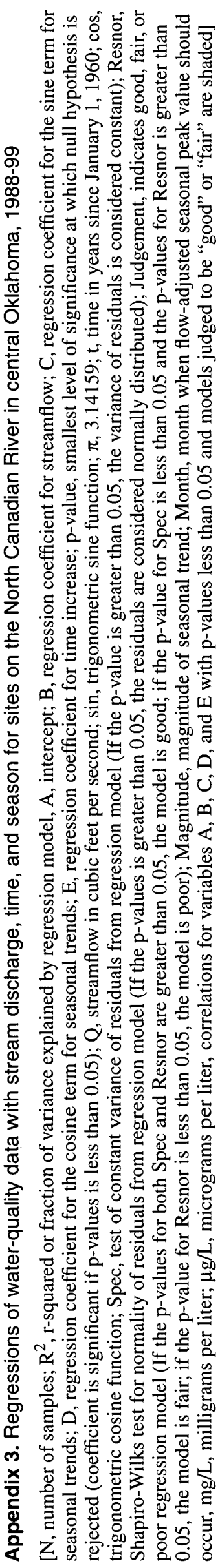

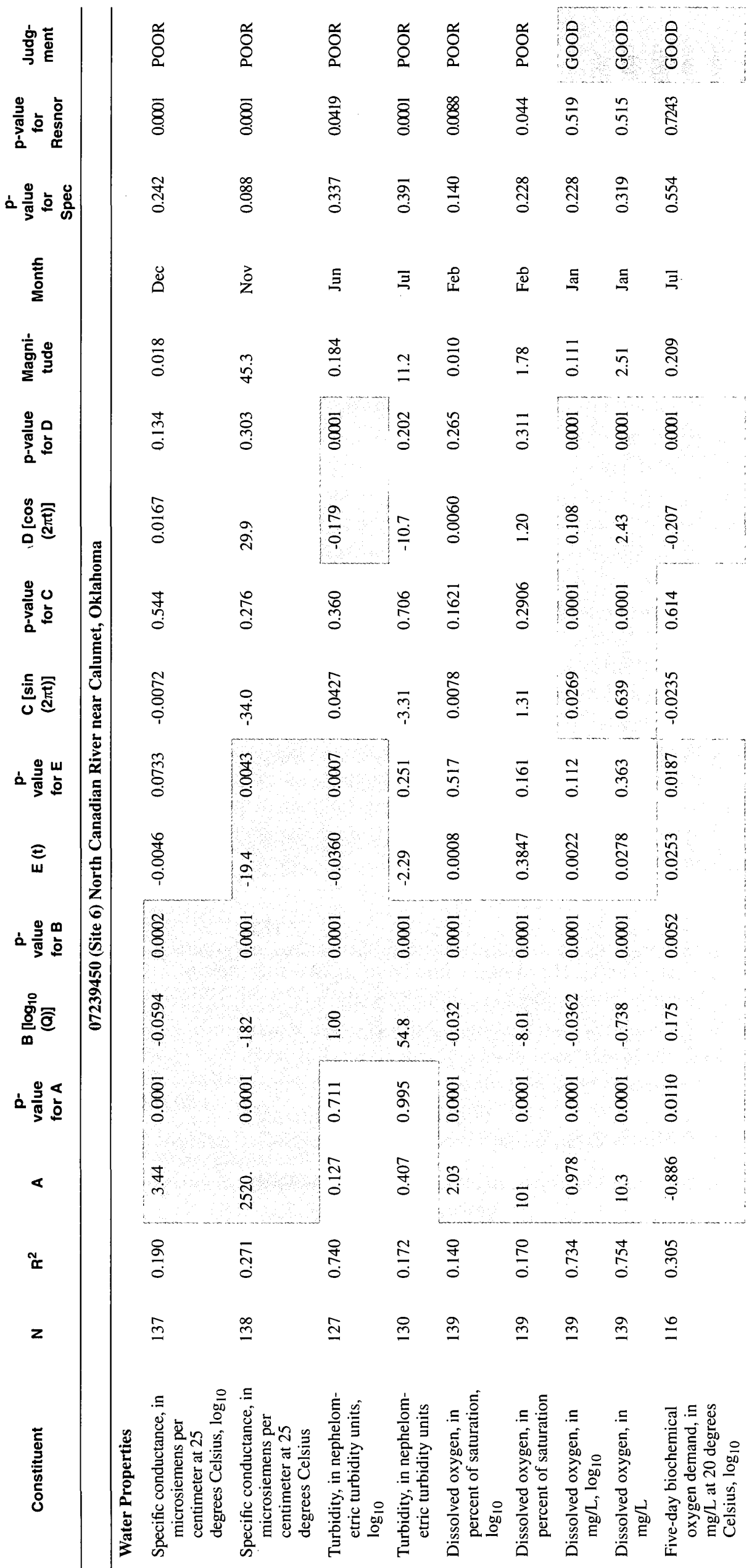




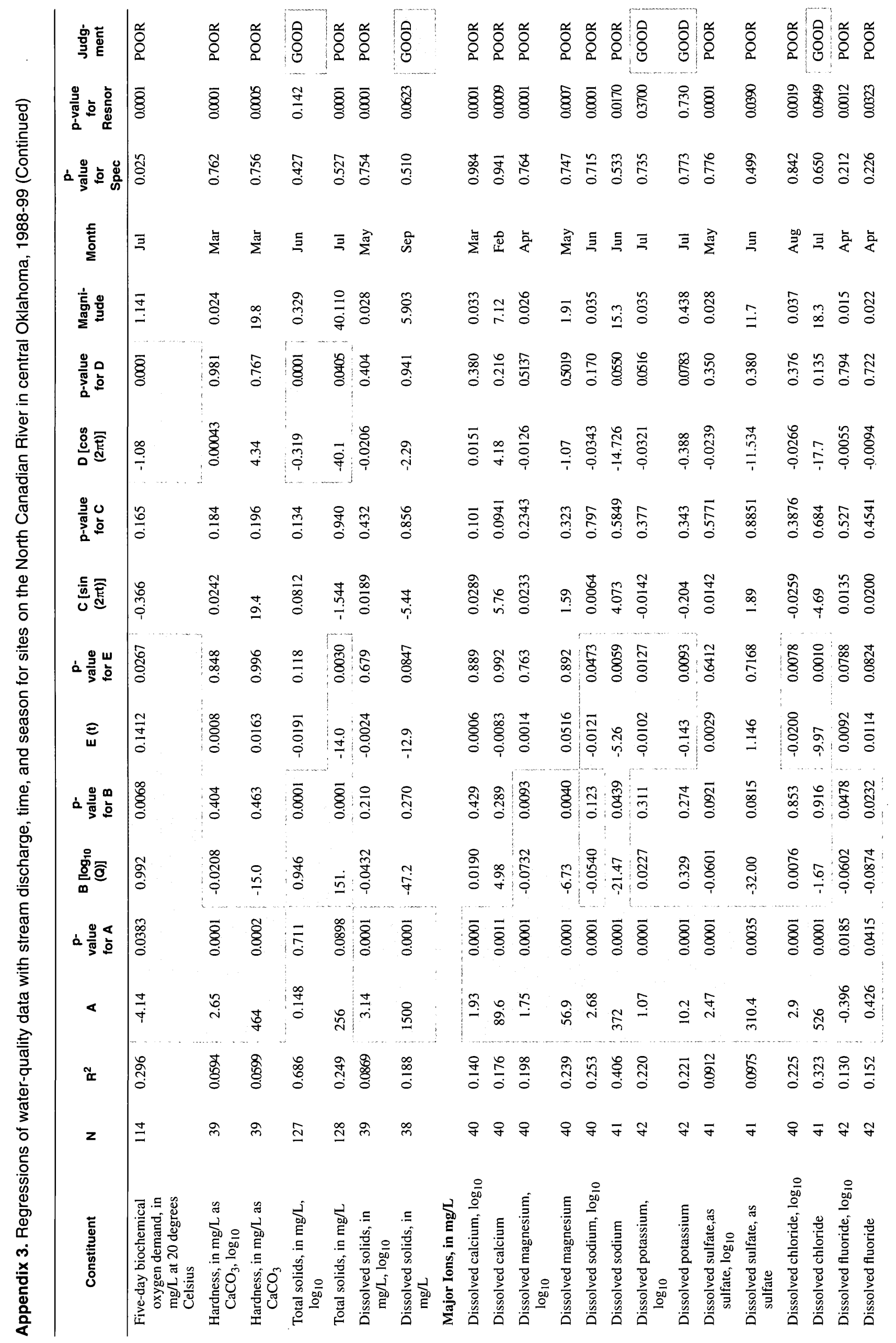




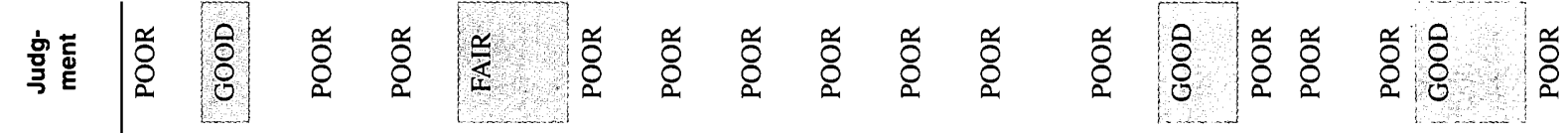

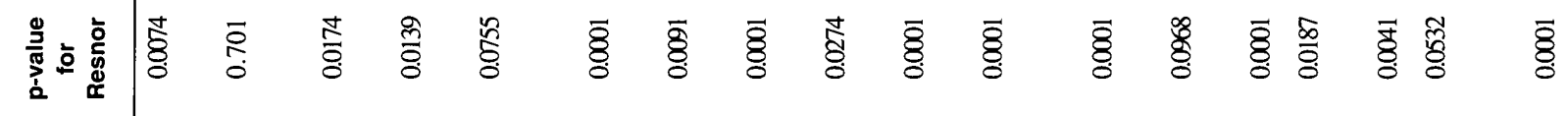

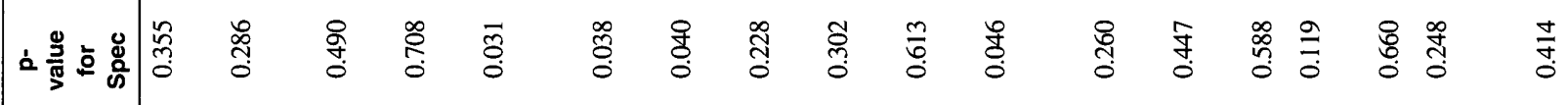

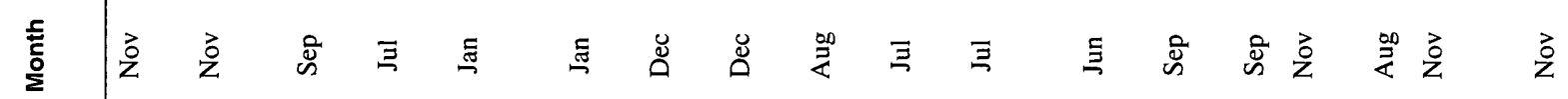
常

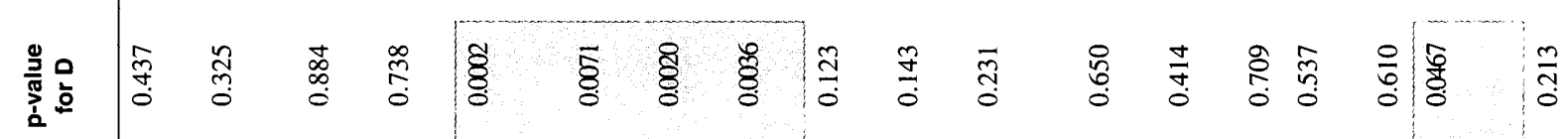
总零

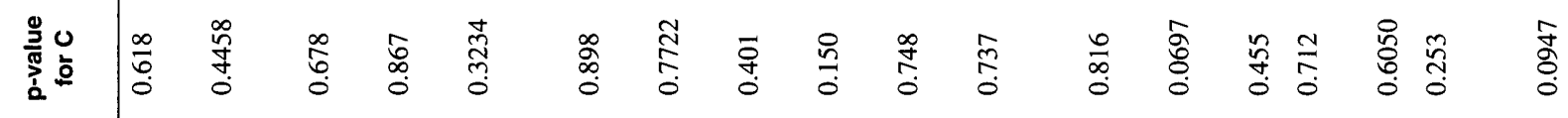

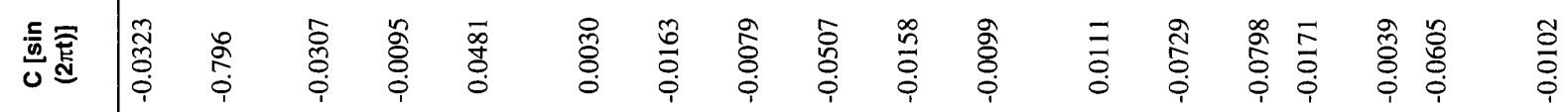
之总

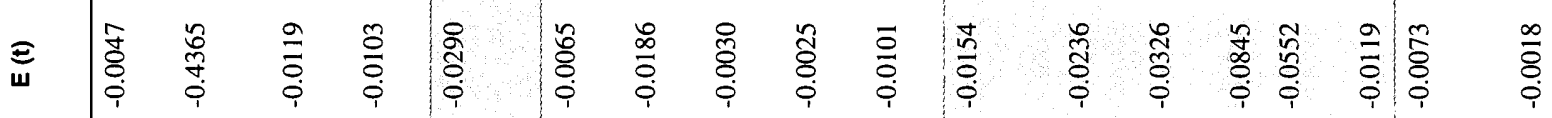

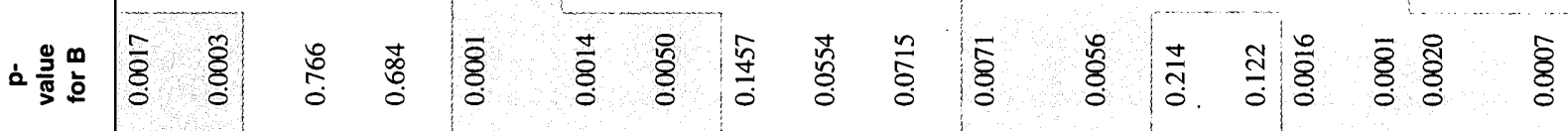

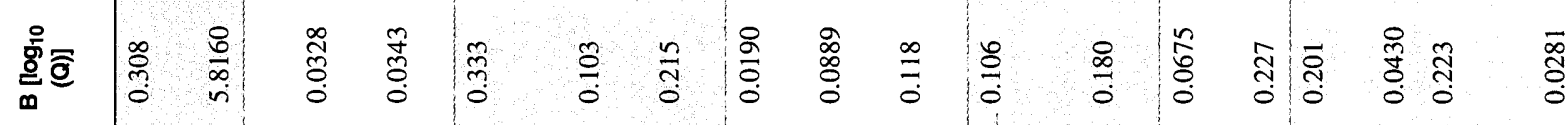

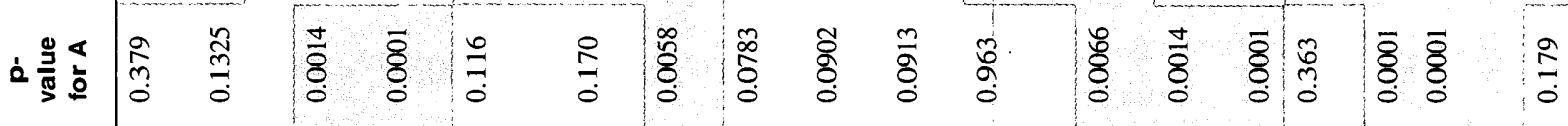

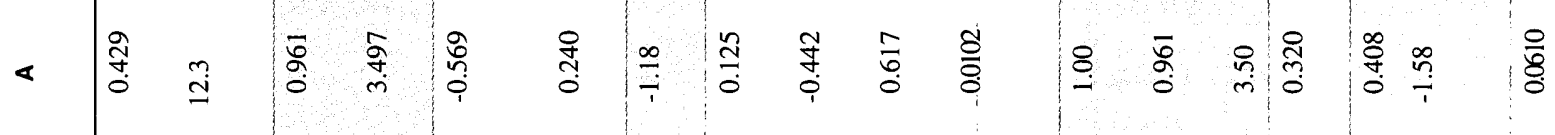

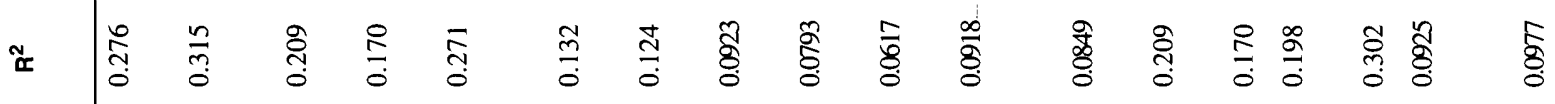

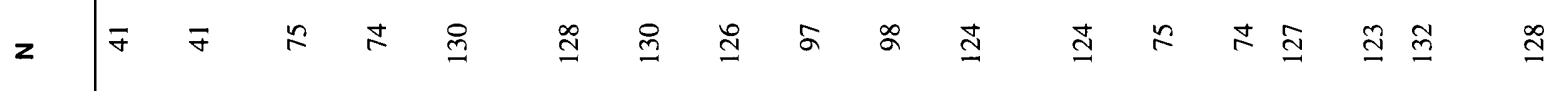

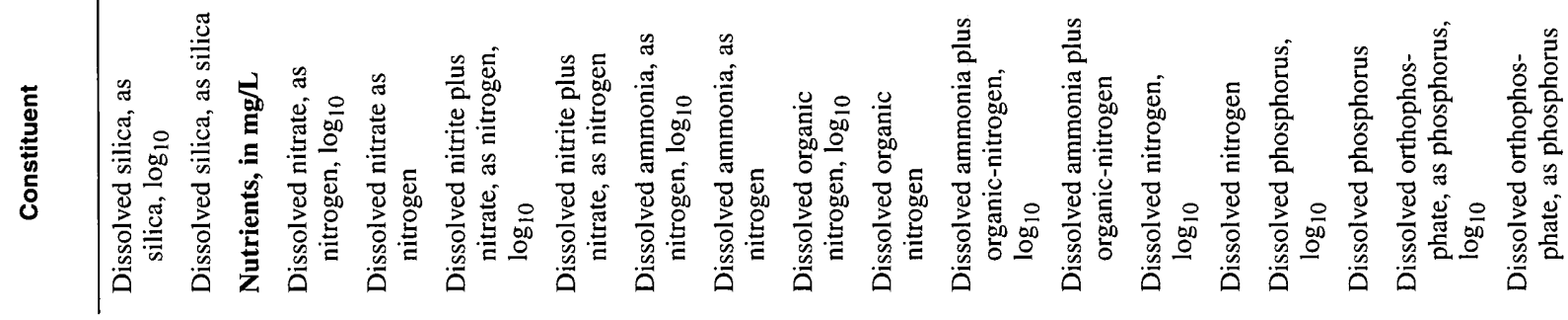




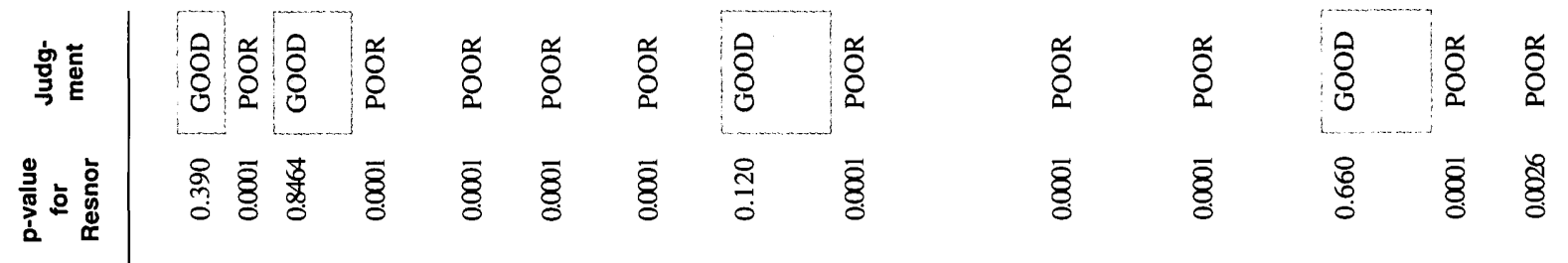

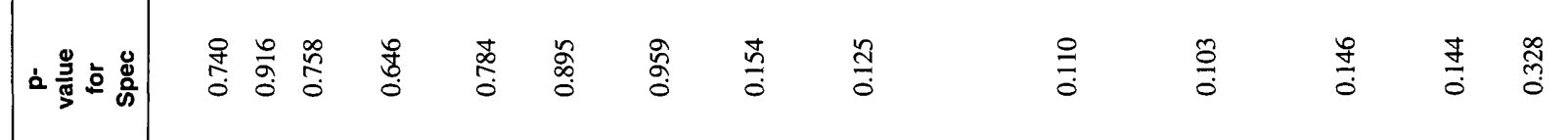

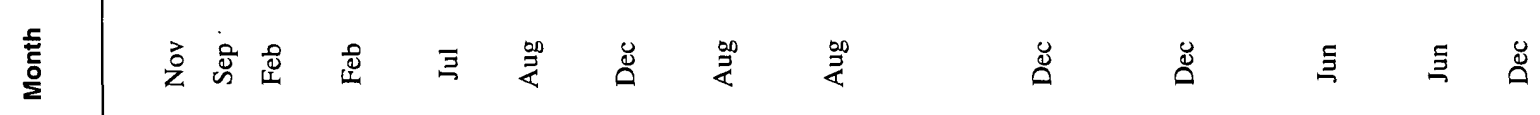

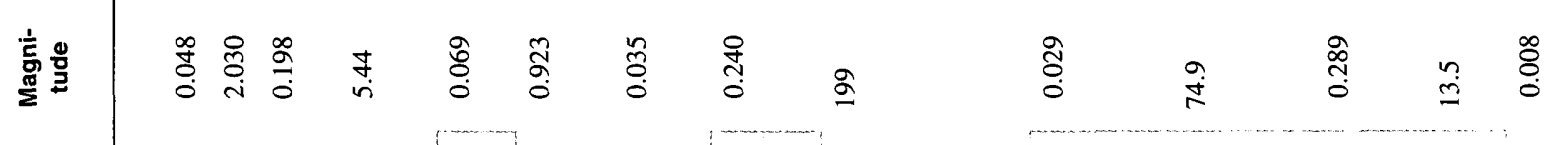

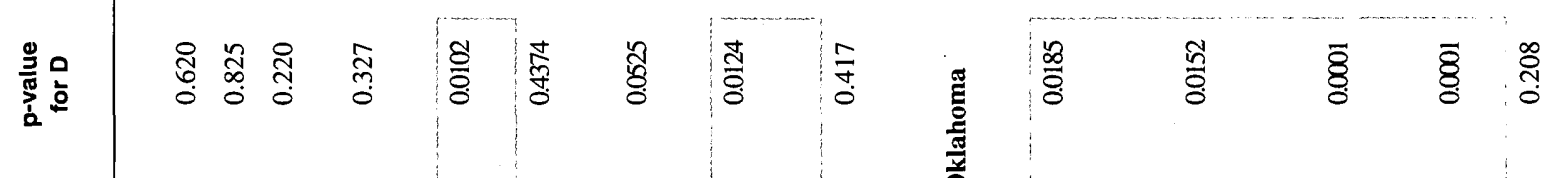

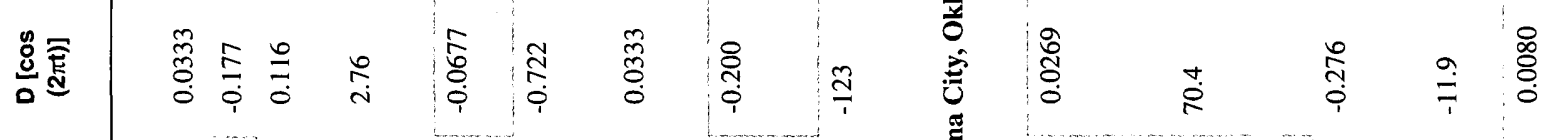

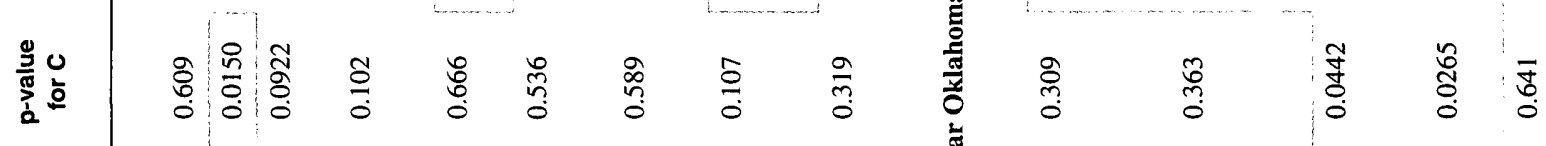

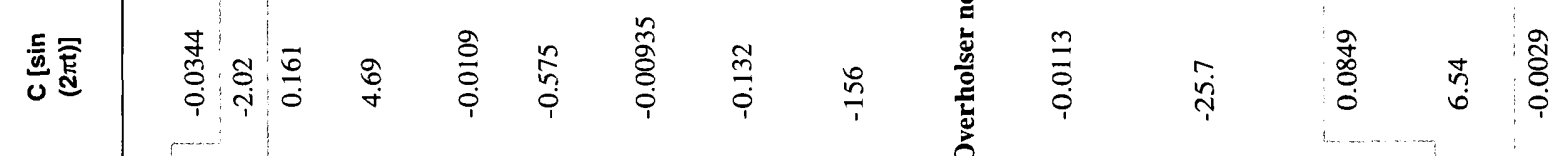

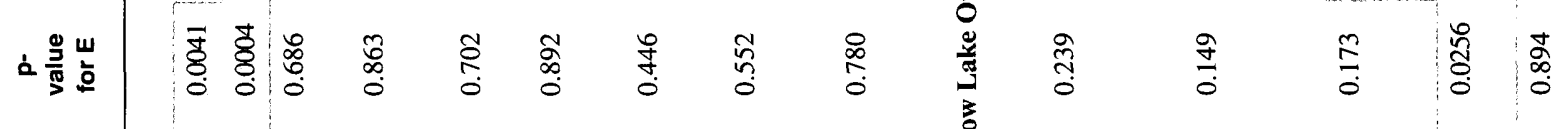

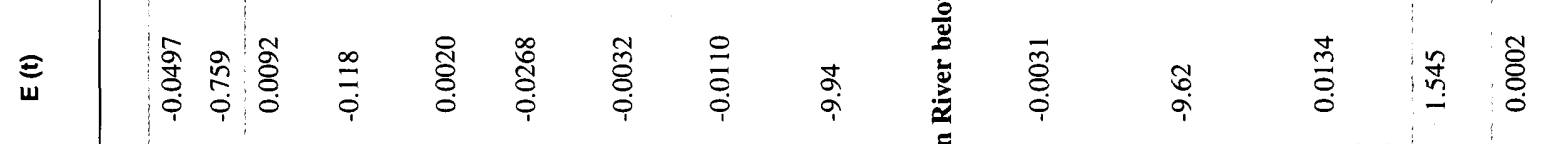

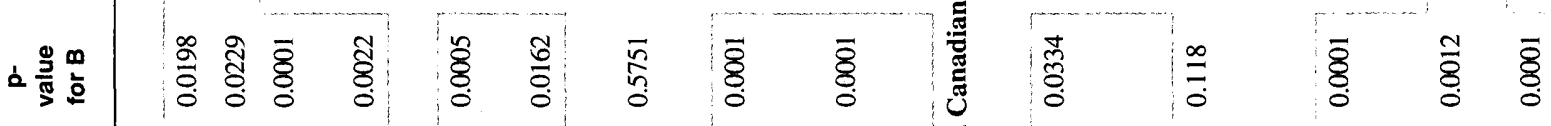

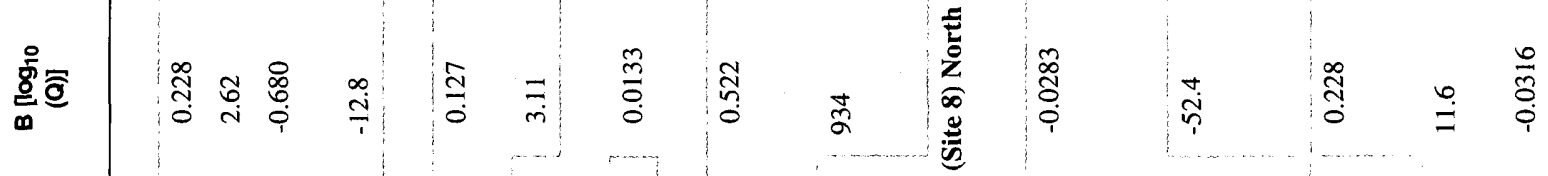

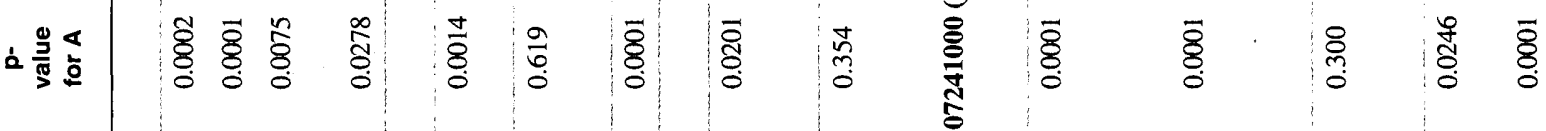

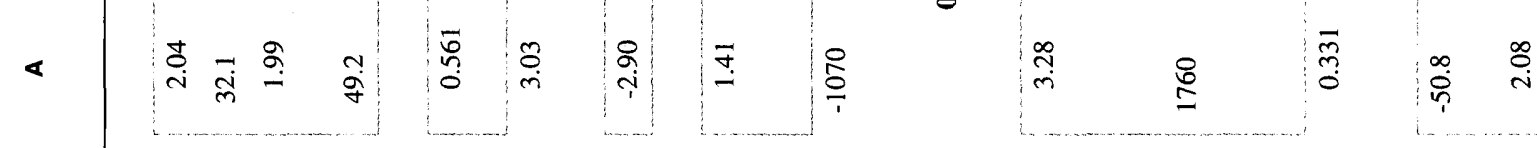

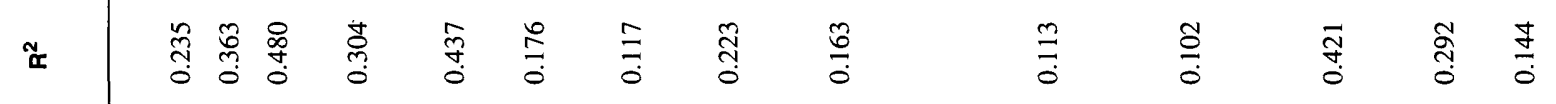

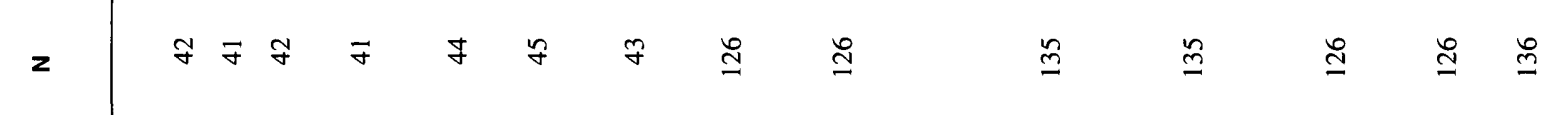

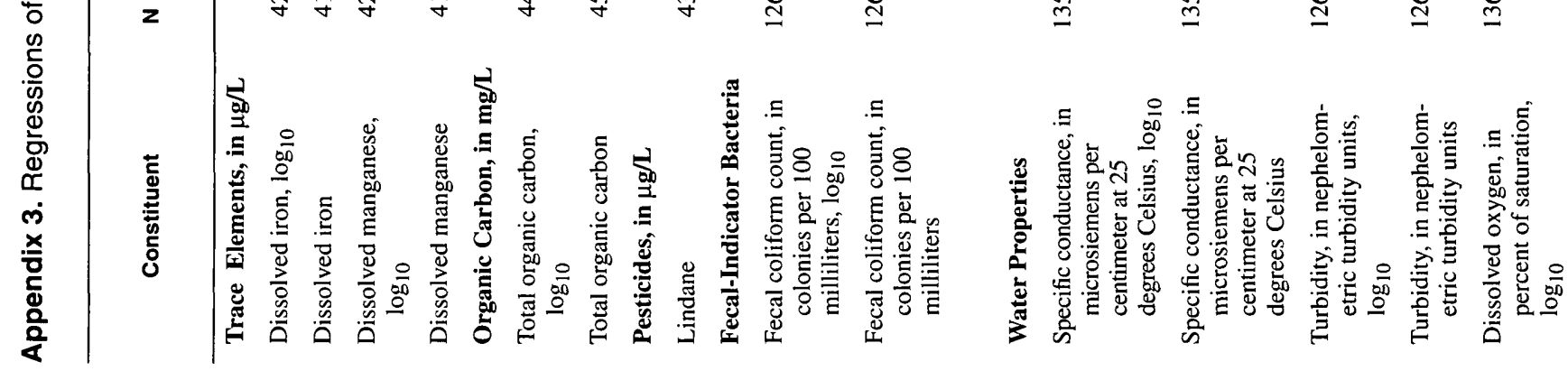




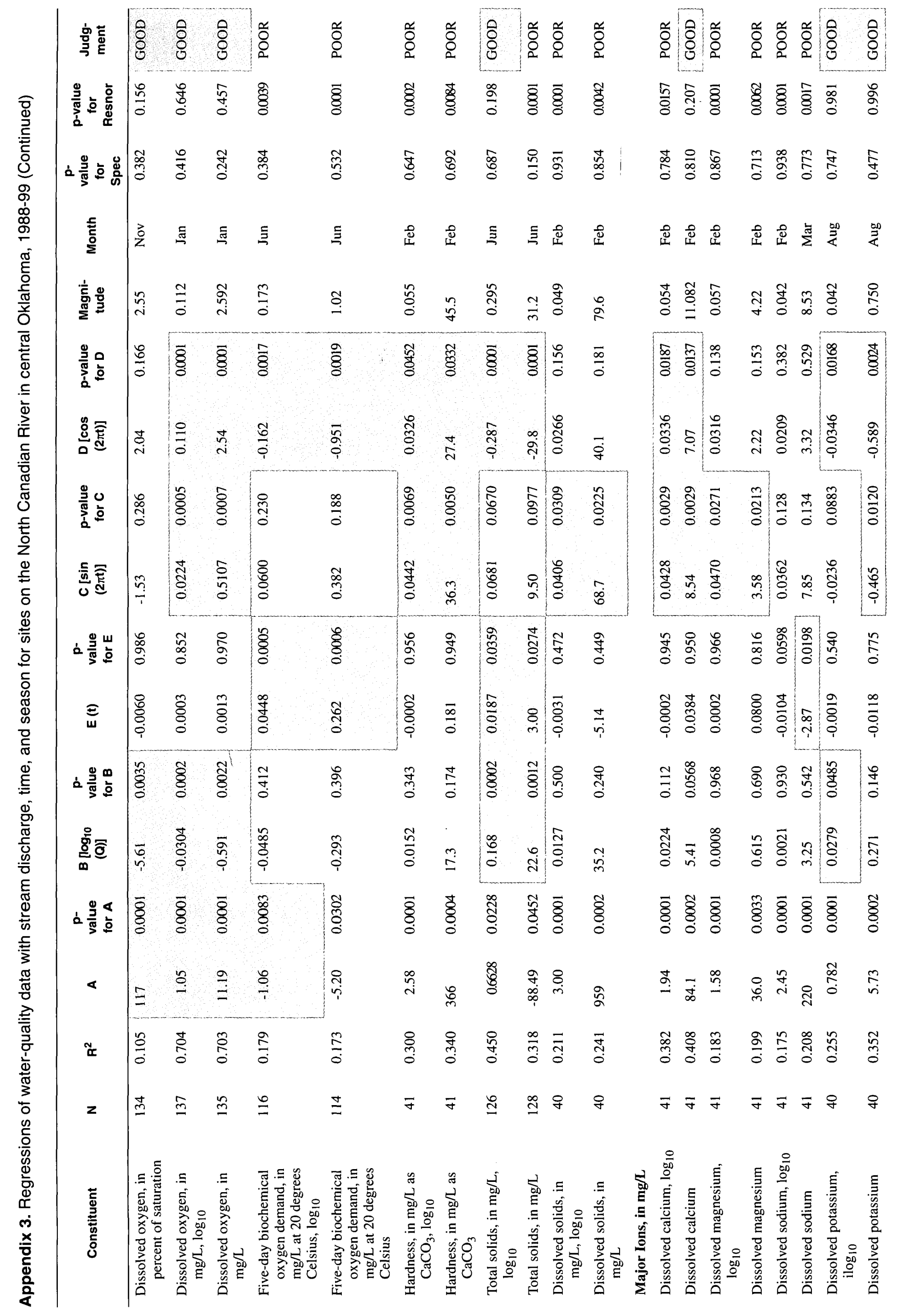




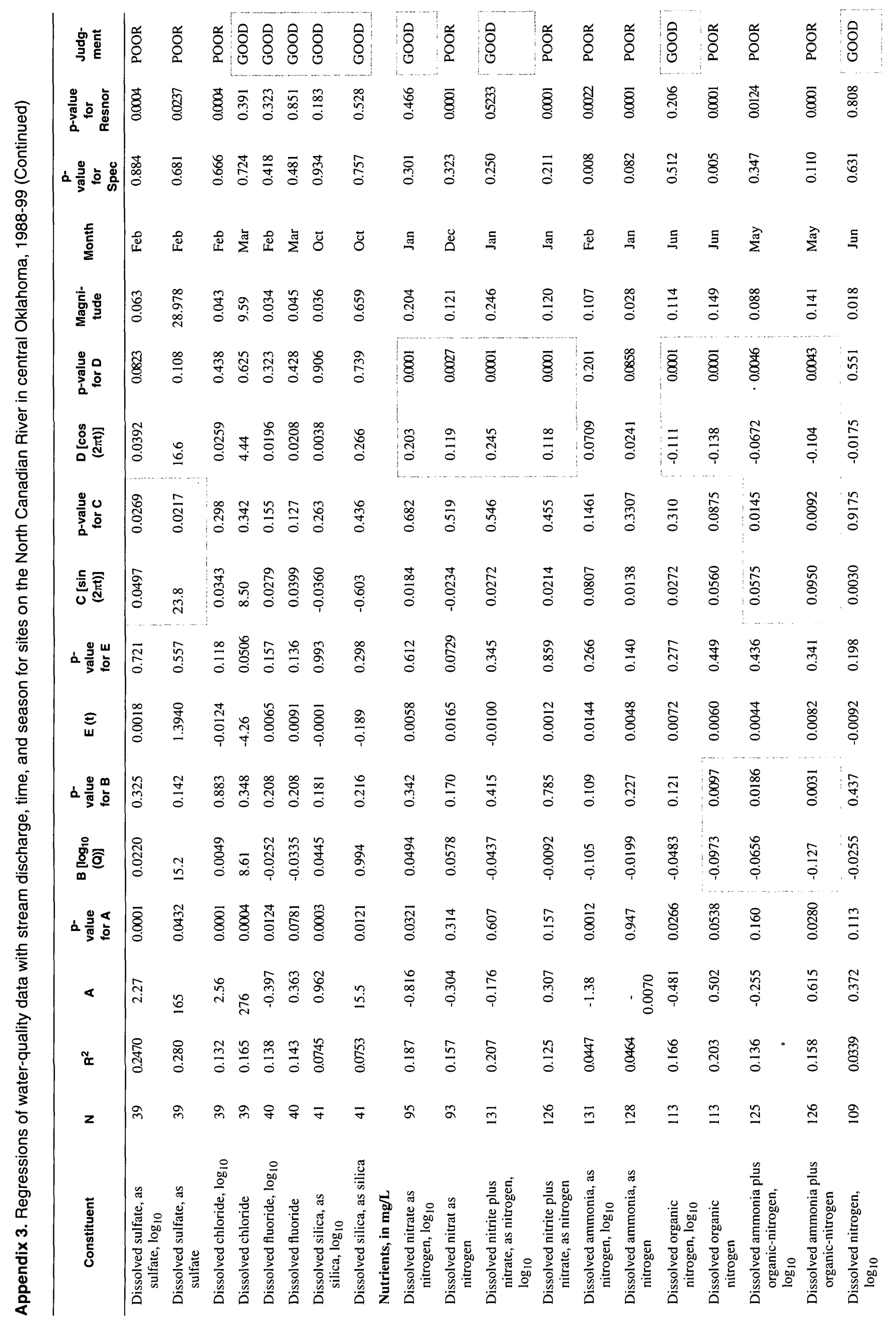




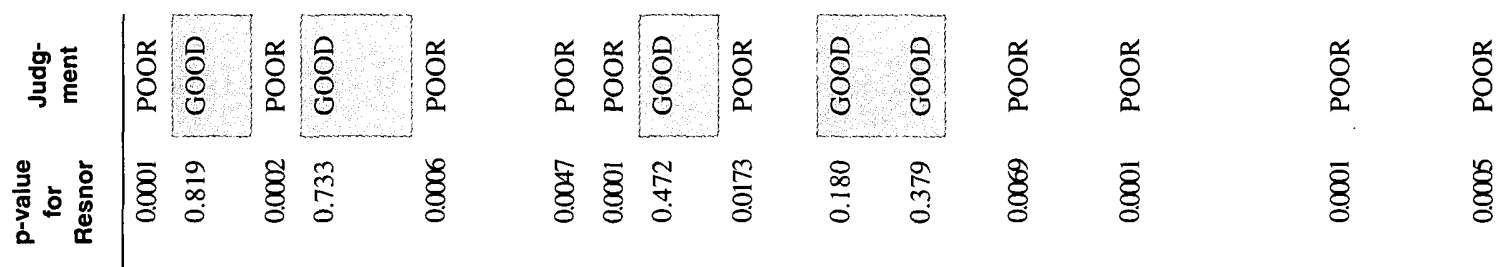

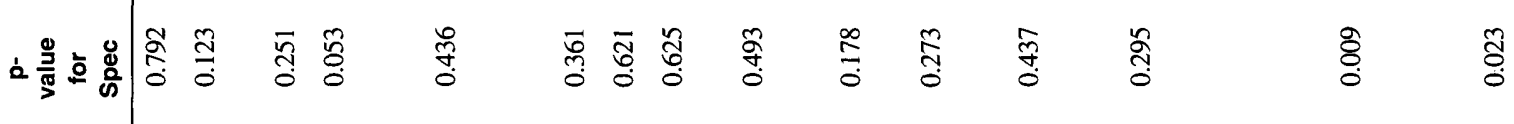

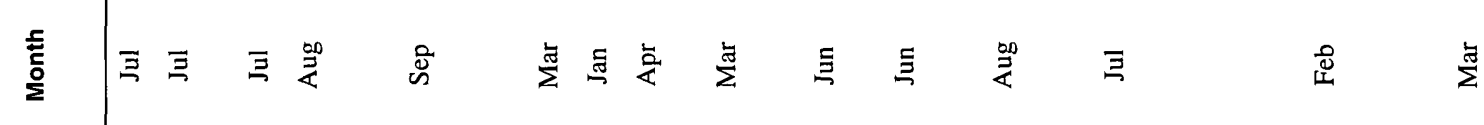

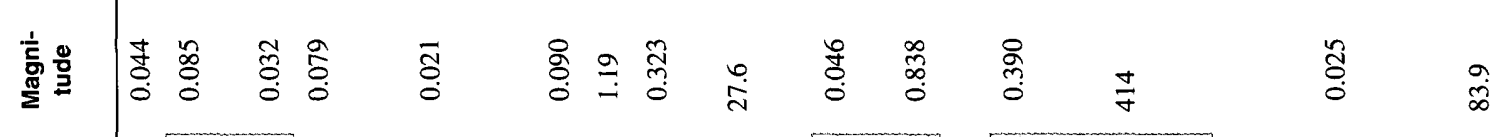

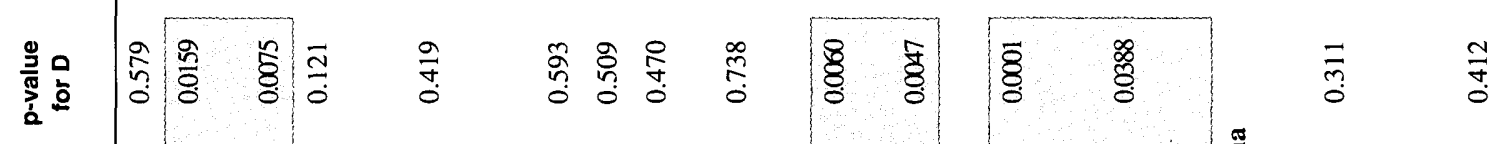
.

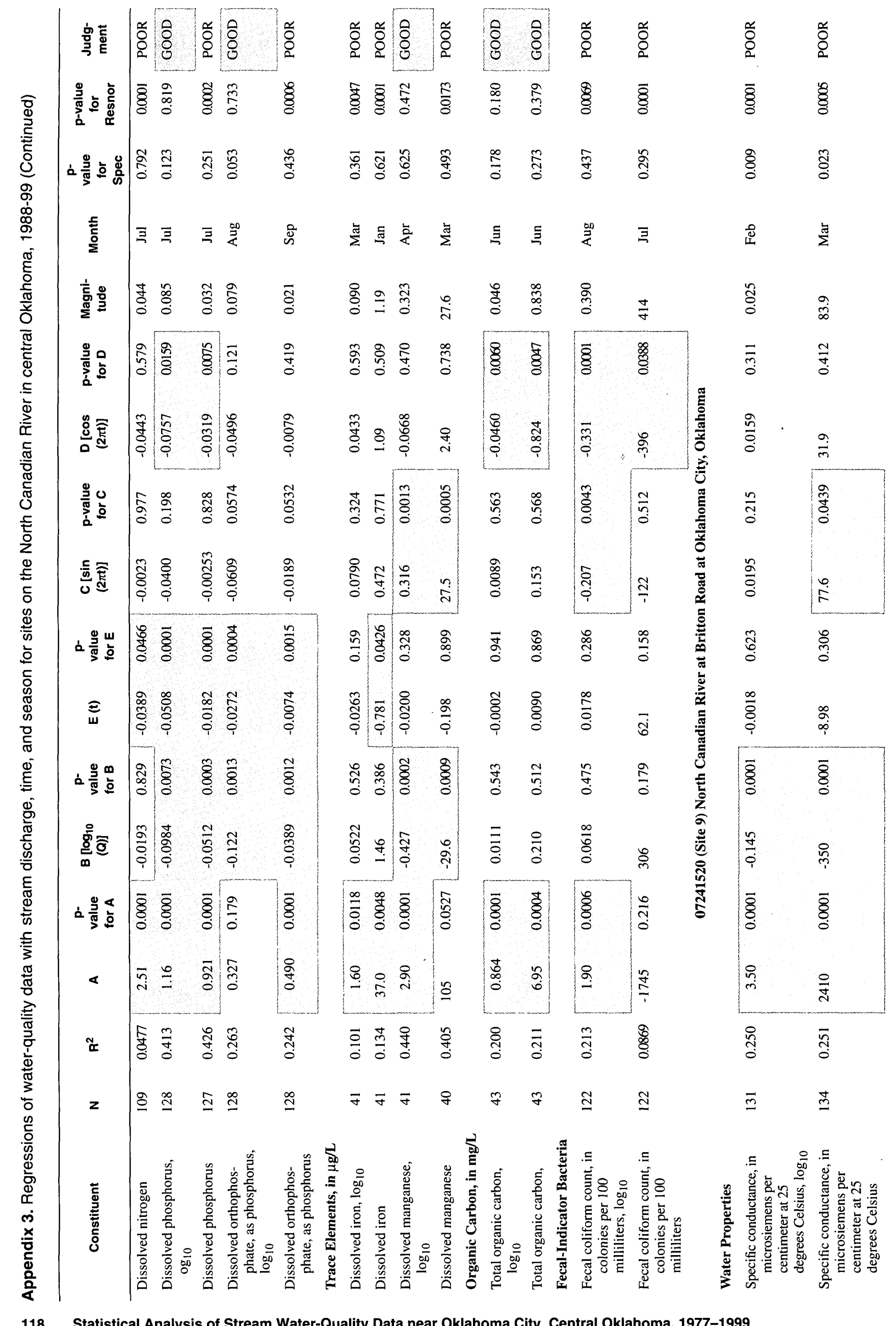


宇泀

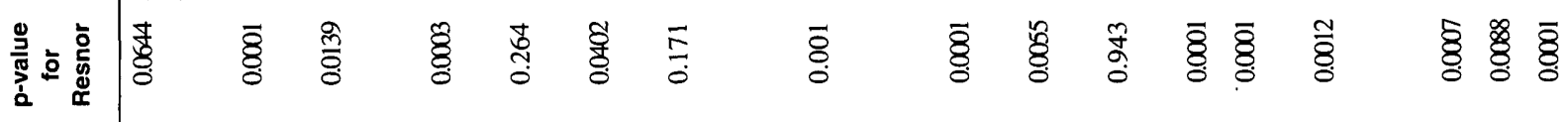

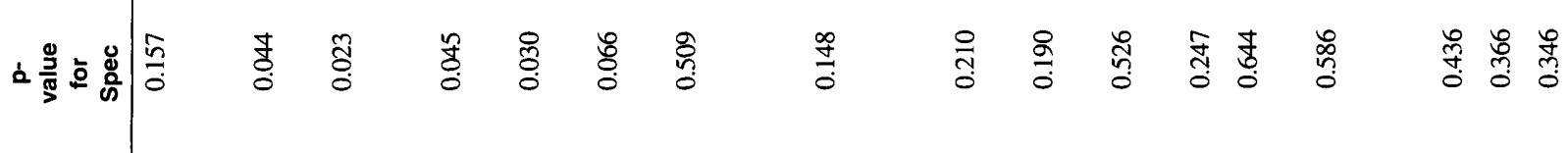

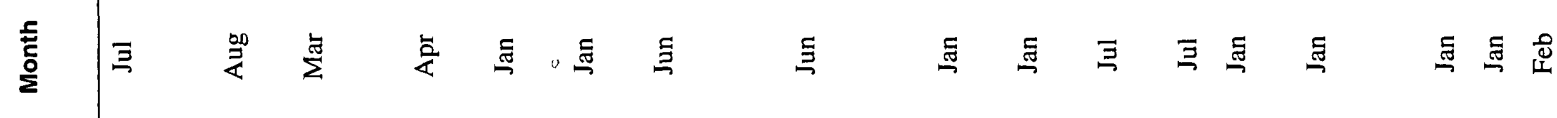

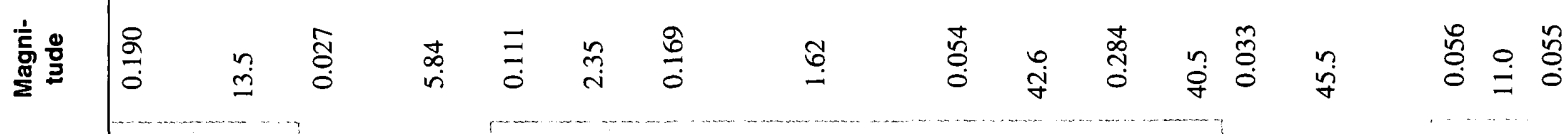

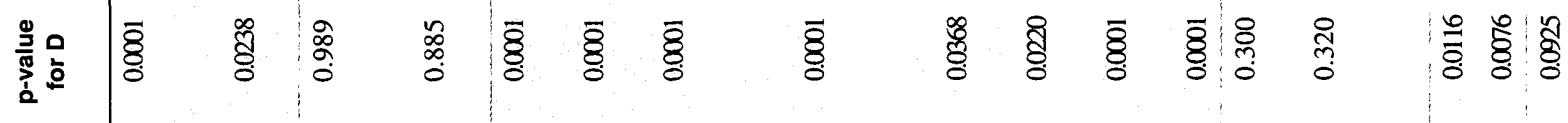

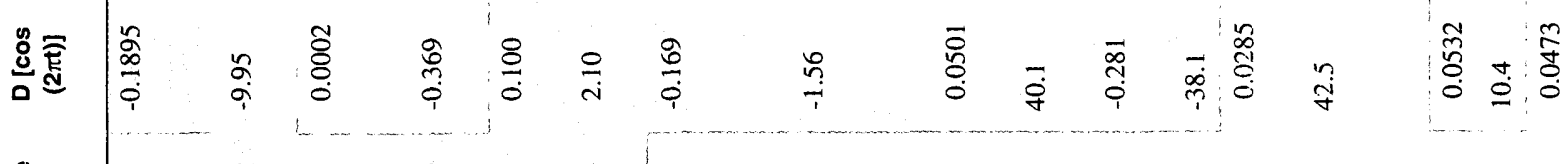

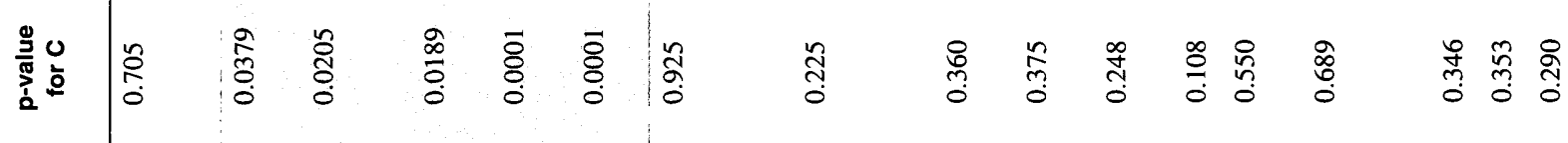

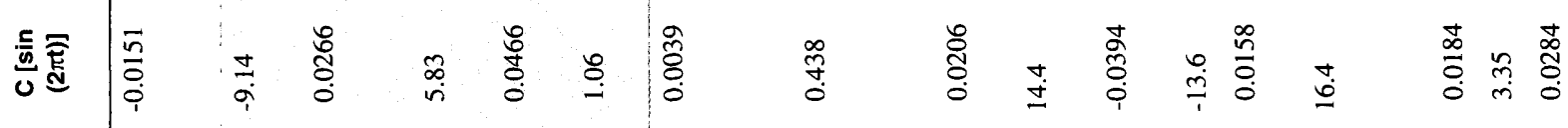

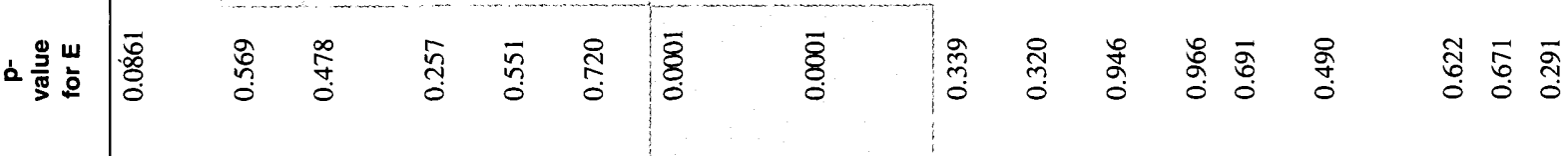

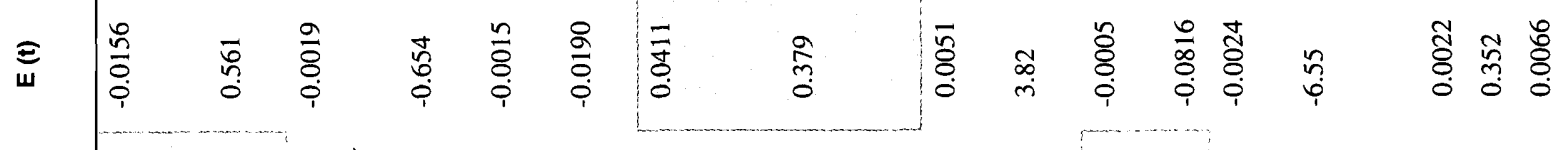

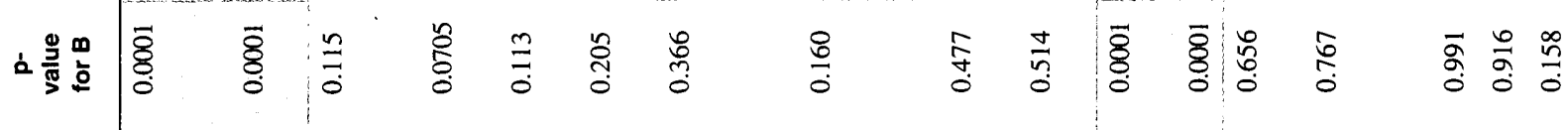

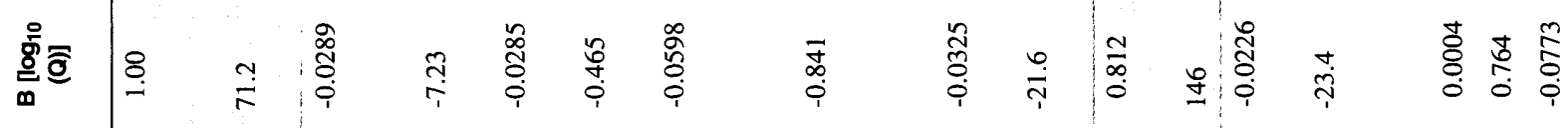

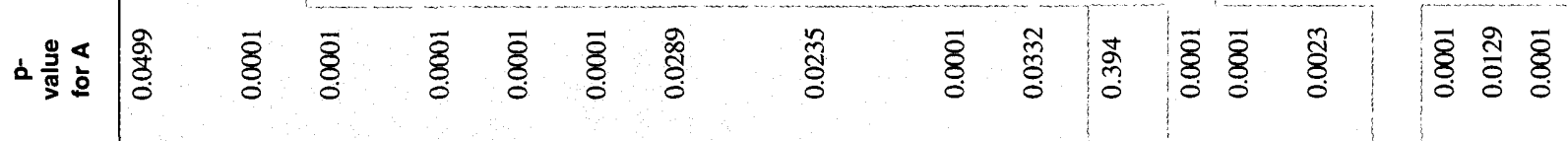

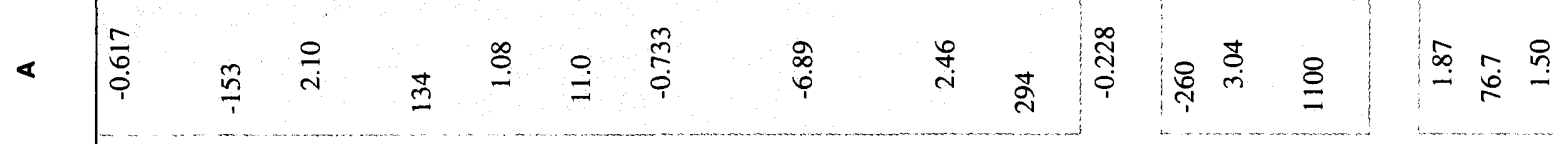

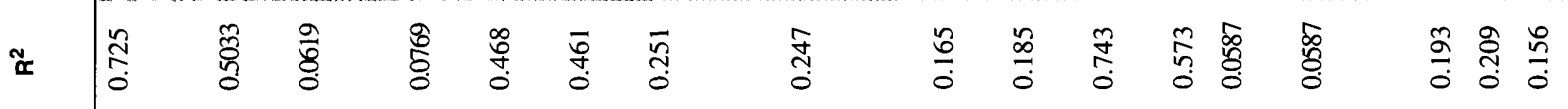

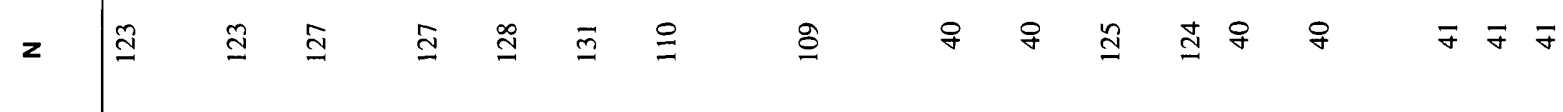

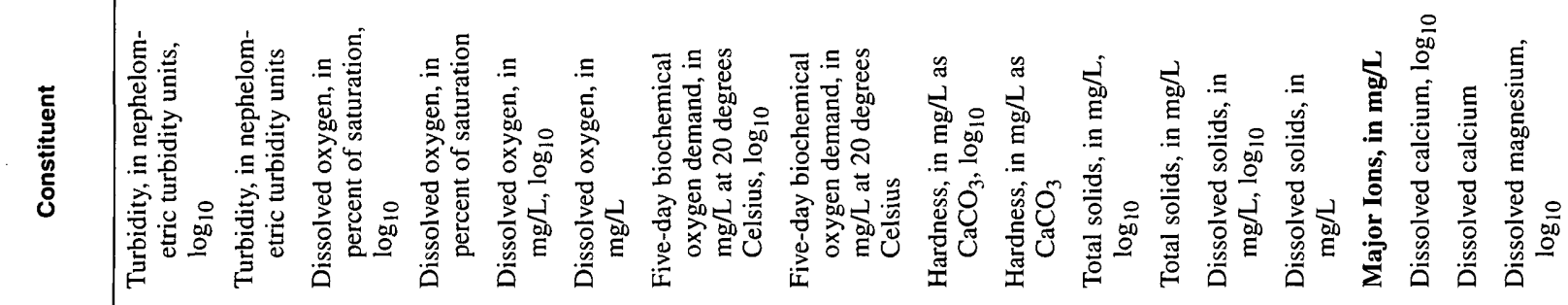




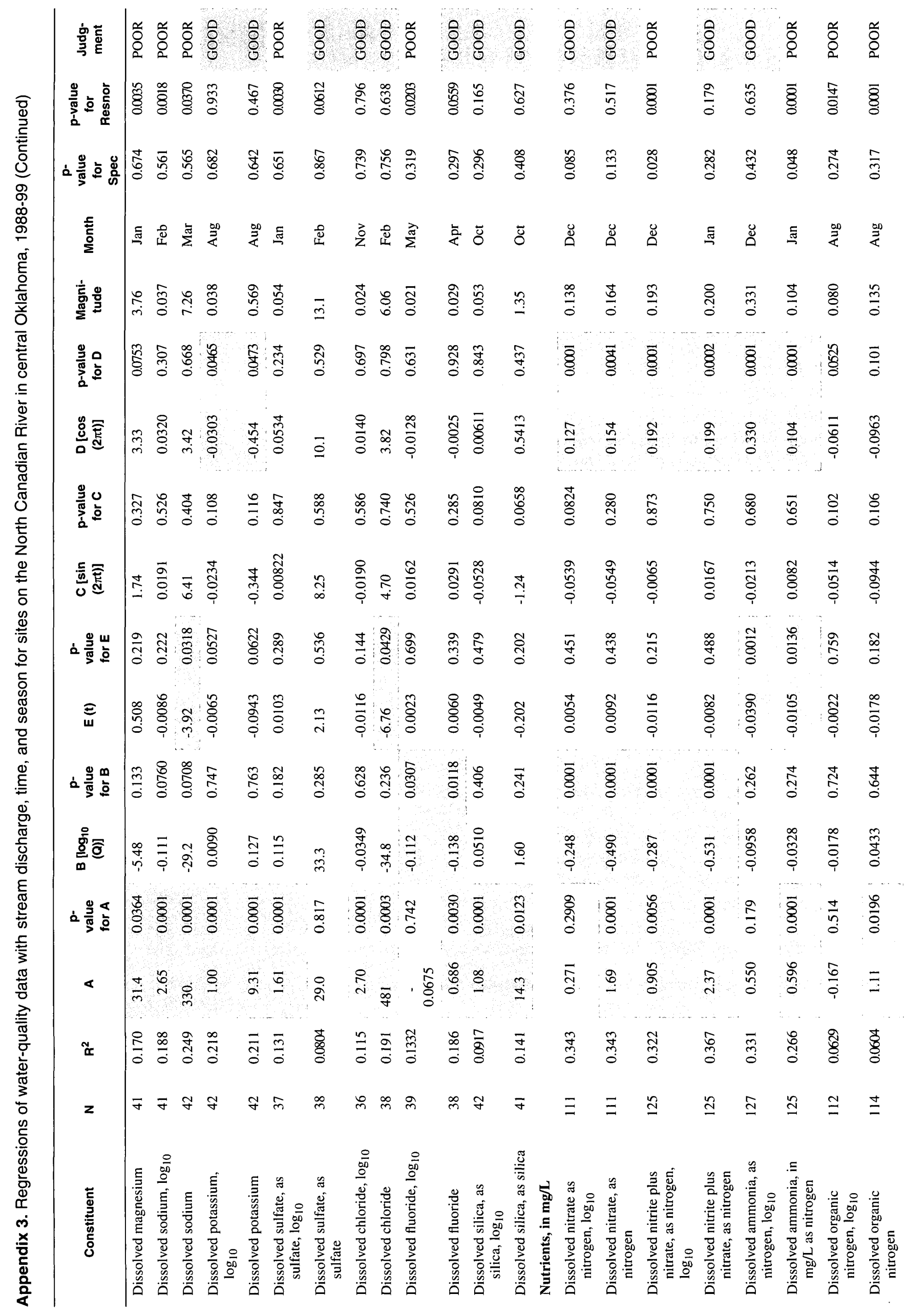




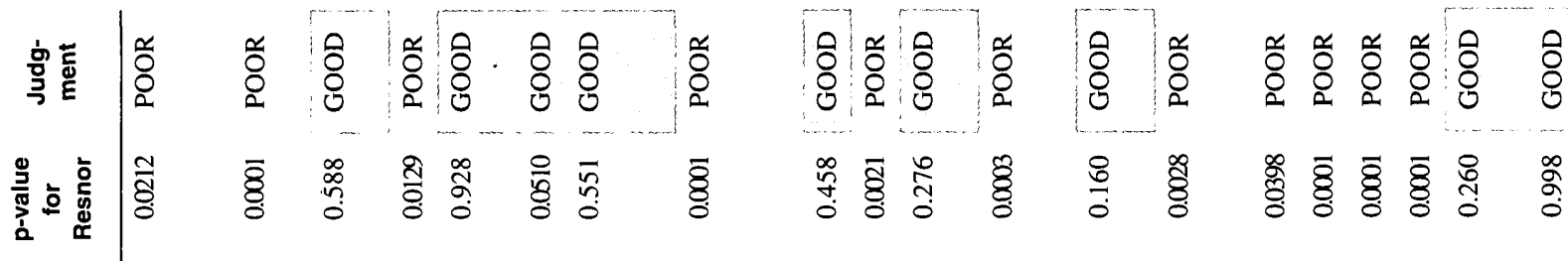




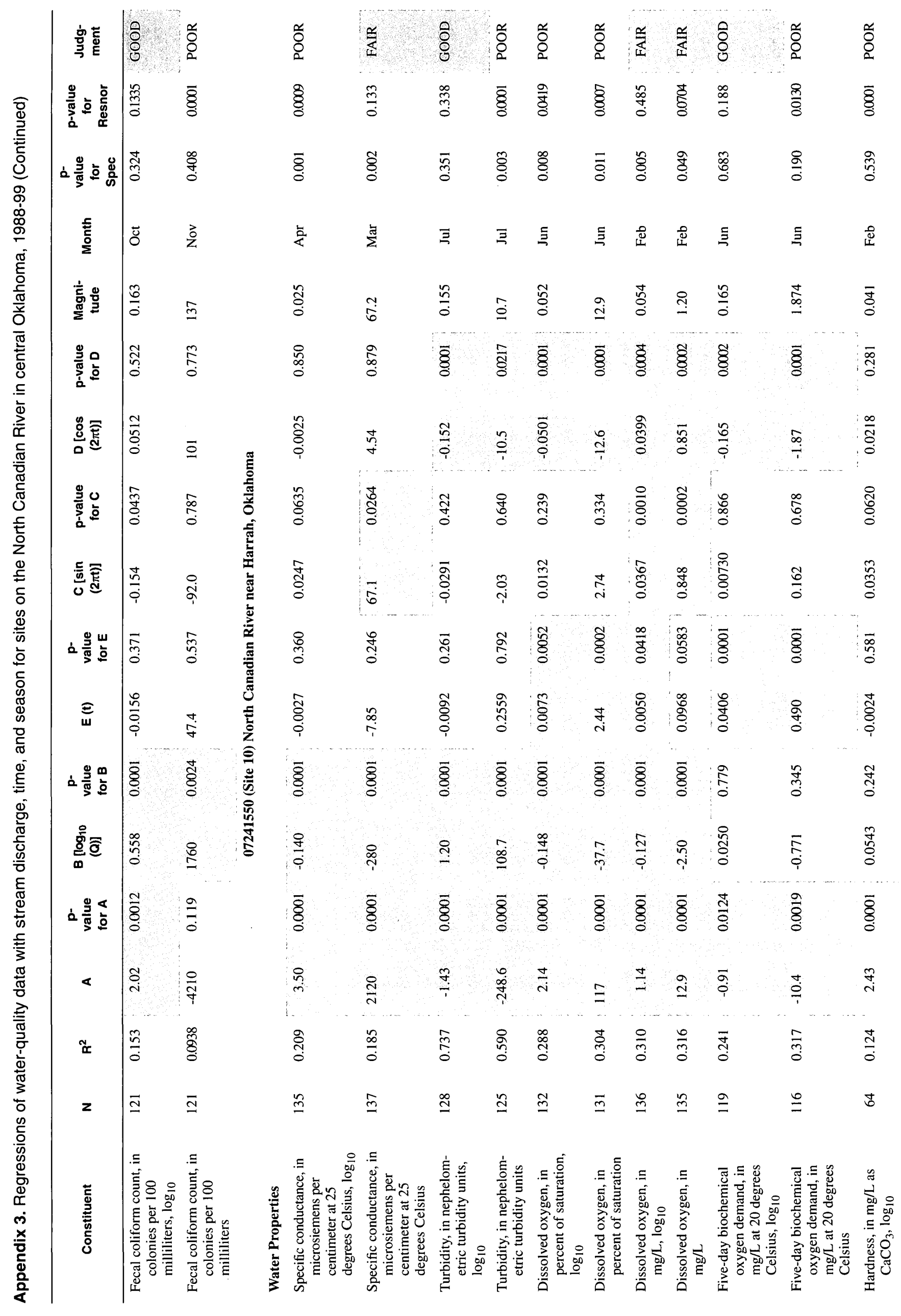




\section{$\widehat{0}$
0
$0 \bar{c}$
$\overline{0}$
0
0
0
0
0
0}

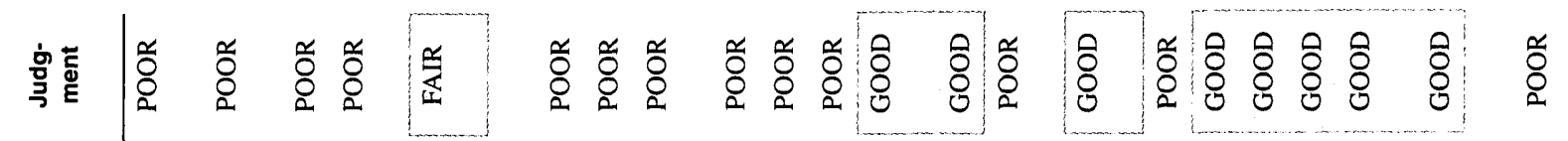

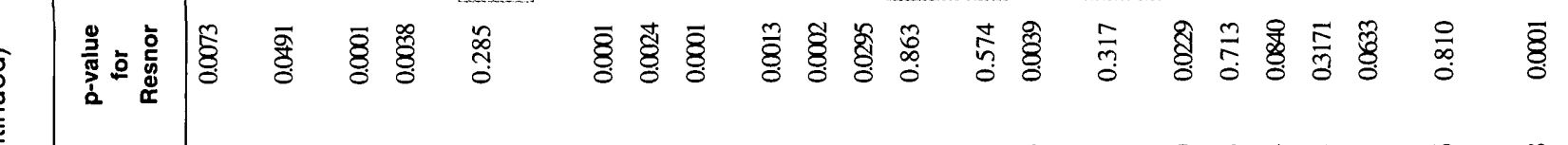

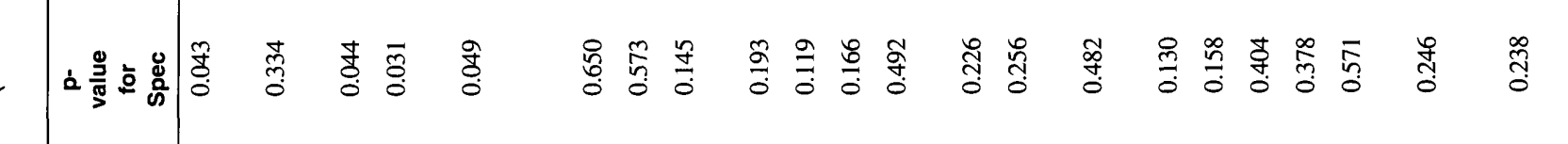

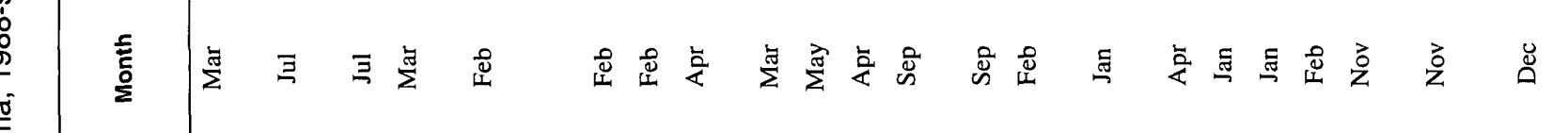

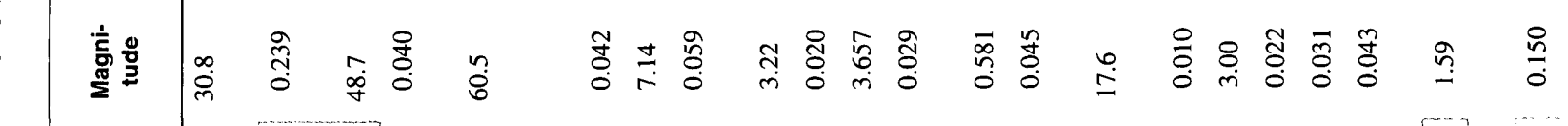

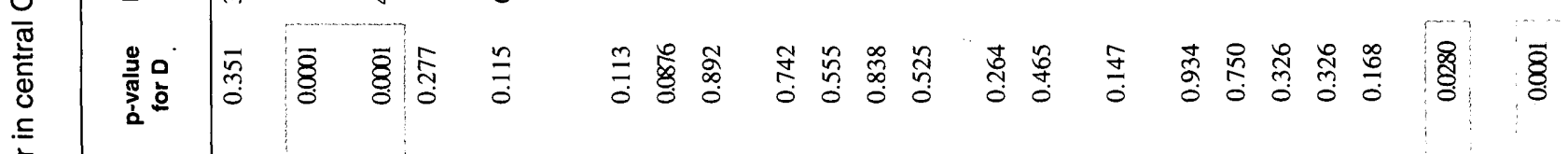

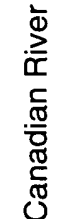

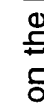

ปั

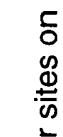$$
\text { 跣 }
$$

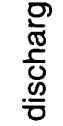

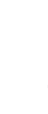

总蛋

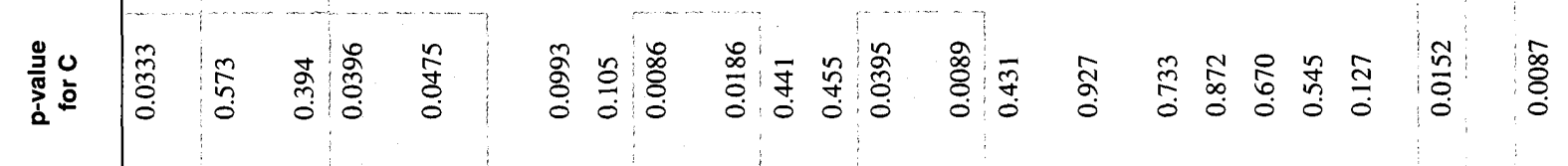

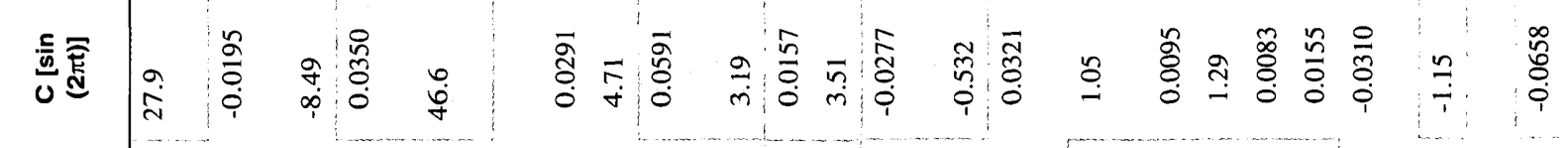

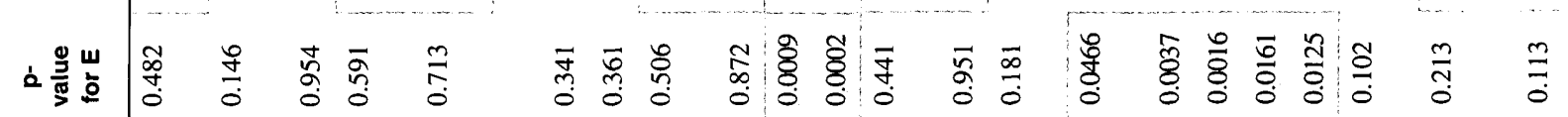

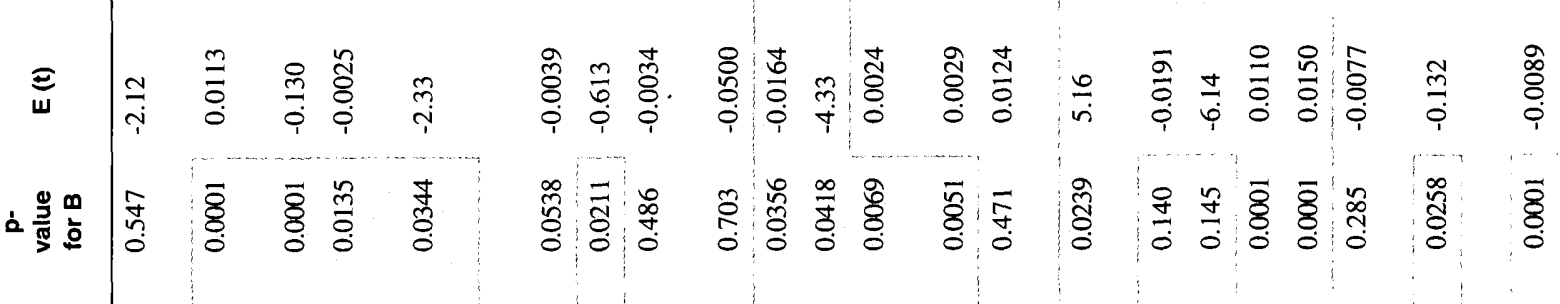

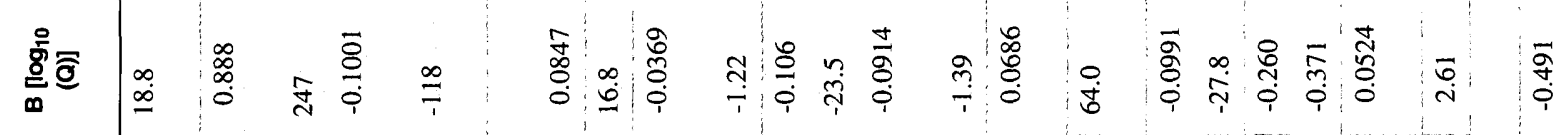

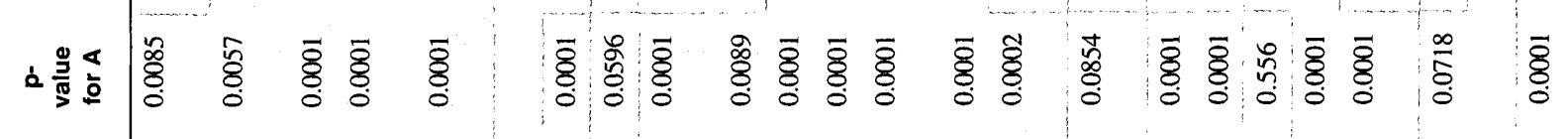

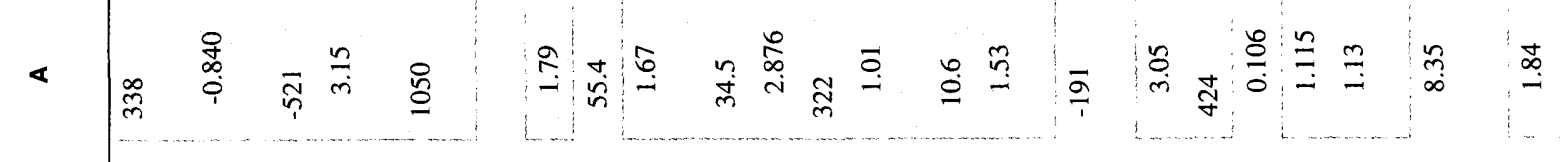

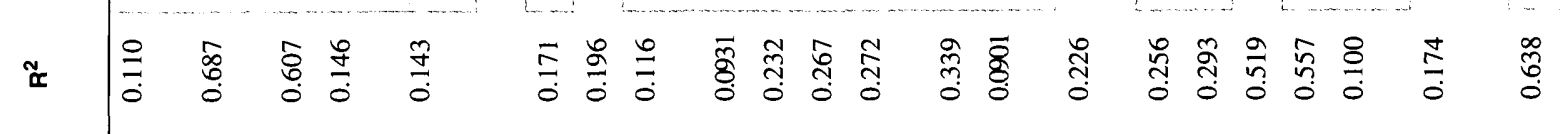

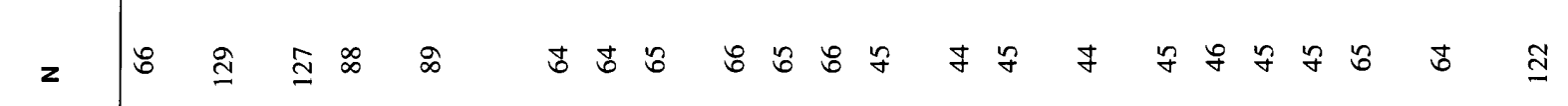




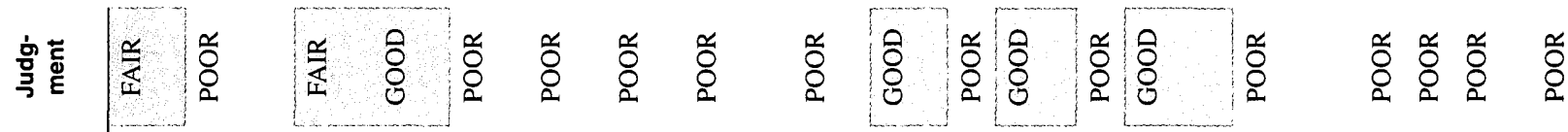

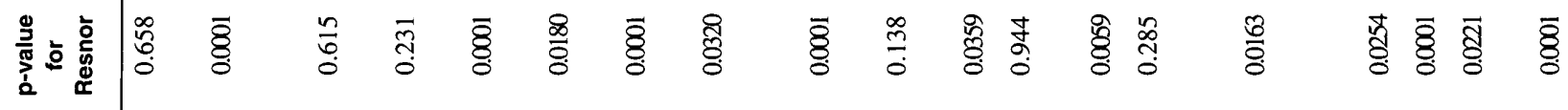

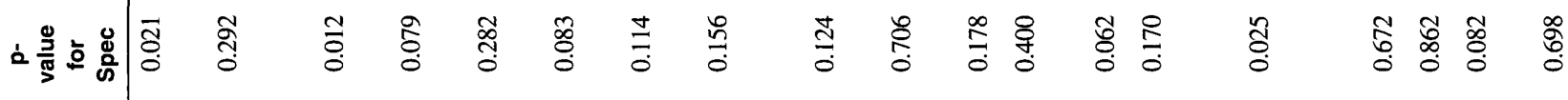

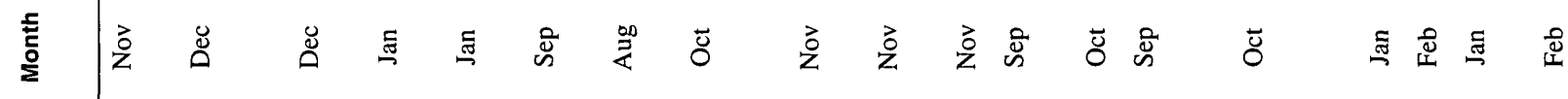

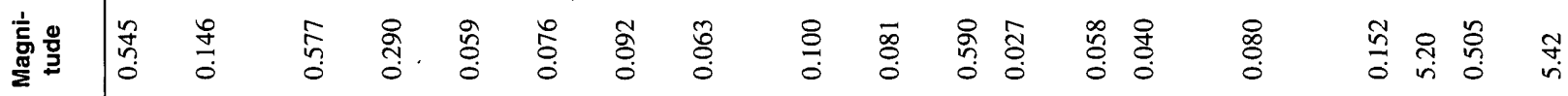

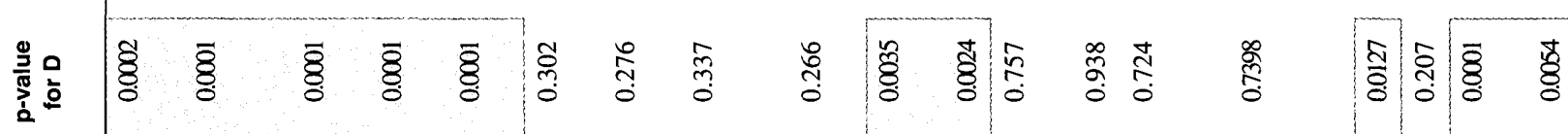

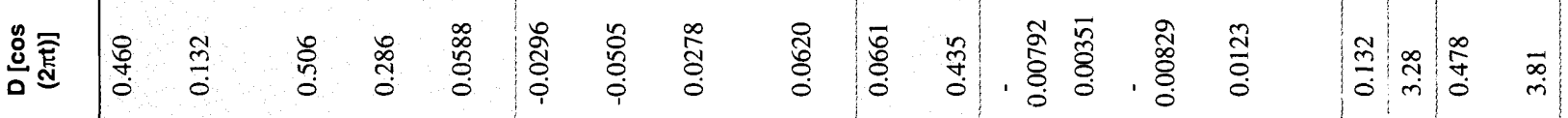

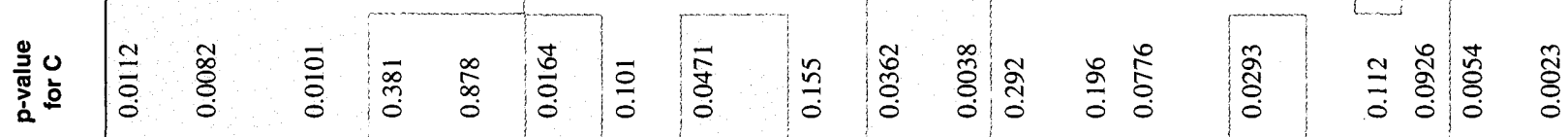

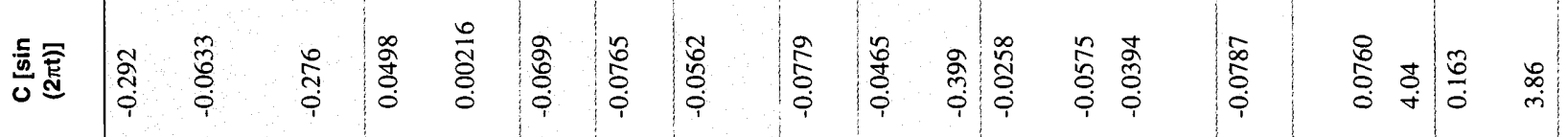

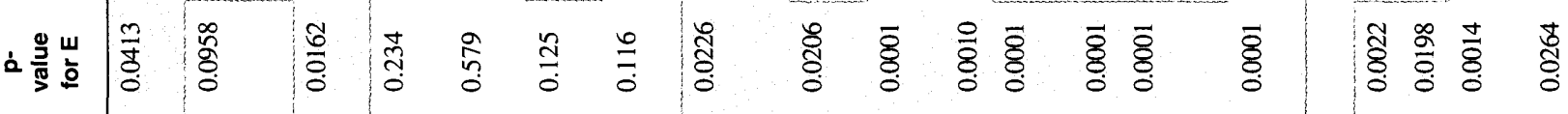

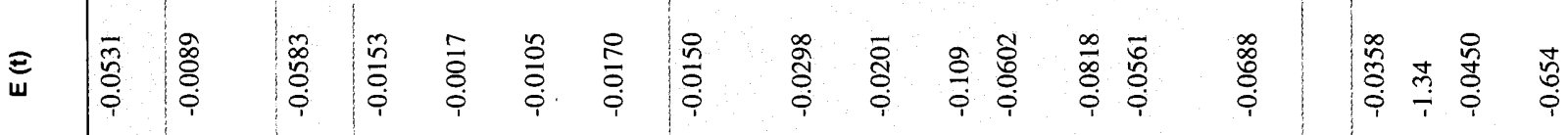

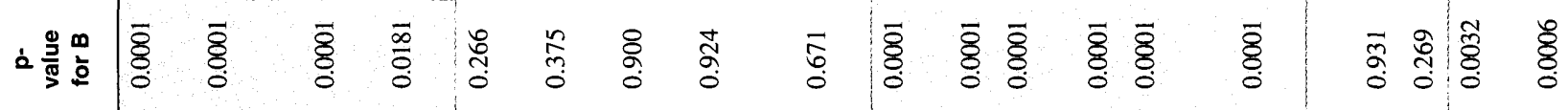

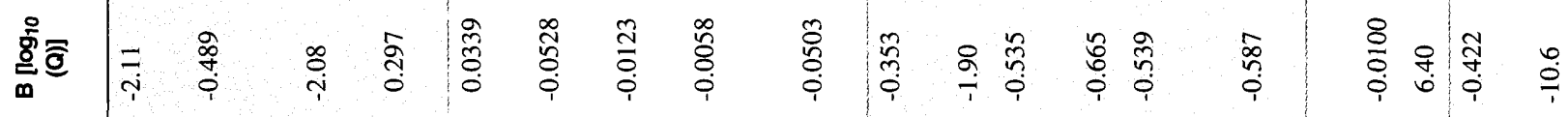

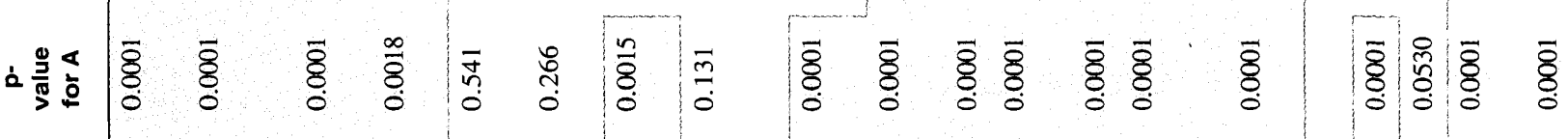

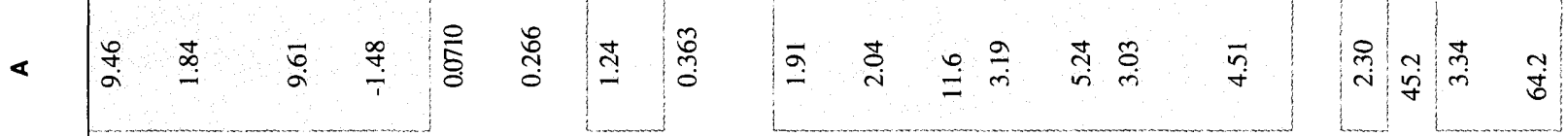

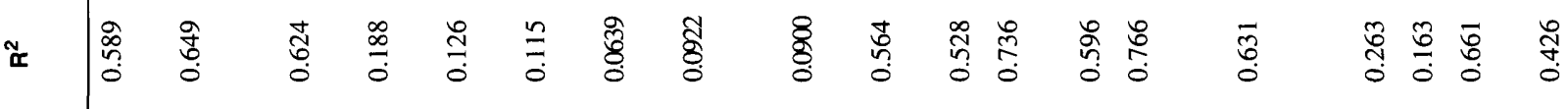

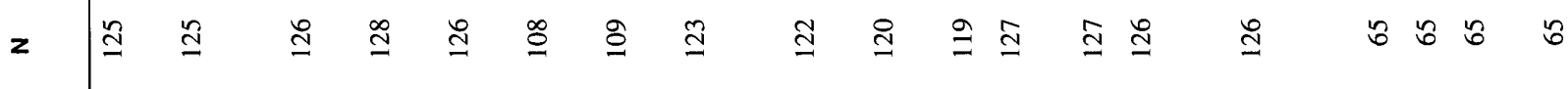

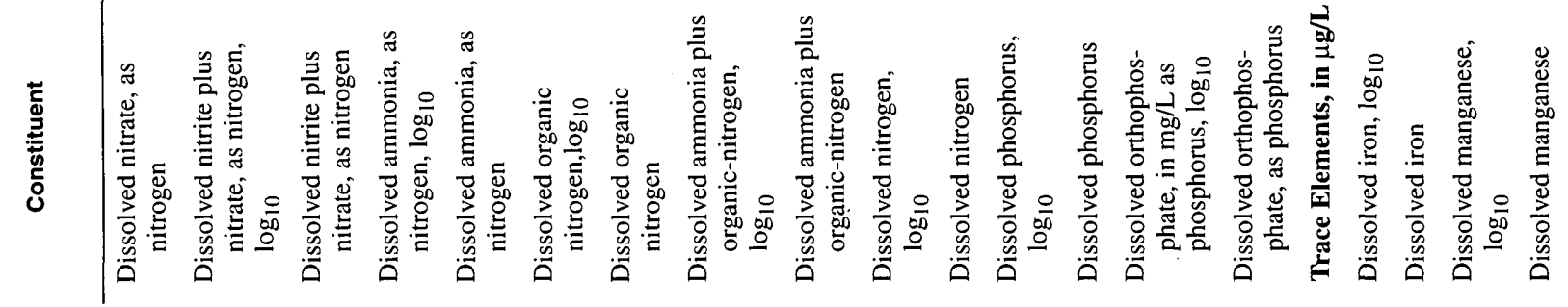




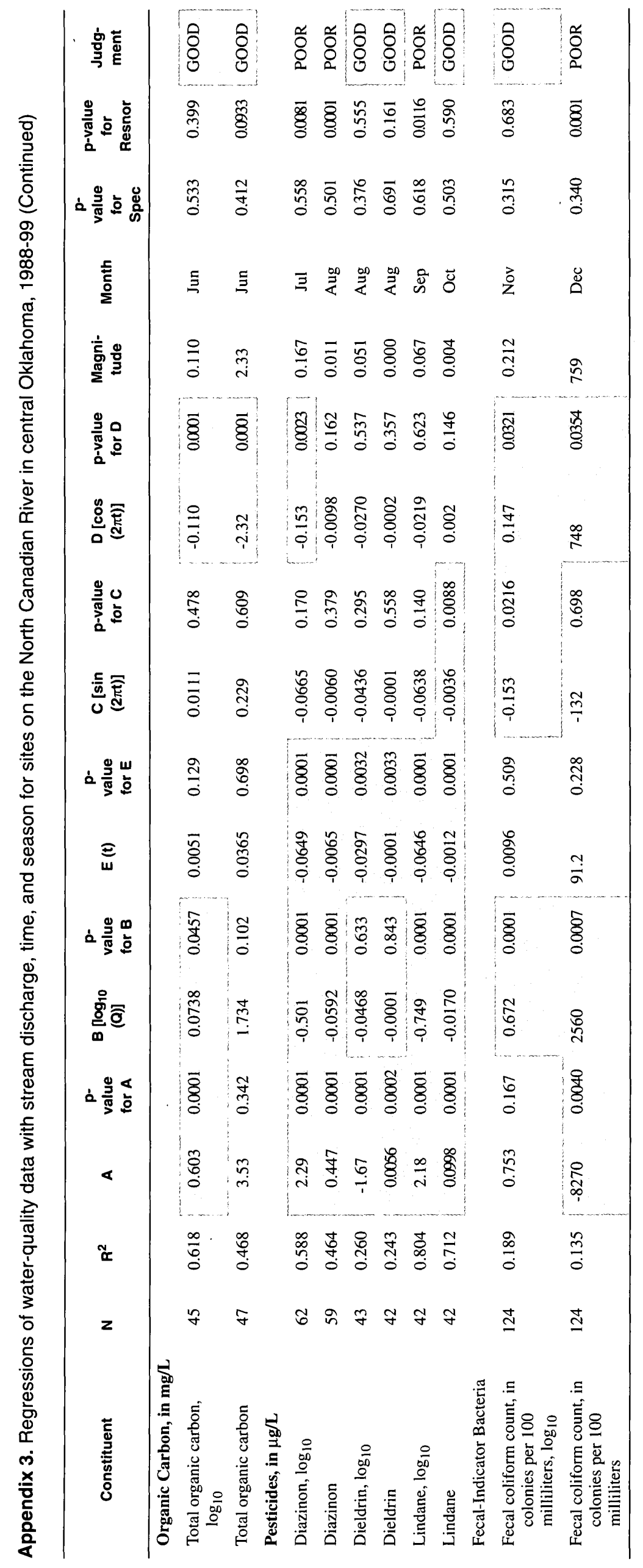

